FARM READER SERTES - FARM IIFE
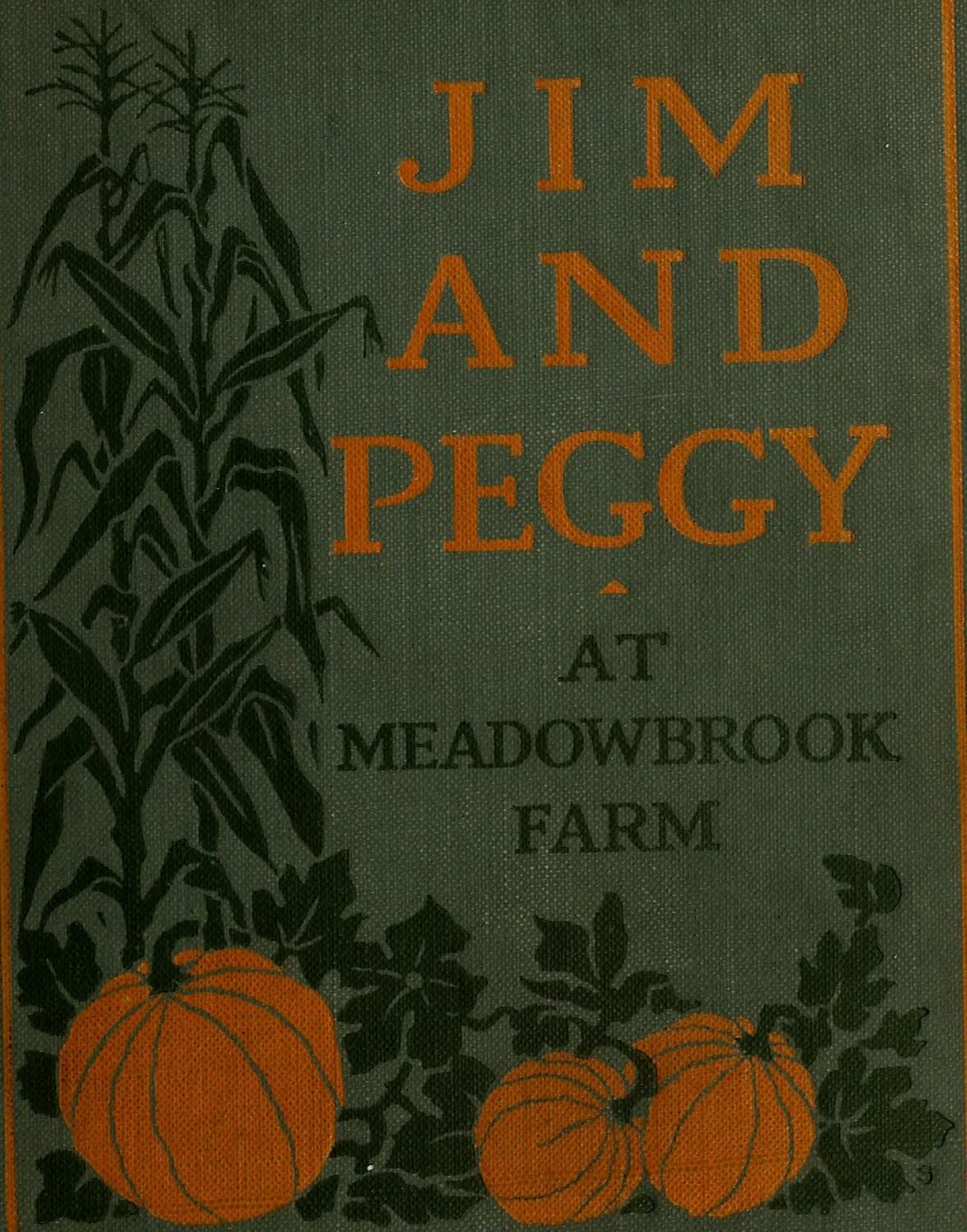

WALTER COLIINS ÓKANE 


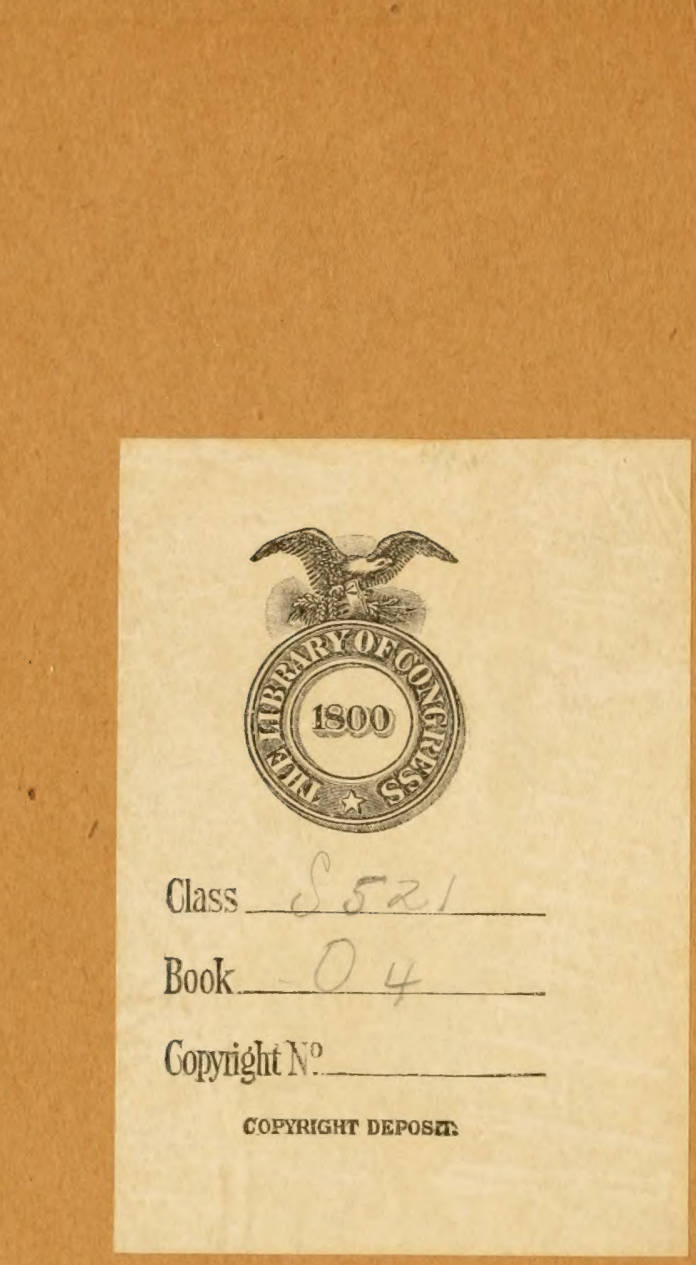






\section{1 \\ JIM AND PEGGY \\ AT MEADOWBROOK FARM}




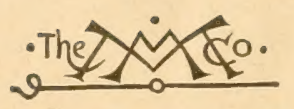

THE MACMILLAN COMPANY

NEW YORK - BOSTON - CHICAGO - DALLAS ATLANTA - SAN FRANCISCO

MACMILLAN \& CO., LimXted

LONDON - BOMBAY - CALCUTTA MELBOURNE

THE MACMILLAN CO. OF CANADA, LTD。 TORONTO 



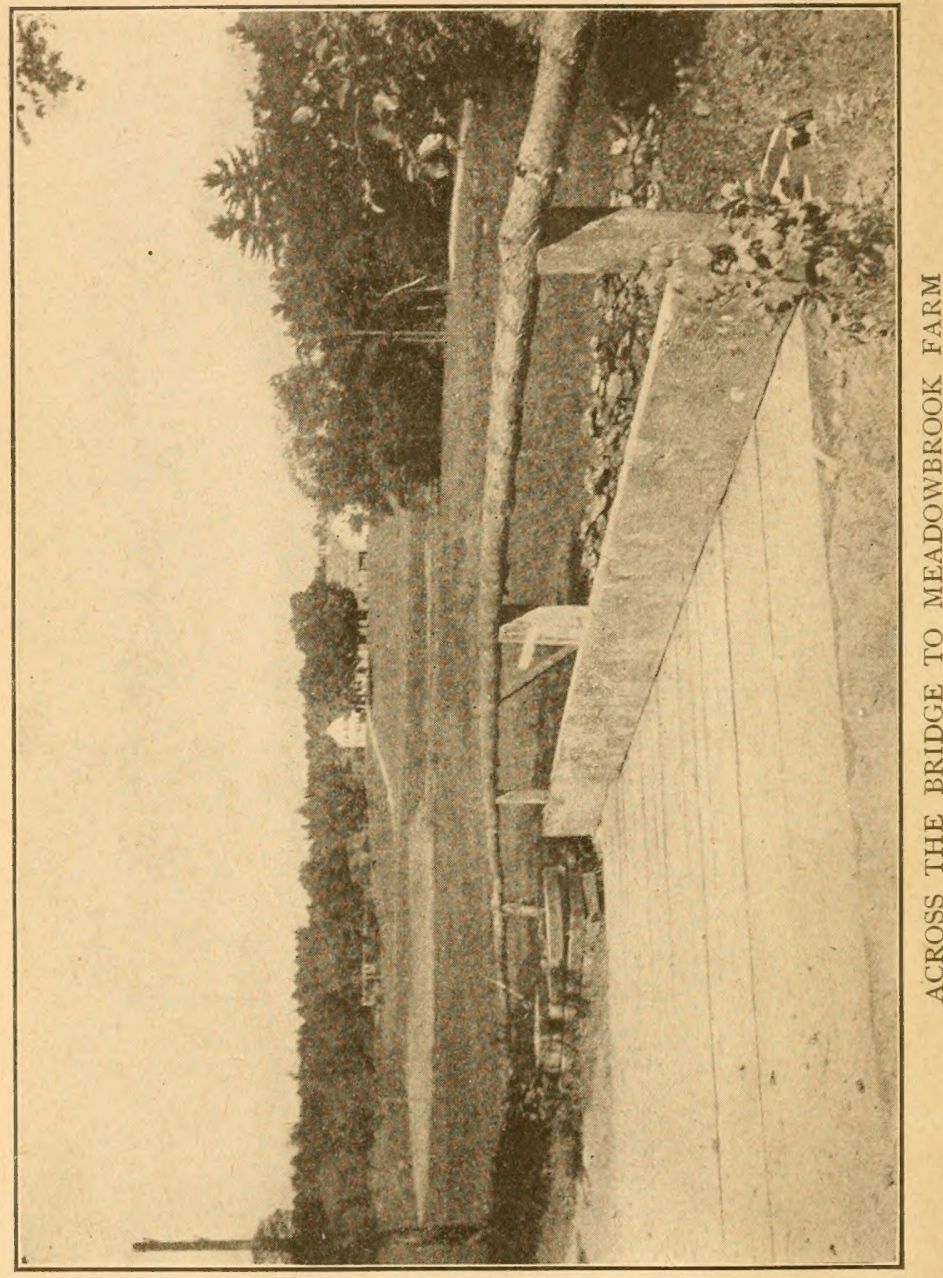


FARM READER SERIES

FARM LIFE

\title{
Jim and Peggy
}

at Meadowbrook Farm

\author{
BY \\ WALTER COLLINS O'KANE
}

WITH MANY ILLUSTRATIONS FROM PHOTOGRAPHS

Xrew 洫ark

THE MACMILLAN COMPANY

1917

All rights reserved 


\section{1 \\ .04}

\section{COPYRIGHT, 1917}

BY THE MACMILLAN COMPANY.

Set up and electrotyped. Published January, 1917

JAN 181917

(C) Cl. 4453701

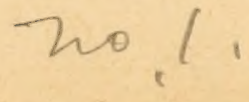




\section{PREFACE}

To convey a true picture of an everyday farm - its work, its play, the things that make up its ordinary life - is the purpose of this book.

Primarily it is written for children who are not living in the country. Its plan is to describe the fundamentals of farm life in terms that any city child will understand. That children who have at some time shared in country life, either in brief visits or in longer residence, may find the volume equally interesting, because of renewed acquaintance, seems more than possible.

The manner of presentation chosen is that of the story. This has been done for two reasons: partly because of the intrinsic appeal of a narrative and its aid in awakening and holding interest; partly to secure the desirable means thereby afforded of bringing out in unobtrusive and incidental fashion the numerous truths that the book must tell. While there are many pages of fact in the volume, it is hoped that no paragraph may appear to the reader oppressively didactic.

The subject matter emphasizes the fundamentals of farm life: what the rain, the sun, roads, fields, distance, fences, neighbors mean in the country. These things 
have, in truth, unguessed values on the farm, as compared with their usual part in city life.

Consider water supply. To the city child water means, usually, the turning of a faucet. In the country? Think of all that water means there - springs, wells, pumps, windmills, gasoline engines, pipes, tanks; and following these a train of closely related topics, from the weather to fire protection.

Sunshine and fair weather. Sources of pleasure, indeed, in the city. But on a farm? There, frequently, the whole plan of work and play, the entire ordering of a week's program, must turn on this elemental essential.

An earnest endeavor has been made to describe graphically and simply the typical major duties of the ordinary farm - plowing and harrowing, seeding, cultivating, the care of live stock, haymaking, milking, butter making, the fuel supply, harvesting, the way in which a general farm provides its table supplies and the manner in which these are stored for winter use.

Thought and space have been given, also, to the more personal, intimate things that come most closely home to the daily life of farm children - the chores, both those that the boy is heir to and those that fall to the lot of the girl; the playtimes and pleasures that children of a farm enjoy; the country school. The story takes its characters through the round of the seasons, from fall to summer, touching the typical activities of each. 


\section{An. Outline for Teachers}

The questions sometimes printed at the close of each chapter in supplementary readers have been omitted from this volume. In place of these a separate booklet has been prepared for the teacher's use.

In this booklet are included suggestions for further discussion on the part of teacher or pupil, and topics that the pupil may look up.

The booklet is available to any who wish to use it in connection with this book.

\section{Acknowledgments}

The author is indebted to Dr. A. E. Richards for helpful reading and criticism of manuscript.

Most of the illustrations are original. For other photographs acknowledgments are due Mr. Bernard Raymund, Miss Flora McCoy, and the International Harvester Company.

To those who in this book have become certain principal characters, especially to Jim, and Peggy, and to Jane, the author acknowledges his grateful debt of obligation for their unfailing inspiration and their patient help. 



\section{CONTENTS}

Chapter I. The Road From Milford.

The level stretch - A turnout - Four corners - The signboards - Old Joe - Down the hill - Across the meadow The farm.

Chapter 1I. Jim and Peggy .

Horace and Jane-The colts - Brownie and Jerry Where Jim and Peggy live - Belinda - Living in the city Turkeys and ducks.

Chapter III. Uncle David's Plan

To see what a farm is like - What Horace and Jane are to do - Harnessing Dan and Ben - The letter - Jim and Peggy arrive - The drive home.

Chapter IV. The First Morning

Jim wakes up late - Out to the back field - Plowed ground - How the riding plow worked - The cutaway harrow - A walking plow.

Chapter V. The Pigs and Susan . . . .

The little pigs - Carrots - The big pig - Spot and Tag The brown and white calf-Feeding Susan.

\section{Chapter Vi. Apples}

The Grimes tree - Which to eat - Filling barrels - Gathering fallen fruit - Rabbit guards - A tree propped up The basin of hot water.

Chapter VII. Eli and Aaron

Up early - Feeding sugar to Billy and Queen - The steers - Jim climbs up on Eli's back - Two mallard ducks. 
CHAPTER VIII. CHORES ..+47

In the barn - The haymow - Horse stalls - The grain harrels - Feeding Dan. Ben, and Milly - Where the cows are kept - Skim milk and ground feed for the pigs.

Chapter IX. Peggy's Pies . . . . . . . 53

The breakfast dishes - Washing napkins - Getting the pumpkin ready - Making piecrust - Lining the pans - The filling - Baking.

Chapter $X$. CORN

The knives - A new silo - What is ensilage? - The ensilage cutter - Harvesting ensilage corn - Cutting ear corn Making the shocks - The squirrel's breakfast table.

Chapter XI. MilK and Cream

The milk pail - How Uncle I)avid milked - What Belinda did - Milk for Peter - The spring box — Where the milk goes - The separator - Cream in one can, skim milk in the other.

Chapter Xil. How Aunt Lucy Made Butter .

A rainy morning - Jim and Horace - How the cream was churned - Washing out the buttermilk - The butter worker -Working in the salt - Making the prints.

Chapter XIII. IN THE BARN .

Shooting with the sling shots-Corn for ammunitionFeeding turkeys - Surprising Peter - The corn rhymeDriving Eli and Aaron - Digging bait.

Chapter XIV. The Fishing Trip

Getting hooks and lines ready - Through a back pasture - Chased down a hill-Barbed wire - The old mill Shiners - The new place - Back home.

Chapter XV. ON The WAY to Freeport .

The peddler's wagon - Drilling a well - Gasoline pump Windmill - Each farm must have its own water supply What the weather means - A round barn - The meat wagon - A good farm. 


\section{CONTENTS}

Chapter XVI. The Woodpile

Uncle David's customers - A load of cordwood - Where the cordwood came from-A bucksaw - Why wood is used - A gasoline engine saw.

Chapter XVII. The Drive Home 106

Old Tom's tool box - Fitting a shoe - Inside the shop The forge - Lunch - The well - A bucket on a chain - The big water tank - Fire protection on a farm.

Chapter XVIII. A Visit to the Reynolds Farm .

Work finished early - Milkweed seeds for letters - Sumac and wild asters - Andy's cow - Sammy's chickens - The colt - Moses the drake - Goldenrod.

Chapter XIX. Sunday Morning . . . . .

The spring - How the brook pumped the water to the house - Andy and Milly - Jim on Milly's back - Where the horses were hitched.

Chapter XX. Good Roads and Back Roads . .

Last day before school - The mail box - How the mail comes to the farm - A graveled road - The county lineThe washed-out hill — The soap kettles — Sand - The grassy road - Mud.

Chapter XXI. School . . . . . . . . 134

Spot and the boys - Only one room - Play - The inside of the schoolroom - Recitations - Few in each grade - The stick with three prongs - A rainstorm - Muddy roads and wet grass.

\section{Chapter XXII. Winter Supplies}

Jim and Peggy cut across through the woods - Digging potatoes - The root cellar - How the vegetables were stored - Squashes - Bean vines - Threshing out the beans What a farm buys and what it raises. 
Chapter XXIII. WOODChUCKS AND CORN

The "chucks" and Spot - Fresh holes - Andy husking corn - Horace and Jim help - Where the corn was stored - The letter from home - Peggy and Jim go back to the city.

Chapter XXIV. The Road in Winter

Plans for a winter visit - Snow - Runners on the wagon Jim and Peggy arrive - The village street - A snowplow Over the hill.

Chapter XXV. A Winter Morning

The snow blanket - Paths - The barn - The cows Gathering eggs - Not many now - Rabbit tracks - Along the brook - Spot and the pile of rocks.

Chapter XXVI. The ICE Harvest 167

Where the ice was cut - The rows of squares - Sawing Breaking off the long row - Loading cakes into a sled Building a fire - Why each one helps at the work - Back to the city.

Chapter XXVII. Spring

In the fields - Birds - Speckle - Cows out again - Plowing the garden - Jane's flowers - Busy days - Getting after the weeds.

Chapter XXVili. Planting-Time 178

Rainstorms and plowing - Harrowing - The spike tooth -Clods in a wet place-A plank drag - Planting corn The drill - Rolling after seeding.

Chapter XXIX. UnCle John and Jim. 184

School closed - Plans for the spring visit - Jim and Peggy arrive with Uncle John and Aunt Emily - Looking the farm over - The horses - A new Holstein - Clover.

Chapter XXX. Across the Fieldo

A set of bars - Uncle John's old home - Stump fences Putting up a wire fence - Gates - Down to the old dam. 
PAGE

Chapter XXXI. Aunt Emily and Peggy . . . . 196

Hunting up the farm pets - How pigs grow - Houses for little chicks - Hiram performs - The calves - Fresh vegetables - Aunt Lucy asks Peggy.

Chapter XXXII. Old AND NEW . . . . . . 203

A new kind of light - How the gas was made-Electric lighting ontfits - The lantern and the oil lamps - Improvements - Harvesting time - Uncle John asks Jim.

Chapter XXXIII. Haymaking . . . . . . 210

The mowing machine - How the grass was cut - Uncle John and Aunt Emily come back from a walk - Another trip to Freeport - The overhead carrier - A hay baler.

Chapter XXXIV. The FARM . . . . . . 217

The hay tedder at work - The hayrack - Raking - Cocking up - Loading the rack - Into the barn - The trip up the hill - The new farm. 



\title{
JIM AND PEGGY A'T MEADOW- BROOK FARM
}

\author{
CHAPTER I \\ THE ROAD FROM MILFORD
}

If you drive out of the village of Milford by the road that goes by Old Tom's blacksmith shop, you

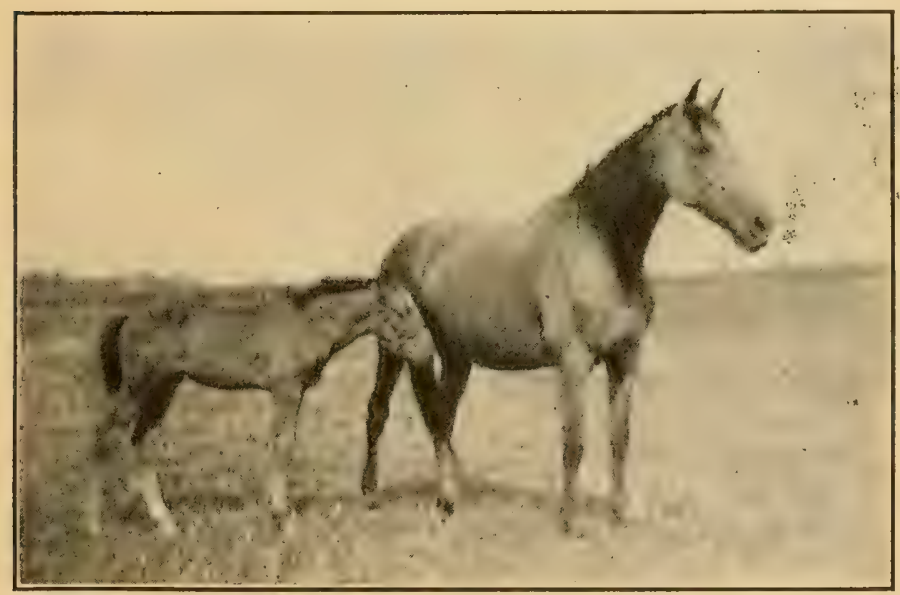

Becky and Her Colt Come to the Fence to Watch You come right away to the top of a steep little hill. It's only a short way down, but big Dan has to 


\section{JIM AND PEGGY AT MEADOWVROOK}

hold back tight in the harness, walking sort o' sidewise, to keep the wagon from running over him.

Just at the bottom the road divides. You'll need to remember there to take the left-hand fork,

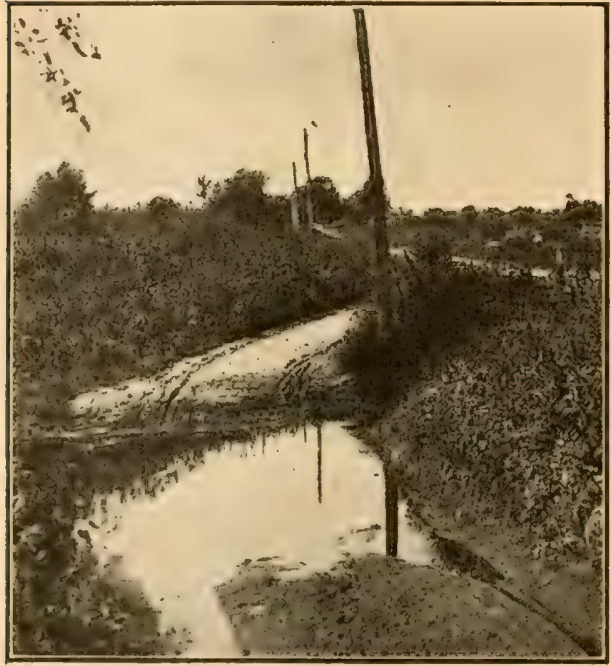

A Turnout Leads Down Through the Water if you're going with us.

For a long while, then, you jog along on a level road, with wide fields on e a c h s i d e stretching away almost as far as you can see. In summer it's often hot there and the dust rises beneath the horses' feet, giving the wagon, and you, too, a coat of white. In winter the frosty wind swoops down and tries to nip your nose and your ears. Over on the right, in one of the fields, George Turner's bay mare Becky and her new colt come galloping to the fence. Becky stands with her ears pointed forward, watching you and Old Dan and the wagon. But the funny colt is not sure about you and sticks close to his mother. 
After a little, a brook crosses under the road. A turnout leads down through the water and back to the highway again, so that you can drive into the brook and wash some of the dirt from the wheels.

When you've passed five or six farmhouses you come to a crossroads, where one way leads square to the left, another square to the right, and the road you're on goes straight ahead. There isn't any signboard there. But you'll know the place because there'll be a dog-house in the farmyard at the corner; and Benny Wheeler's sleepy, good-natured old Champ will be sure

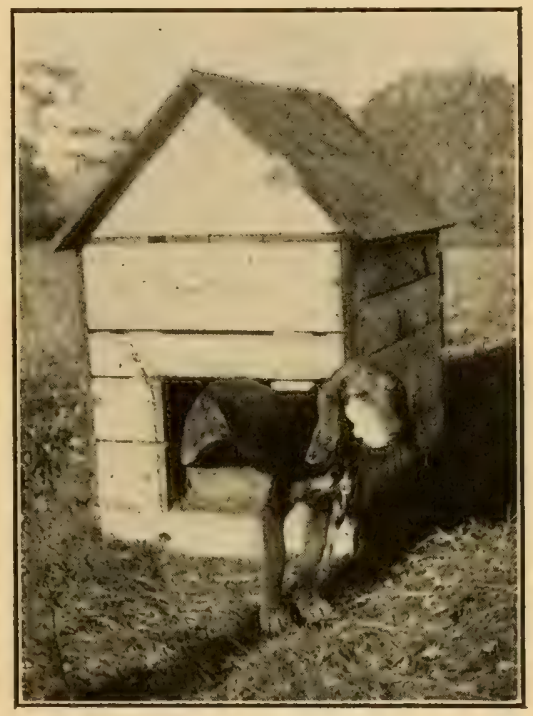

Old Champ Comes out to Greet You to come slowly out to wag his stubby tail at you. You'll take the road to the right. By and by it will lead you under some big trees and across a little bridge over another brook - only it's not really another but is the same one that you saw before at the turnout. There's a marshy 


\section{JIM AND PEGGY AT MEADOWBROOK}

spot close to the bridge, and often, in summer, cows stand there in the cool water, turning their heads slowly to watch you go by. In the evening big, old bullfrogs boom

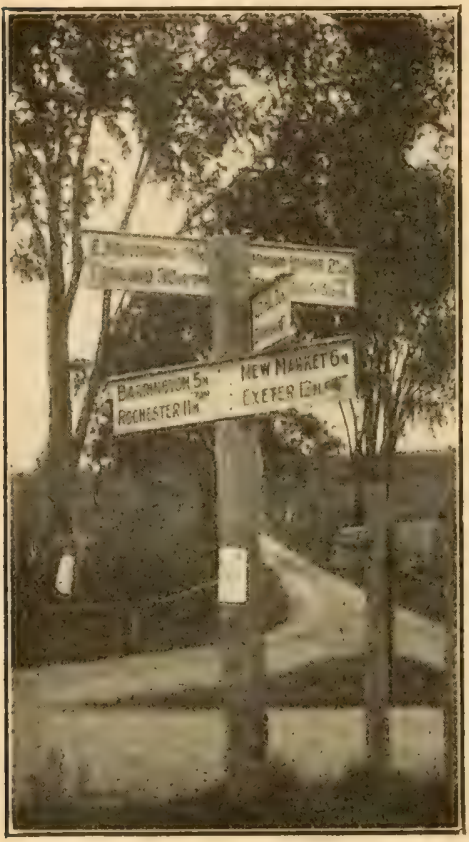

There's a Sign-Post at the Corner away among the waterweeds.

You drive on, up a gentle slope, and after a time come out at another corner where there are four highways spreading out ahead of you, each leading in a different direction. There's a signpost at the corner, with white-painted boards pointing crisscross up here and down there; and close by is a schoolhouse, with a flag-pole in front. One of the signboards says "Sawyer Mills" and points to a road that swings round the side of the schoolhouse and climbs a hill a little farther on. That is the road you'll take.

You can be sure you're on the right way because soon you'll pass a farm with a high board fence between you and the barn. If you shout or 
whistle, you'll more than likely see a pair of short horns and a big head and a black nose with a ring in it come up over the top board, and perhaps old Joe will rumble at you.

It's a pretty good climb to the top of the hill, though it's not steep except at the very last. But just as soon as you reach the top, down goes the road again, curving away to the left, and then to the right, with bushes and woods on each side of it, so that

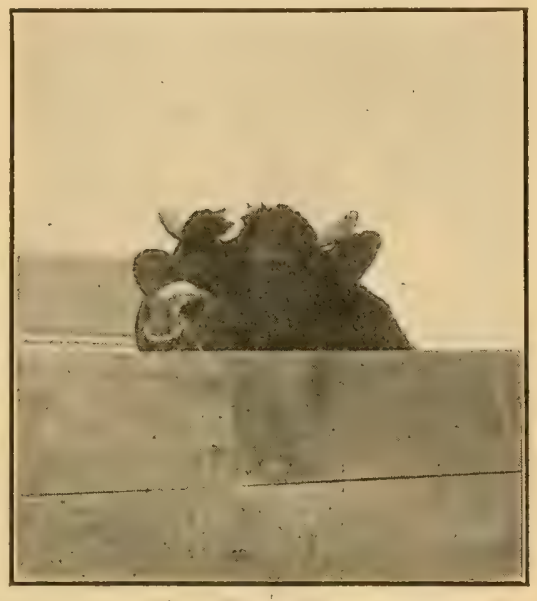

You'll SeE Joé Looking Over the TOP BOARD

you can see only a little of what is coming.

After a time you can see a wooden bridge ahead of you, around a bend. Big Dan holds back all he can, for the road is steep and there are loose stones in it where the rain has washed down. In a moment the wagon rattles on the planks of the bridge. All at once you look across a meadow to the right, and see a.white farmhouse on a knoll, beneath big, spreading trees, with a lane leading up to it from your road.

Old Dan begins to hurry. A black and white 


\section{JIM AND PEGGY AT MEADOWBROOK}

dog hears you cross the bridge, catches sight of Dan, and comes tearing across the field. Some one in a white apron comes out on the porch of the house. A boy and a girl race down the lane to meet you.

You have come to Meadowbrook Farm.

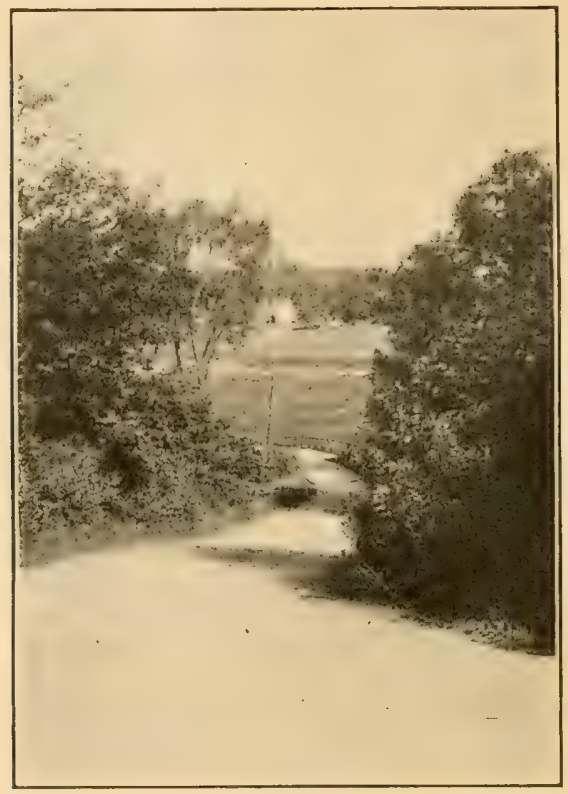

Down Goes the Road to the Bridge 


\section{CHAPTER II \\ JIM AND PEGGY}

Uncle David North pushed back his chair from the breakfast table and looked across at his son Horace.

"Horace," he said, "how old are you ?"

Uncle David was always asking that. Horace grinned.

"You know, dad," he said.

"What is it, — ten?"

"No, twelve."

Horace's sister, Jane, came in from the summer kitchen.

"Then Jane must be twelve, too," said Uncle David, as if to himself.

"Daddy, you know I'm thirteen," put in Jane.

Uncle David looked at the children's mother, Aunt Lucy, who was busy at the stove and had her back to them.

"Do you think you youngsters could show two visitors over Meadowbrook Farm? - Now wait. I mean really show them all about the place, so that they'd know just how we live here."

Aunt Lucy turned to look at him wonderingly. 


\section{JIM AND PEGGY AT MEADOWBROOK}

Horace and Jane slowly nodded their heads, wondering, too.

"All right," said Uncle David, "skip out, both of you and look after the colts and chickens, while I talk with your mother."

When they had gone Uncle David walked over and stood by a window.

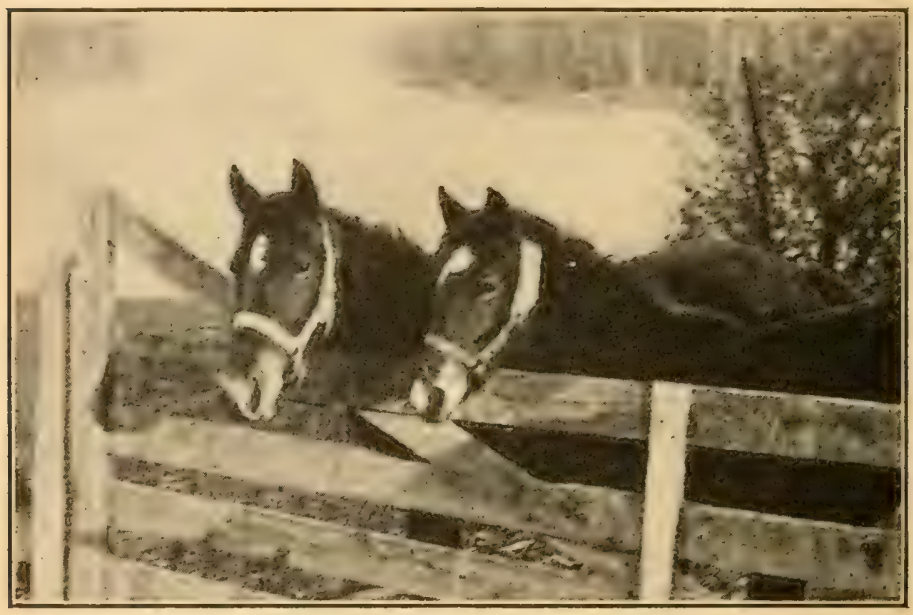

The Colts Came. Back to the Gate to Watch Horace

Out in the yard Horace led the colts out of the barn, opened the gate to the pasture lane, and turned them loose on the other side. For a moment they danced around, first on their hind feet with their front legs up, then on their front feet with their hind legs up. Horace latched the gate and walked away. At once they came and looked 


\section{JIM AND PEGGY}

over, to watch him. Jane stopped to pet Peter the cat, and then heard Brownie and Jerry, the duck and drake, quacking for her, and went over to let them out of their coop for the day.

Aunt Lucy left her work at the stove and sat down at the deserted table.

"What is it about the visitors, Father?" she said.

"Well, Mother, it's about Jim and Peggy Harlow : you know - John and Emily Harlow's children."

"You mean your cousin John, in the city ?"

"Yes, — though he's not really a cousin. But he and I played together

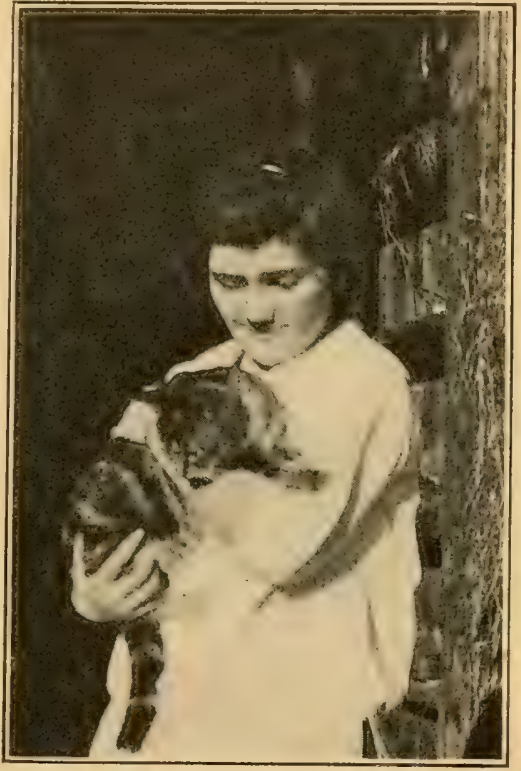

Jane Stopped to Pet Peter

when we were kids. I think he was nine or ten when his dad moved to the city to live. He's never been back."

"Does he want to come to see us?"

"No, that isn't it. He's sick and couldn't come. In fact he must go to a hospital, if he and 
his wife can find a way of caring for the children for a little. Aunt Sue telephoned about it this morning. It's the children, Jim and Peggy, I was thinking about. They're just a little younger

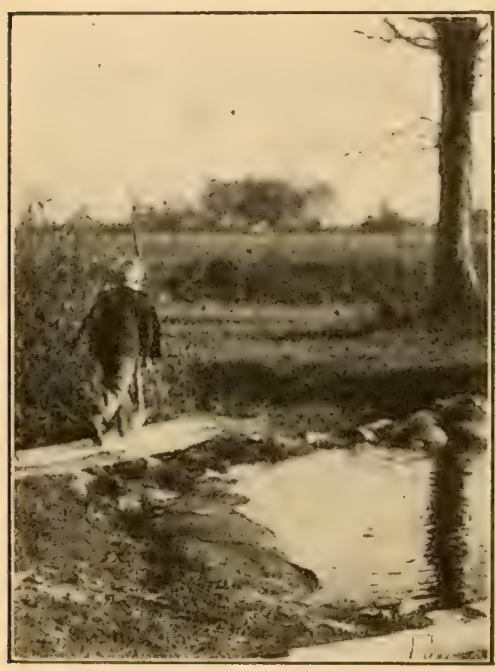

Horice Racen Across the FootBRIDGE than our children. They've never been out of the city."

"Are they sick, too, David ?" .

"No, not as I understand it. But they've never had anything but city" -

A shout," Hie, there," sounded from outdoors, and Horace came into view racing down across the meadow to the footbridge near the spring. Beyond the brook, Belinda, the new Jersey cow, had found a hole somewhere in the fence, and was getting ready to eat up the turnip patch. Jane heard Horace shout and came running to help. Together they tried to make Belinda go back through the hole. But she wouldn't look at it, and only galloped up and down the fence, first this way and then that. Finally Horace let down the bars where the pasture fence comes up near the 
end of the cart-bridge over the brook, and he and Jane persuaded foolish Belinda to go through. They fixed up the hole where she had found her. way out, and came back to the farmyard.

On the way they decided that Tony, the spotted calf, needed fresh grass to graze upon. So they pulled up the stake that Tony's rope was tied to, led him over to a new place near the old windmill,

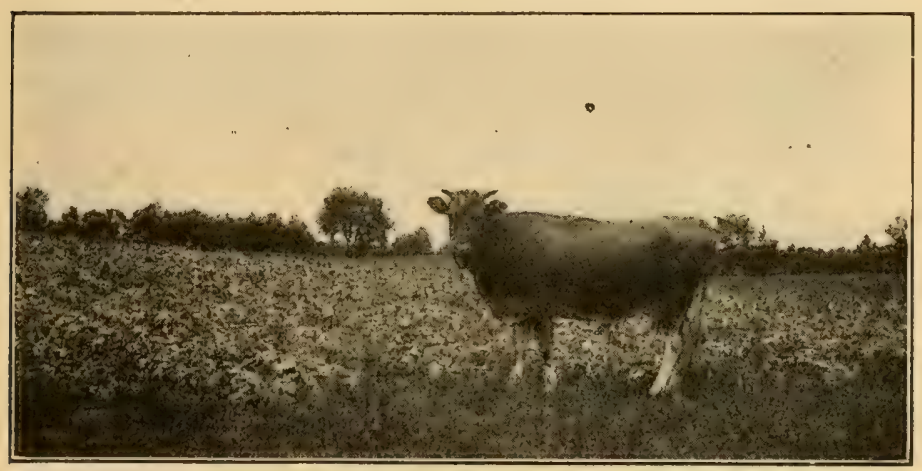

Belinda Was in the Turnip Patch

and pounded the stake into the ground with a stone. Then they stopped to talk to him, and watch him wiggle his ears.

"It's this way," continued Uncle David. "For years, you know, John and Emily have thought of coming back to the country. But they've got so far away from it that it seems a big thing to undertake. And then they've a notion that the children, Jim and Peggy, might not be contented or get 


\section{I2 JIM AND PEGGY AT MEADOWBROOK}

along all right. Aunt Sue says that Emily Harlow wrote her that they'd pack up and move to-morrow if they were sure about the youngsters."

Aunt Lucy nodded.

"So you thought we might give the children a

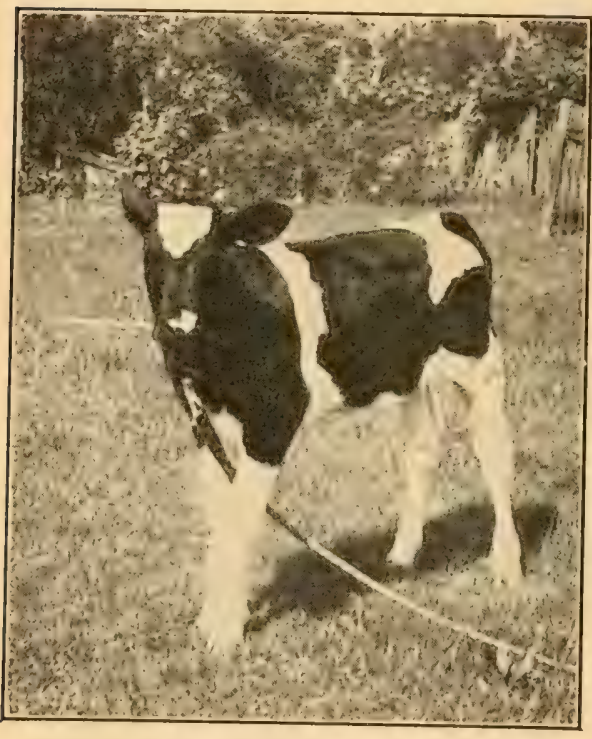

They Watched Tony Wiggle His Ears taste of it here at Meadowbrook, and see how, they like it ?" she said. Then she added "That would mean that they would decide the whole matter, wouldn't it ?"

"Yes, I guess that's about it," said Uncle David.

Through the window they watched Jane come out of the barn door carrying a bucket of grain. She stopped to speak to old Speckle and her little chicks in their wire cage. Then she walked over toward the wagon shed, to call big Gobbo, the turkey gobbler, and his flock. In a moment five or six of the turkeys were around her, while Gobbo 


\section{JIM AND PEGGY}

spread his tail feathers and marched back and forth, drooping his wings and making funny noises in his throat. Soon there was a quack-quacking, and half-

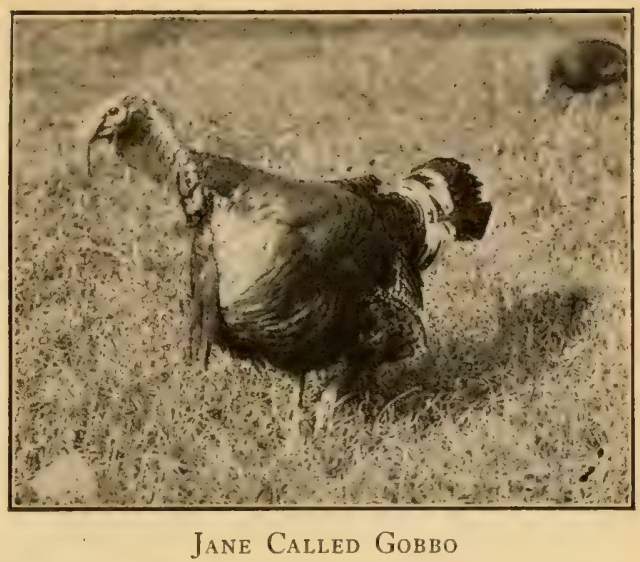
a-dozen ducks the breakfast.

"I'd be glad to have them come, David," said Aunt Lucy. "Shall we tell Jane and Horace all about it?" 


\section{CHAPTER III \\ UNCLE DAVID'S PLAN}

"Well," said Uncle David, "my plan would be this. We'd want Jim and Peggy to see just what

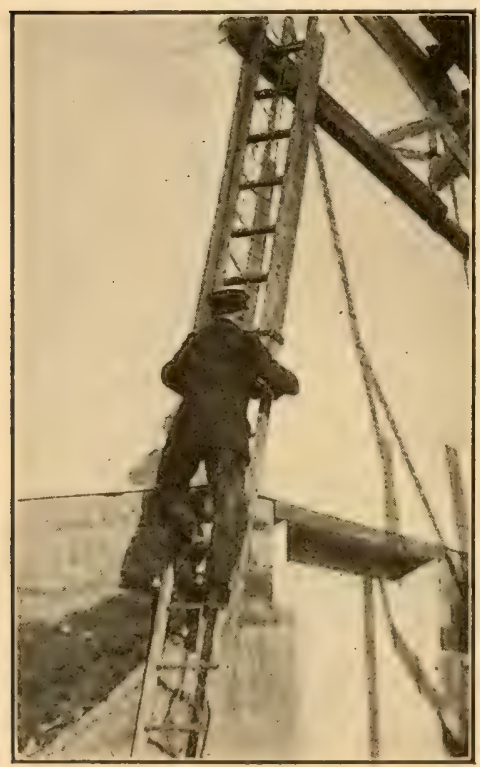

ANDY Was at WORK ON THE Barn our life here is like. We don't want them to have all play, and think that there isn't any hard work on a farm, or that it's all sunshine or all rain. Of course we won't say to them that their father and mother are going to let them decide whether to move to the country or not. Maybe that isn't so, anyhow. We'll just give them all the real farm life we can."

"As for Jane and Horace, and the part that they can take"

Just then the door to the summer kitchen opened and Horace stuck his head in - 
"Dad," he said, "do you want Andy to paint the gutter pipe on the barn ?"

"Did he want to know?" asked Uncle David. "Well - no," said Horace.

Uncle David laughed. "He knows about it," he said.

Horace wanted to linger. But he couldn't

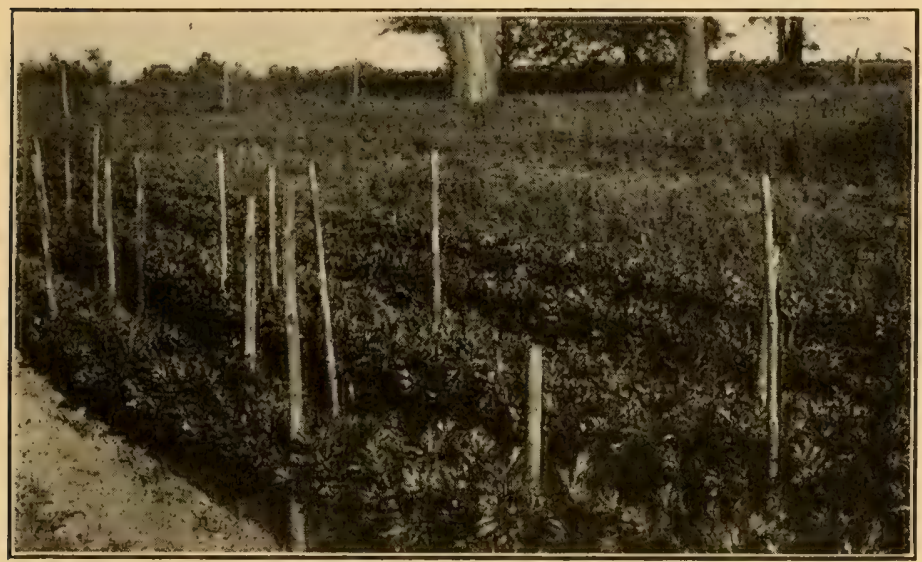

Horace Was Banking up the Celery

think of anything else to say, so he shut the door. In a moment he went by the window, dragging a board, to finish banking up celery in the garden.

"I know how we'll do it," said Aunt Lucy. "You talk with Horace and I'll talk with Jane. We'll tell them that Jim and Peggy have never been in the country, and so they must show them just how it is to live on a farm. I think it will be 
all right to say that their two visitors may some day go to live in the country, but they mustn't try to get them to like it. They must just show them all they can, and let them find out for themselves."

"That was my plan, too," said Uncle David. "But do you suppose that it's asking too much of our youngsters to keep a secret like that ?"

Aunt Lucy shook her head.

"It will be good for them," she said. "They'll do it all right."

Jane came around the corner of the house with a pail of water to fill the dishpan that Brownie and Jerry used for a bathtub. Aunt Lucy motioned for her to come in, drew her down to a chair beside her, and told her about Peggy and Jim. Uncle David put on his hat, and walked down to the garden to tell Horace.

Half an hour later Uncle David asked Horace to help hitch up the horses. They'd start at once for town with the letters to Jim and Peggy's father and mother. The mail would leave Milford at noon, that way, and be in the city the next morning, instead of waiting for Eben, the mail carrier, and his slow old horse.

Horace put the harness, on Ben and Dan, and led them out. They were to be hitched to the hayrack, for there was a tire coming loose on one of the wheels, and it could be set while in town. 
Ben waited while big Dan backed around to his place beside the wagon tongue. Then Horace spoke to Ben, holding fast to his bridle, and Ben stepped around to the other side of the tongue. Uncle David fastened the trace chains, while Horace hooked up the rest of the harness, snapped

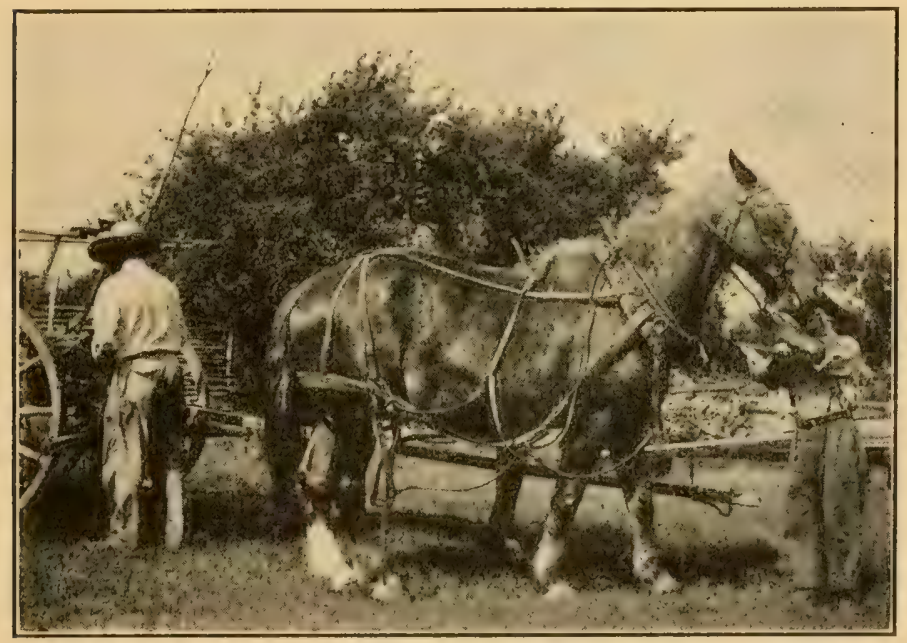

Horace Hitched up Ben and Dan

the reins in the bridle rings, and handed the loose ends to his father.

At ten o'clock they were in Milford. Horace carried the letters into the little frame postoffice and handed them in through the window.

Two days later Eben, the mail carrier, stopped his horse at Meadowbrook Farm mail box. Jane 
brought the letter to the house and Aunt Lucy read it. It said that Jim and Peggy were coming. They would arrive Tuesday evening - and this was Saturday. They could stay for perhaps two weeks, perhaps three or four, until Uncle John

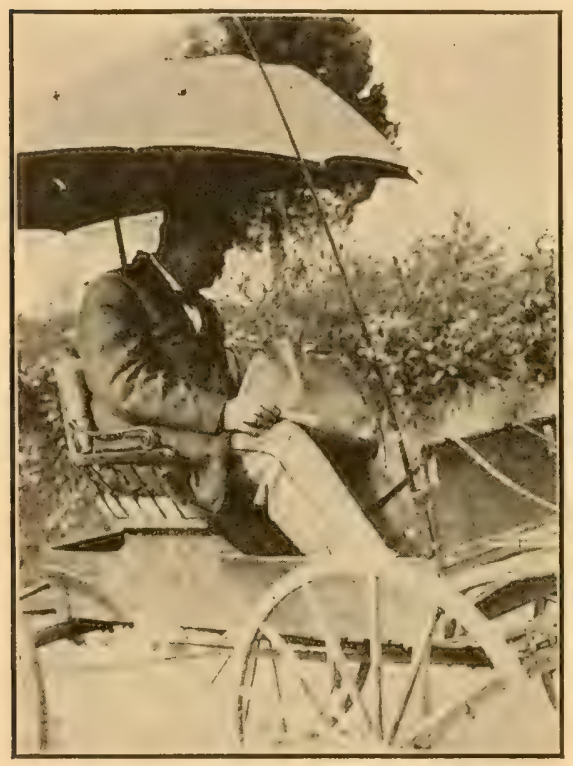

Eben Stopped at the Mail Box

was back home again.

Uncle David came in to hear the news. The last part of the letter said that the children were already in school, for it was the last of September. "Horace, when does your school start?" Uncle David asked. "A week from Monday" "Then we'll try to have them go with you and Jane, if they stay long enough. I think your teacher won't mind."

Tuesday afternoon Uncle David hitched up Milly to the surrey and drove to Milford in time for the evening train. Aunt Lucy stayed home 
to get supper, with Jane to help her. Horace had to look after the chores.

The train was late. When it arrived the sun had just gone down. Uncle David welcomed the two travelers, and stowed them away in the surrey, with a robe tucked in around them, for the night was cool. Milly trotted out at her best pace.

It was soon too dark to see much, except now and then the light in a farmhouse slipping by.

Once there was the sound of horses' feet in a field to the right. As they turned a corner at a cross-

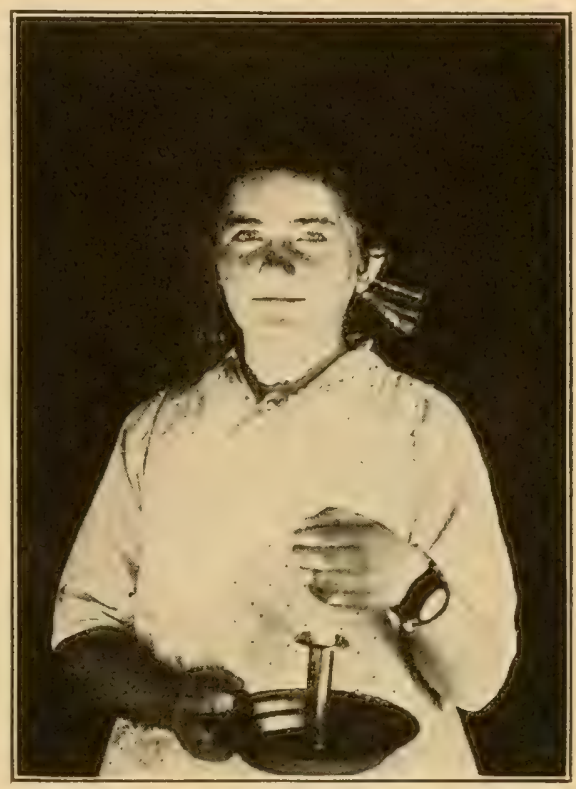

Jane Led the Way with a Candele roads a dog barked and Uncle David said, "Hello, there, Champ, how are you to-night?" After a time there were the dark forms of trees overhead, and by and by Milly slowed down to a walk and pulled steadily in the traces up a hill. Then there were woods, and Milly was holding 
back down a steep hill. In a few minutes Jim and Peggy heard a bridge rattle under Milly's hoofs, and then, almost before they knew it, Aunt Lucy was gathering them in her arms, while Horace and Jane waited to meet them.

An hour later Jane led the way with a candle, and soon both children were in bed, Jim with Horace, Peggy with Jane. The last that Jim heard was Uncle David's voice talking to Andy Wiggin about painting the barn, and the last that Peggy knew was Aunt Lucy's "Better get to sleep now, girls."

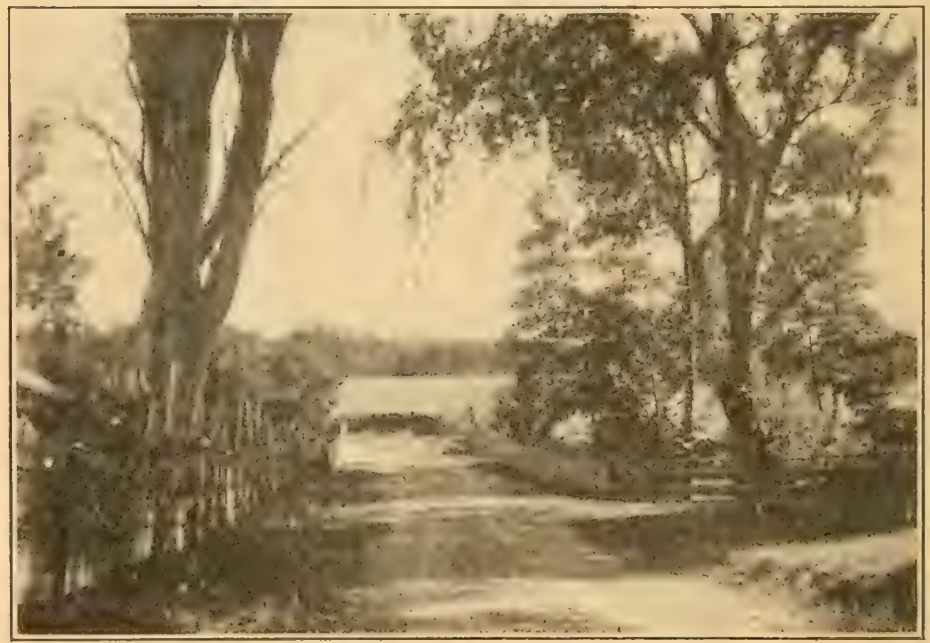

The Place where the Trees Arched Overhead 


\section{CHAPTER IV}

\section{THE FIRST MORNING}

When Jim awoke next morning it was bright daylight, and a brisk breeze was blowing in through the open window, holding the curtain straight out. For a minute Jim couldn't tell where he was. Then he remembered. He turned to look for Horace on the other pillow, but there was no one there.

He jumped out of bed. On the back of a chair were hung his clothes; rather they were not all his, for some one had hung there a pair of stout overalls, about his size. There was no sound except the noise of chickens somewhere outside. He looked out of the window and saw a flock of white hens in a yard among some fruit trees. A white rooster with them put back his head and crowed.

Wondering what time it was, and afraid he had missed part of the fun, Jim hurried into his clothes. It did not take him long to get them on. In five minutes he scurried downstairs and out into the kitchen. Jane and Peggy were there, with Aunt Lucy; but Uncle David and Horace had eaten their breakfast and gone out. Jim 


\section{JIM AND PEGGY AT MEADOWBROOK}

made up his mind that he'd not be late another time. A farm was no place to get up late. There

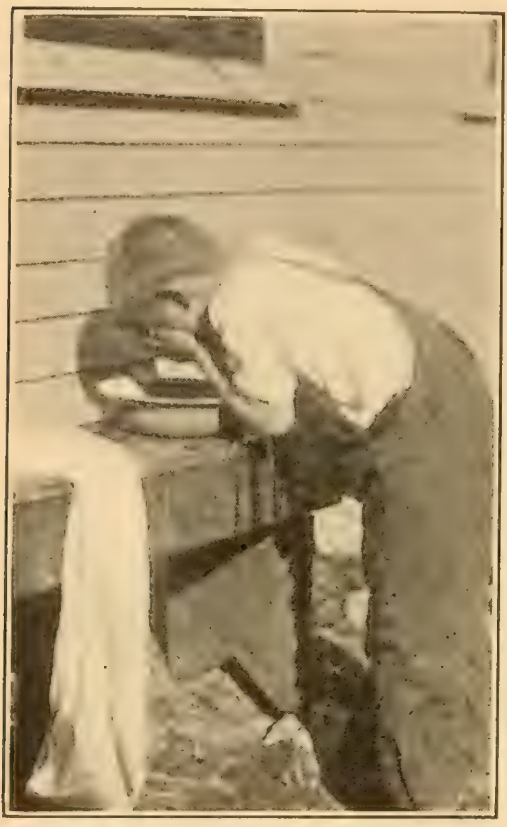

Jim WAShed his Face and Hands oúrSIDE THE Kitchen Door were too many things happening as soon as the sun came up.

Aunt Lucy sent him out to wash his face and hands in a basin on a bench outside the kitchen door. That done, he would have liked to hurry on without bothering about breakfast, but it was all ready for him. As he finished, Horace came in.

"Have you finished the chores?" asked Aunt Lucy.

Horace nodded. "Your father's plowing in the back field. Maybe Jim would like to watch him."

The two boys hustled out. They crossed the farmyard, passing a dozen things that Jim wished he could stop to look at and ask about. Climbing over a gate, they walked down a long lane, climbed another gate, and came out in a field. 
Beneath their feet was fresh, brown earth, turned up in flat rolls or waves that ran the length of the field. A little way beyond was a strip of sod like that in the lane. Along one side of this strip two horses were moving, hauling something on low, iron wheels, while a new layer of brown

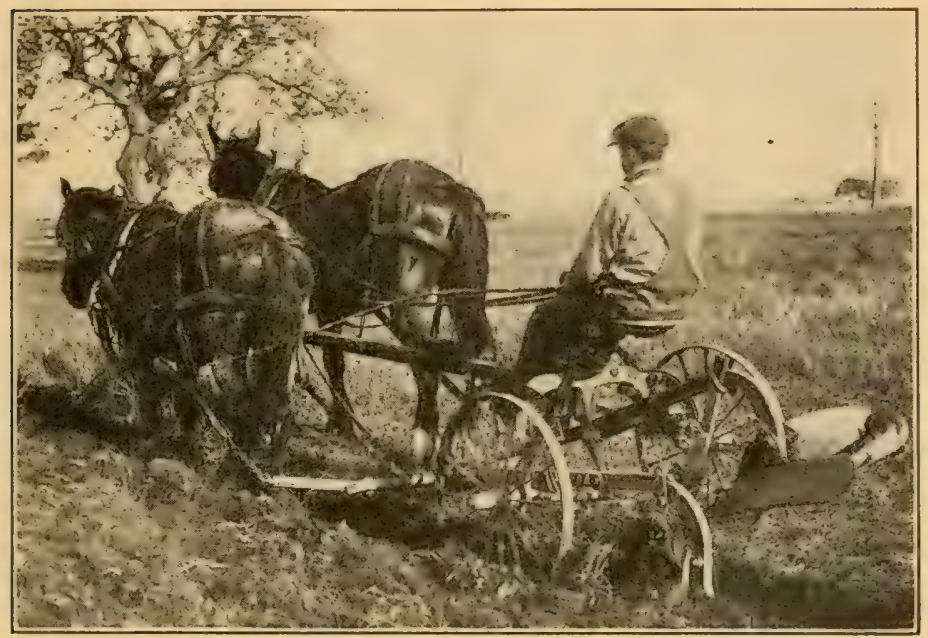

The Plow Turned up the Brown Earth

earth turned up behind them. Uncle David was driving: As he saw the boys he spoke to the horses, checked them with the reins, and stopped.

Horace and Jim walked across the plowed ground.

It was bumpy going. Sometimes they stepped on top of the layers, sometimes in the hollows 
24 JIM AND PEGGY AT MEADOWBROOK

between. Their feet sank into the soft earth, often nearly to their shoe tops. Some of the dirt got into Jim's shoes.

"Want a job, boys?" asked Uncle David.

"All right," said Horace.

"Sure," said Jim.

"I'll tell you what you do," said Uncle David. "See those boards and things in the grass? If you'll carry them over to the fence there and pile them up, I think that'll be your share. Watch out for nails."

Horace looked at the strip of sod remaining.

"Can't finish this before dinner, can you?" he asked.

"Oh, we'll clean it up by noon," said his father.

Uncle David started the horses. Jim watched the layer of earth slide smoothly from the moldboard, turning over next to the open space where one of the wheels was running. At the end of the row Uncle David put his weight on a lever fastencd beside his seat. The plow that had been doing the work rose in the air and stayed there. The horses turned and faced back for another trip. Uncle David let another lever come up. The plow on the other side, that had been riding above the ground, sank into the earth. A new furrow began. It was fun to watch.

As Uncle David drew near them, Horace called to him. 
"Let me try it, once," he said.

Uncle David stepped down from the iron seat. Horace climbed up, and drove the horses to the end of a furrow and back.

Then Jim and Horace hunted up the boards and sticks, and began carrying them to the fence.

They had finished their work, and were sitting on the fence watching the plow again when Uncle David stopped near them on one of his rounds.

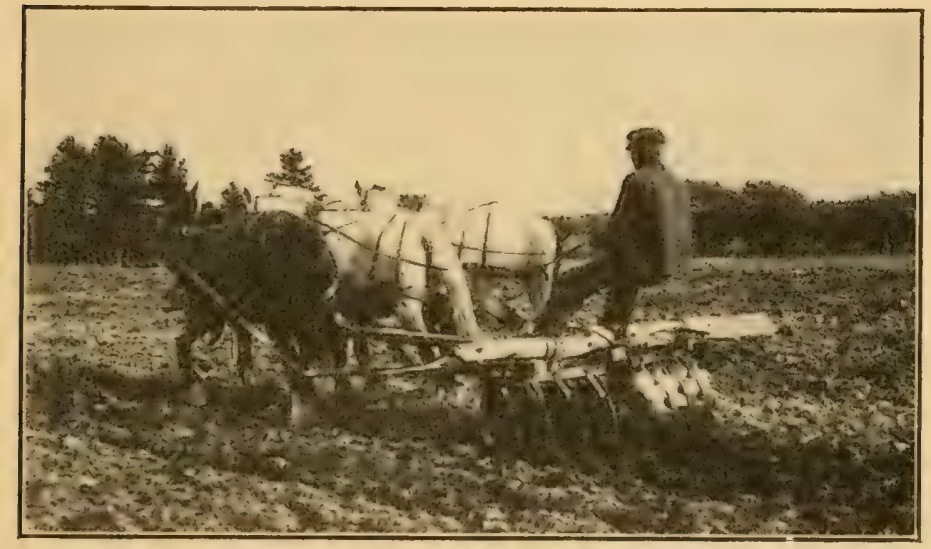

Three Horses Pulled the Cutaway Harrow

"Boys," he said, "Mr. Reynolds has bought a big, new cutaway harrow. You two might go over and watch it work. You'll have time before dinner."

So they went over a fence, through another field, down through a meadow, up through a woods, and came out at the Reynolds farm. 
Two big gray horses and a black one were pulling the cutaway. It had eight queer-shaped disks under it, fastened in a row. Each was made of steel, curved like a kind of lid, with deep notches cut into the edge. As the harrow moved along the disks kept turning in the earth; and, as they turned, the soil was tossed and ground until it was all loose and crumbly. Mr. Reynolds rode on an iron seat fastened to the middle of the harrow. Sometimes his seat jerked around here and there.

When they had watched the horses make four or five rounds of the field, Jim and Horace started down the road for home. On the way they passed Andy Wiggin's. Andy worked for Uncle David. He and Aunt Hannah Wiggin lived in a house near the road, on a part of Uncle David's farm.

Andy was turning up a new garden space for next year. His white horse was hitched to a walking-plow. This plow went through the ground much like Uncle David's, but it wasn't mounted on wheels and it wasn't as big. At the back of it were wood handles. Andy walked along, holding to these and guiding the plow while he drove. The earth was turned up just as when Uncle David was driving the riding-plow, but the work was harder and slower. Sometimes Andy had to use all his strength to keep the plow pointed right in the ground. Once it hit a root or a stone and 
switched up out of the earth. Holding it and guiding it made Andy walk with funny, uneven

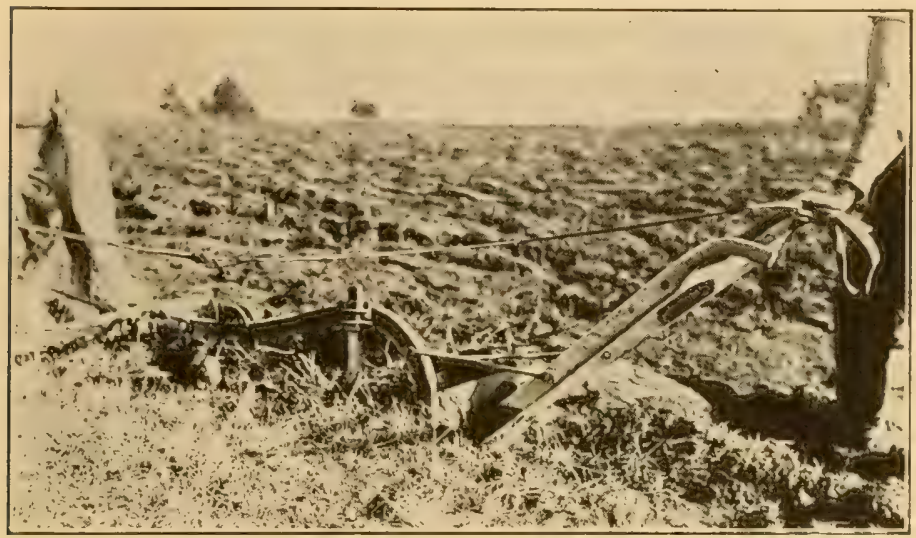

Andy Walked along Guiding the Plow

steps, this way and that. Jim did not like this plow as well as Uncle David's machine.

They turned up the lane and saw Peggy and Jane on the porch, looking for them, to tell them that dinner was waiting. 


\section{CHAPTER V}

\section{THE PIGS AND SUSAN}

HorAcE and Jim finished dinner with a third glass of milk each; and Peggy was not far behind. Before they left the table Horace looked across at his father for a moment, and then asked, "What are we going to do this afternoon, Dad ?"

Uncle David suspected that Horace had a plan of his own. He hesitated, for it was a fine, warm day and he knew where Horace would like to go with Jim for the afternoon. He'd like to go himself. But there was real work that needed doing, and it couldn't very well wait. In fact there was more than could be done that day, or in several days.

"Well, Son," he said, "I guess we'd better get those fall apples picked and put away."

Out in the yard a calf mooed and a duck quacked. "Have you children said. 'How d'do' to all the stock and pets?" asked Uncle David.

Jim shook his head

"I've seen Peter, and Jerry and Brownie," said Peggy.

"The girls were busy helping me all morning," 
explained Aunt Lucy, "and perhaps Jim and Horace were busy, too."

"Well, I'll tell you," proposed Uncle David, "it will take Andy and me half an hour or so to fix up the apple barrels. You youngsters can make the rounds while we're getting them ready."

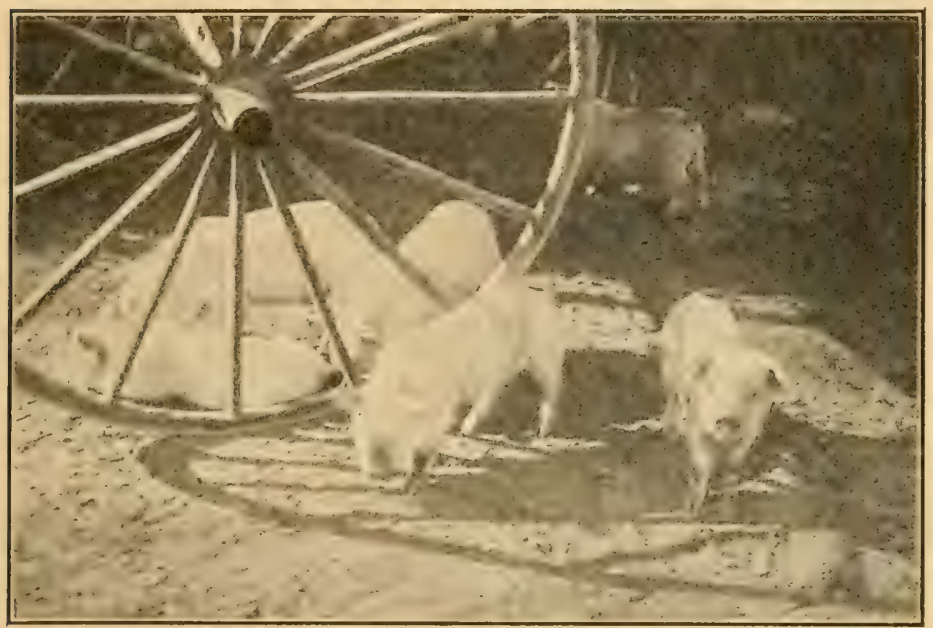

Half a Dozen Little White Pigs Were in the Tool Shed

That suited all of them, and they trooped out into the yard.

Half a dozen little white pigs were dozing around the wheels of an old buggy stored away in one of the openings of the tool shed. They waked up and scampered away as they saw the children coming. Then they came running back again. "Wait a minute," said Horace. 
He ran down to the garden, pulled up four or five carrots, and went into the barn for a pan of ground feed.

Two of the carrots he broke up for the pigs. They gobbled them up, chewing until their lips smacked.

In a shed, beyond, was Nellie, the mother of the little pigs. She was standing up, hanging one front legover the boards

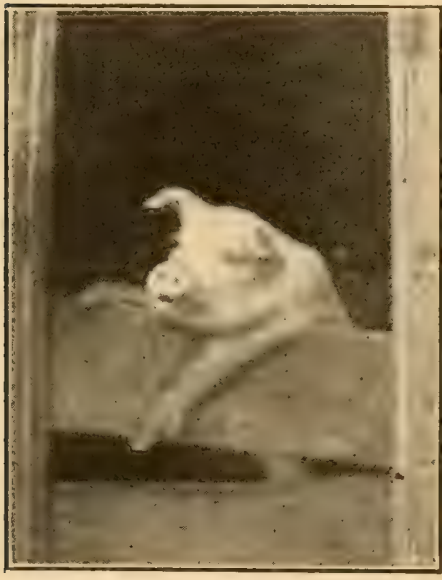

Nellie Was Standing at the DOOR nailed across the door. They threw a carrot to her. She clambered down inside to get it, and at once stood up again, waiting for more, hooking her elbow over the top board to help hold her up. It didn't take her more than ten seconds to eat a carrot, though she chewed it well, too.

"I think she'd eat a bushel of carrots in ten minutes," commented Jane.

"Well, she won't get them," replied Horace.

Beyond the tool shed they found Spot and his brother Tag. Tag lived at the Reynolds farm but spent much of his time at the North place, visiting. 


\section{THE PIGS AND SUSAN}

Spot came to meet them as soon as he saw them coming. He had seen Jim that morning, and when Jim said "Hello, Spot" he walked over and stood quietly wagging his tail while Jim patted him on the back. As they went on, both dogs followed along with them.

"Let's go see Susan," said Jane.

Out beyond the chicken house, near some apple trees, they could see a brown and white calf. She was tied with a short rope to the end of a

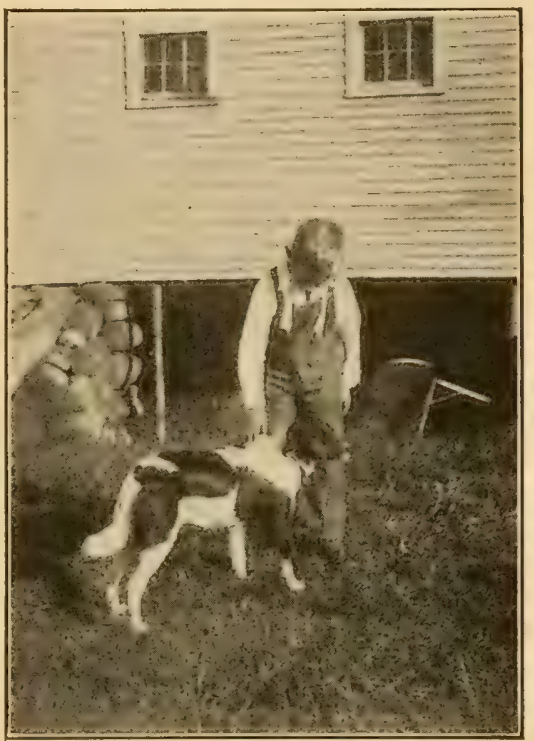

Spot Stood Wagging His Tail pole. The pole was hinged near one end to the top of a stake, and on the other end was fastened a piece of iron. If you pulled on the rope, the pole would tip down, and if you loosened the rope, up it would go again.

Susan tried to run away as they came near. She made about three jumps, and then the rope stopped her with a jerk. After that she hopped 
back and forth, stiff-legged, as far away as the rope would let her go, rolling her eyes and crying "Baa," as if the children were giants that were going to eat her up.

Horace gave Jim the pan of chopped grain. Jim held it out toward her. But Susan was sus-

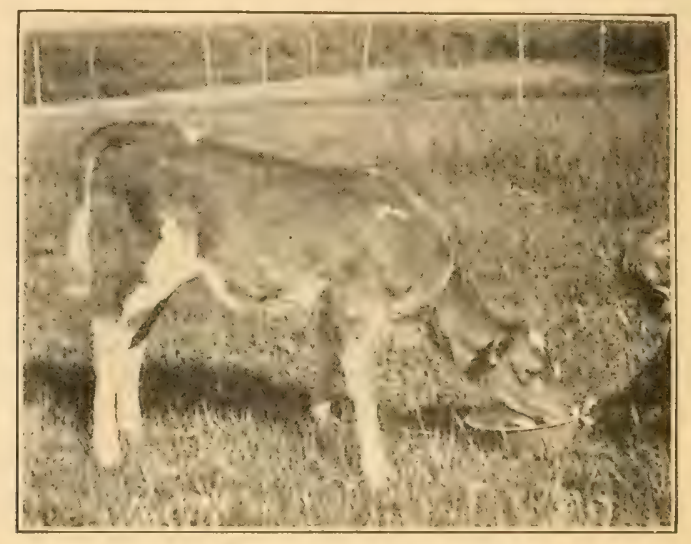

Jim Held the Pan for Susan

picious and wouldn't come. Then Jim set the pan on the ground and they all stood back while Susan came slowly up and took a taste of the grain. Pretty soon Jim stooped and gradually slipped up until he could reach out and touch the pan. For a moment Susan was going to be scared again. But the grain tasted good, and soon she forgot about the children and licked the pan clean while Jim held it for her. 
As they came back by the shed where they had been feeding carrots to Nellie, they found her still looking over the top board.

"Let's put her little piggies back with her," suggested Jane.

So they started the pigs toward the shed, while Horace held up the bottom board for them to go

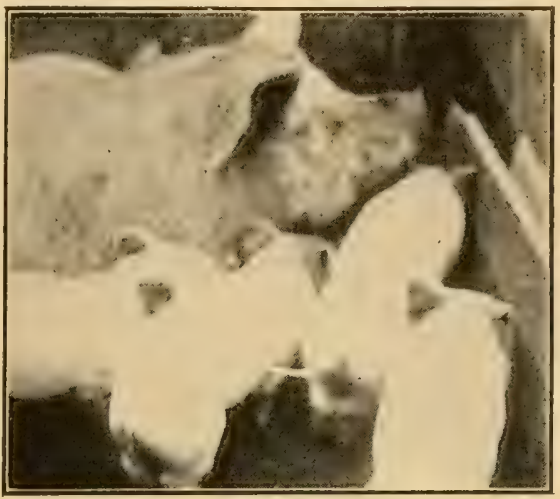

The Little Pigs Crowded around Her through. In they scampered, as fast as they could run. The children went around to the side and looked through a crack. Nellie had got down from the board where she had been standing, and all the little pigs were crowding tight around her, grunting and squealing. 


\section{CHAPTER VI}

\section{APPLES}

"CAN'Twe go down and see Eli ?" suggested Jane. "Who's Eli ?" asked Peggy.

"He's Horace's steer. Horace rides him and drives him almost anywhere."

"I drive him only with Aaron," objected Horace. "Well, Aaron's his own brother, and just like him."

"How about the apple picking?" said Horace.

For answer Jane ran over to the barn. She found her father and Andrew ready to begin. So Eli and Aaron would have to wait for another time.

Uncle David asked the girls if they would gather the fruit beneath the Grimes tree near the house. He gave them a round, deep basket, and rolled out an empty barrel, which he put where it would be handy.

Meanwhile Andy was hitching Milly to a light wagon. They piled this up with empty barrels. Horace and Jim got up on the seat with Andy, Uncle David hopped on behind, and they rattled 
away past the chicken house, to the far end of the big orchard.

There were already two ladders in neighboring trees, where they'd been used the week before in picking earlier fruit. Andy took one and Uncle David the other. It was the boys' job to gather

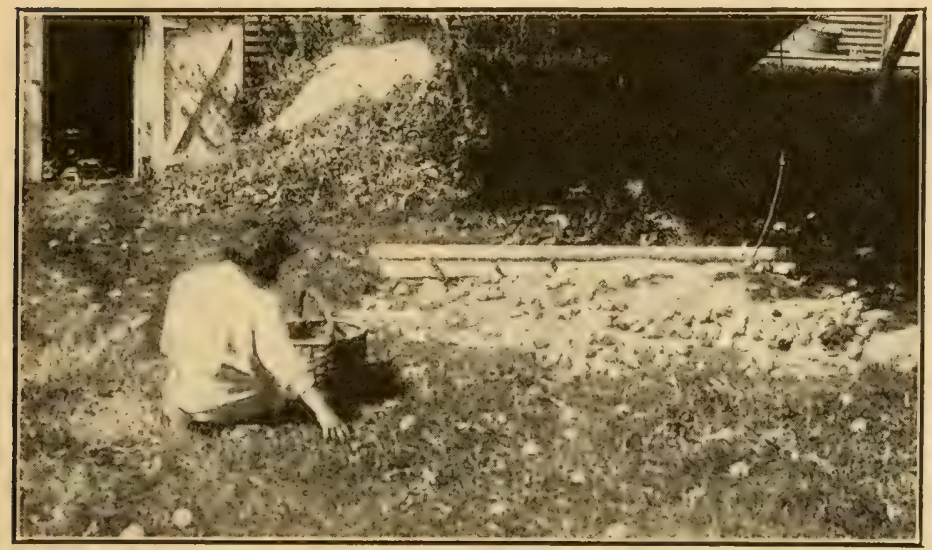

Peggy Gathered the Apples beneath the Grimes Tree

the fallen fruit, and to take the baskets from the men and empty them into the barrels.

"When you pour apples into the barrel," said Uncle David, "be careful to hold the basket down near the bottom inside, and turn it over slowly, so as not to bruise the fruit."

He explained, also, how they would need to keep the fruit gathered from the ground separate from that picked from the trees. Besides this there 


\section{JIM AND PEGGY AT MEADOWBROOK}

were different kinds of apples from different trees to keep separate.

While they were at the Grimes tree, Horace hunted up a big, sound apple and began to eat it. Jim did the same. It was crisp and juicy, and had a fine, spicy flavor. The next kind was a deep,

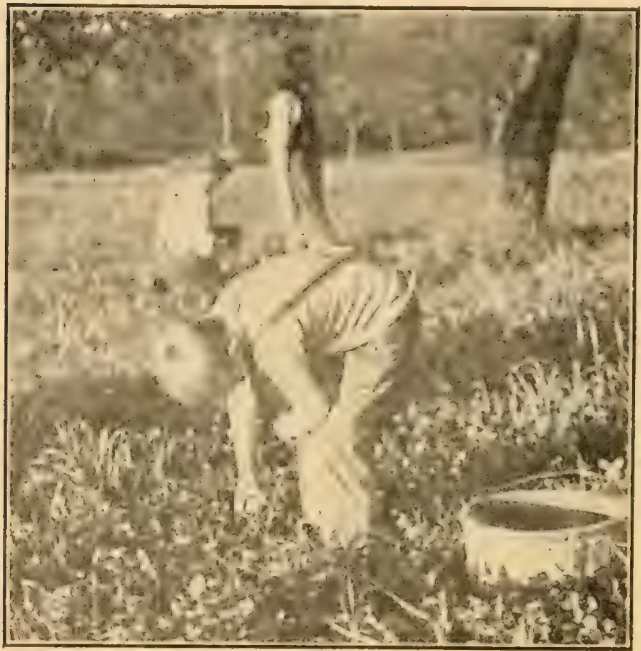

The Boys Gathered the Falien Fruit red one, at the tree where they first began picking. There were branches on the treeloaded so full that you could almost fill a basket from on e branch. Horace didn't pick an apple from the tree but got one from the ground. Uncle David did the same, and found one for Jim.

"These on the ground are mellow," he explained. "The ones on the tree are all right for picking and storing, but they're not so good yet to eat."

Next they sampled an apple with red and yellow stripes. After that Jim felt that he had eaten 
enough, though Horace managed to put away another one.

The boys worked steadily, gathering fruit, placing empty barrels, and filling them. Andy drove back to the barn for more barrels. Jim found that even an empty apple barrel feels heavier after you have carried it a few steps, and often the ground was so uneven that you didn't gain much by rolling it. A basket of apples, too, wasn't very light to lift and carry. Sometimes his back ached from stooping over, gathering fruit from the ground. But the kink would dis-

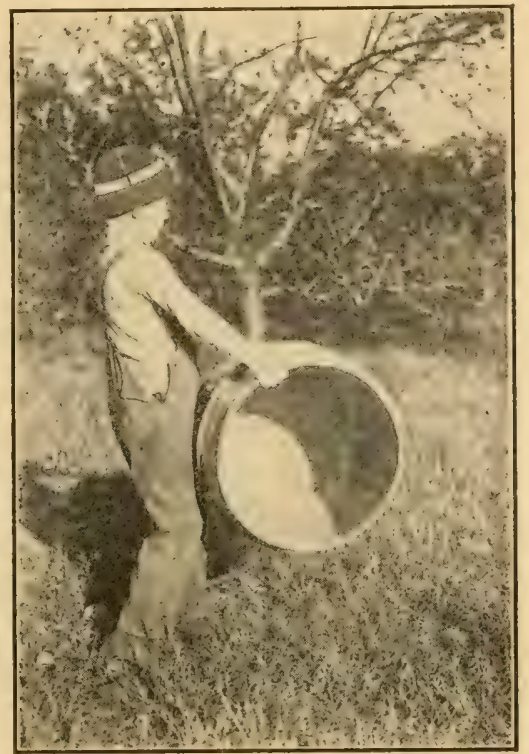

Jim Helped to Carry Empty Barrels appear when he walked around a little. And all the time the barrels kept filling up. It was pleasant to look at them, standing about.

Here and there in the orchard were young trees planted where old ones had been cut out. Around the trunk of each of these, next to the ground, a 


\section{JIM AND PEGGY AT MEADOWBROOK}

piece of wire netting was fastened. He asked Horace about it, and learned that this was to keep rabbits and mice from gnawing the bark of the young trees and killing them.

"Rabbits are bad almost any time," explained Horace. "The mice are worse in winter. Some-

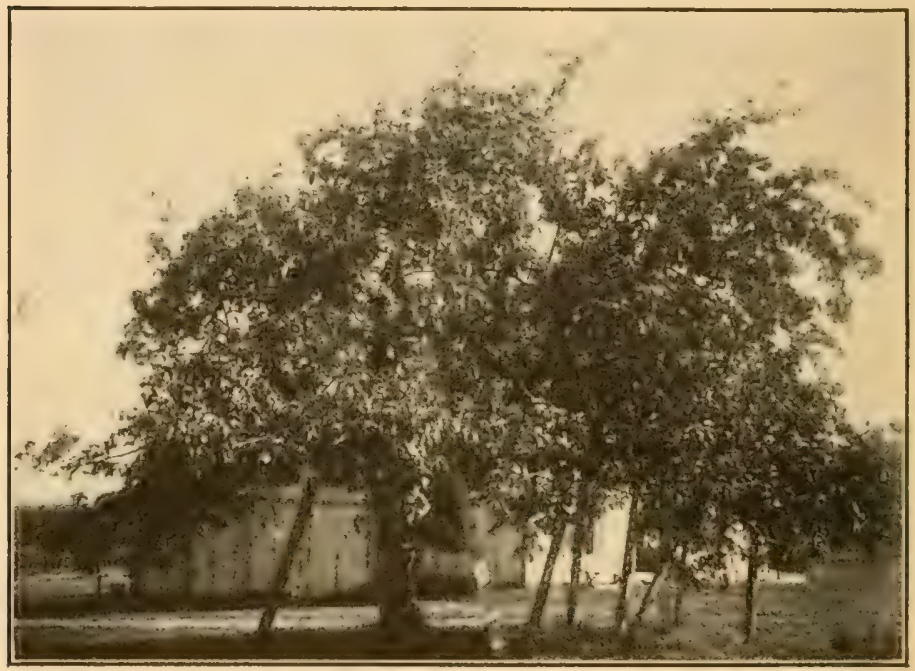

The Last Tree was Propped up with Boards and Poles

times when there's snow they make tunnels under it to the trees."

"Do rabbits come here into this orchard?" asked Jim.

"Sure," said Horace. "Nearly every day."

"Do you ever shoot them?"

"Lots of times. That is, dad does. We shoot 
them in fall and winter. - Maybe he'll take us hunting while you're here."

They worked on until the sun began to sink in the west. The last tree that they came to, a big one standing near a shed, was so loaded with apples that it had been propped up with boards and poles to keep the branches from breaking. Uncle David looked it over, but decided they'd leave it until the next day.

He sent the boys up to the house, then, to get ready for supper. He and Andrew began

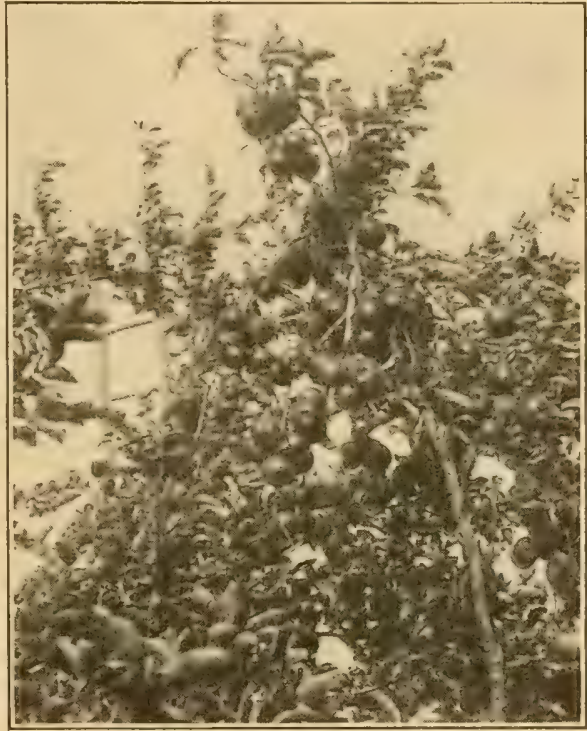

A Branch with Its Load of Apples loading the full barrels into the wagon, to haul them to the shelter of the tool shed for the night.

When Aunt Lucy saw the boys coming toward the kitchen, she filled a basin with warm water, carried it outside and set it on the ground near the bench by the door.

"Slip off your shoes and stockings, Jim," she 
said. "The hot water'll be good for your feet." She smiled and added, "Maybe a little soap won't hurt, cither." A moment afterward she came

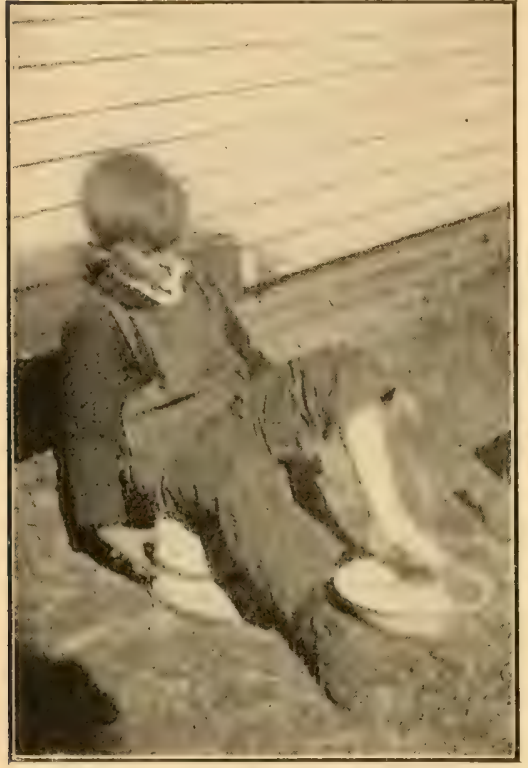

Jim Found the Water Pretty Hot out with clean stockings for both boys. "Never mind the shoes," she told them.

Jim thought the water pretty hot at first. But after he'd once . put his foot into it and kept it there for a moment, the water seemed pretty good.

It was after dark when Uncle David finished the task of bringing in the apples. Jim was too tired to think much at supper. But he had seen many things, and there were a dozen questions that he wanted to ask to-morrow. Peggy, too, was tired, and silent.

Half an hour after supper both children were in bed and asleep. 


\section{CHAPTER VII \\ ELI AND AARON}

Jim thought that he was the first one awake next morning. When he opened his eyes it was daylight. Horace was still asleep. There was no sound anywhere in the house, though outdoors the chickens were astir. The same white rooster was crowing. There were little noises coming from the direction of the barnyard.

In the room where the girls were sleeping Peggy was awake, too. She had opened her eyes about the time Jim did. Before long both children heard footsteps coming down the hall. Aunt Lucy opened Jim's door to call Horace. Then she opened Peggy's door to call Jane.

As soon as the boys had dressed they hurried downstairs. In the summer kitchen they met Uncle David coming in with a pail of milk in each hand. He and Andrew had finished the milking.

The girls came down a moment later.

"Now's our chance for Eli and Aaron," said Jane.

So they trailed out, crossed the farmyard, and 
42 JIM AND PEGGY AT MEADOWBROOK

opened the gate to the lane. Billy and Queen, the two colts, were in the feed yard and heard them coming. When the children arrived at the bars the colts were waiting, with their heads close together, over the top bar.

Horace fished out some loaf sugar from a pocket where he'd stowed it the day before. He showed

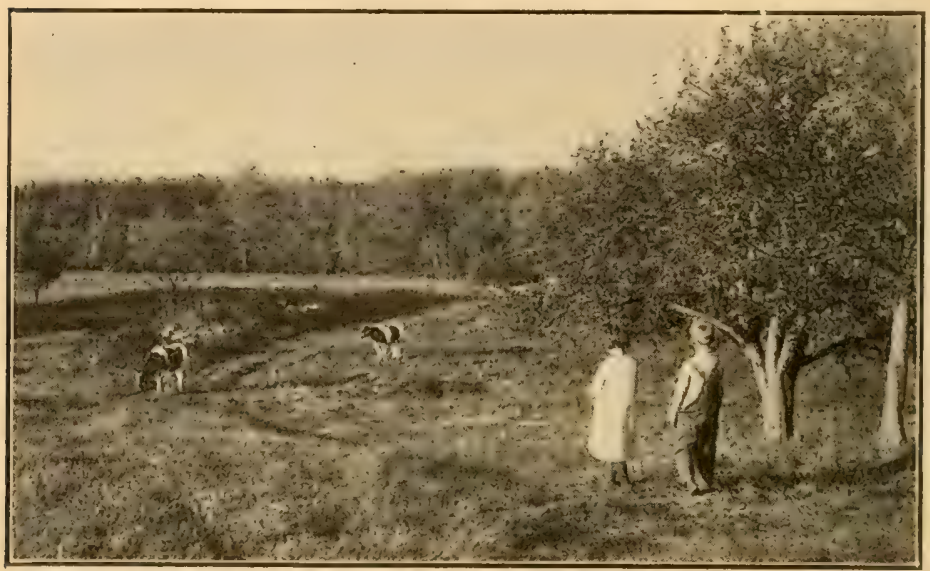

The Children Walked outt to the Pasture

Peggy how to hold a lump in the palm of her open hand. Holding it that way she could feed it to the colts without the chance that her hand would be nipped. The colts would pick it up with their lips, instead of taking it with their teeth.

The children walked on out to the pasture where Eli and Aaron were fastened with ropes tied to stakes. The steers looked pretty big to Jim and 


\section{ELI AND AARON}

Peggy. They were much larger than Susan, the calf. Their heads were bigger, their necks were heavy, and their legs were thick and stocky.

Horace picked an apple from a tree near by, and Jim held it out to Eli. At first Eli would only sniff at it. He backed away and lowered his head when Jim took a step forward. In fact Jim was a

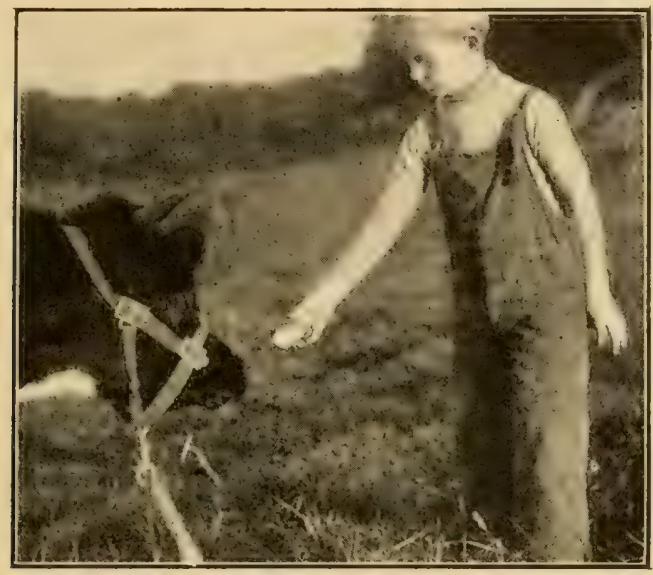

Jim Offered the Apple to Eli

little afraid of him and he was a little afraid of Jim. After a time he grew more friendly. Finally he stood still while Jim stepped up close to his head and gave him the apple.

"Get up on his back," suggested Horace. "I'll hold his head. He'll stand still all right, maybe."

Jim didn't know what to think of that. But 


\section{$4+$ JIM AND PEGGY AT MEADOWBROOK}

Horace urged him to try it. So he slipped around to Eli's side and started to climb up. At once Eli scrambled away. Horace held tight to his head and Jim tried again, on the other side. Eli backed around in the other direction. Horace

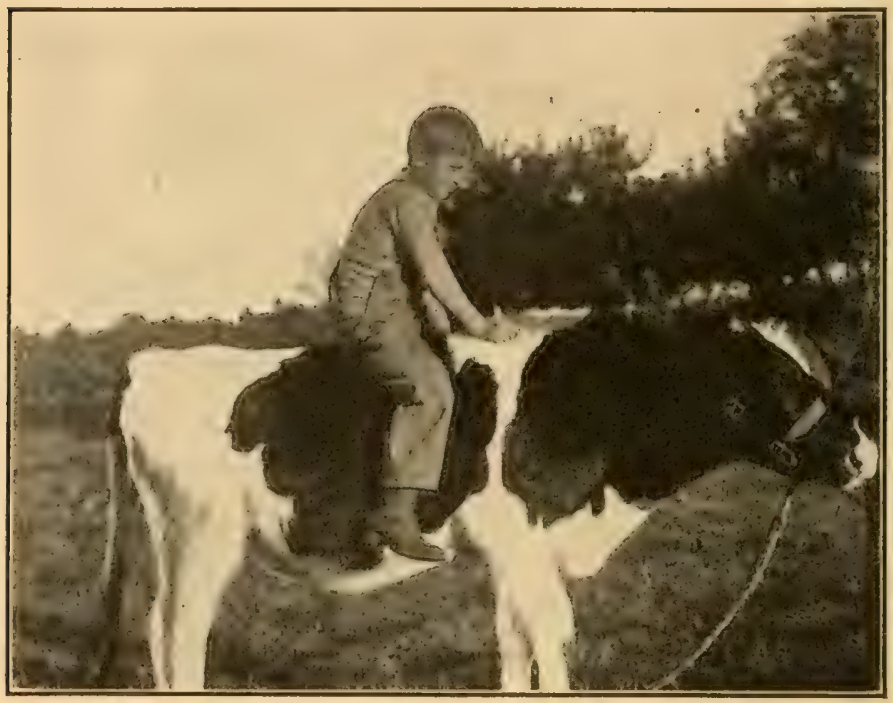

Jim Climbed up on Eli's Back

picked another apple, and while he was feeding it to Eli, Jim slipped up on his back. But Jim didn't stay long. In a moment Eli put down his head and began to back around, pulling Horace with him. The girls laughed and squealed. Jim dug his fingers into the hair on Eli's shoulder and gripped Eli's sides with his knees and feet. Eli 
arched his back up, shook his head, jumped sidewise - and Jim slid off to the ground.

They went back to the house, then, to see if breakfast was ready. Brownie and Jerry were on hand as usual, near the kitchen door, and eyed them as they came up. The two ducks were not

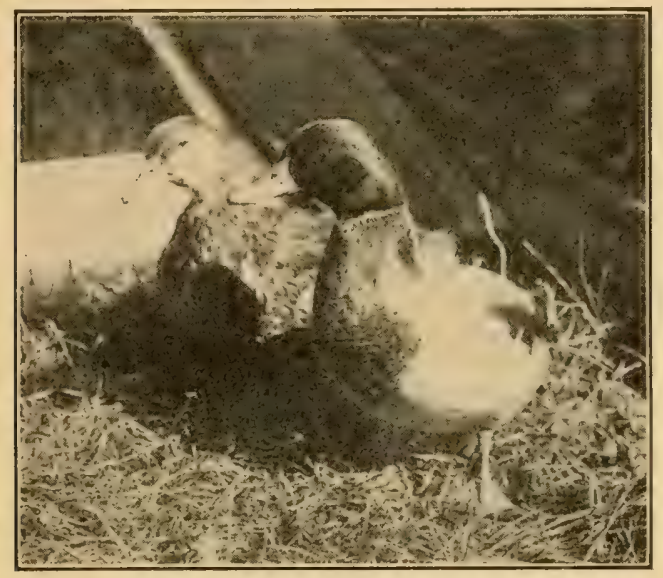

Brownie and Jerry Were on Hand

like the others on the farm. They were really mallards, a kind of wild duck. A neighbor had found them in a marsh, when they were tiny ducklings, and had given them to Jane and Horace to raise. So they grew up with the farm as their home, and stayed close by the house. Jane and Horace could handle them and pet them, but toward anyone else they were always a little timid and suspicious. If you came too near they would 


\section{JIM AND PEGGY AT MEADOWBROOK}

sidle away, watching you with beady eyes and making queer noises, like "Quirk, quirk." Usually Brownie was the braver of the two. Jerry always let her lead, while he followed a little behind.

Horace went into the house for a basin of water, and he and Jim washed up for breakfast.

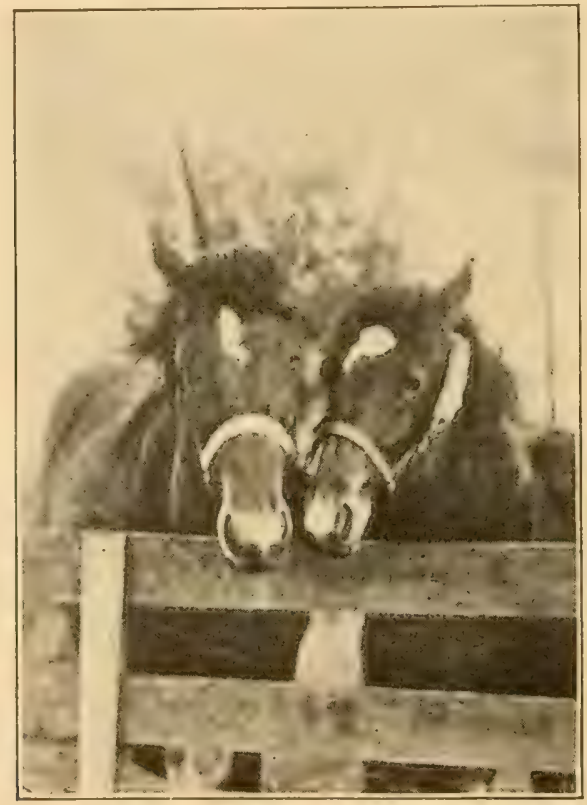

Billy and Queen at the Feed Yard Gate 


\section{CHAPTER VIII}

\section{CHORES}

WHEN the children came out from breakfast they heard some one pounding in the barn. A moment later they caught sight of Andy carrying an empty barrel to the wagon. There were still more apples to be picked, while the weather was good.

Aunt Lucy came to the door.

"Horace," she said, "your father would like to have you feed the stock this morning. After that I think he needs you in the orchard."

She smiled at Jane and Peggy, "I won-

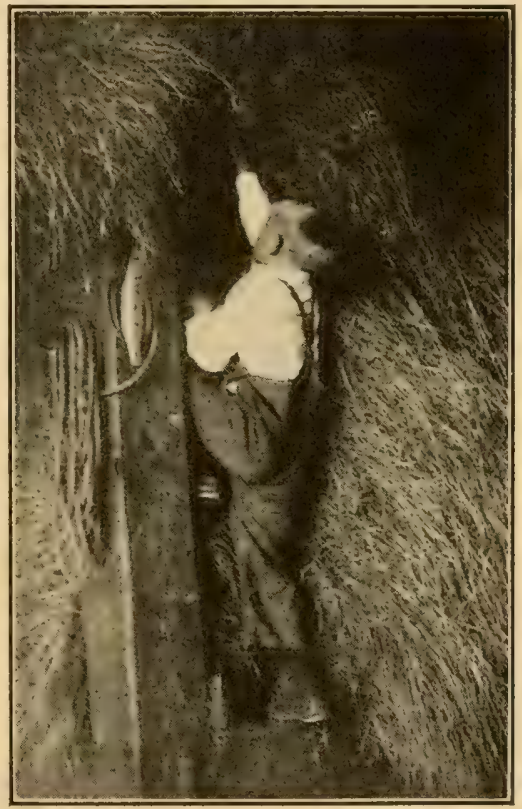

A Ladder Was Fastened against THE HAY der if you girls won't help me in the kitchen for a while." 
48 JIM AND PEGGY AT MEADOWBROOK

The boys crossed the yard and went into the barn by the big, open double door. On the right there was a solid wall of hay, extending back nearly to the other end of the barn. A few feet from the door a ladder was fastened against the hay, running straight up from the floor toward the roof, high

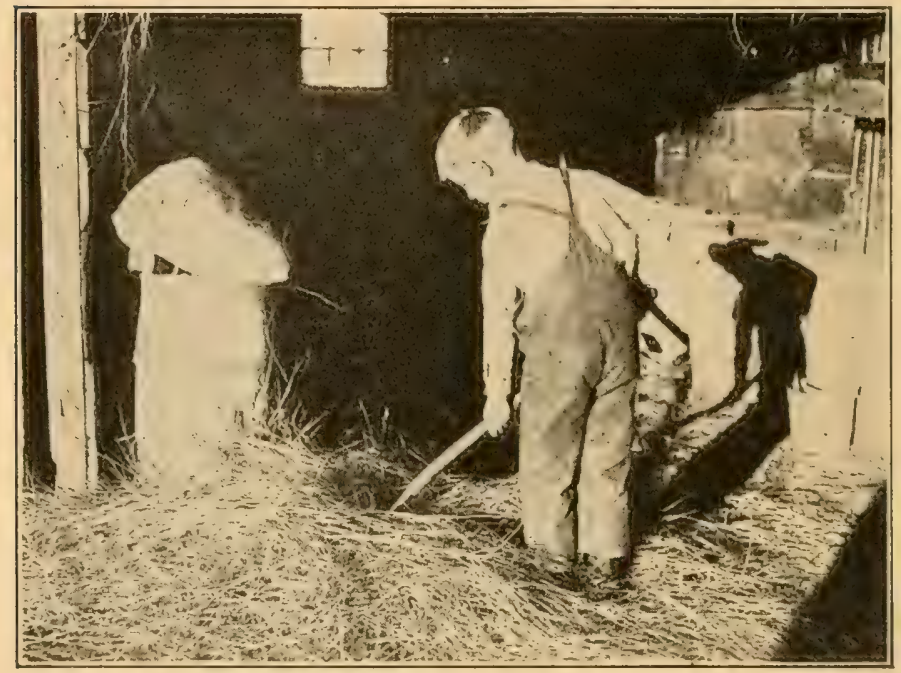

They Carried the Hay to the Horses

overhead. Horace scrambled up the ladder, and Jim climbed up after him.

The hay wasn't level on top, but was in heaps, like little hills. It was slippery, too. You had to crawl on your hands and knees, and dig your toes in, when you first swung off the ladder.

A pitchfork, with a straight, wooden handle and 
three long, slender tines, was standing near. Horace stuck it into one of the heaps of hay, lifted and pushed, and shoved the whole heap off to the floor below. He sent another heap flying down. Soon there was a big pile of hay on the floor. Then both boys scrambled over to the ladder and climbed down.

On the left of the wide middle space in the barn, toward the far end, there was a board partition. There were openings in this, about three feet up from the floor. They were like windows without any glass, but were wider and not so high. At the bottom of each opening a kind of door was hinged, that let down against the partition.

When Jim looked through one of the openings, he saw a horse's head, just inside. It was big Dan. Next was Ben, and next beyond was Milly.

Standing in a corner were two more pitchforks. Horace took one, and Jim the other. Then both boys carried big forkfuls of hay to the horses, shoving the hay through the openings. As soon as the first of it came within reach of a horse, he stuck out his head and took a big mouthful.

Across from the horses was a row of barrels. Jim looked into these and found that there was grain in them; corn in one, oats in another, a kind of mixed or cracked grain in a third, and a ground feed, like coarse flour, in the last one. 


\section{JIM AND PEGGY AT MEADOWBROOK}

Horace was looking for a round, wooden measure that was used for dipping up the grain. Jim found it in the bottom of a barrel that was nearly empty. They filled it with corn, and divided the grain between Dan and Ben, pouring it into a

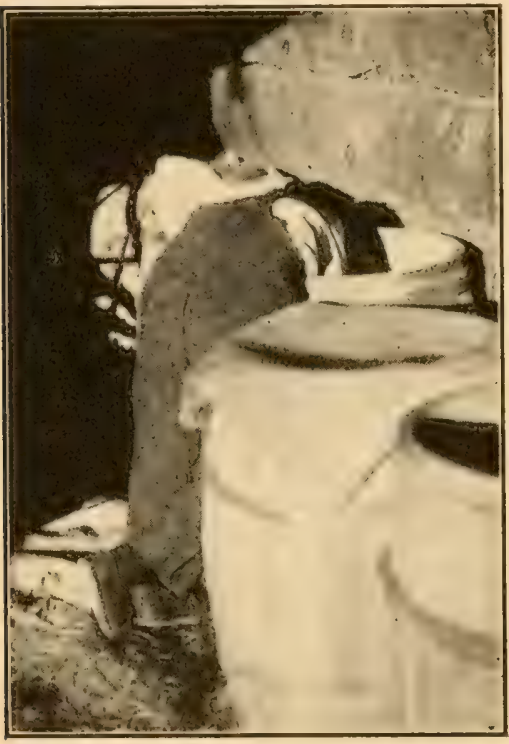

Jim Folnd the Measlere in one of the Barrels shallow box that stood in the space near each horse's head. Then they filled the measure with oats, and divided that between the two horses. After that Milly received her share, though not so much as Dan or Ben.

Andy had taken the cows to their pasture before Horace and Jim came out from breakfast. The boys looked into the part of the barn where the cows were kept. It didn't have separate stalls boarded all the way up, like those for the horses, but was open all along. Where each cow's head would be there was a queer wooden framework that would open a little or close a little. That is 
the way the cows were fastened in their stalls. Each cow would put her head through one of the frames. Then when it was closed she couldn't get away, though she could move her head around, and up and down, all she pleased.

The pigs came next. Horace brought two iron pails from the corner. The boys placed in each pail two measures of the ground feed from the last barrel. Then they carried the pails to the house. In the summer kitchen there was a big can of skim milk that Uncle David had put there after it had come from the separator. They tipped the can up and poured milk

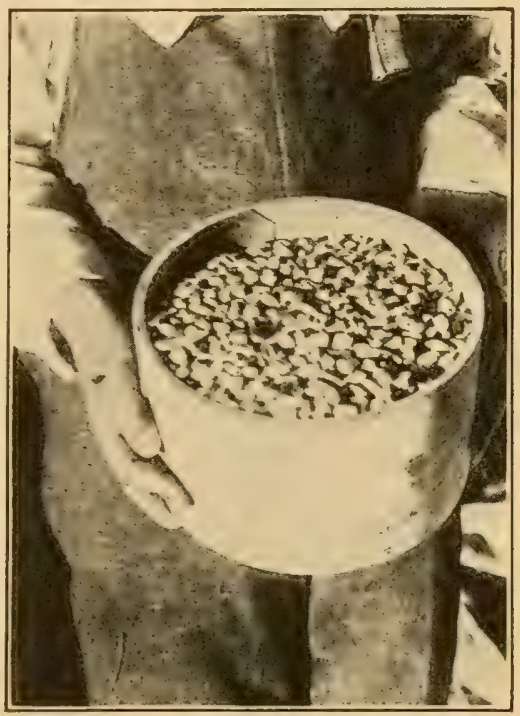

They Filled the Measure with Corn carefully into each pail until it was nearly full. Horace took one pail, Jim the other, and they crossed the yard to the shed where Nellie and her little white pigs lived. There was a trough inside the shed, close to the front. A wooden spout led from outside through a hole in the wall 


\section{JIM AND PEGGY AT MEADOWBROOK}

to the trough. The boys poured the milk and meal down this spout. Then they looked in the door. The pigs and their

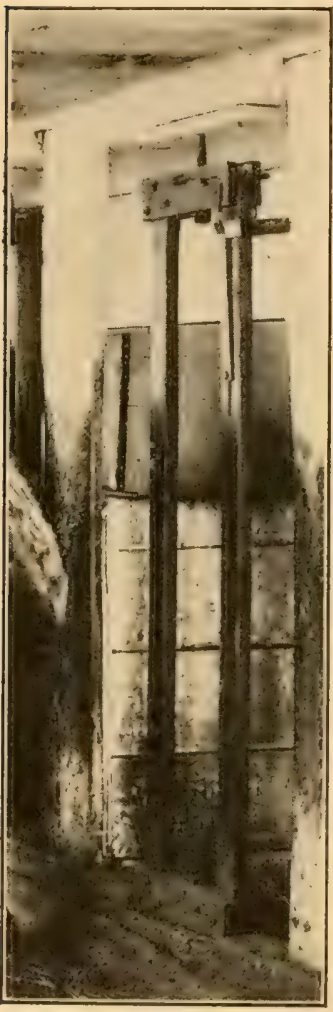

AT THE HEAD OF EAcH Stali. was a Framework mother were crowding and pushing around the trough. One little pig was standing in it.

The boys went back to the barn and the house twice more, and each time filled up the pails with the coarse meal and skim milk. These lots went to some black pigs back of the barn - fine, shiny fellows, almost as big as Nellie.

When they had finished their chores, Uncle David and Andrew were ready with the barrels. Horace thought of the work that seemed always waiting to be done, and wondered how well Jim liked their life on the farm. But Jim appeared interested in all of it, and eager to do more.

They spent the rest of the morning helping at the task of picking and barreling apples. 


\section{CHAPTER IX}

\section{PEGGY'S PIES}

While Jim and Horace were busy in the orchard with Uncle David, Peggy and Jane spent the morning with Aunt Lucy.

As soon as breakfast was over the girls went upstairs and spread back the covers on the beds, opening all of the windows. They left the beds that way, to air.

When they returned to the kitchen, Aunt Lucy had cleared off the breakfast table, and filled a dishpan with steaming, hot water. Jane rolled up her sleeves and put on an apron that covered her all round and buttoned down the back. Peggy procured a supply of dish-towels. In half an hour the girls had finished the dishes. Aunt Lucy put them away in the cupboard, as Peggy wiped them dry.

There were a few towels and napkins that Aunt Lucy was going to wash, for they would be needed before next week. Jane liked to help with things of this kind, and asked to do them. She turned a kitchen chair on its side and put a tub on it. Soon 


\section{JIM AND PEGGY AT MEADOWBROOK}

she was busy rubbing the linen up and down the washboard.

Aunt Lucy had a plan to propose.

"Peggy," she said, "how would you like to make some pumpkin pies for dinner?"

Peggy looked wistful.

"I'd like to, Aunt Lucy, but I don't know how."

"I'll show you," Aunt Lucy assured her.

Peggy was still doubtful, though she was eager to

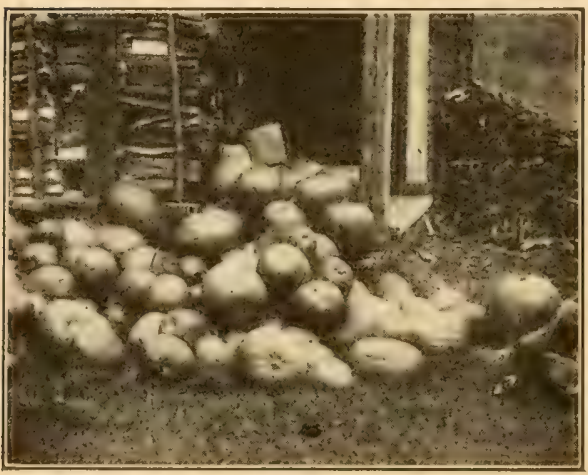

There was a Heap of Pumpkins try. "Suppose I'd spoil them?" she said.

"Well, we aren't going to have that kind of pies," declared Aunt Lucy.

There was a heap of pumpkins outside, near the woodshed, where Andrew had piled them. Peggy went out, found a round, smooth, brown one, and brought it in. She and Aunt Lucy cut it in halves, scraped the seeds out, cut each half into small pieces, and peeled each piece. Then they put the pieces into a steamer, and set them on the stove to cook.

While the pumpkin was cooking, Peggy and Aunt 
Lucy swept and dusted the living-room, gathered up the books and papers that were about, and put the place in order. After that they made the beds. When they came back to the kitchen the pumpkin was done. They took it off the stove, and turned it out into a colander to cool and drain.

Next they prepared the pie crust. Aunt Lucy showed Peggy how to sift the flour and work the lard into it.

"You must always have your lard quite cold," she said, "and you mustn't work

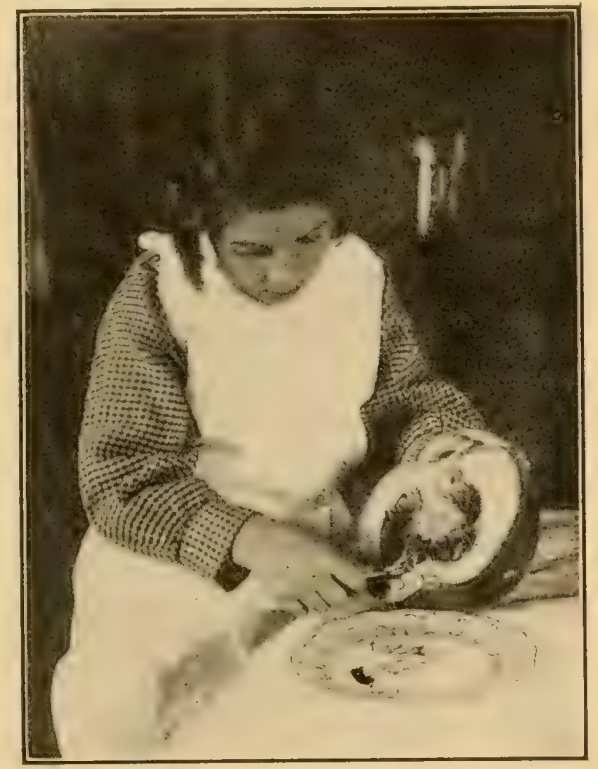

Peggy Scraped the Seeds out

it with your hands very much. It's better to chop it in with a knife."

Peggy rolled out the crust. Sometimes it wanted to stick to the rolling pin, but a little flour made it behave. Aunt Lucy lined the piepans with it, crimping the edges all round with her thumb and finger. 
56 JIM AND PEGGY AT MEADOWBROOK

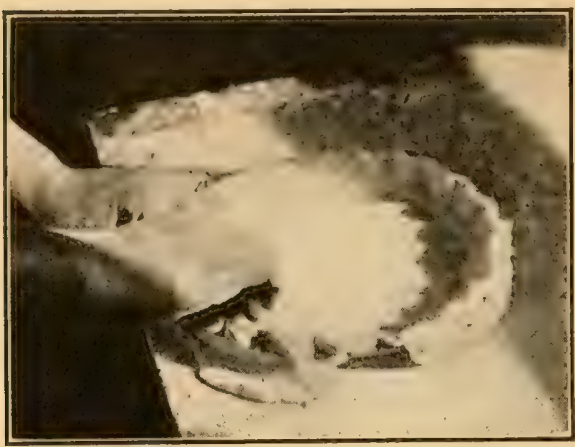

Aunt Lucy Lined the Pie Pans
When the pumpkin was cool they worked it through the colander to get it all smooth. Then Aunt Lucy showed Peggy how to prepare a custard, with milk and eggs and sugar. They mixed the pumpkin pulp with this, and added brown spices from little tin cans in the cupboard. Then they filled the pie pans as full as they would hold.

The oven was hot - "Just about right," Aunt Lucy. declared. If it was too hot, she said, the custard would boil and wouldn't be nice; and if it wasn't hot enough the crust wouldn't bake right. So in the pies went.

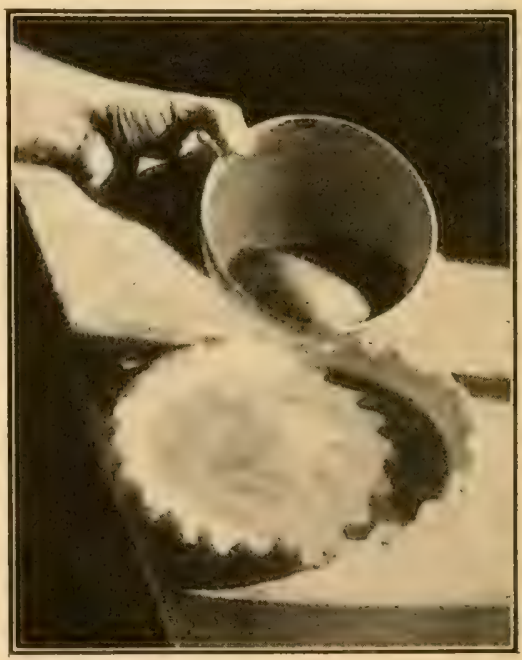

They Filled the Pie Pans as Full AS THEY WOUld HOLd 
"How long will it take them?" asked Peggy. "Just about half an hour," said Aunt Lucy. Peggy sat down and watched the clock. It seemed a long time, and she felt pretty sure that the pies would be burned. Once Aunt Lucy looked in, but the oven door was open for only an instant, and all that Peggy saw was just a glimpse.

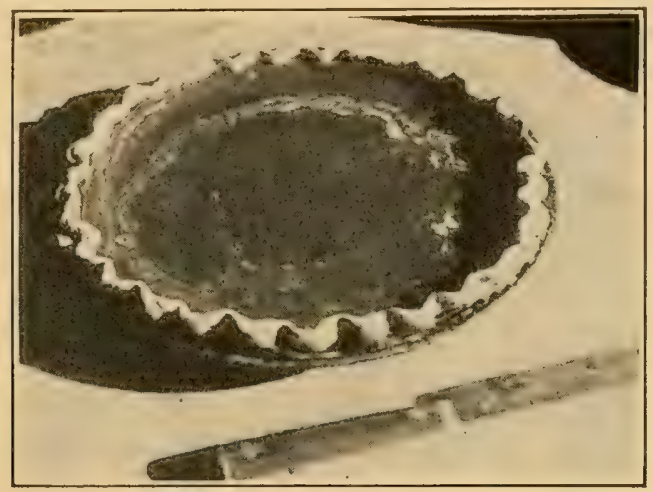

Each Pie was a Beautiful Dark Brown

Finally the time was up. Aunt Lucy took a holder, opened the oven door, and lifted the pies out one by one. They were a beautiful dark brown, and the crust looked just right. Peggy carried them carefully to a shelf in the summer kitchen, where they would cool.

When Uncle David asked for a third piece at dinner, and Aunt Lucy told him who had helped make the pies, Peggy was quite proud. 


\section{CHAPTER X}

\section{CORN}

UnCLE David came out with the boys after dinner, and sat with them on the porch for a few minutes. Jim wanted to ask about some of the things that he'd seen, but he couldn't tell where to begin. There were so many things that were new and interesting.

Before he could get started, Andrew came in from the road, and Uncle David stood up.

"Mighty good weather, Andy," he remarked. "What do you say to cutting that piece of corn, over beyond the brook ?"

Andrew looked at the sky and studied the clouds for a moment.

"Well," he replied, "don't know but we'd better. Looks like rain to-night or to-morrow."

Jim waited to hear whether he and Horace were to go with the men; but Uncle David and Andrew started to walk away.

"Can we go 'long, Uncle David ?" asked Jim. "Sure, if you want to," said Uncle David.

Horace was about to suggest a different plan, so far as he and Jim were concerned. But he re- 
membered what his father had said about having Jim learn all about the farm, so he said nothing. Besides, Jim seemed anxious to go.

The four of them - Uncle David, Andrew and the boys - walked out to the barn. Andrew went into the tool room, and came out with two queerlooking knives. They had wide heavy blades

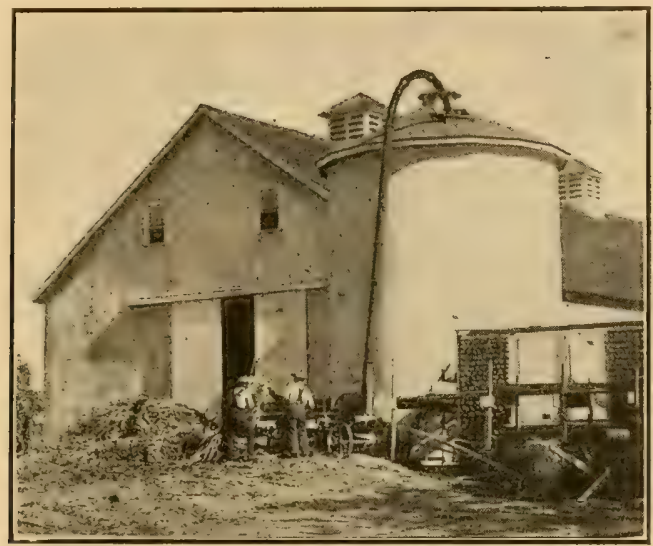

There was a Silo outside the Barn

and short wooden handles, set at almost right angles to the blades. These were the knives made for cutting corn.

As they went out through the far end of the barn Uncle David stopped by a machine that stood outside, near the door. It had a big enclosed part in the middle, made of tin or iron. From one side of this an iron pipe went straight 
up as high as the roof of the barn, and then curved over. The end of it disappeared above the top of a queer, round building that rose in the air, close to the rear wall of the barn. There were no windows in the round building, nor any door that they could see from where they stood.

"This is our new silo, Jim," said Uncle David,

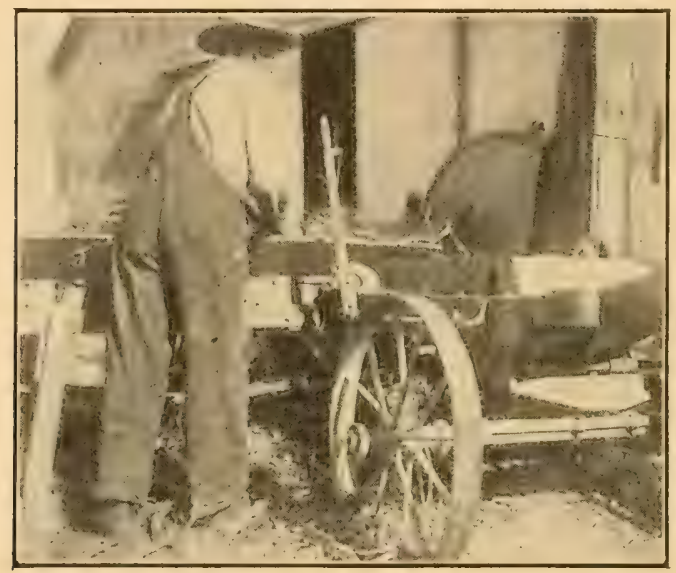

The Corn was Fed into an Ensilage Cutter

pointing to the round building. "Here's where we store our ensilage for the cows."

"What is ensilage?" asked Jim.

"It's corn," explained Uncle David, "cut green, and chopped up, stalks and all. This machine is the cutter that chops it up. We put the stalks in at this side, through that hole in the round, middle part. There's a thing in there that goes round and 
has knives on it. You can see the pulley on the other side. It's run by a gasoline engine. The pieces of corn are blown up through the tall pipe and into the top of the silo."

"How do you get it out ?" asked Jim.

Uncle David took him around to the other side and showed him a row of doors, all the way from the bottom to the top of the silo. All were closed now, except the top one.

"We had nice ensilage corn this year, didn't we, Andrew," remarked Uncle David. "Some of it was nearly three times as tall as your head. Even Jane couldn't

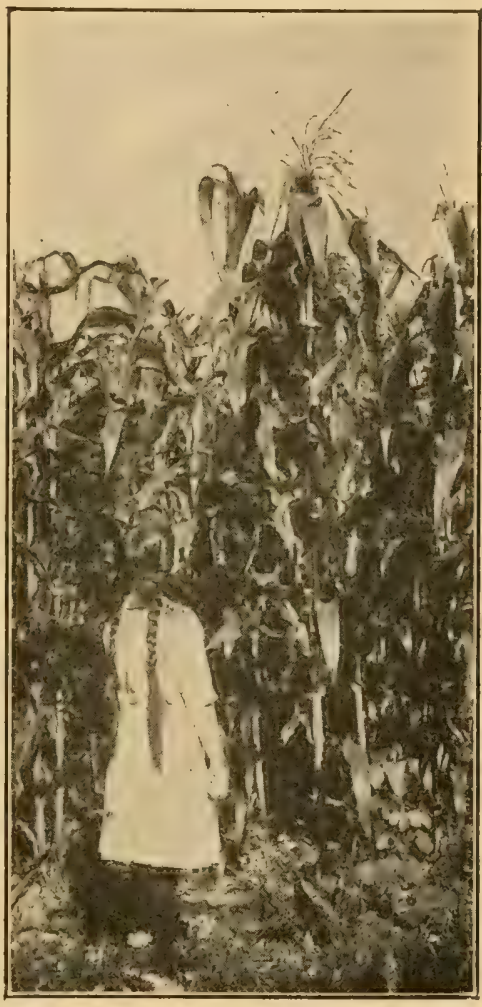

The Corn was twice as Tall as JANE begin to reach the top leaves. Mr. Reynolds cut it for us. He has a binder that cuts it and ties it up. It was all that three horses could do to pull the machine through 


\section{JIM AND PEGGY AT MEADOWBROOK}

it. You see we cut the ensilage corn while it's still green, before there's any frost. When it's packed down in the silo it keeps nice and fresh, and makes good feed for the cows."

They walked on through a meadow, crossed the brook, and came out at the cornfield that Uncle

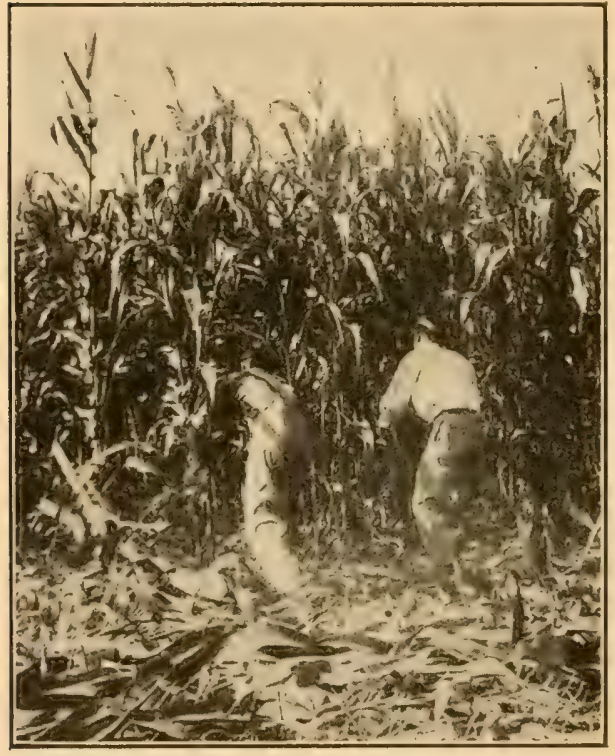

They began Cutting the Corn

David had. pointed out from the porch. The topmost leaves of the corn wer e touched with frost, so that the y w e r e brown instead of green, and rattled in the breeze.

Uncle David and Andrew started in with the corn knives, cutting off the stalks a few inches above the ground. The ears were solid and heavy, and bent over, away from the stalk. Some stalks had only one ear, many had two, and a few had three. The silk at the end of each ear was brown and dry. 


\section{CORN}

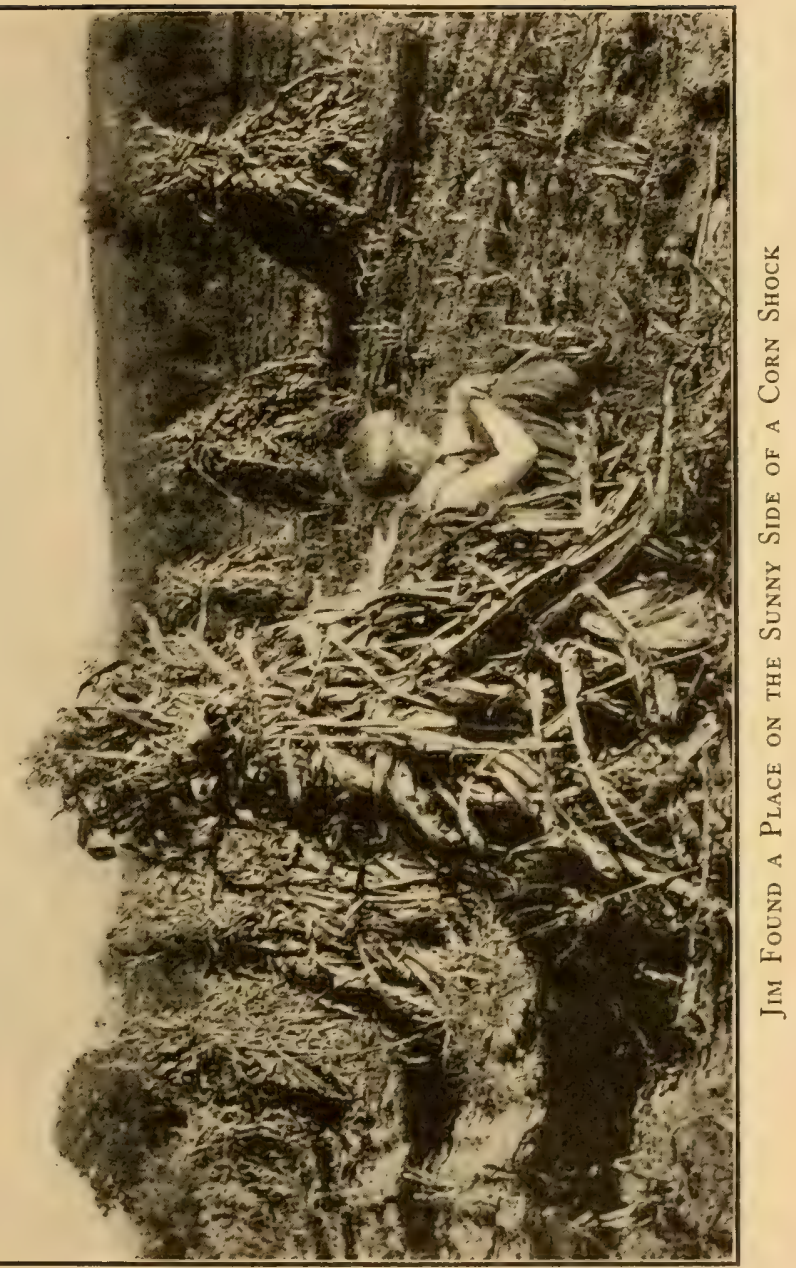




\section{JIM AND PEGGY AT MEADOWBROOK}

As the stalks were cut off, Horace and Jim, with help from Andy, gathered them up, tied them into bundles, and made them into shocks. They set them up with the butt ends on the ground and the tops leaning together, adding more and more all around until the shock was so big that you couldn't see the other side without walking around. Then Andy came and bound the top of the shock to keep it from being blown down or falling apart. He didn't use twine to tie it, but took a corn-stalk and wrapped that around, twisting the ends and tucking them under.

Jim began to get tired, toward the end of the afternoon. Uncle David watched him a moment, and then told him he'd better rest while the others finished up. Jim shook his head. But Uncle David insisted. So Jim found a place on the sunny side of a corn shock, and sat down, with his back among the rustling, crackly leaves.

Not far away was a fence, with a tree growing beside it. After a while Jim happened to look that way and saw a squirrel come down the tree and hop over to a post of the fence. Jim kept still, watching closely, but not moving. For a time the squirrel sat there, jerking his tail and looking at Jim. Then he came down the side of the post and disappeared somewhere in a pile of rocks close by. Jim watched and waited. Once in a while he saw him again, running over the fence or scampering 
up the tree. Sometimes the squirrel sat up on the stones, and seemed to be holding something in his paws.

Finally Jim walked over to the rocks, and found little heaps of nuts and shells piled up here and there on the stones. The tree near by was a hickory nut tree, and this was where the squirrel ate his meals.

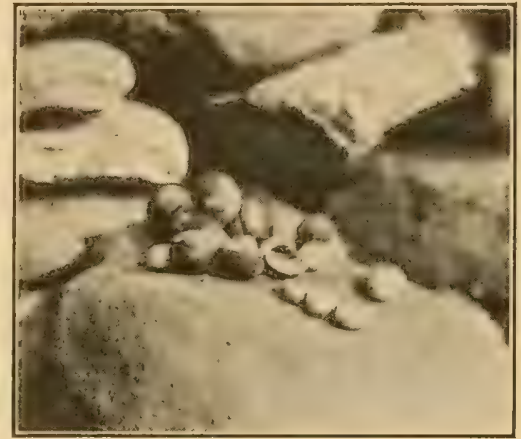

Therf, was a Heap of Nuts and SHElls

Then Horace came along, with Uncle David and Andrew following, and they all went back to the house to get ready for supper. 


\section{CHAPTER XI \\ MILK AND CREAM}

IT was Aunt Lucy who thought about the milking.

When Jim and Peggy came down to the kitchen, early next morning, they found Aunt Lucy there, getting breakfast.

"We'll have to wait for our cream," she said, "until Uncle David finishes the separating."

"Is he out in the barn now ?" asked Peggy.

"Haven't you children seen the cows and the milking yet?" exclaimed Aunt Lucy.

They shook their heads.

"Well, run on out to the barn. Andrew and Uncle David are milking now. You'll get there before they finish, if you hurry."

They raced out to the barn, back through the big middle part, and into the wing where the cows were kept.

Uncle David was sitting on a little low stool, close up beside one of the cows. Between his knees was a pail. It was not like an ordinary pail, but had a rim around the top, so that the opening 
was not so large, and it had a wide spout at one side. Uncle David was working with his hands at the milk bag of the cow, pulling down and letting go, steadily, first with one hand and then with the other. Each time he pulled down, a tiny stream of milk shot down into the pail. The cow stood pretty still, but sometimes she would swing her

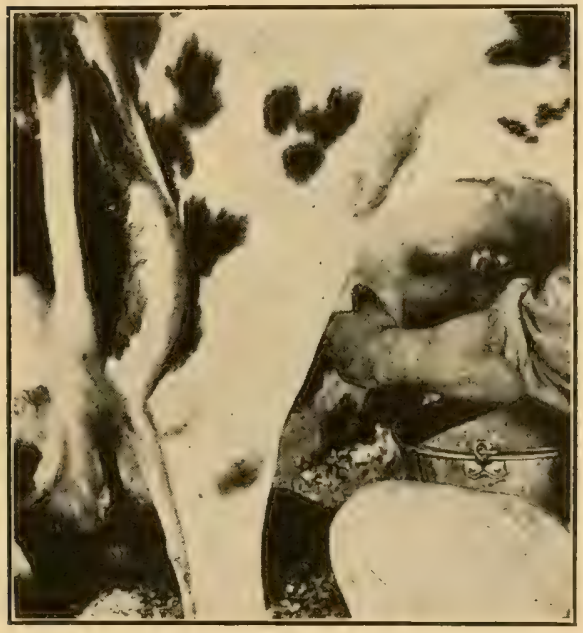

Uncle David was Miliking tail around as if there were flies to be switched off, and sometimes she would raise one hind foot. It made the children wonder whether the milk wasn't going to be spilled. They looked into the pail, and found that it was nearly full. The top of the milk was covered with white foam.

"Pretty good amount for one milking, isn't it ?" said Uncle David.

"Did you get all that from this one cow?" asked Peggy.

"Yes. She's giving this much every morning 
and evening. This is Johanna. She's a good milker, but she's apt to be a little cranky."

As if to prove that he was right, Johanna switched her tail around, and hit Uncle David across his ear.

Peter, the cat, came walking in, and sat down close by.

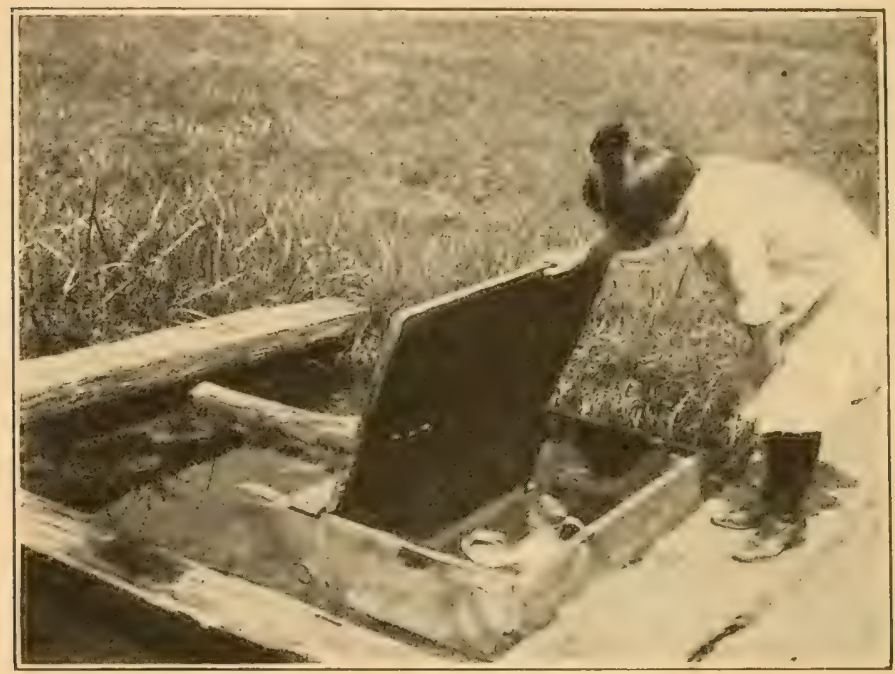

There was a Box in the Spring

"Want some milk, Peter?" asked Uncle David.

Peter took a step or two nearer, and Uncle David shot a stream of milk at his head. Instantly Peter opened his mouth, and part of the milk went straight in. Peter blinked his eyes and licked his lips.

When Johanna had been milked they went out, 


\section{MILK AND CREAM}

and Uncle David carried two cans of milk down to the spring. There was a box in the spring, placed so that the cold water came up in the box nearly to the top.

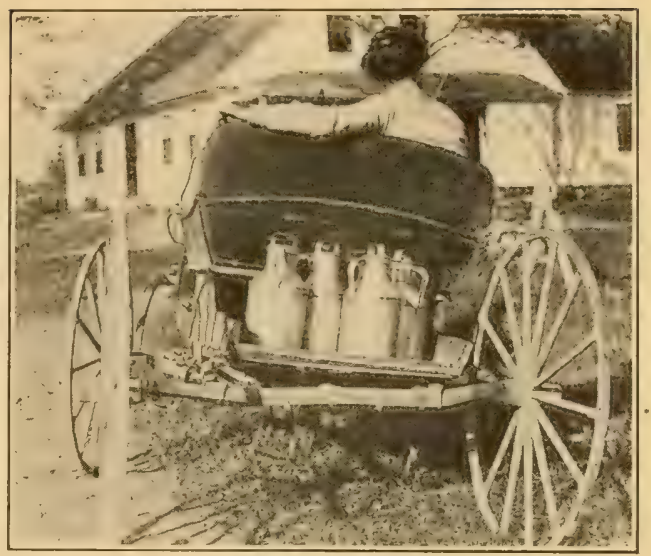

They Haul the Milk in Cans to the Railroad

The two cans went into this box. Uncle David explained that usually they had ice, from their own ice house, but this season

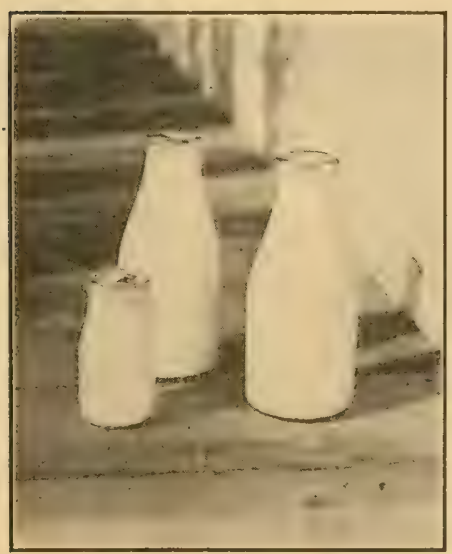

The Dealers put the Milk in BOTTLES the supply had given out and they used the spring instead.

"What do you do with all the milk, Uncle. David?" asked Jim, as they started toward the house.

"Well, one of those two cans there is for ourselves, to drink and use for cooking. The other is for some folks 


\section{JIM AND PEGGY AT MEADOWBROOK}

that live up the road. They don't keep any cows, because they come out to their place only now

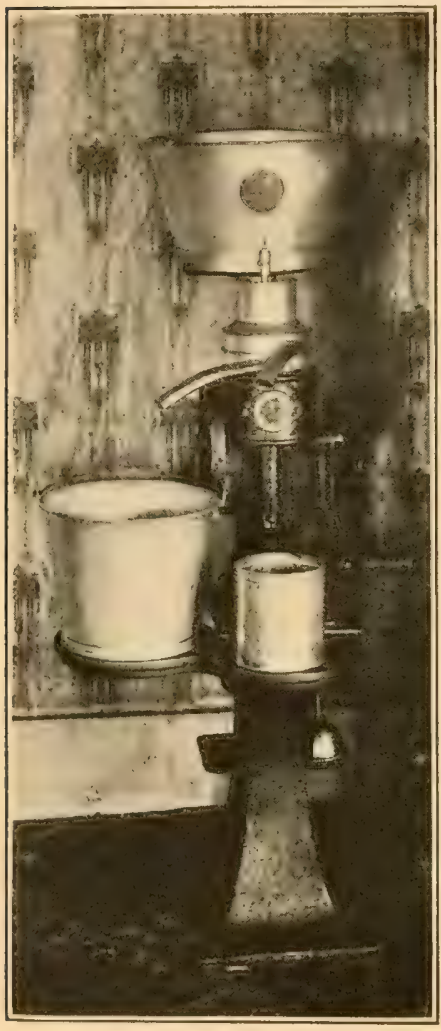

Near the Wall was the SEPARATOR and then. When they're here they send to us for the milk they need. Their hired man comes down every day. The rest of our milk we separate. That's my next job. So you can watch, if you want to."

"Do all the farmers here separate their milk?" asked Jim.

"No, only a few. Most of them send the whole milk to town. It goes in cans. Some use big cans, and some smaller ones. They haul it to the railroad at Milford every morning, and the train takes it to milk dealers in the city. The dealers put it into bottles, and deliver it all through the city to their customers. "That's the way ours comes, at home," said Peggy. 


\section{MILK AND CREAM}

They walked in through the summer kitchen, to the milk room. Andrew had carried over the rest of the morning's milking. There were three big pails full, standing on a bench.

Near the wall was the separator. It had a large pan on top, a middle part where two spouts came

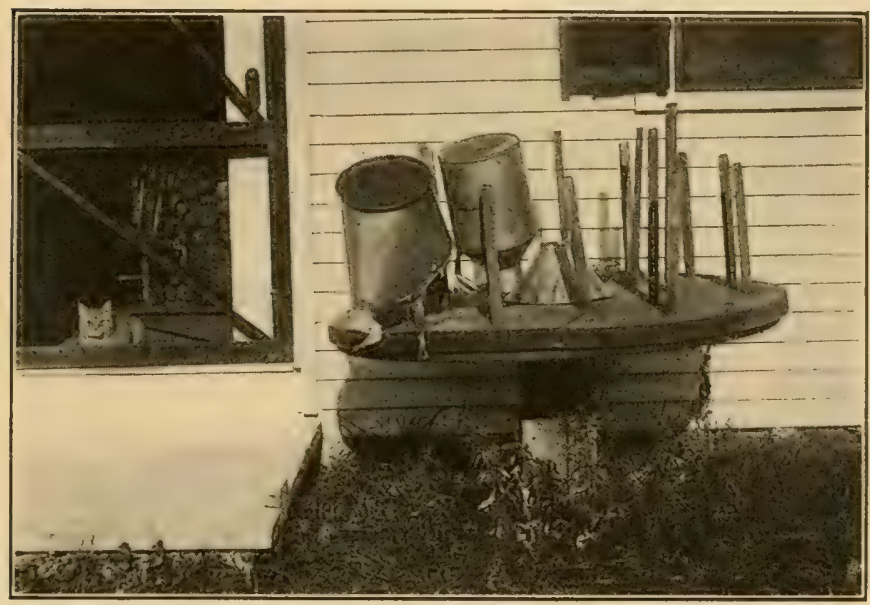

The Rack where the Milk Pails were Dried

out, and a pail and a small can beneath the two spouts. At one side of the middle part was a crank.

Uncle David set a cloth strainer over the pan on top, and poured in some of the fresh, warm milk. Next he began to turn the crank, slowly, and a humming noise sounded from the middle part of the machine. Then he opened a little 
72 JIM AND PEGGY AT MEADOWBROOK

spigot that connected with the bottom of the large pan, letting a little stream of milk flow into the middle part. In a moment another little stream

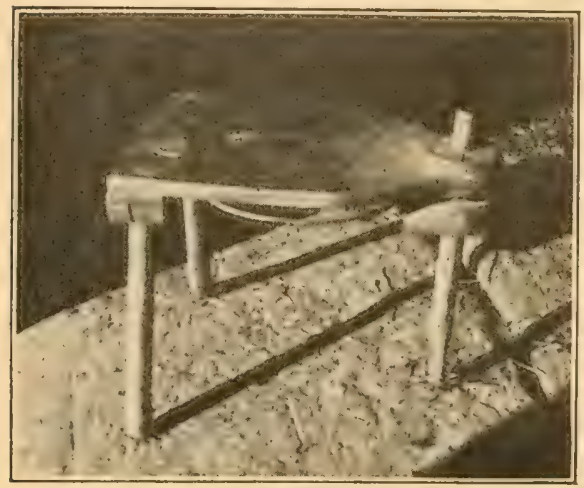

Uncle Dayid's Milking Stool began to come out of the spout over the pail, and almost at the same time a very tiny stream of yellow cream commenced to flow from the "other spout, into : the small can : beneath.

Uncle David turned steadily at the crank, once in a while pouring more milk into the top pan. As the pail of skim milk filled up, he emptied it into a big can standing near. When he had finished, the small can was nearly full of yellow cream.

Before they went to breakfast he showed them the rack outdoors where the milk pails and pans were put to dry in the sun, after they had been washed with hot suds to keep them clean and sweet. 


\section{CHAPTER XII}

HOW AUNT LUCY MADE BUTTER

ANDREw's prediction about the weather came true. Early in the morning the sun was shining. But the sky in the east had been red at sunrise, and there were dull-looking clouds that gradually spread until they shut out the sun. While the children were at breakfast, drops began to fall, and soon it settled to a steady quiet rain. Once or twice the clouds broke away, but they soon closed in again.

Andy came up in a black, rubber coat, and an old hat turned down all around. He and Uncle David went out to the tool shed to sort apples and head up the barrels. "Good thing we got the fruit picked," remarked Andrew.

"Well, here it is Friday, and butter day," said Aunt Lucy to the girls. "Time to be at the churning."

"Can we watch you?" asked Peggy.

"Yes, indeed."

Jim and Horace were sitting in the door of the woodshed, making sling shots out of forked sticks 
74 JIM AND PEGGY A'T MEADOWBROOK

and a pair of rubber bands that Horace had found. They were too much interested in what they were

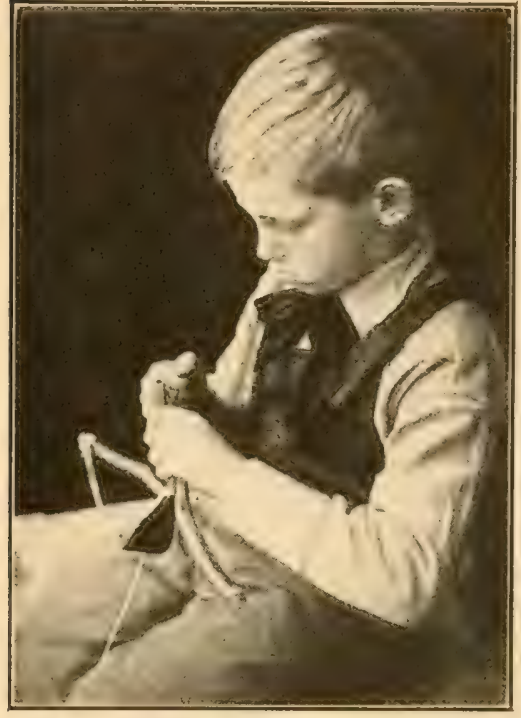

The Boys were Making Sling Shots doing to stop and watch the churning, though they came into the milk room later, to see the finish of the work.

Aunt Lucy prepared the churn. It was like an oblong box, hung from a kind of framework by iron rods. There was a handle on each end and you could swing the box back and forth. In the top of it was a square lid, with a little round, glass window in it. A fire was going in the stove, in one corner of the milk room, and on the stove was a big boiler, full of hot water. Aunt Lucy rinsed out the churn with both cold water and hot. Then she poured in the cream. There was a big can half full of it, for it had been saved up each morning and evening for several days.

Aunt Lucy sat down near one end of the churn, and started it going, back and forth. Inside of the 
churn the cream went "whoosh, whoosh," as it flowed against the ends of the box. It wasn't hard to keep the churn going. Once you had started it, just a little push each time kept it swinging. Pretty soon Peggy had a turn at it; and then Jane; and then Peggy again.

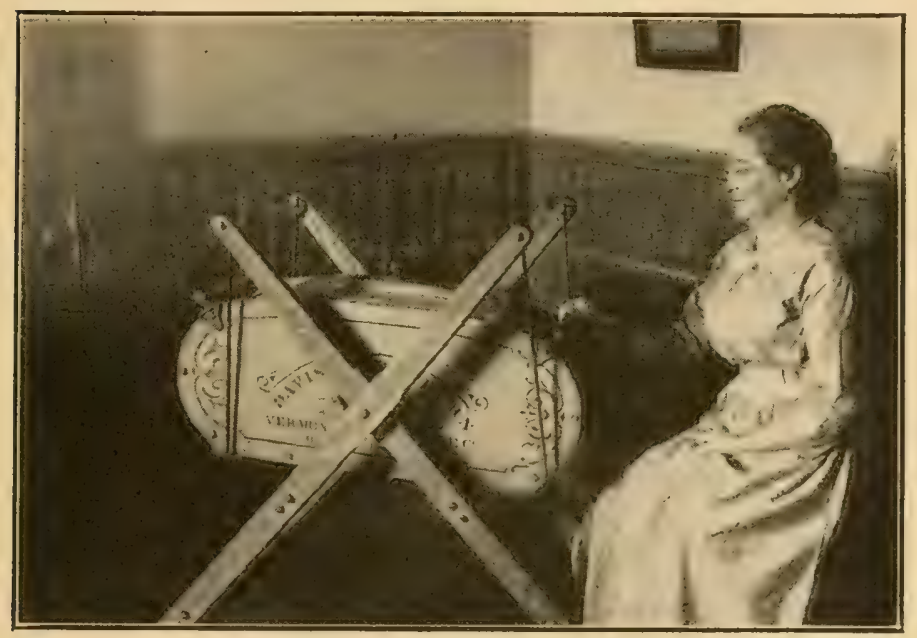

The Churn was like an Oblong Box

Gradually the noise made by the cream inside began to change. By and by Aunt Lucy unfastened the cover, and they looked in. The cream had changed to a wet, crumbly looking mass, with the yellow color of the butter showing all through it. They put the cover on again and swung the churn a little longer. 
Then Aunt Lucy stopped it, set a pail under one corner, pulled out a plug, and let the buttermilk drain out. When it ceased running, she put in the plug again,

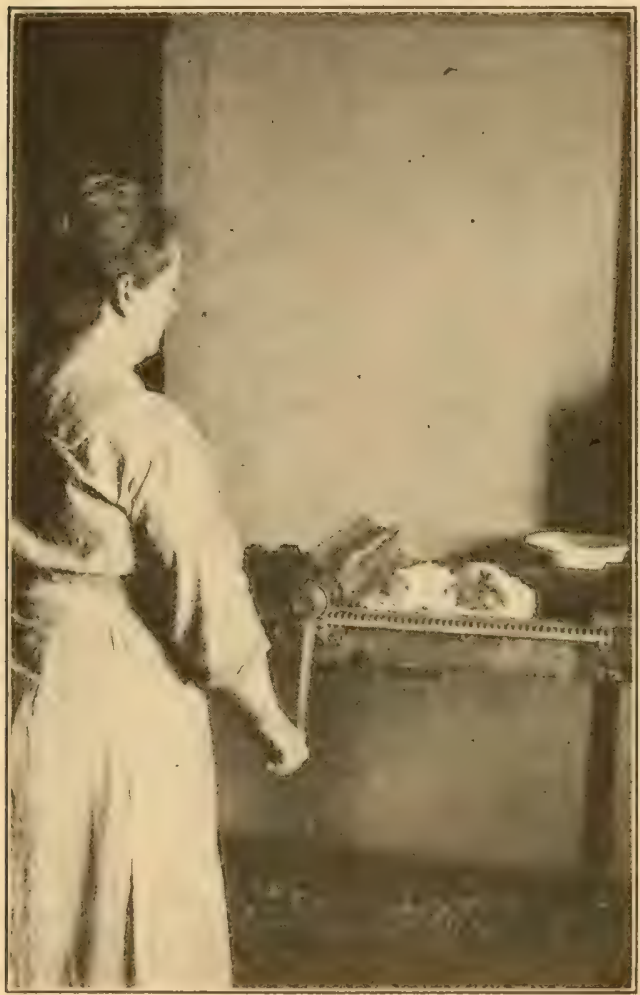

The Ridges on the Roller Sank into the BUTTER ()pened the cover, and pozired in a pail of cold vater. The churn was set $\mathrm{s} w$ i $\mathrm{n} \mathrm{g}$ i $\mathrm{n} \mathrm{g}$. Then it was stopped and the water was drained out. This was done over again three or four times, until the butterwas washed clean of any buttermilk. When the $\mathrm{g}$ ir $\mathrm{ls}$ looked in again they saw a handsome golden yellow heap in the bottom of the churn. On a table close by was a shallow box with a 
roller over it that you could run back and forth with a crank. The roller had ridges on it, from end to end. Aunt Lucy took two paddles, one in each hand, reached into the churn through the hole in the top, and lifted out a mass of butter, holding it between the two paddles. She put this into the shallow box where the roller was. Two or three more heaps of butter were added in the same way. Then she ran the roller back

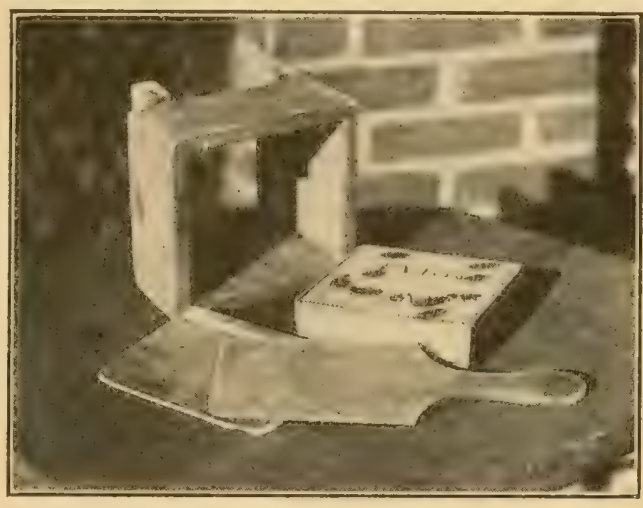

The Bottol of the P'Rint-box COUld be LIFTED OUT and forth. The ridges on it sank into the butter, spreading it out the length of the box.

Next she sprinkled salt over the butter, and then with the paddles she turned the ends of the mass back over the part in the middle. Again the roller was run back and forth. Several times the butter was heaped up in the middle, and each time spread out again with the roller.

Now Aunt Lucy was ready to make the prints. She took out of a pan of water a little square print-box. The bottom of it was a block of wood 
78 JIM $\Lambda$ ND PEGGY AT MEADOWBROOK

that you could lift out. With a paddle and a flat, wood scraper Aunt Lucy filled the print-box full of butter, scraping it off level. Then she turned it upside down and lifted off the box. The

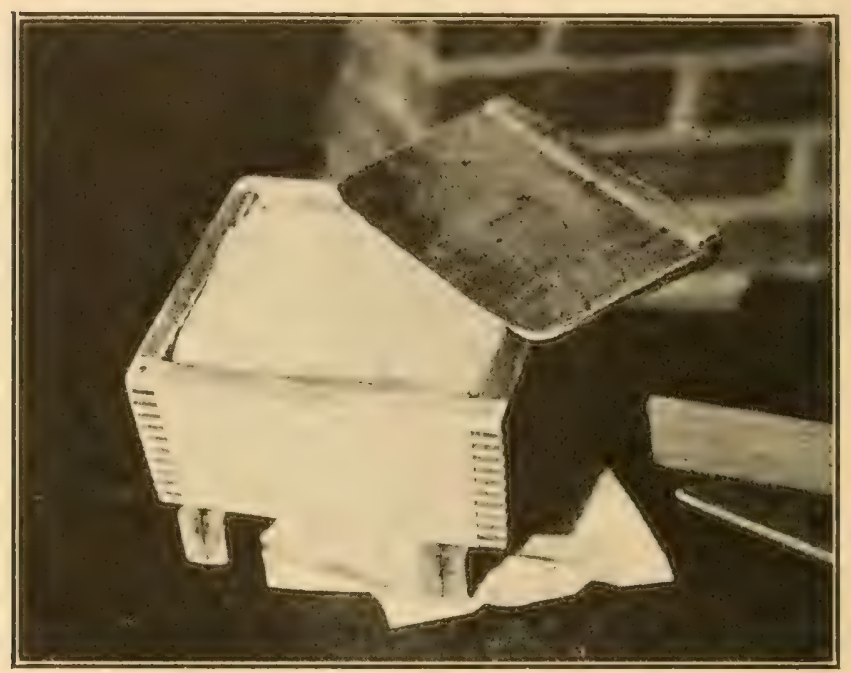

Aunt Lucy Filled the Print-Box with Butter

wooden block was left on top of the butter. This came off next, - and there was the golden yellow print.

Later they wrapped the prints in squares of parchment paper. When all were finished, Jane and Peggy put them in a basket, carried them to the spring, and packed them away in a big crock that was waiting for them, inside the spring-box. 


\section{CHAPTER XIII}

IN THE BARN

When Horace and Jim had finished making the sling shots, they picked a chance between showers and dodged out to the barn. There was good s p a c e out there to try them. Also there was a supply of ammunition in the shape of corn - which wasn't always accurate, but couldn't do any harm.

They hung up a tin can in the open

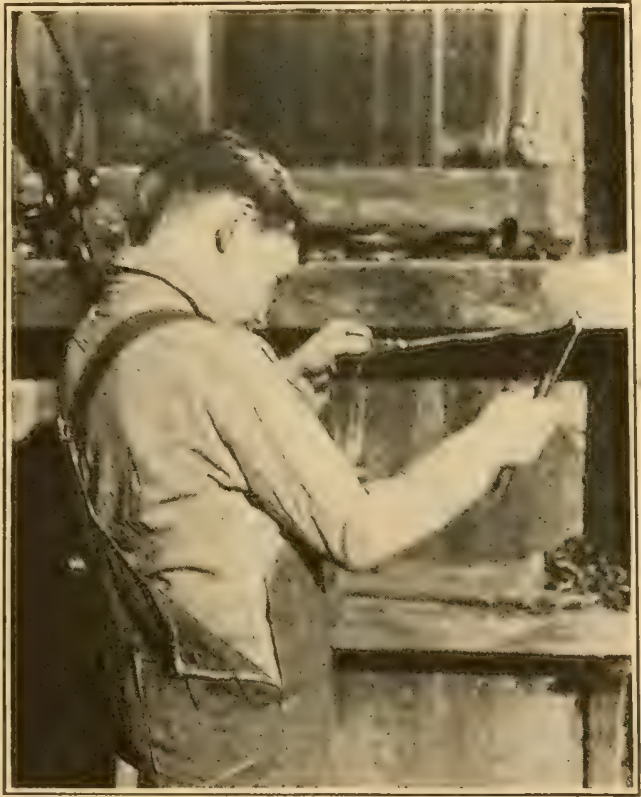

They Began to Pepper the Can barn door, got a supply of corn from the barrel, climbed up into a wagon that stood half-way back 
in the barn, and began to pepper at the can. Usually the corn would go straight enough, but sometimes it swung around in a curve, so that it didn't go anywhere near the can. After a little Andy came up to.the door, when they weren't looking for him. "Good thing that's only corn you're shootin'," he laughed.

Then two or three turkeys came draggling along

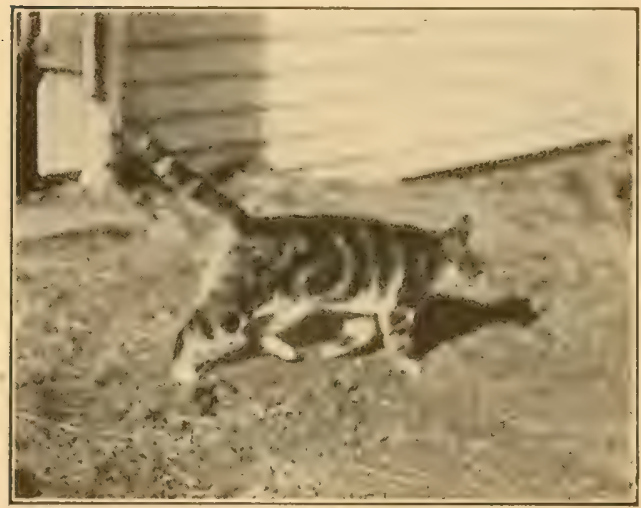

Peter Stuck his Tail Straight up in the wet and began to find the grains that had scattered here and there in front of the barn door.

"Bet you can't hit a turkey," said Horace.

Both boys tried it. But the turkeys were too far out in front of the barn to get hit very often, and they didn't mind it, anyhow. They merely went on walking around, eating the grains as fast as they could find them.

Pretty soon Peter, Jane's cat, came walking out of the tool room, where he'd been watching for mice. Neither boy said anything to the other, but each sent a grain in Peter's direction. It 
couldn't hurt him; but it did surprise him. He stuck his tail straight up, made about two jumps, and disappeared out of the barn door.

After this there was nothing more to shoot at, except the can again.

"Let me tell you what you'll get for supper," said Horace.

"How d'you do it ?" asked Jim.

"You take a handful of corn," explained Horace, "and I say a rhyme with things to eat in it. Each time I name something to eat, you take one of the grains of corn out of your hand. Then the thing that comes with the last

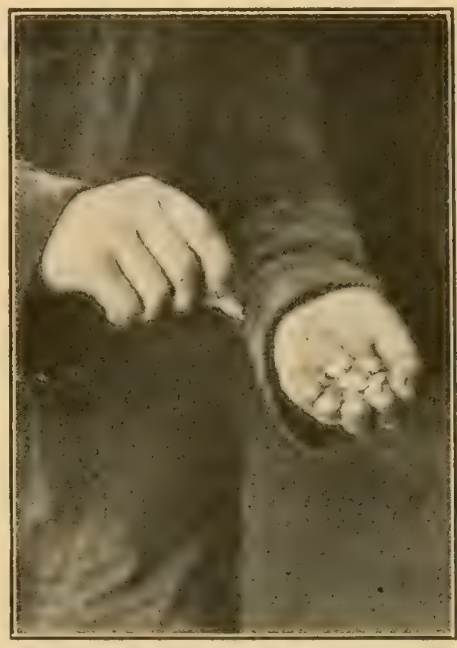

Whatever Comes Wi mi the Last Grain grain is what you're going to have for supper. See?"

Jim got a handful of corn, and Horace began.

"Apple pie, pumpkin pie, blackberry jam, A spoonful of paint on a little piece of ham.

Whatever I say with the last grain of corn You'll have to eat for supper as sure as you're born.

Fresh bread and butter, and custard in a bowl, An old, fuzzy coat, and a black chunk of coal. 


\section{JIM AND PEGGY AT MEADOWBROOK}

Roast potato, chicken wing, hot cross bun.

When you eat what's coming, we'll have a lot of fun.

Ice cream and cake, and a big bale of straw,

A bull-frog's leg, and a pollywog's paw.

A dish of plum pudding, and a yard of garden hose, An old, wooden Indian, without any nose.

Woolly worms, wiggly worms, Ugh! - Think of that ! The end of the tail of our old tom cat.

If my rhyme is finished before the last grain,

I'll have to eat 'em all myself, and get an awful pain.

A red, juicy apple, and a nice, sharp axe, A handful of dirt, and a paper full of tacks.

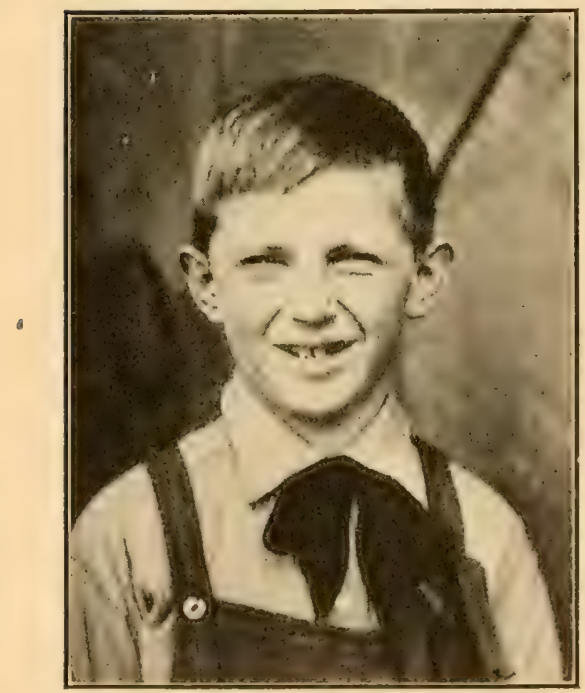

"A Paper full of Tacks" for Supper
A stuffed, sawdust puppy, and an old rubber ball -

There's no more in the cupboard, so I guess that's all."

Horace didn't get to the end of the rhyme, though. Jim's last grain of corn came when Horace said "a paper full of tacks." So Horace declared that Jim would have to eat them, when supper time came. 
The next hour they spent in the haymow, sliding down the slippery heaps of hay, jumping from one place where the hay was piled high to another where it was lower, and examining an old swallow's nest in the gable end of the barn. By that time

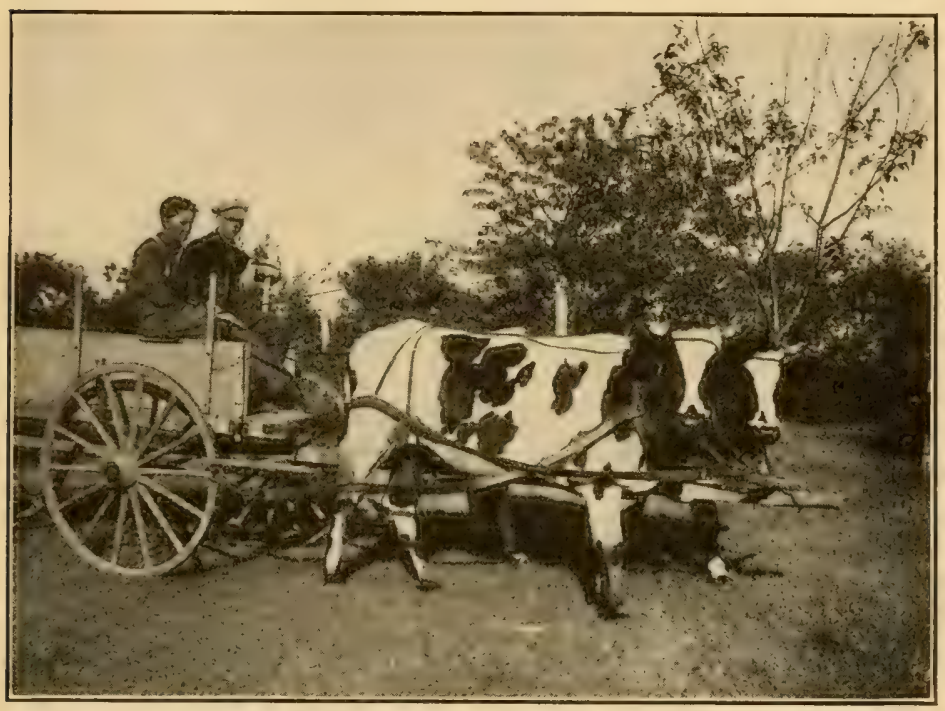

The Boys Hitched up Eli and Aaron

the weather had cleared off, and the sun had come out.

Henry Reynolds and his little brother Sam came over from their place on an errand. Henry was two years older than Horace. Jane and Peggy wanted to see Eli and Aaron hitched up. So the boys got the two steers, put the harness on them, 


\section{JIM AND PEGGY AT MEADOWBROOK}

hitched them to a wagon, and drove them around the yard.

The sky was so clear by this time that it seemed certain that the rest of the day would be fine. Horace hunted up his father, and came back in a few minutes with permission to take Jim, after dinner, and go fishing. Before Henry left they got a spade and a tin can, and Henry helped dig a lot of fishworms for bait. It was easy to get them, after the rain. 


\section{CHAPTER XIV}

\section{THE FISHING TRIP}

THE boys hustled through their dinner, and were soon ready to start. Uncle David offered them a

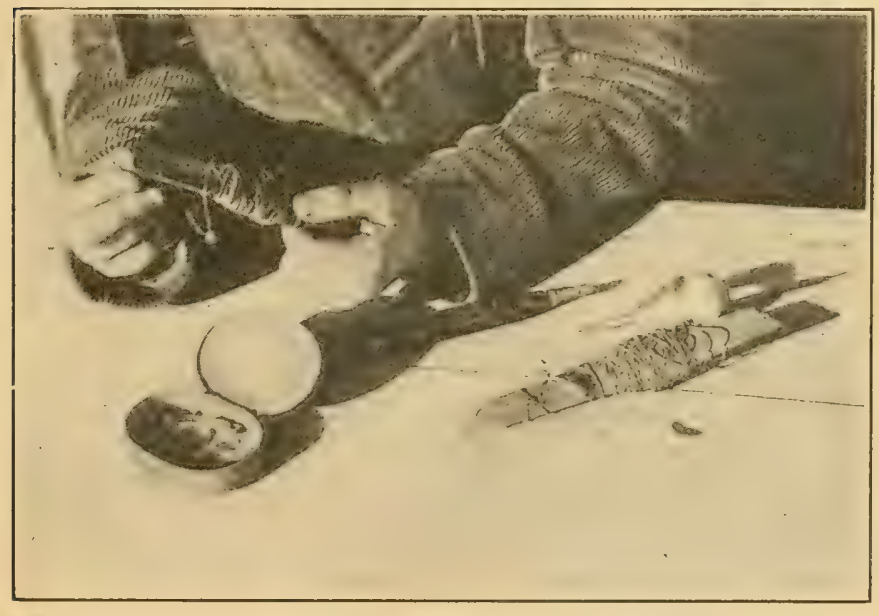

- Horace got out the Fishlines and Corks

fish basket and a jointed pole to take along. But Horace didn't want to bother with them. "We'll cut our poles," he said, "won't we, Jim. And if you take a basket, you won't get any fish."

From a box on a shelf in the woodshed he got 
86 JIM AND PEGGY AT MEADOWBROOK

out two fishlines, wrapped around pieces of shingle. There was a hook and a sinker already fastened on each line. Then he laid out two corks. Each boy stowed his outfit away in a pocket. Horace

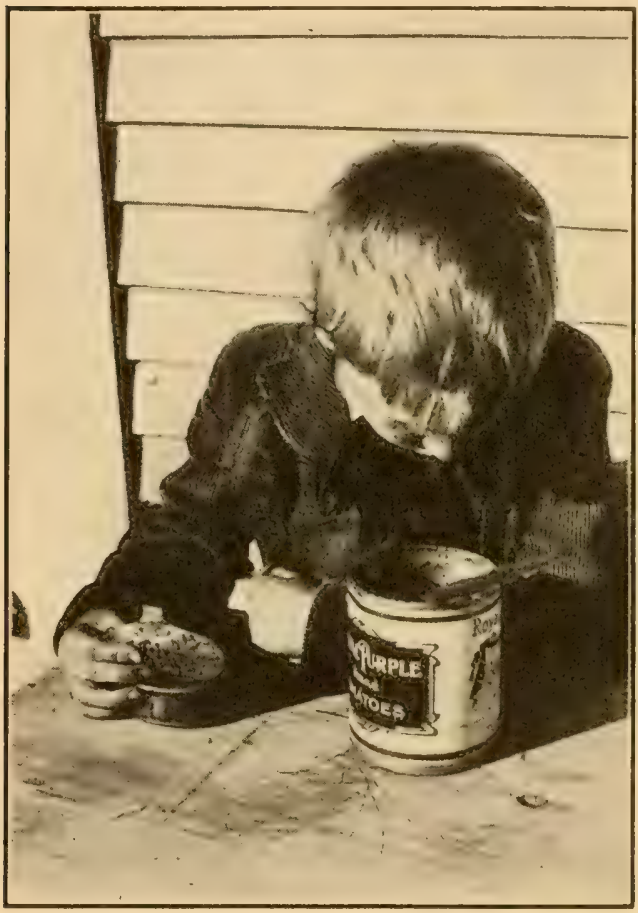

He pUt the Fishworms in a Bait-can had some extra hooks and sinkers and a stout cord in a small, tin box, and these he added to his outfit. The fishworms he took out of the empty to$m$ a to can, where Henry had put them, transferring them to a small can with a lid so that he could carry them in another pocket.

"Which way are you going?" asked Uncle David. "Down the brook," said Horace. "Guess we'll go to the pond where the old mill used to be." Horace tried to find Spot. But Spot had gone 
visiting again, over'at Tag's, so he missed the trip. The boys went out the lane, cut across through the back field, climbed a fence, and came out on the farther side of a little wood. The brook was in a meadow, below them to their right, beyond a wire fence.

They started toward it. Before they had gone

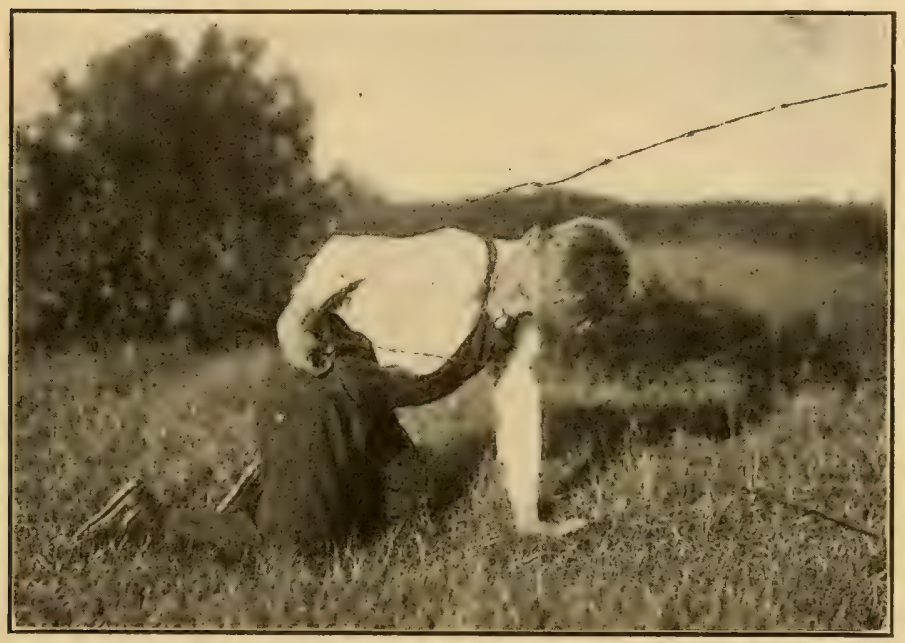

Jim's Overalls Caught on the Barbed Wire

halfway there was a queer noise behind them, up the hill, and something snorted.

"Come on, Jim," yelled Horace.

In an instant both boys were running down the hill as fast as they could, toward the fence. Once Jim slipped, and fell flat with his heels up in the air. But he was on his feet again, almost before 
he knew he had fallen. Horace dived under the fence, with Jim close after him. It was barbed wire, and as Jim went under he caught his overalls on one of the barbs. He pulled loose, scrambled through and caught again as he got up on the other side.

Horace was staring up the slope, with a disgusted look on his face.

"Shucks," he said, "I thought it was Simpson's

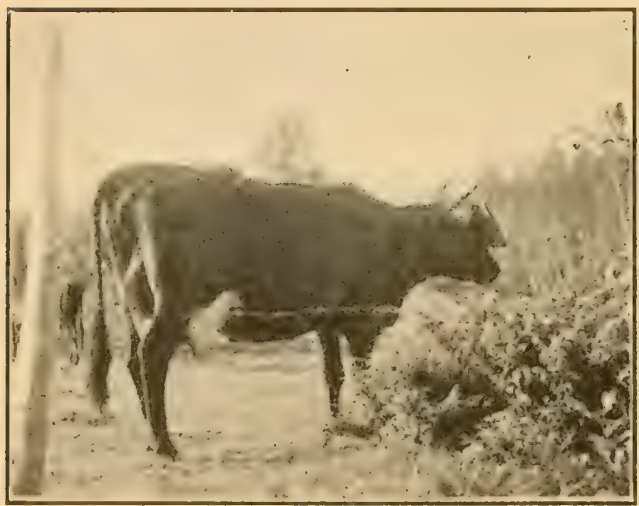

A Board was Fastened over hêr Eyes

"Oh, she tries to," said Horace, " bull and it's only his crazy, old, black cow."

Sure enough, there she was, trotting down the slope tow a $\mathrm{rd}$ th e fence.

"Was she chasin' us?" panted Jim. "but you see Simpson has that board fastened on her head, in front of her eyes. When she puts her head down to run after you, she can't see you any more. She can't hurt you.'

They walked on down the bank of the brook, leaving the black cow standing beyond the fence. 
Pretty soon Jim found a wooden sign fastened to a rough post. Its letters were almost gone, but Jim managed to make out that it was a warning not to fish in the brook.

"Oh, that doesn't count," said Horace. "This is Mr. Taylor's field, and he wouldn't care about us. Anyhow we're going on down to the old mill."

Before they reached the pond Horace decided they'd cross to the other side of the brook. Jim found a place where an old plank had lodged on some brush, and he stepped on it to try it. But the farther end slipped off into the water. So they went on to another place that Horace knew about, and crossed on a fallen tree.

Just below, the brook widened out to form a pond. Horace led the way to a spot on the bank where he had fished before. There were three or four rough poles leaning against the bushes. One 
of them Horace had cut on another trip. They tied on their lines, baited the hooks, fastened on the corks about three feet up from the bait, and sat down to wait for bites.

For a long time the corks floated without a sign. Sometimes they would drift in to shore, and the boys would lift the poles and swing the lines out farther again. Once a muskrat came swimming across the pond toward them. But he caught sight of them and dove, and they did not see him any more.

After a while something made Jim's cork jiggle. He jerked up, but there was nothing on his hook. As soon as he dropped it in, it began jiggling again. "That's shiners," said Horace. "They'll eat your bait off. They're so little you can't catch 'em."

Pretty soon they began nibbling at Horace's hook, too. Each boy had to put on new bait, several times.

Finally the boys moved to a new place. But there weren't even any shiners there. So they left the poles with the ends braced under roots and the lines in the water, and went to explore the old, tumble-down mill.

While they were sitting on the stones that had once been part of the milldam, a fish jumped, in the water below them.

"See that?" said Horace. "Let's try it here." 
They took up their poles, and found that shiners had cleaned their hooks bare. Each boy picked out an extra big worm, and baited up. Horace grinned, and spit on his bait.

"Bet I catch one, now," he said.

But the corks still floated idly around.

Then when Horace was wondering whether to try another place before they went home, his cork suddenly sank out of sight. He jerked up on the pole - a nd h is line flipped up into the air - empty.

At that moment Jim's

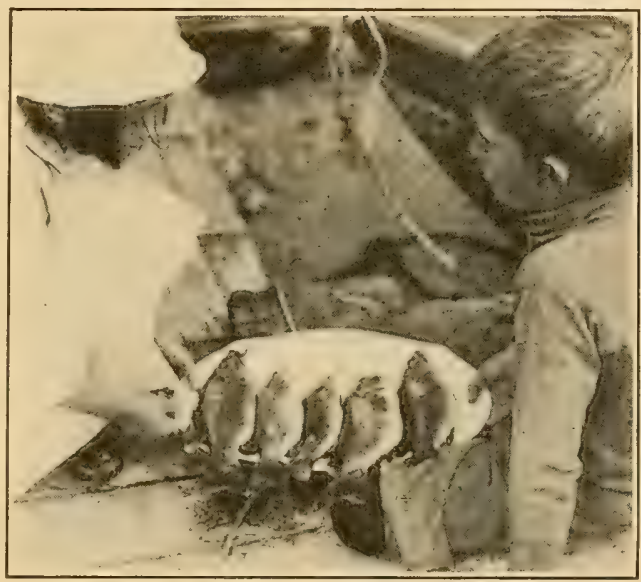

Horace Caught Three and Jim Caught Two

cork went down. Jim jerked, and swung a flashing, wiggling fish out on the bank. They both scrambled up. Soon they had their capture strung on the heavy cord that Horace had brought. In a few minutes the boys had three more; two for Horace and one for Jim.

For a long time, then, they waited. Finally Horace caught another. But after that neither could get any more bites. 
By that time it was nearly sundown. Neither boy was ready to leave; but each was getting hungry. They untied their lines, fastened the string of fish to the middle of one of the poles, and tramped home.

At supper Uncle David suggested a plan for the next day. He would need to make a trip to Freeport, a large town about seven miles from Meadowbrook Farm. On the way back he planned to drive around by Milford, to let big Dan have a visit at Old Tom's blacksmith shop. The plan was that Horace and Jim should go along. The boys grinned and looked at each other. Evidently the plan suited them.

"Mind you, boys," said Uncle David, "you'll have to rustle out early in the morning. It's a long drive, and we can't make such good time with Dan as we could with Milly." 


\section{CHAPTER XV}

\section{ON THE WAY TO FREEPORT}

IT was hardly daylight when Uncle David called them next morning. The boys hurried through breakfast and a little later they were ready to start.

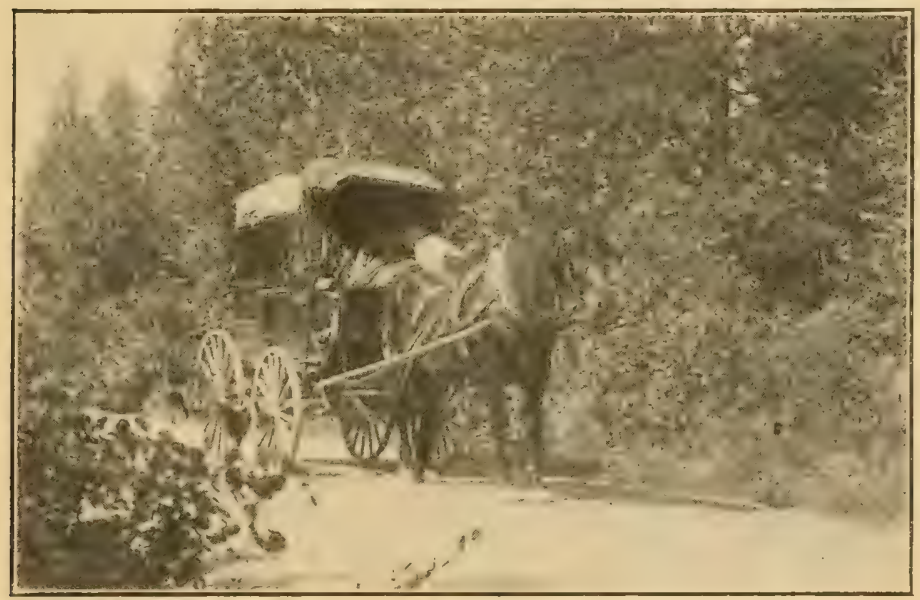

Around a Bend they Met a Peddler's Wagon

Dan was hitched to a light farm wagon. In the wagon bed were three or four boxes, covered with a piece of heavy canvas that was tied to the back of the seat and the rear end of the bed. The boys and Uncle David just filled up the seat. 


\section{JIM AND PEGGY AT MEADOWBROOK}

They drove down the lane, turned into the highway, rattled across the bridge, and climbed the long hill. Around the bend at the top a funny

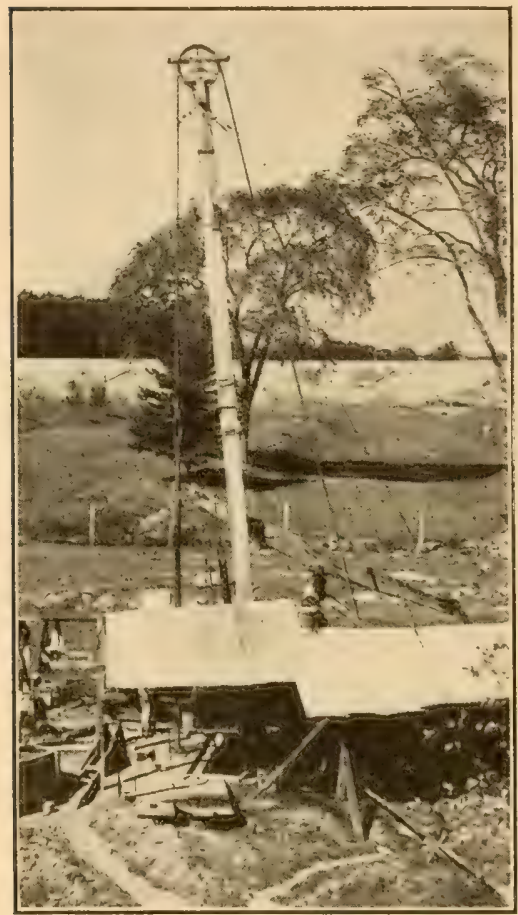

Near a Barn was a Well Drill looking wagon came into view.

$$
\text { “' M or n ing, }
$$
Jacob," called Uncle David, as the wagon drew near. "You've made an early start this morning."

Jim looked at the wagon in wonder. It was built high up in back and had doors and drawers everywhere.

"He's a peddler," Uncle David explained to Jim, when Jacob had passed. "He comes around every month or so. You'd be surprised to see what he has in that wagon: pretty nearly everything from clothespins to dresses. He'll stop at the house. It's handy to have him come around. Usually there are things that we're out of, and we can get them of him. Everybody buys of him.' 
They drove on down past the schoolhouse and into the Freeport road. Beyond the corner was a tall, wooden derrick near a barn. Jim asked what it was for, and learned that it was a well drill. The men were just beginning the day's work, so

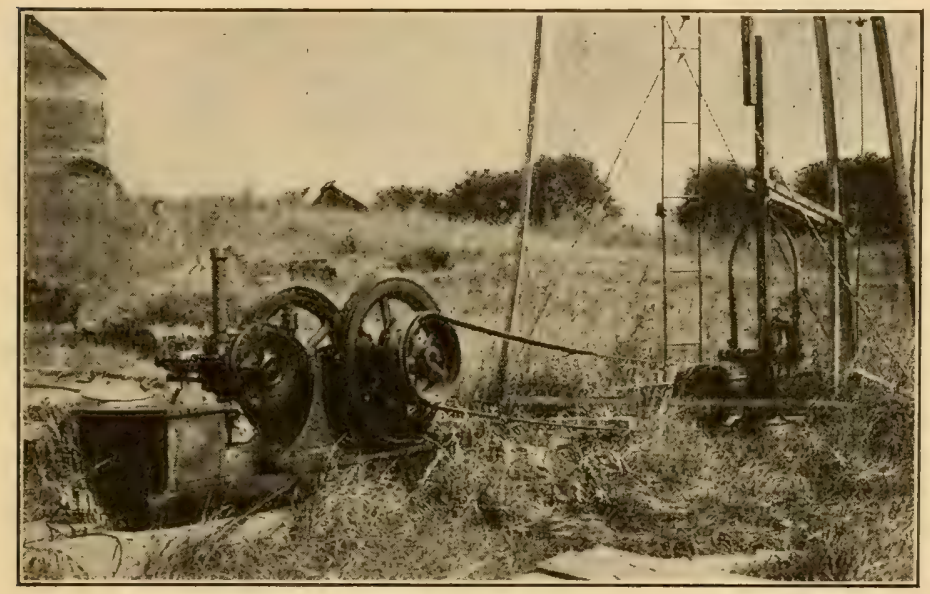

Jim had Seen a Gasoline Engine Fastened to a Pump

Uncle David stopped a minute to watch them start up.

There was a steam engine under a shed next to the derrick. A heavy rope ran from the shed, over a big pulley on top of the derrick, and down on the other side. On the end of it was a long piece of steel. This was the drill. Soon the men lowered this down into a pipe that disappeared in the ground.

Then the engine started up, and the rope began 


\section{JIM AND PEGGY AT MEADOWBROOK}

to move back and forth over the pulley, raising the big steel drill, and letting it come down again.

Uncle David explained

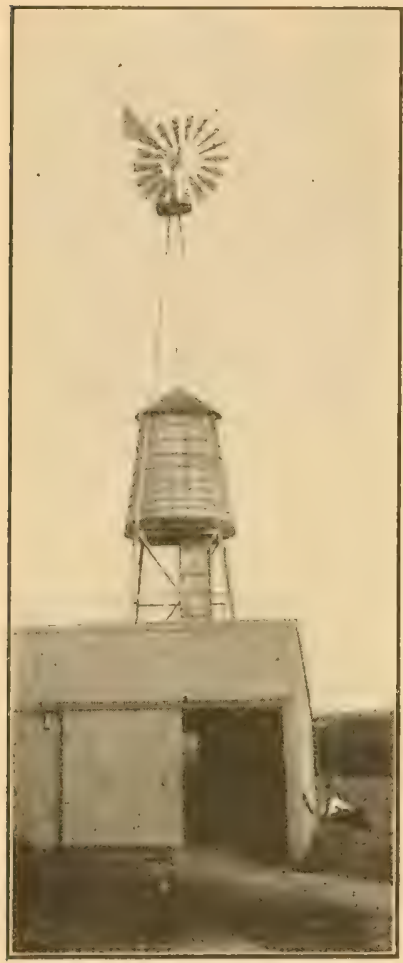

THERE WAS A TINK BetLT IN THE ToWER that they would drill on into the ground that way until they struck water. Then they would put in a pump, and perhaps a windmill, or a gasolene engine to run the pump.

Before they came to the schoolhouse Jim had seen a gasolene engine fastened to a pump. It was close to the road, beside a house near the top of the hill.

A little farther on they came to a tall windmill, standing back of a farmyard. There was a tank built in the tower of the mill.

"Does each farm have a well ?" asked Jim. "Yes," said Uncle David.

"That is, unless it has a good spring, like ours. You see, we can't have a water supply in the country like you have in the city. It would be too far to run pipes to each house, even if you 
had a big pumping station somewhere. Each farm has to provide its own water. Of course not all of them have a mill or an engine to do the pumping. Lots have just an open well, with a hand pump or a bucket, and they must carry the water into the house or wherever they want to use it."

"There's a funny building at the second place from here," he continued. "You'll see it' pretty soon. The next place is Sturtevant's. He keeps a lot of cattle, and has an iron cow for a weathervane, on top of his barn."

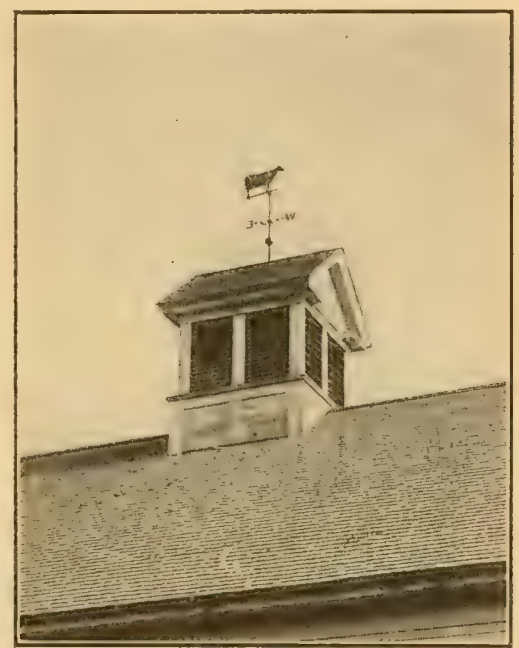

An Iron Cow for a Weathervane

"Why do you have weathervanes?" asked Jim. Uncle David turned to Horace. "Why do we have them, Horace?" he said. Horace looked surprised.

"Guess it's to tell us which way the wind blows," he suggested.

"Well," said Uncle David, "I think it's a little more than that. It helps the farmer to tell what 


\section{JIM AND PEGGY AT MEADOWBROOK}

the weather's going to be. When the wind blows this way or that, and when it switches around or blows steady, or changes from one way in the morning to another after dinner, it all means something. I suspect that's the reason we call them weathervanes. And you know the weather means a lot on a farm. Pretty much of every day's work depends on the weather."

After a little they came to the building that Uncle David had spoken of. It was a round barn - as round and smooth as a haystack. Uncle David explained that it was built that way because it had the most room in it for the least amount of lumber. But most farmers didn't like it, because it was hard to arrange the stalls and other things inside.

There was a covered wagon with a white top in front of the house opposite the round barn. The back curtain of the wagon was raised, like an awning. A man in a white coat was standing under it, showing something to a woman who had come out of the house.

"There's Steve," remarked Horace. "He didn't come around our way last week."

"He's the meatman," said Uncle David to Jim. "He drives around to the farms and brings them fresh meat. It's pretty convenient. And you can always see what you're getting."

He looked at Jim a moment. "Does a meat- 
man come to your house at home, Jim?" he asked.

"Yes," said Jim, "there's one comes every day."

He thought a moment, and then added, "Buí he brings only the meat that you've ordered."

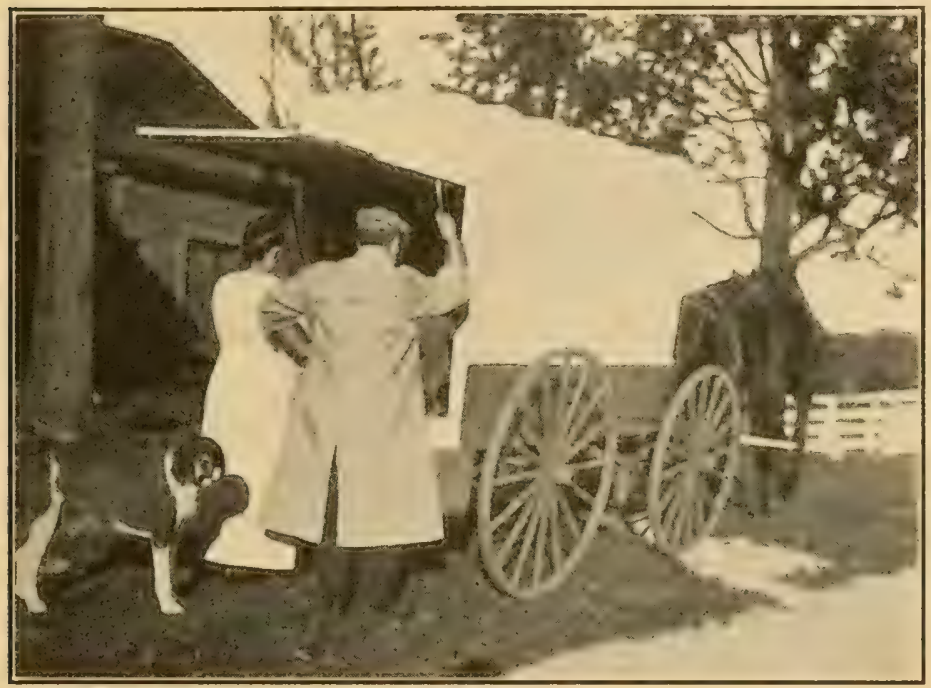

A Covered Wagon Stood in Front of the House

As they came in toward Freeport they passed a fine-looking farm, with many white-painted buildings, all neat and in perfect order. Uncle David pointed to it as they drew near. "Pretty nice place, isn't it, Jim ?" he said.

Jim nodded his head. He was thinking that he'd like to own a place like that. 


\section{CHAPTER XVI}

\section{THE WOODPILE}

WhEN they arrived at Freeport, Uncle David began delivering the things that were in the boxes in the back of the wagon. He drove to different houses, here and there. At nearly every place he left two or three of Aunt Lucy's butter prints, done up in the parchment paper. Sometimes he carried in eggs, in a basket, and at two or three places he delivered a dressed chicken.

"These are our regular customers," he explained to Jim. "We go Saturday of each week. That way, you see, we get more for our butter and eggs than we would if we shipped them on a train to the city."

Next they drove to two or three stores where Uncle David bought a can of paint, and a coil of rope, and other things. At the last place he carried out to the wagon two heavy bags labeled "Cottonseed Meal."

"That's for the cows," he said.

Then they started for Milford, to visit Old Tom's blacksmith shop.

After they were out in the country again they 
met a man driving toward town with a load of wood. He reined in his horses as they came up, and Uncle David stopped, too.

"How are you, Ned?" he said. "Hauling wood to the brickyard?"

"No, this is for Doctor Eaton."

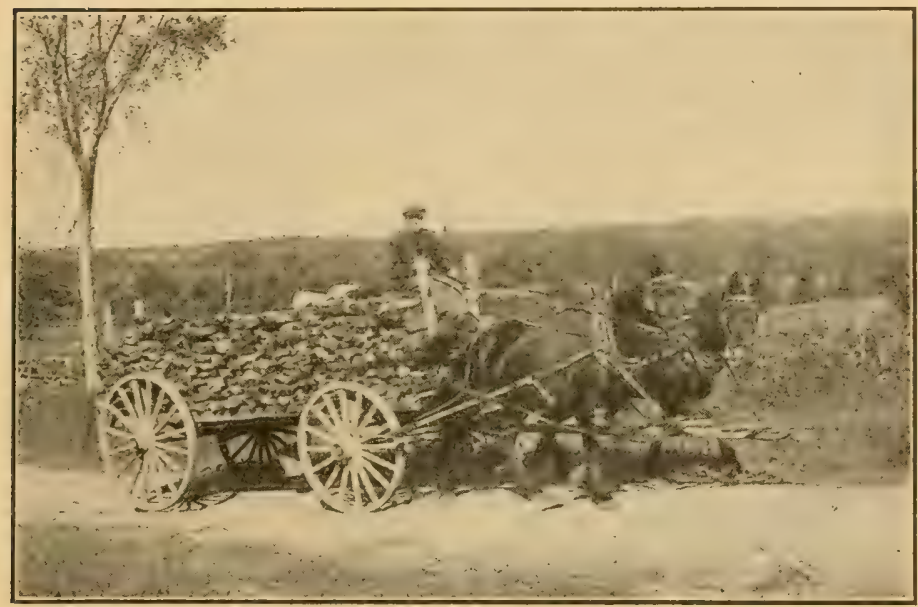

They Met a Man with a Load of Wood

"What's it worth now?" asked Uncle David. "I'm getting four fifty for this," said Ned. "Not much in it at that, is there?" remarked Uncle David.

They drove on by, Ned's horses straining in the harness to get their heavy load started.

"I'll show you in a minute where he's hauling from," said Uncle David to Jim. Shortly they 
102 JIM AND PEGGY AT MEADOWBROOK

came to a place where there had been a grove. The trees had been cut down. You could see the stumps all about. Here and there were piles of

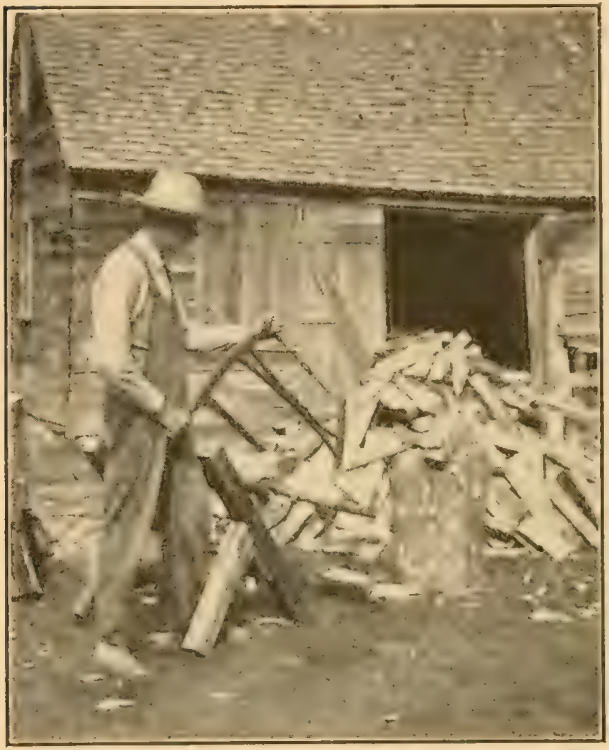

A Farmer was at Work with a Buckgaw cordwood, like: that on Ned's wagon. Each pile had sticks braced at the ends to keep the wood from rolling down.

"Did you ever saw up any cordwood, Jim?" asked Uncle David.

Jim shook his head.

Uncle David turned to Horace. "How about it, Horace?" he asked. "Would you like the job?"

"I wouldn't mind, with a gas engine saw," said Horace.

"No, I mean with a bucksaw," contended Uncle David.

"But nobody uses a bucksaw any more," Horace insisted. 


\section{THE WOODPILE}

"Some folks do," said his father. "There's a man over there now, sawing with one."

The boys looked, and saw a farmer working near his woodpile. He had a stick of cordwood laid across a framework, and was cutting it into

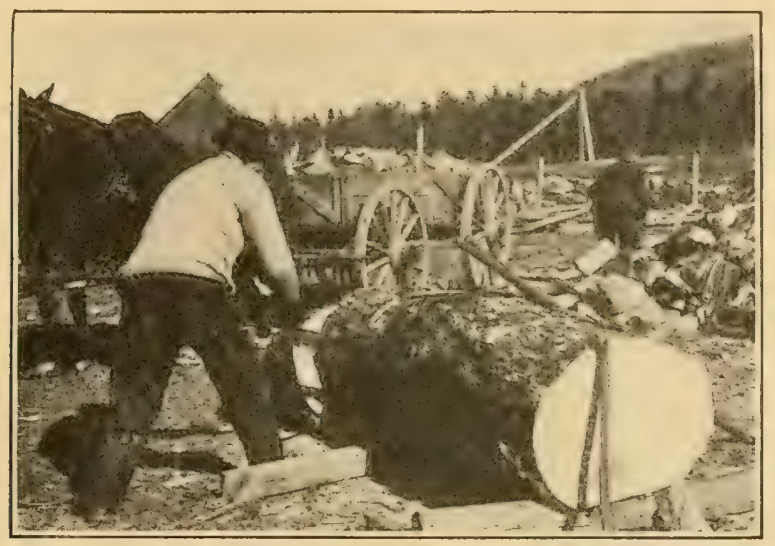

A Man was Sawing a Big Log

lengths with a saw that had a narrow blade held in a sort of wood square.

Before long they came to another farm where there were big, gnarly logs in the yard. A man was cutting one of these in two with a long, steel saw that had a straight handle at one end.

"Haven't seen any gas saw yet, Horace," laughed Uncle David.

"Does everybody use wood in the country?" Jim inquired. 
"No. There are many farmers now that use coal. But I like the wood best, and so does your Aunt Lucy. It's cleaner, and we think it makes a better fire. Besides, we have it on the farm, and don't have to buy it, as we would coal. You see,

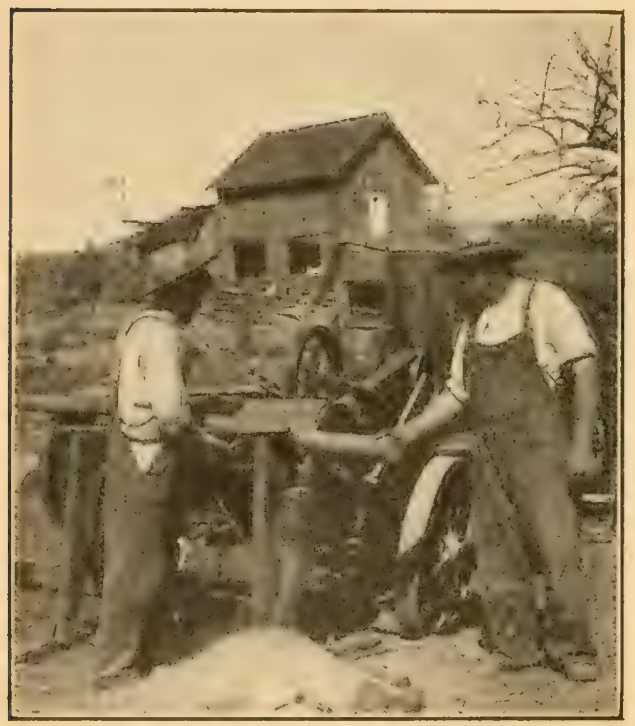

They Came to a Gas Engine Saw a good many farms have timber growing on them somewhere. If they manage it right they can cut what wood they need each year, right on the i $r$ ow place."

They came, after all, to a gas engine saw, just before they arrived at the blacksmith shop. You could hear the engine "bang, banging" long before you could see it, while in between you could hear the loud hum as the saw cut through the wood.

The engine was fastened on a heavy framework. A belt ran from it to a pulley. The saw was round, and went so fast that it looked like a 


\section{THE WOODPILE}

smooth, shining disk of steel. It took only a few seconds to cut a stick of cordwood into short lengths.

"That's a good deal easier work, isn't it?" said Uncle David. "The engine does the hard part. There are many things on a farm, nowadays, that a gasoline engine can do for you." 


\section{CHAPTER XVII \\ THE DRIVE HOME}

Old Tom was out in front of the blacksmith shop, fitting shoes on a white horse that was hitched

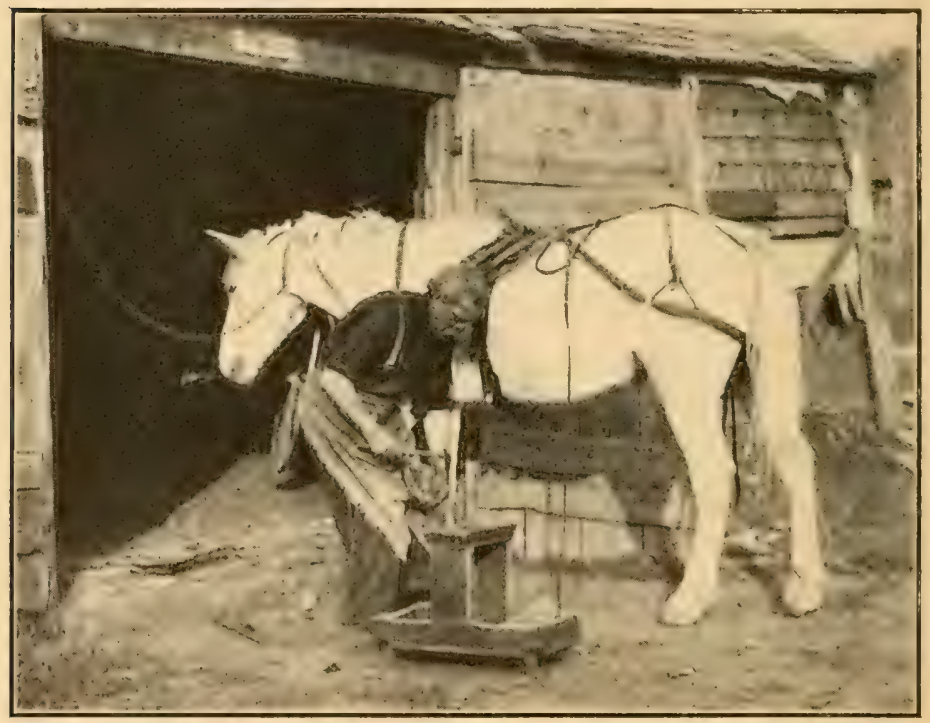

Old Tom was Fitting Shors on a White Horse

to a ring by the wide door. The boys jumped down from the seat. Uncle David unhitched Dan, and tied him to another ring, at the other side of the door. 
Close at hand by Old Tom was his queer box for tools. There was a wide lower part, in which were hammers, pincers and a big, rough file. Above this was a smaller part with partitions in it. In this were smooth, new horse-shoe nails. On the side of the box was a leather loop, inclosing a thin, curved knife with a bone handle.

The horse was standing on three legs. Old Tom bent over, close to his shoulder, and held the hoof of the other leg across his knee. He tested the shoe all around, to see if it fitted, and smoothed off the hoof a little with his rasp. Then he drove in a nail, with short, quick taps and bent the point of the nail over where it came out. Other nails were driven in and

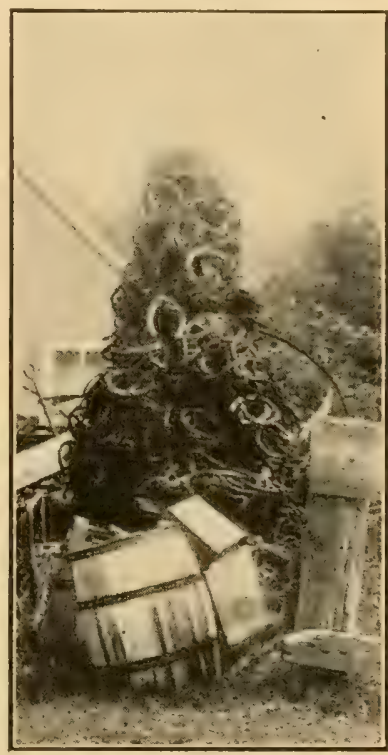

There was a Stack of Rusty HORSESHOES bent over. Next he snipped off the bent ends of the nails with big, iron nippers. Finally he ran the rough file around the outside of the hoof, leaving it neat and smooth.

Near the road, by a corner of the shop, was a tall stack of old, rusty horseshoes. The top of the pile 
was higher than your head. This was Old Tom's business sign.

Horace and Jim walked into the shop and looked around. It was half dark inside, for there were only two low windows, and these were covered with dust and cobwebs. At the middle of one side was a brick forge with a smoky chimney, and overhead a big bellows with a leather thong hanging down. When you pulled this it sent a gust of wind shooting up through the fire in the forge, making the coals turn red and little sparks fly up the chimney. Close by was the anvil, on top of a wooden block. On the walls were rows of new horseshoes, hung on nails.

When the boys came out again, Uncle David looked into one of the boxes in the wagon and brought out a paper package.

"Must be after dinner time," he said. "Here's something Aunt Lucy put in for us.'

The boys climbed up on the seat of the wagon, opened the package, and dived in. Uncle David walked around with a sandwich in one hand, an apple in the other, and a doughnut hooked over a finger. By the time they had finished their lunch, Old Tom had reset Dan's shoes.

Jim and Horace went across the road to get a drink at the well where Old Tom lived. There was a wooden rail, like a big box, around the opening of the well. When you looked over you could see the 
water, 'way down deep, with the sky reflected in it. A bucket was fastened on a chain that ran over a pulley above the well. Jim let it down. When it struck the water, it turned on its side and filled. He hauled it up, full of water, and each boy took a big drink:

By this time Dan was hitched up, and they were ready to start for ho m e. The y drove out, down the short steep hill, and into the road that leads to the four corners. There were many people out, on their way to town to do their shopping.

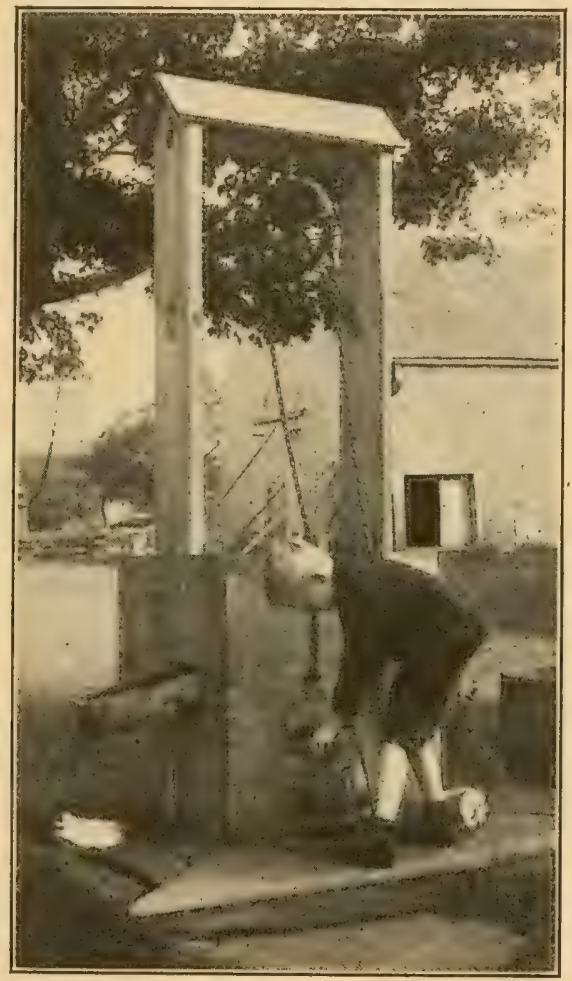

Jim and Horace got a Drink at the Well

Once they passed an ox team - great, strong fellows, with white faces and wide spreading horns. A man walked beside them, carrying a slender stick over one arm. The oxen moved very slowly. 


\section{IIO JIM AND PEGGY AT MEADOWBROOK}

They looked as if they could easily haul a heavy load.

Farther along Uncle David pointed out a big tank set on a wooden tower, on a knoll near a farmhouse.

"That's a pretty good water tank, isn't it ?" he

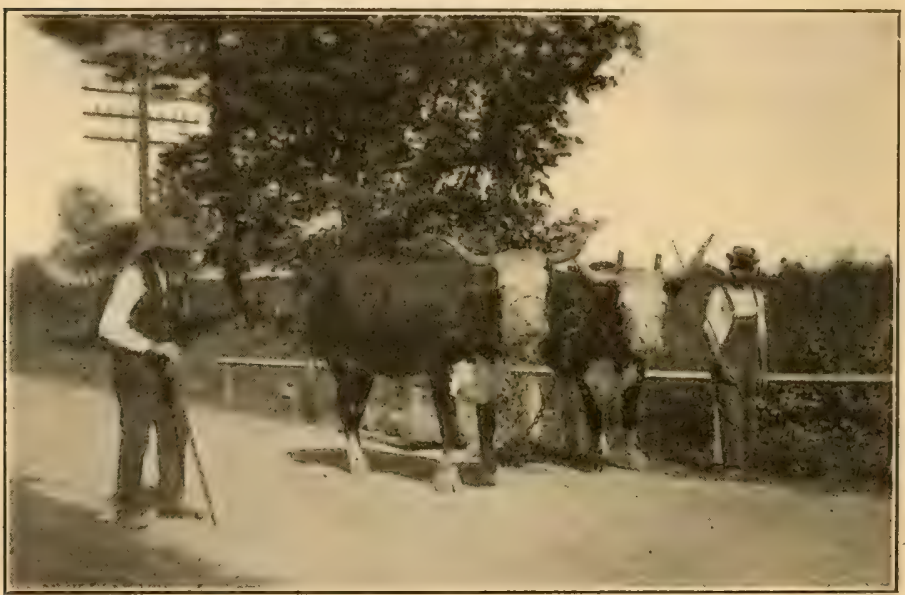

A Man Walked beside the Ox Team

said. "You see that's partly to protect the farm buildings from fire. There's a pipe from the tank to the house and the barn. If the tank is kept full it holds a lot of water, and it's so high that it gives enough pressure to throw a stream of water clear over the barn."

"Isn't there any fire department in the country?" asked Jim. 
"No, that's another thing that each farm has to look out for. Most farms haven't any fire protection to speak of - only buckets, or something of that kind, and they don't amount to much. Generally if a house or a barn catches on fire it burns down flat. But, you know, the houses are so far apart, it's usually a man's own fault if his place catches afire."

There was a windmill on a wooden tower, in a nield below the big tank.

"Guess that must be the windmill that pumps water to the tank," said Jim.

"No," said Uncle David, "there's a gasoline engine to do that. The windmill wouldn't supply enough. It doesn't pump fast; and

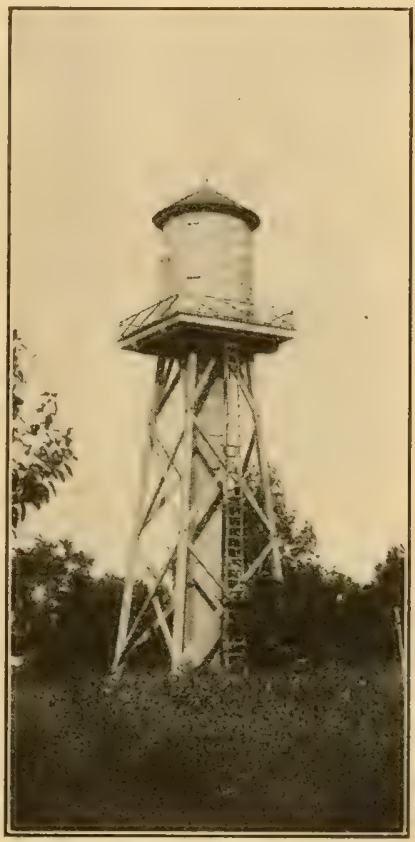

Uncle David Pointed out a BIG TANK besides there are often days in summer when the wind doesn't blow very much, or maybe not at all."

Old Dan traveled steadily on, around the turn at the four corners, along by the marshy place 


\section{JIM AND PEGGY AT MEADOWBROOK}

in the brook, past the schoolhouse at the fork, and then slowly up the hill. The afternoon was half over when they rattled across the bridge and turned into the lane at Meadowbrook Farm.

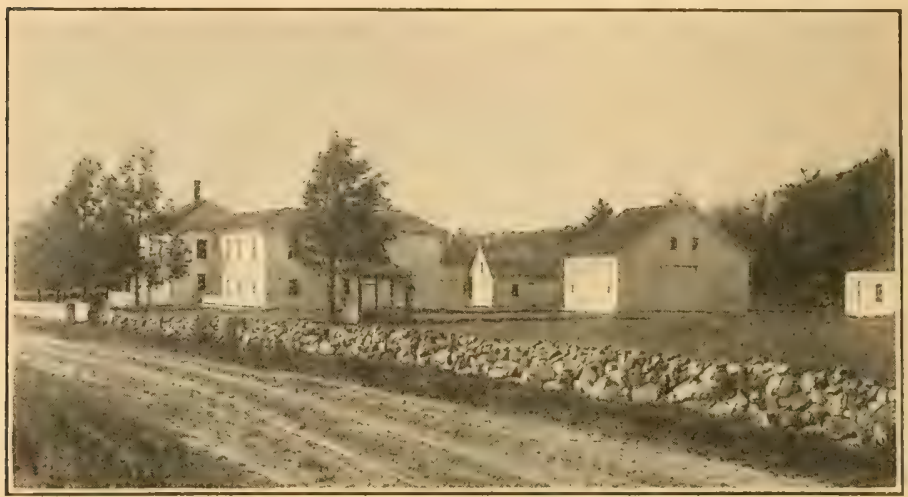

The Farm ihat Jim inought He would Like to Own 


\section{CHAPTER XVIII}

\section{A. VISIT TO THE REYNOLDS FARM}

While Uncle David and the boys were away on their drive to Freeport, Aunt Lucy and the girls had a trip of their own.

Everybody was up by daylight that morning. Breakfast came early, in order that Uncle David could get away promptly. Before long the dishes were done and the kitchen put in order. Jane and Peggy gathered the eggs and fed the chickens, scattering some of

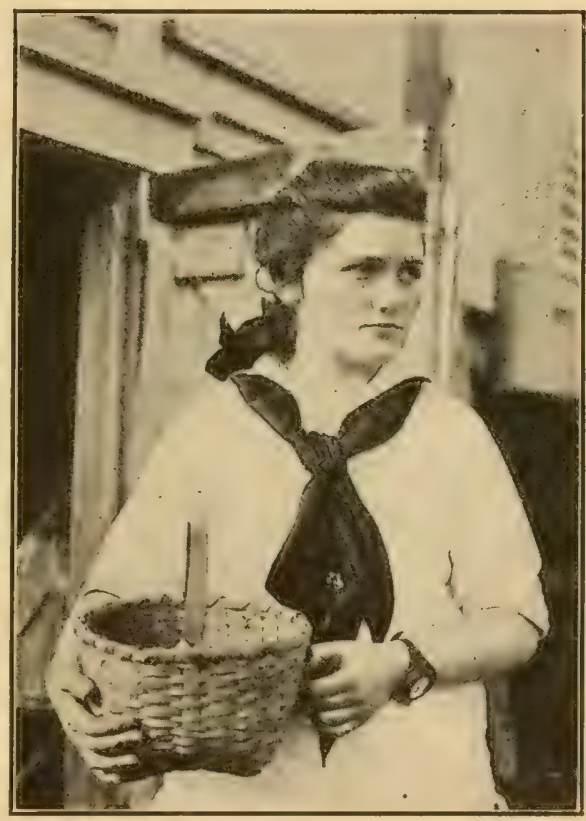

Jane Brought in the Eggs the grain under the trees in the orchard where the hens were scratching. Next they filled up the 


\section{II4 JIM AND PEGGY AT MEADOWBROOK}

ducks' bathtub for Brownie and Jerry. Peggy brought in a basket of chips from the woodpile. An hour later the beds had been made and the rest of the work about the house was finished.

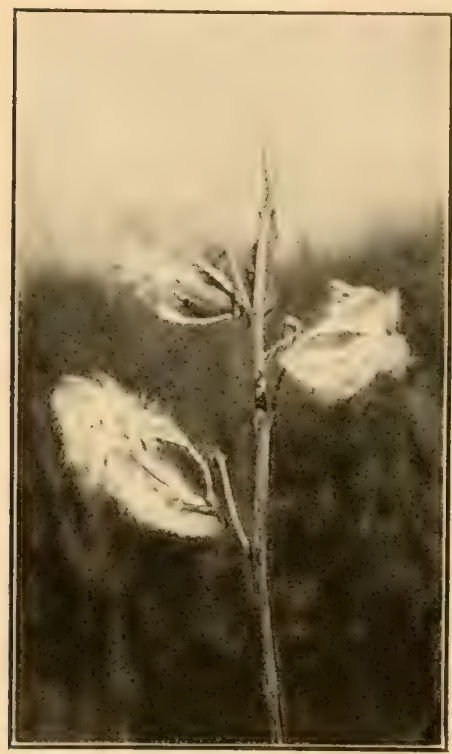

The Milkwend Pods had Broken OPEN

Aunt Lucy took off her apron.

"I'd like to see Mrs. Reynolds a few minutes about the church social," she said. "Don't you girls want to walk over with me?"

Spot had been left behind by the boys and Uncle David. So he went along, to call on his brother, Tag. Susan, the calf, called "Baa-a-a" after them as they went out the lane. Susan didn't have much use for Spot: he liked to bark at her, and that always made her jump.

In a fence corner Jane found a milkweed. The ripe pods had broken open, and the neat rows of brown seeds, each with its fluffy parachute of down, were ready for their flight. Jane ran up the road ahead of them.

"Let me send you a letter," she called to Peggy. "No fair moving from the letter box." 


\section{A VISIT TO THE REYNOLDS FARM II5}

She pulled out a mass of the seeds and tossed them into the air. The breeze carried them toward Peggy.

"Make a wish, quick," called Jane. "If you get a letter it will come true."

Peggy reached high for the nearest seeds, but

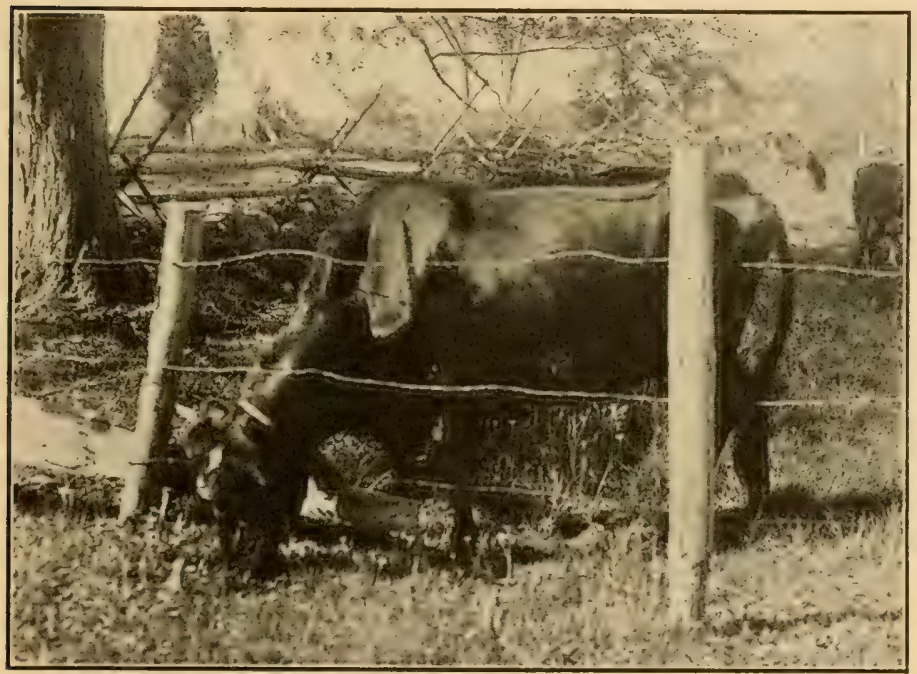

Andy's Cow was Reaching through the Fence

the wind carried them by, just beyond the tips of her fingers.

"Anyhow, I didn't have time to wish," she said.

There were handsome sumac bushes beside the road, the top of each bush gay with clusters of bright red seeds. From a low tree hung festoons of wild clematis vine, set all along with little fuzzy 


\section{II6 JIM AND PEGGY AT MEADOWBROOK}

tufts. Beneath the clematis was a plant of wild aster, with beautiful, violet-blue flowers. Jane started to pick them, but they looked so pretty where they were that she let them be.

They passed the house where Andy and Aunt Hannah lived. Neither was at home, but Andy's old

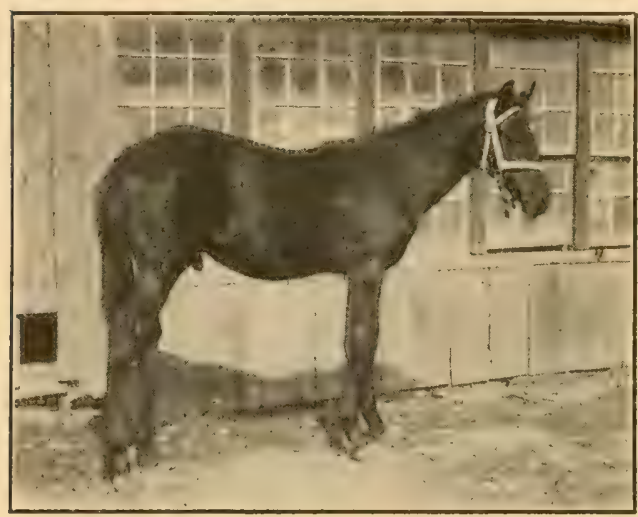

Henry Brought out his Colt

cow came over to the fence and looked a $\mathrm{t}$ the m. After they had walked by she stuck her head between the wires at the bottom of the fence, to get at the grass on the other side.

The last they saw of her she was still there, reaching farther and farther out through the wires.

They turned in at the Reynolds farm. Mrs. Reynolds saw them coming, and she and Polly came out on the porch to meet them. Jane and Peggy and Polly sat on the porch for a few minutes. Then Henry Reynolds and his small brother Sam took them out to the chicken yards and the barn.

Sam had a flock of chickens that he called his own. He had already been feeding them, but he 


\section{A VISIT TO THE REYNOLDS FARM II7}

made Henry get another measure of grain and hold it for him while he scattered handfuls of it among the hens.

Henry brought out his colt for the girls to see, a dark bay, except for a tiny white star in the middle of his forehead. Henry turned him loose in the feed yard, and he jumped and ran around like a boy just out of school.

Polly ran to one of the chicken yards, and came back with her pet drake, Moses, in her arms. He was a big, white fellow, with yellow

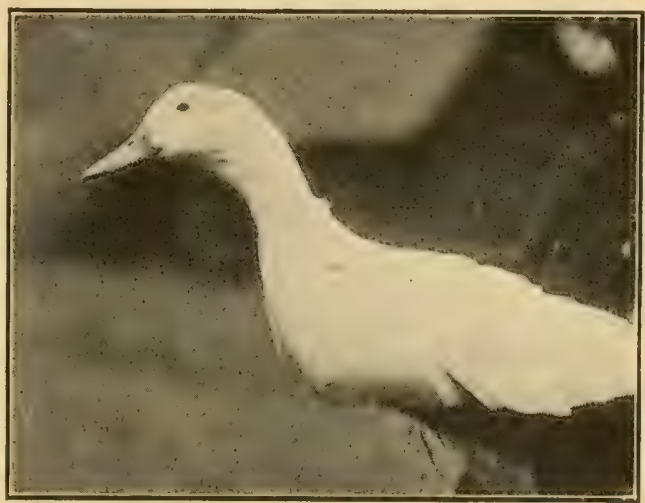

Polly Came back with Moses eyes, - a Pekin drake, Polly said. Henry brought a pan of grain. Polly sat down with Moses in her lap, and Jane held the pan while Moses gobbled the grain.

Then there were four or five shy, little calves to see; and a flock of noisy geese that stuck out their heads, hissing and honking; and a lot of busy, grunting and squealing pigs, big and little. When they returned to the house Jane and Peggy found 


\section{J JIM AND PEGGY AT MEADOWBROOK}

that they and Aunt Lucy were to stay for dinner.

Early in the afternoon Aunt Lucy said that it

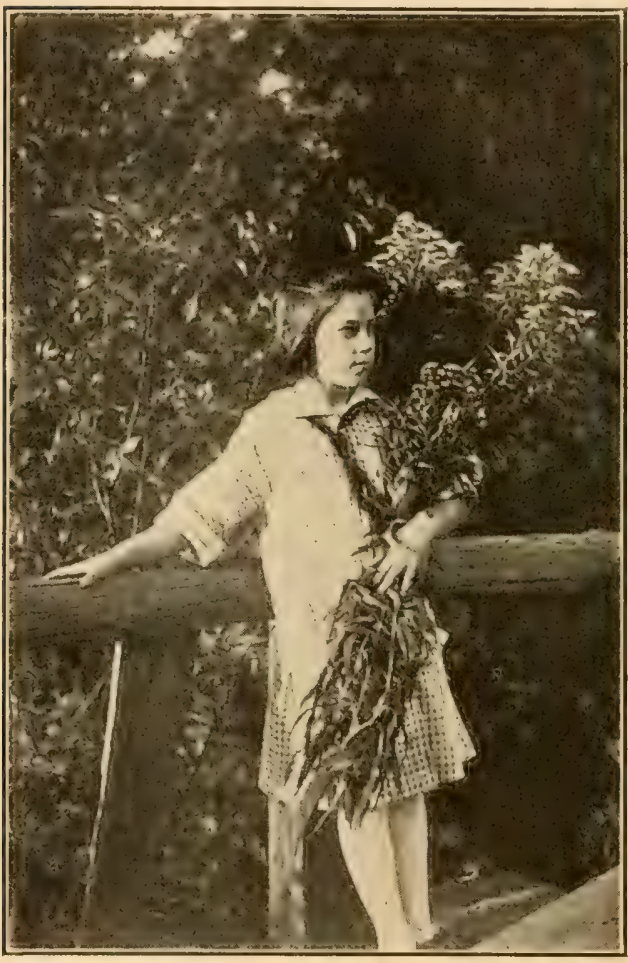

Peggy Gathered an Armful of Goldenrod

was time to go back home.

"This isn't getting my work done," she said. "David and the boys will be coming back soon, and there's supper to prepare."

Pollywalked b a ck with them as far as the lane to Meadowbrook Farm. Just beyond Andy Wiggin's place they stopped to look at a big clump of goldenrod, growing between the fence and the road. It was in full bloom. The top was a mass of rich, golden yellow.

$$
\text { "May I pick one?" asked Peggy. }
$$




\section{A VISIT TO THE REYNOLDS FARM II9}

"Why, yes, child," said Aunt Lucy, "all you want."

"Don't they belong to anybody?" Peggy asked.

"No, these are just wild flowers. There are so many of them everywhere that none of the people living on the farms would care if you take them."

So Peggy gathered an armful of the long stalks with their yellow plumes at the top, and carried them home with her.

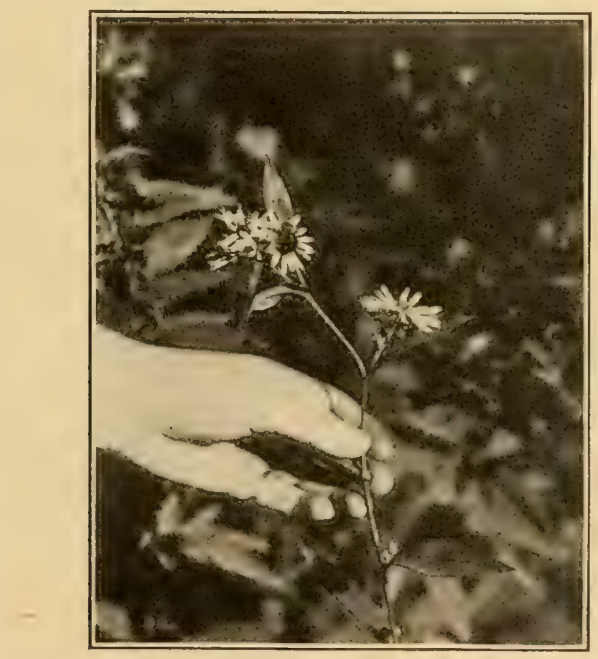

Wild Asters, with Violet-blue Flowers 


\section{CHAPTER XIX \\ SUNDAY MORNING}

IT seemed pretty threatening when Jim looked out of his window early next morning. For a moment the sun would shine; next a cloud would shut it out; then there would be a flash of sunshine

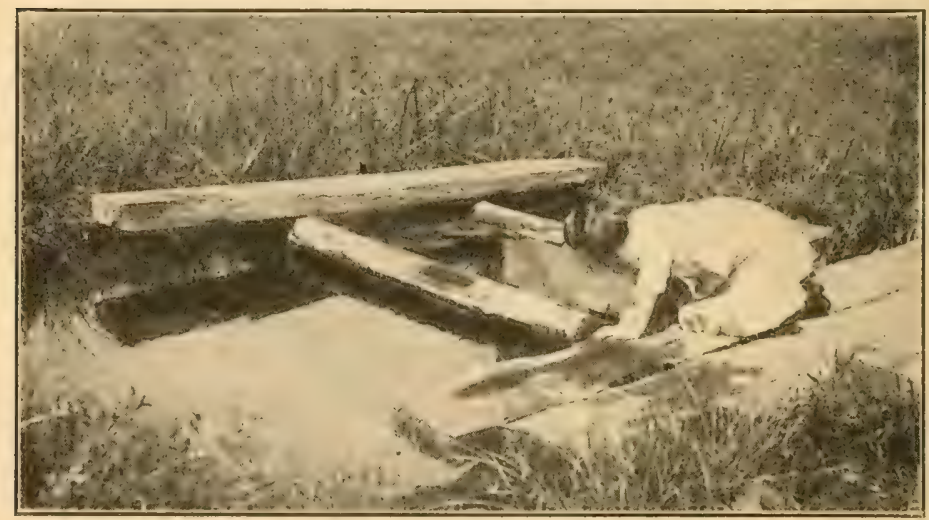

Peggy got a Drink at the Spring

again. Jim remembered that it was Sunday and wondered if they would drive to town to church, as Aunt Lucy had said they would the night before, and if Uncle David would take him and Horace for a tramp after dinner, as they'd planned. 
Peggy and Jim walked down to the spring before breakfast. It was always more fun to get a drink there than at the house. The water seemed better, and it was interesting to watch it come boiling up through the white sand in the bottom of the pool.

The spring was on the farther side of the brook, at the foot of a bank. There was a path to it from

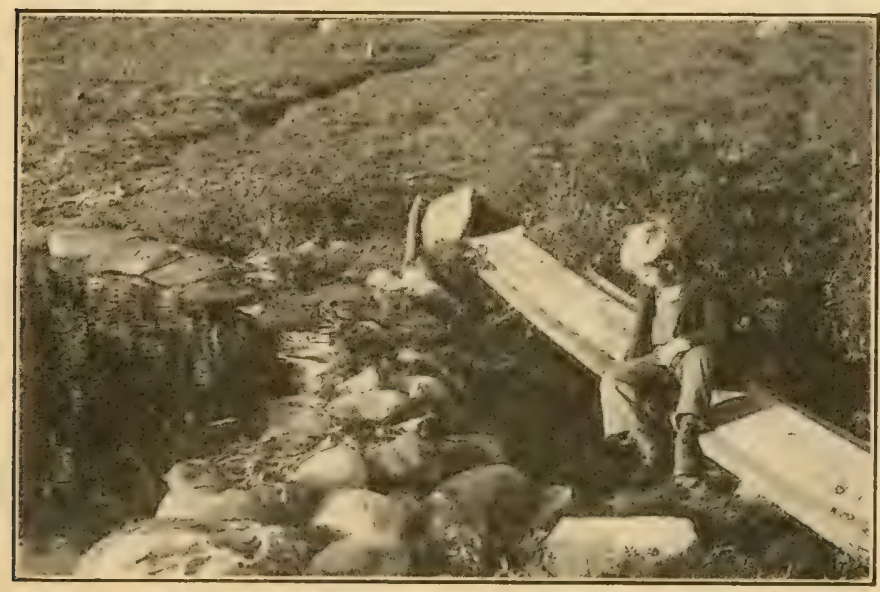

The Brook Widened oú above a Dam.

the house, with a plank for a bridge where the path crossed the brook. Just above the plank the brook widened out above a little dam, made partly of stone, partly of earth. Jim sat down on the plank, and watched the wate flowing down over the stones of the dam.

Soon Uncle David joined him.

"This brook's a pretty good worker, Jim," he 


\section{I22 JIM AND PEGGY AT MEADOWBROOK}

remarked. "Did you know that it pumps the water that we use at the house ?"

Jim had noticed a kind of box on the bank, a little below the dam. Down in the hole under the

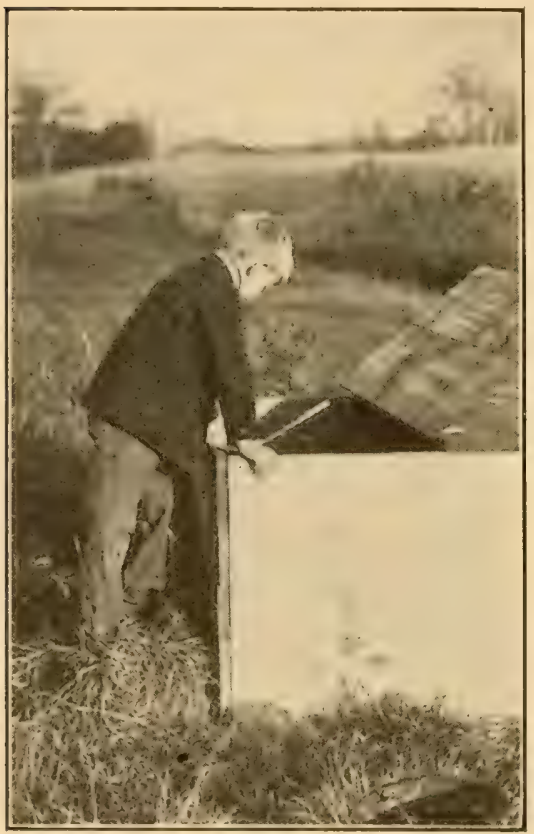

THERE WAS A BOX ON THE BANK box he had seen a small, round, iron thing that kept "chug, chugging" steadily away, all the time. Every time it chugged, a spurt of water came out at one side of it. Uncle David explained how it worked.

"There's a big pipe," he said, "that runs from above the dam down to the bottom of the hole below the box. The machine down there is what is called a ram. The water from the brook flows through it and makes it pump. But it doesn't pump the brook water. There's another pipe, a small one, that comes from the spring to the ram. That is the water that the ram pumps. It sends 
it up through a supply pipe to a tank in the attic of the house. It doesn't pump very fast; but it works all the time, night and day, and so it gives us all we need. In winter it works just the same as in summer."

There didn't seem * to be any doubt in Uncle David's mind about driving to town to church. After breakfast Andrew brought Milly out from herstall, hitched her to a ring at the door of the barn, and gave her coat a good cleaning. In one hand he held a sort

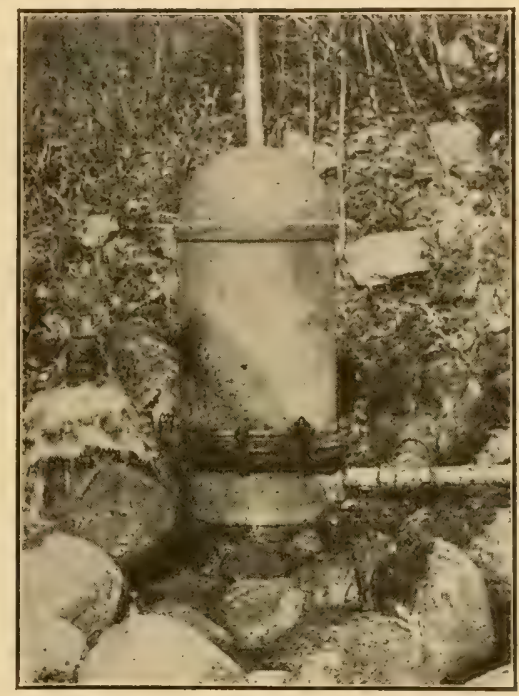

The Ram Pumped Water to the House of flat scraper, with thin iron ridges on the under side of it : - a currycomb, he called it. In the other hand he had a brush that looked like a big hairbrush without any handle. With the currycomb he scraped off any mud or dirt on Milly's coat; then he rubbed her hair with the brush. Every little while he knocked the currycomb edgewise against the door frame to get the dirt out of it. Sometimes Milly would switch her tail or 


\section{I24 JIM AND PEGGY AT MEADOWBROOK}

start to raise one of her hind legs, and then Andy would say "Steady now, steady."

After Andy had her sleek and clean, he picked Jim up and swung him on to Milly's back. She seemed pretty big

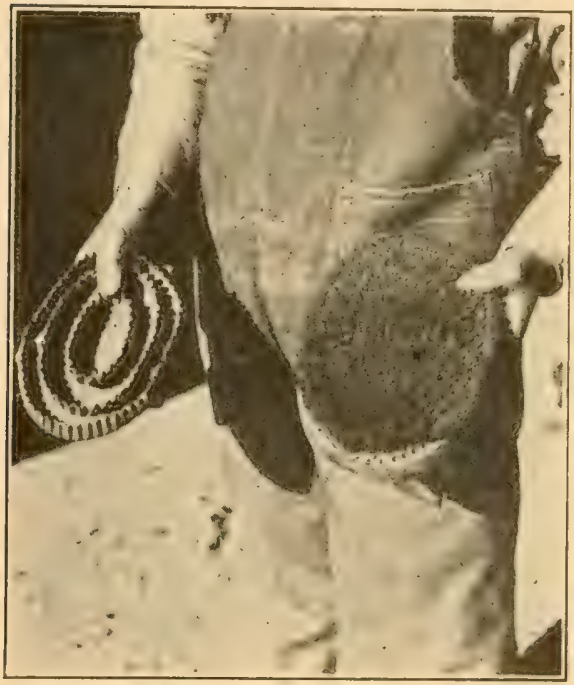

ANDY TOOK THF ('URRYCONB ANI) BRL'SH to Jim. Her back was broad, and his feet reached only part way down her sides. When Jim had looked at her from the ground she didn't appear very large, but when he was on herback it seemed different.

Aunt Lucy came out then and called Jim and the others into the house, to wash up and change their clothes.

By ten o'clock they were on their way to Milford. Milly jogged along, up over the hill, down by the schoolhouse, and past the place where the road crossed the brook at the marshy spot and the trees arched overhead.

When they arrived at the church they drove 
around to the rear to leave Milly and the surrey. There was a long, low building there, open all along one side. In this were a dozen carriages and buggies, lined up beside one another. They found a place for Milly, toward the farther end.

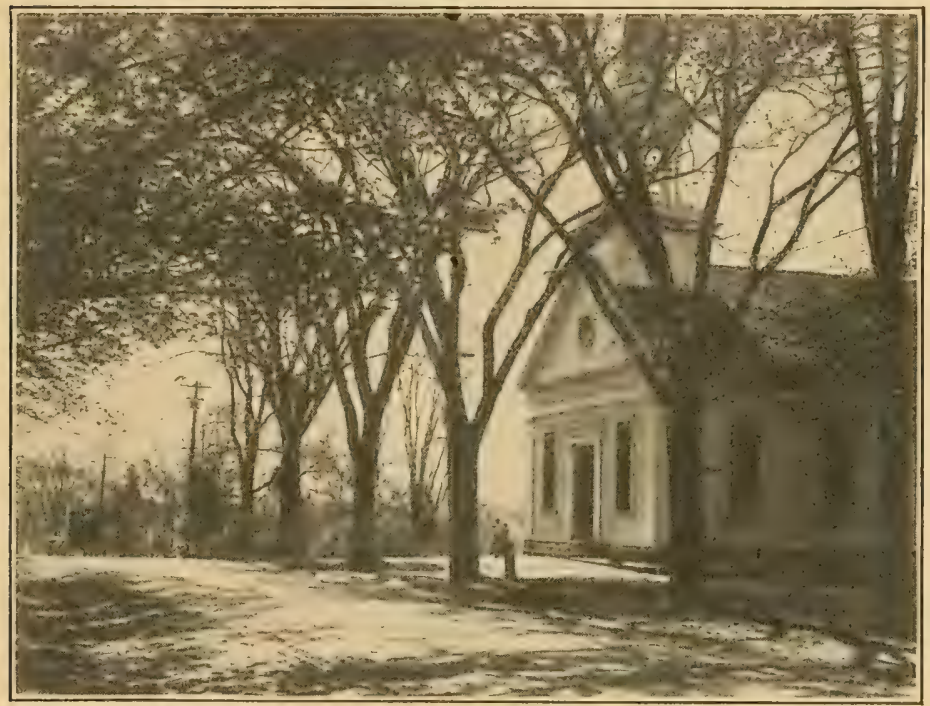

The Church at Milford

When church was over they drove back home again. It was after one when they reached Meadowbrook Farm. Hannah Wiggin was there, and had dinner ready for them. 


\section{CHAPTER XX}

\section{GOOD ROADS AND BACK ROADS}

HoRACE and Jim were out in the yard, throwing stones toward the brook to see who could hit the water. Uncle David had not yet left the dining table, but sat with his chair pushed back, talking with Aunt Lucy and the girls.

"Last day before school," remarked Horace. "D'you know that you and Peggy are going to start in to-morrow at our school?"

Jim nodded. Aunt Lucy had told him of the plans, and he had been wondering a good deal about the school, and how he would like it. He felt that he'd rather stay around the farm, though Peggy seemed anxious to go.

Uncle David came out with his hat on. He whistled for Spot. But Spot was behind the summer kitchen, eating his dinner, and didn't appear.

"Well, who wants to go for a walk?" he asked.

The three of them started off down the lane. In a few minutes Spot came tearing around a corner of the house, raced along to catch up, and 
nearly bumped into the boys' legs when he reached them.

Where the lane joined the highway Jim stopped and looked into the mail box fastened at the top of a post, beside the road.

"Won't be anything today," said Horace. "This is Sunday."

"Where does the mail come from?" asked Jim.

"It comes from Milford," answered. Horace. "Old Eben starts from there and goes to Moundville and back. He drives more'n twenty miles every day.

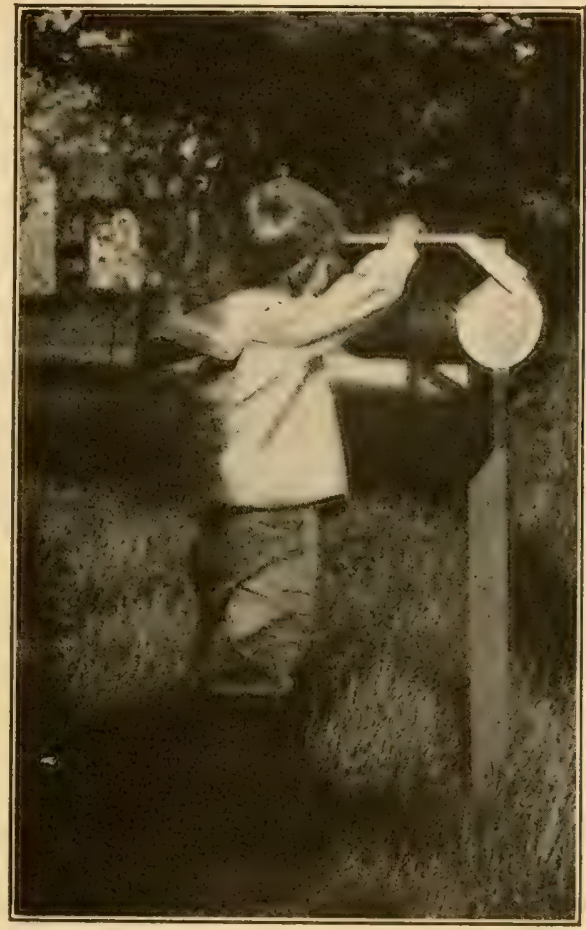

Jim Looked into the MaIl Box

Guess he's glad to have a rest on Sunday."

They turned up past the Reynolds farm, the opposite way from the direction toward Milford. The road was smooth and hard along there. 
Horace picked up a stick, held it out toward Spot, then threw it as far as he could, down the road ahead of them. Spot tore after it, stopping so quickly when he got to it that he slid along and sent the dirt flying.

"This is one of our main roads, Jim," said Uncle David. "It's been graveled and is kept up in

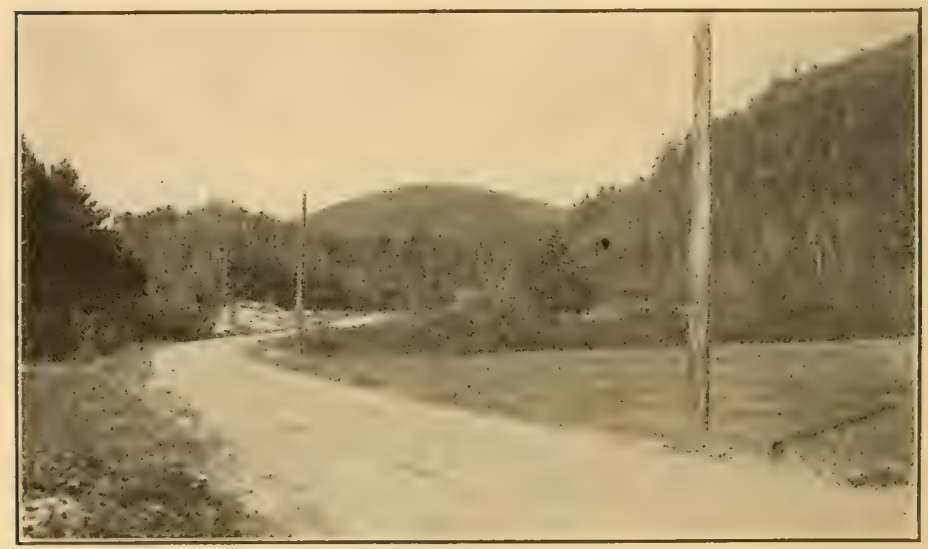

The Road was Smooth and Hard

pretty good order. It makes a good deal of difference to a farmer what kind of a road he lives on."

"What are the others like?" asked Jim.

"Well, they're a little of everything. Some sand, some mud, and some not much except a wheel-track. We'll come back over one like that." 
They came to a rough, square stone, set up in the ground beside the road. There was a letter chiselled in the stone on cach side, and a date, “i 899."

"What is it for, Horace?" asked Uncle David.

Horace shook his head.

"Where's your geography, son?" laughed his father. "That's the county line. This side is Lisbon County, where our farm is, and the other side is Union. You see, for one thing, each county doesits own work on the roads; so

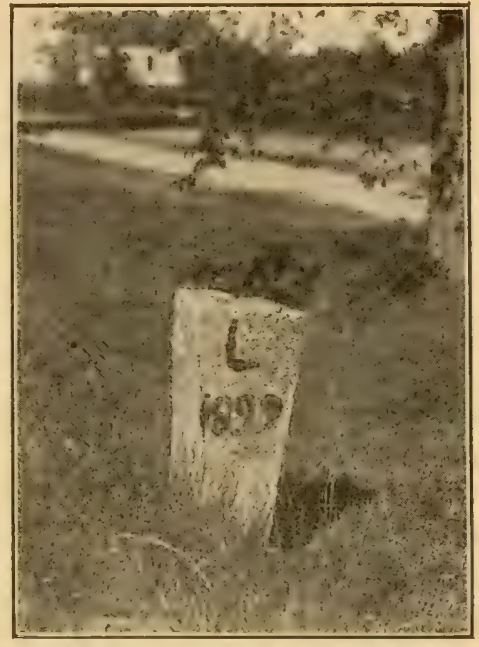

They Came to a Square Stone they have these stones to show where the line runs." "Don't think much of Union County roads," said Horace, shortly. They had reached a hill, and the middle of the road was washed out until it was covered with big and little rocks that turned under their feet as they walked up.

"These rocks would be pretty mean for horses, wouldn't they?" said Uncle David. "A team coming down here with a load might fall and get badly hurt." 


\section{I30 JIM AND PEGGY AT MEADOWBROOK}

"Can't they keep the road from washing out this way?" asked Horace.

"Yes, if they'd round it up, so that the water would run off at the sides. It means only a little work now and then. The trouble is that they never crown it up right in the first place.

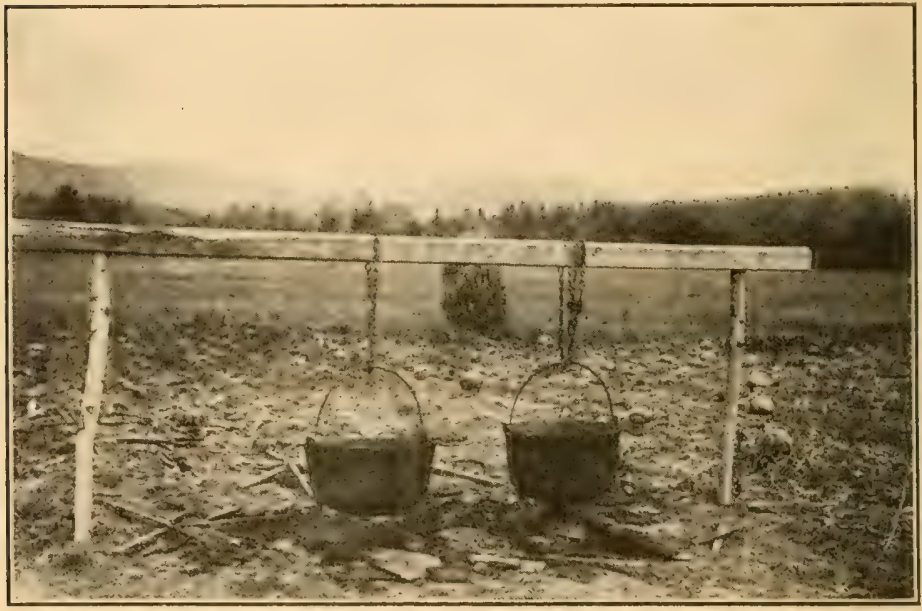

On a Framework Hung Two Iron Kettles

Then every rain makes a freshet down the middle of the road, and pretty soon the surface is all gone and there are only the rocks underneath left."

At a crossroads they left the highway they were on and turned to the right. At the corner stood an old house that looked as if it had been built a long time ago. In the yard there was a framework, and on this hung two big iron kettles, black 
as coal on the outside. Uncle David told Jim how kettles like these were sometimes used for making soap, out of wood ashes and the grease saved from cooking and butchering. Nowadays only a few farms make their own soap, because it is easy and

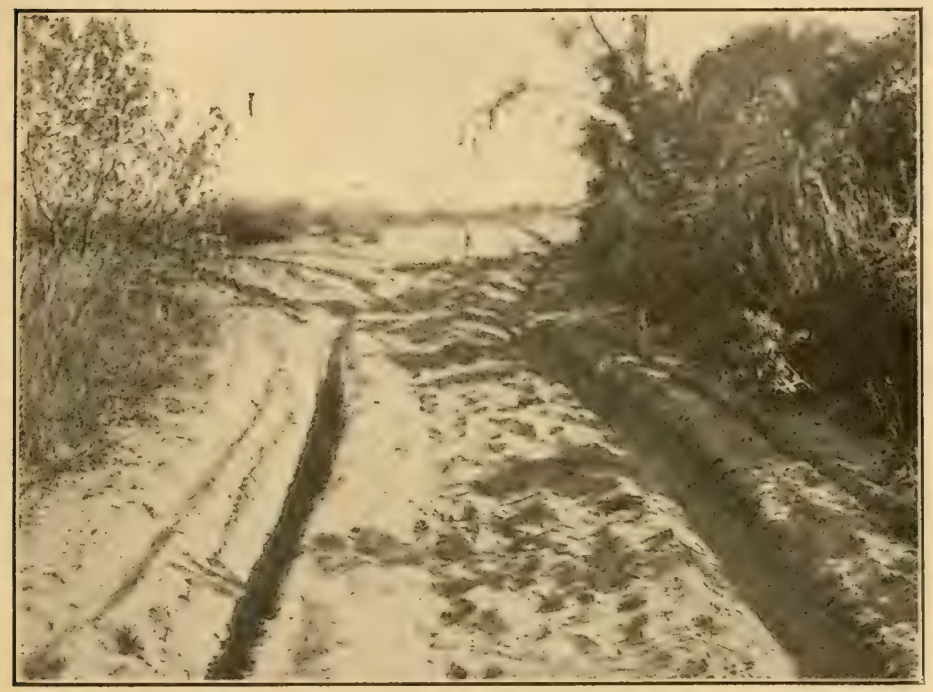

Soon the Road became Sandy

nearly as cheap to buy it ready made, and the soap you can buy is likely to be better than that you can make. These two kettles were not used any more for soap-making, but for boiling waste potatoes and other things to feed to pigs. "There ought to be brick-work built around them," Uncle David said, "to hold the heat." 


\section{I32 JIM AND PEGGY AT MEADOWBROOK}

The road they had turned into led from one main highway to another, - a "back-road," Uncle

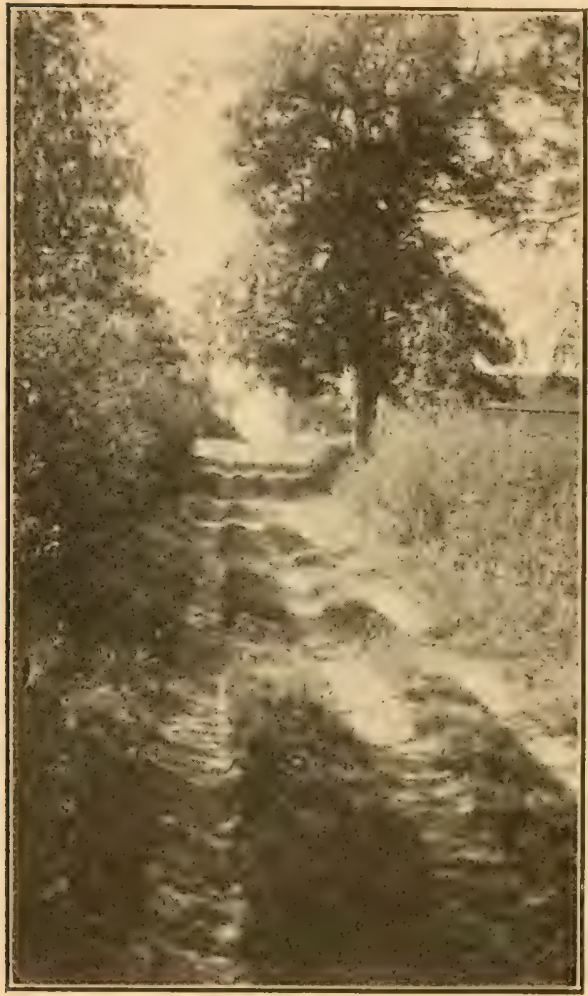

They Came Home by a Back-Road
David called it. Before long it dipped to a long, flat place and soon became s andy. The middle of the road was full of little hollows, wherehorses had stepped. There were deep wheeltracks. It was hard walking, very different from the highway that they had left. Their feet sank into the soft sand at every step. It began to get into their shoes.

Even Spot stopped racing around, and plodded along soberly at their heels. The farms on each side looked as if not much would grow on them, except coarse grass and weeds. 
"This is the kind of road that tuckers out a horse," said Uncle David. "You can't haul more than half a load, and your team gets worn out just trying to pull the wheels through the sand."

"Why don't they fix it up ?" asked Horace.

"It would be a hard job," said his father. "About all they can do is to haul in a lot of clay, and spread it on the sand, and that costs a good deal of money. There isn't enough travel to make it pay."

They came home by another back-road that was almost grown over with grass. It wasn't sandy there. The two wheel-tracks, and the place in the middle where the horses stepped, were hard, smooth dirt. They were like three paths, worn down so deep that the sod between stood up like a ridge. The road had never been graveled; but it was used so little that it wasn't worn out.

"This is the best road yet to walk on," said Jim.

"Maybe it is now," commented Horace, "but you ought to see it in the spring, after it's been raining for a while."

"Does it get muddy ?"

"I guess you'd think so - clear over the tops of your shoes." 


\section{CHAPTER XXI}

\section{SCHOOL}

Horace and Jim were ready for school in the morning before the girls had finished helping Aunt Lucy; sothey

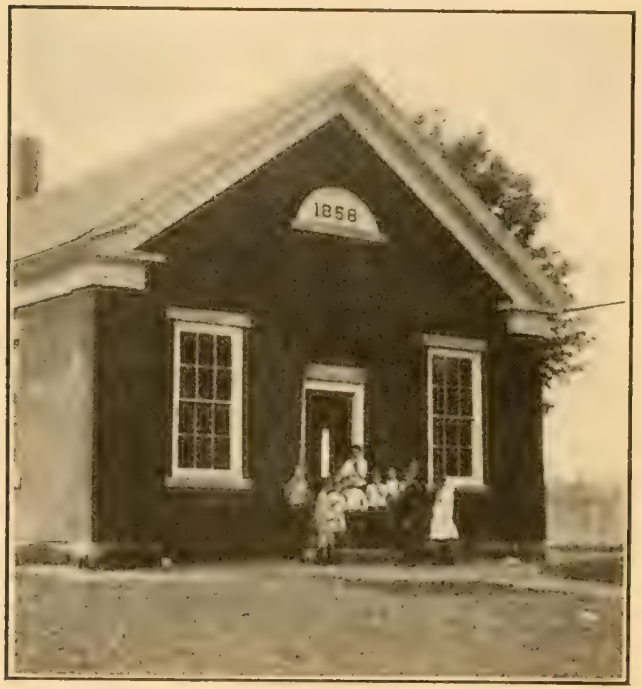

They AlL WENT INTO THE Schoolhouse started on ahead. They carried their lunch in a basket, for none of the children went hom e a t noon.

Spotwanted to go along. The boys sent him back twice. Then Spot ran out through a

field, up the hill through the woods, and came out on the road ahead of the boys. He stayed ahead of them after that, and they couldn't chase him back. 
Jim was wondering what the school would be like, and where Horace would be.

"What room are you in, Horace?" he asked.

"What do you mean?" asked Horace, puzzled.

"Why, I mean what grade."

"Oh, I'm in the seventh. - There's only one room at our school."

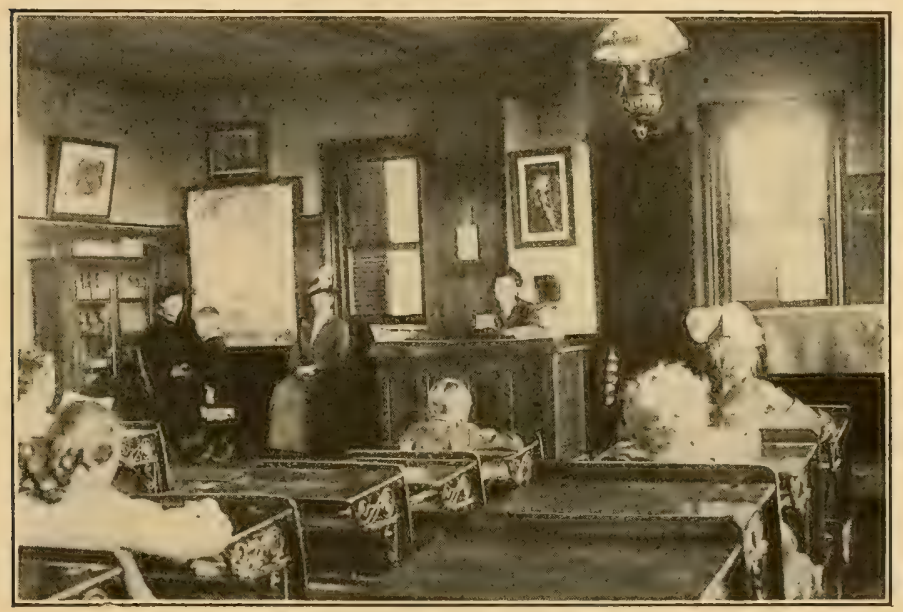

The Teacher Told them what Seats to take

Jim was surprised. So they'd all sit together. He'd never heard of a school like that.

When they reached the school yard half a dozen children were already on hand, running around, laughing and yelling. The game they were playing was cross-tag, just the same as Jim had often played at his school. In a moment he and Horace 


\section{I36 JIM AND PEGGY AT MEADOWBROOK}

were tearing around with the rest. Pretty soon Jane and Peggy came along and joined in. Four or five other children arrived. All of them carried lunches in baskets or boxes.

Then a woman came out to the door of the schoolhouse from somewhere within, and rang a bell that she held in her hand. They all straggled

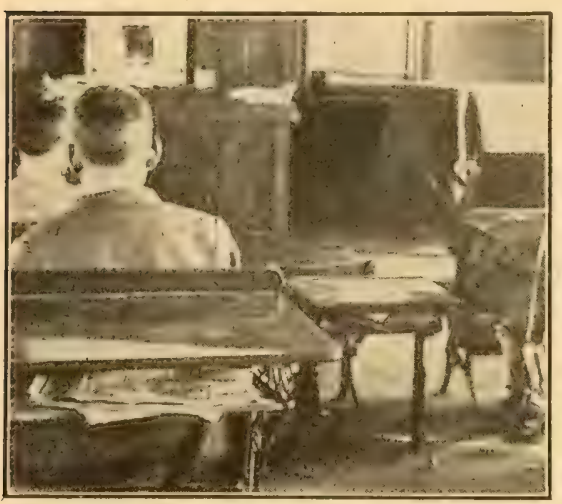

There were Two Tiny Desks up to the door and walked inside. As they went into the room the teacher called them by name, one by one, and told them what seat to take. Jim found himself not far from Peggy. Horace and Jane were over toward the farther side. Pretty soon books were given out and lessons started.

There were many things around to interest Jim and Peggy. It was hard to pay attention to work. Some of the desks were large, and some were small. There were two tiny ones, no bigger than children's play-desks. Overhead, hanging by chains from the ceiling, were four big, brass oil-lamps. At the back of the room was a round, black stove, with a 
wide top to it, like a collar sticking out flat. The stovepipe ran up toward the ceiling, and then turned and went across to the wall.

There were only a few children in each grade. In the eighth grade there were only two. While the children in one grade were reciting, the others were studying or doing other work at their desks, except for the smallest children, who couldn't be doing much unless some one was working with them. It was a task for the teacher to keep track of all of them at the same time.

At noon they all stood up and marched to the entry, where they had left their lunches. Then they ran out the door and raced across the yard to a place where there

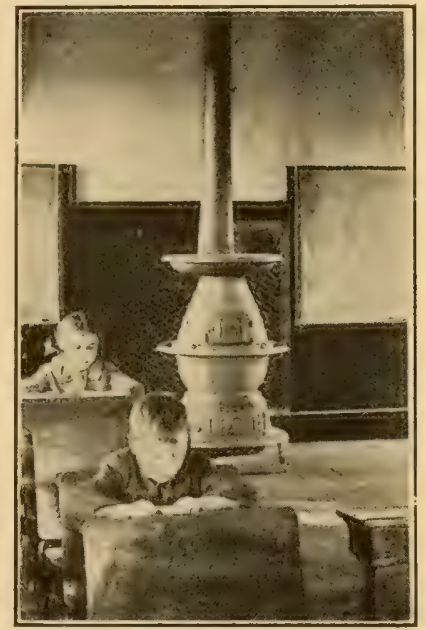

There was a Round Stove were boards piled up by a fence, beneath two big trees.

When they had eaten their lunches, one of the boys went down the road to some bushes and cut a forked stick. He picked out a fork that had three prongs to it. The main stem he cut off about six inches from the forked part. Then he 


\section{I38 JIM AND PEGGY AT MEADOWBROOK}

trimmed off the prongs so that each was the same length.

"Let's play ducky," he shouted, as he came back. " "Last one's it."

He set the forked stick on the ground, upside down on its three prongs. This was the "ducky."

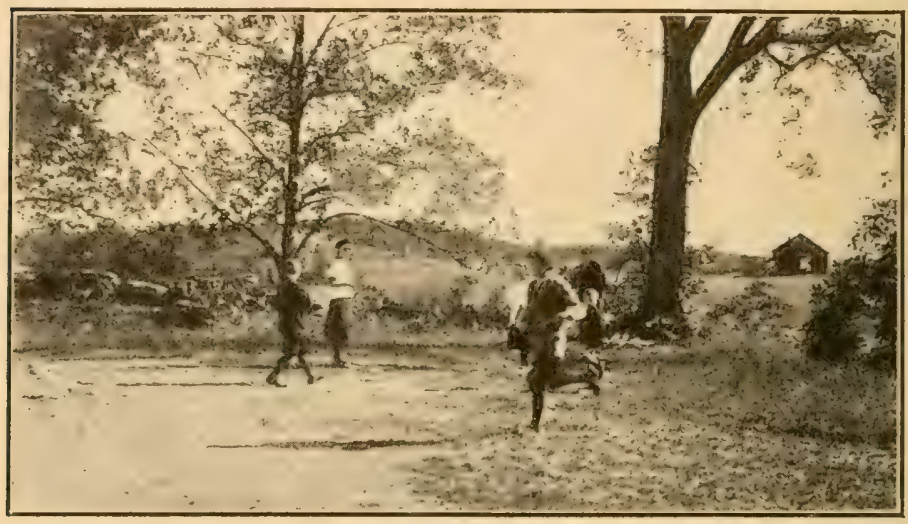

At Noon the Children Played "Ducky"

Each of the children scrambled to find a chip or a short piece of straight stick. Jim didn't know at first what to look for; so he was last and had to be "it."

The others showed him where to stand, near the forked stick. Next they lined up a little way off, and each one threw his stick and tried to knock the "ducky" over. After that each had to pick up his own stick and run back to the place where he'd thrown from, before Jim could tag him. But if 
the "ducky" was knocked over, Jim had to set it up first before he could chase anybody ; and everyone was safe and couldn't be tagged until he had picked up his own stick.

While they were eating dinner, clouds had been rolling up, and in the midst of the game a storm broke, sending them running into the schoolhouse.

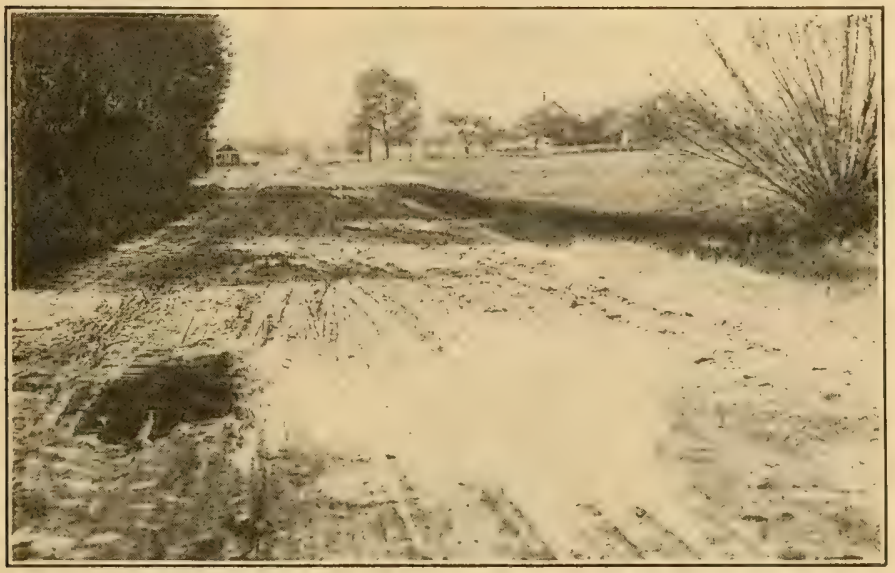

There were Big Puddles of Water in the Road

They played in there for a few minutes. After that school began again.

For half an hour the rain beat down. Then all at once it stopped, and in a few minutes the sun was shining as if nothing had happened.

When school was dismissed, the four children tramped home together. Spot was waiting outside and trailed along with them. It didn't rain 


\section{4 JIM AND PEGGY AT MEADOWWBOOK}

any more. But here and there in the road were big puddles of water, with mud between. The grass beside the road was dripping. Nobody had - thought of rain in the morning, when they started, so they hadn't worn heavy shoes. Their feet were wet and muddy when they arrived at the farm.

Uncle David told them that night that the county school board was thinking of changing the plan of the schools, another year. Instead of using the small buildings that were scattered here and there in the country, they'd have only two or three large buildings, with several teachers at each. Big busses would stop at the farms, pick up the children, and carry them to the new buildings. "Centralized schools," Uncle David called them. 


\section{CHAPTER XXII}

\section{WINTER SUPPLIES}

THE week slipped rapidly by, with every day filled up and busy.

Friday afternoon there was a teachers' meeting, so the children were dismissed at the roon hour.

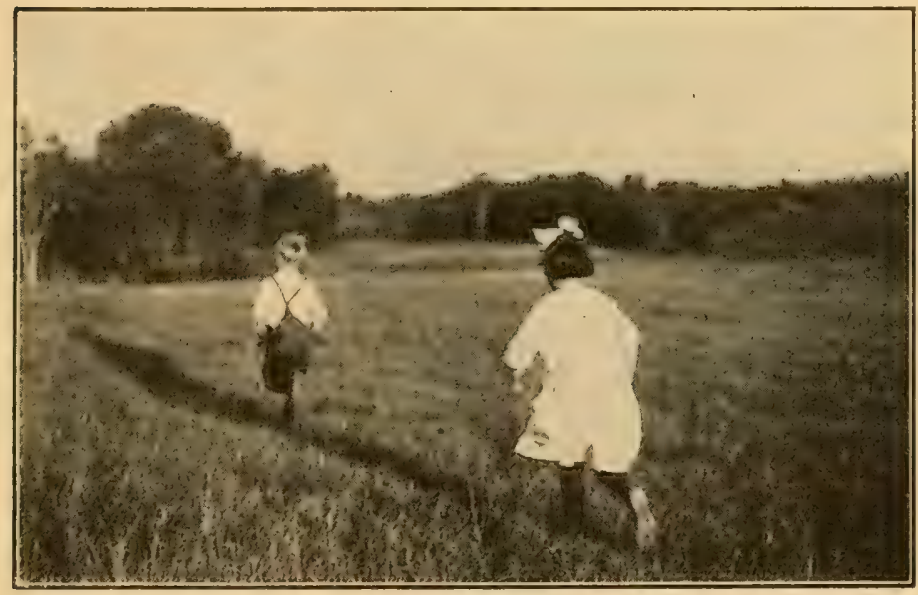

Jim and Peggy Sped across a Field

They trailed up the road toward Meadowbrook Farm for dinner. Spot was with them. He had been waiting outside the schoolhouse all morning. 


\section{JIM AND PEGGY AT MEADOWBROOK}

Jane and Horace were a little ahead of Peggy and Jim. At the bend in the road, near the top of the hill, Jim whispered to Peggy, and the two of them ducked under a fence, and sped off through a field, over a knoll at the top and down on the other side. Jim had

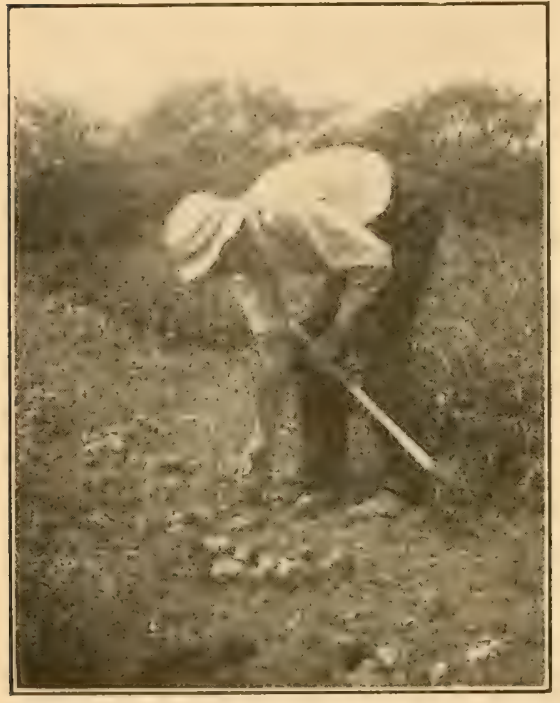

Andrew had been Digging Potatoes thought of a path that Horace had told him about. They hurried a long, down through a little wood, and came out by the spring, across the brook from the house. Horace and Jane had missed them, but thought they were coming somewhere back along the road. As they turned into the lane they saw Jim and Peggy hurrying across the meadow toward the house. Horace started to run, but the two children were already dashing up the slope and into the kitchen door.

Andrew and Uncle David had been working the day before digging and gathering potatoes. 
They used a fork that had a straight wooden handle and half a dozen slender prongs bent at right angles to the direction of the handle. This fork they would strike into the ground a few inches from the stem of a potato plant. Then they would jerk up roots and ground. With two or three more strokes and jerks they separated the potatoes from the earth, and rolled them out on top, to be picked up later and put into sacks.

To-day they were storing away the potatoes and other vegetables, for use during the winter.

Back of the

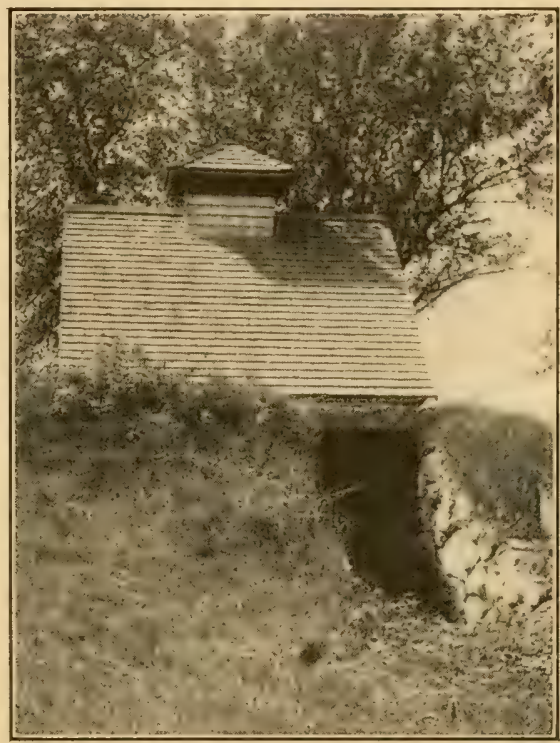

Back of the House was a Root Cellar

house, where the ground sloped away from the barn toward the garden, was a low building that Uncle David called the root cellar. It was really not a building, for the earth outside was sloped up to the top of the low walls, so that the roof began at the ground. At one side there was a 
I44 JIM AND PEGGY AT MEADOWBROOK

level passage into the bank of earth, with a door opening into the cellar. Inside were bins and barrels and shelves. It was cool in there, even when the day was warm; and in winter it never became quite cold enough to freeze.

In three of the bins Uncle David and Andy had put the potatoes they had dug and gathered. They had hauled them in sacks from the field, but they turned them out loose in the bins. Another bin, a shallow one, was filled with carrots - big fat red ones, the same kind that Horace had pulled up to feed to Nellie, the pig. Dry earth was thrown over these, covering them. A big box near by was full of onions.

The cabbages that were left in the garden came next. Part of them they pulled up, shaking the dirt from their roots. These were turned upside down on shelves, in the root cellar, just as they were, roots and all. The rest they cut off, leaving the roots in the ground. They broke off the outside leaves and put the white heads away in barrels. The turnips in the garden had already been dug and stored. There was a big bin of them, next to the potatoes.

Out in the yard, near the summer kitchen, was a heap of squashes. Part of them were oval in shape and dark green in color; part were flatter and a reddish brown. They carried all to a cool, dry room in the cellar under the house, piling 
them up next to a heap of pumpkins that had been stored there a few days before. In another room in the cellar, a dark one without any windows, Uncle David showed Jim and Peggy long rows of barrels full of apples. Some of these would be used on the farm during the winter. The greater

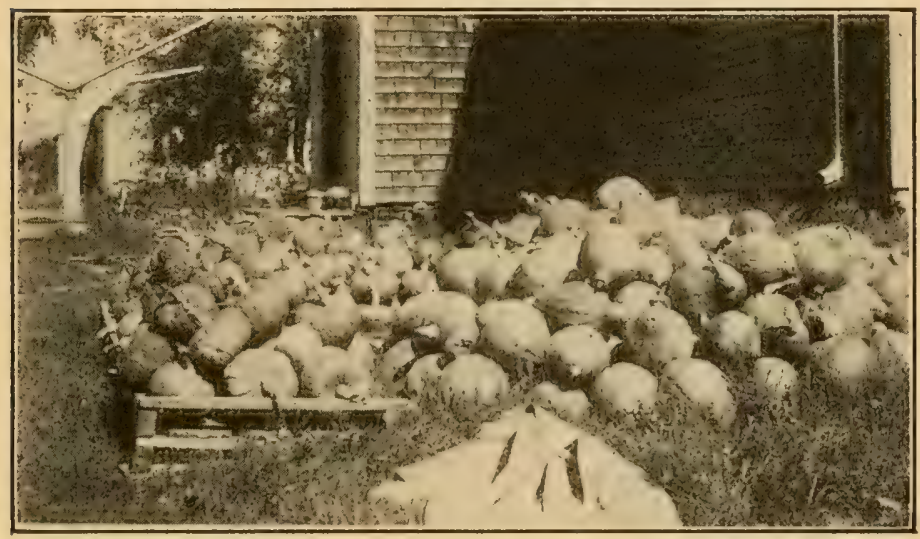

IN THE YaRd WAS A Heap of Squashes

part would be hauled to town, after a while, and sold.

A week or two earlier Andrew and Uncle David had pulled up the vines in the patch where the dried beans for winter were raised. The beans were still in their pods, fast to the vines. Plants, pods, and all had been stacked up clear of the ground, to dry out.

Andy drove out now and brought in a wagon load of the vines. They were dry and crackly, 


\section{I46 JIM AND PEGGY AT MEADOWBROOK}

and the pods were knobby where the shape of the beans inside showed through. Uncle David had sent Jane for a broom, and had swept a part of the barn floor clean. Andy heaped up the vines on the clean floor.

Then Uncle David took down his flail, a heavy, smooth, round stick, fastened by a short leather

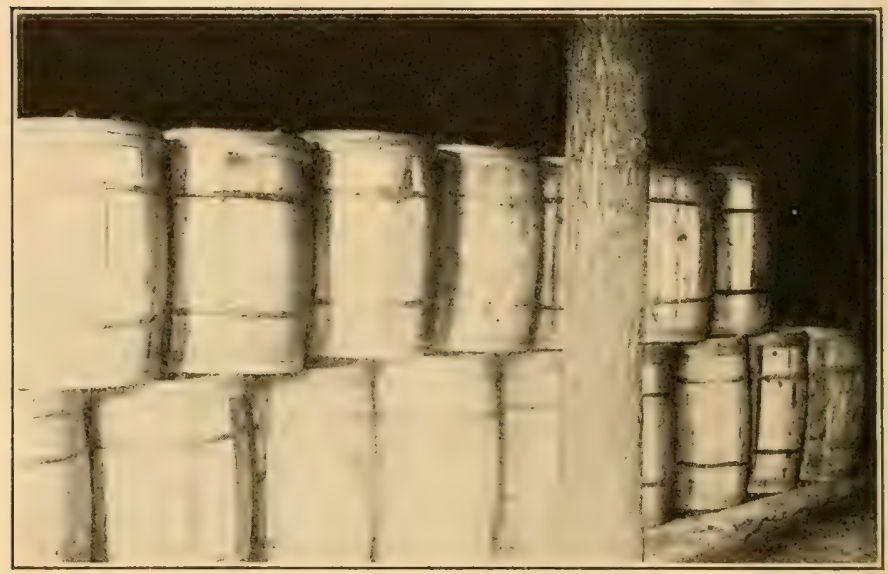

There were Rows of Barrels full of Apples

thong to the end of another more slender and longer stick that Uncle David held in his hands. Swinging this over his head he brought it down, whack, so that the shorter stick struck flat on the heap of vines. Up and down, up and down, he swung it, cracking the pods open, and sending the hard, round beans hopping everywhere.

After a while Andrew raked the vines away and 
gathered up the beans. He ran them next through a wooden machine that had a fan and a screen inside, to clean the beans of chaff and dirt. Then he carried them to the attic of the summer kitchen, and dumped them into a barrel.

Uncle David hung up his flail, and sat down on a box beside the children. $\mathrm{He}$ pulled out a handkerchief and mopped his face.

Peggy was

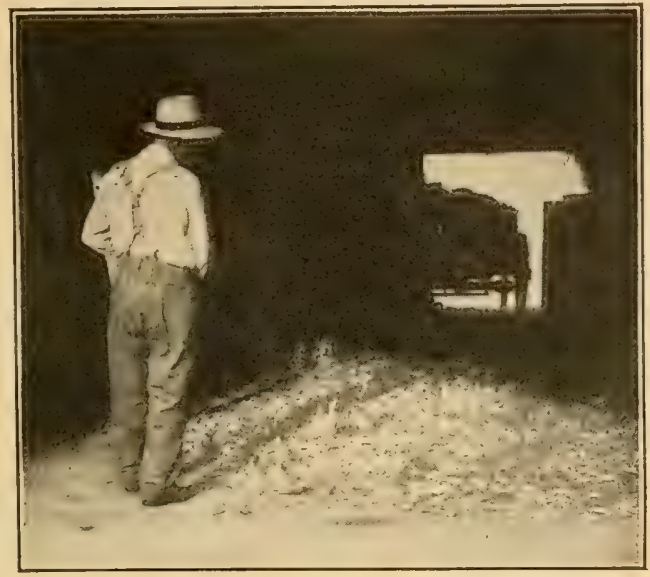

Uncle David Flailed out the Beans

thinking about the many things that she had seen stored away, in the root cellar, and the house cellar, and the attic.

"Uncle David," she said, "you don't have to buy, much at the stores, do you - things to eat, I mean."

"Well," said Uncle David, "there are a good many things, - sugar, and salt, and flour, and coffee, and other knick-knacks of one kind and another. But," he added, slowly, "we aim to have Meadowbrook Farm raise most of the things we eat." 


\section{CHAPTER XXIII}

\section{WOODCHUCKS AND CORN}

When Uncle David drove to Freeport, the Saturday of the following week, to deliver the eggs and butter, he took Peggy and Jane with him. Jane had declared that it was their turn, and Uncle David had acknowledged that it was, according to his way of looking at it. They expected to be back by noon, for they wouldn't need to go around by way of Milford; and

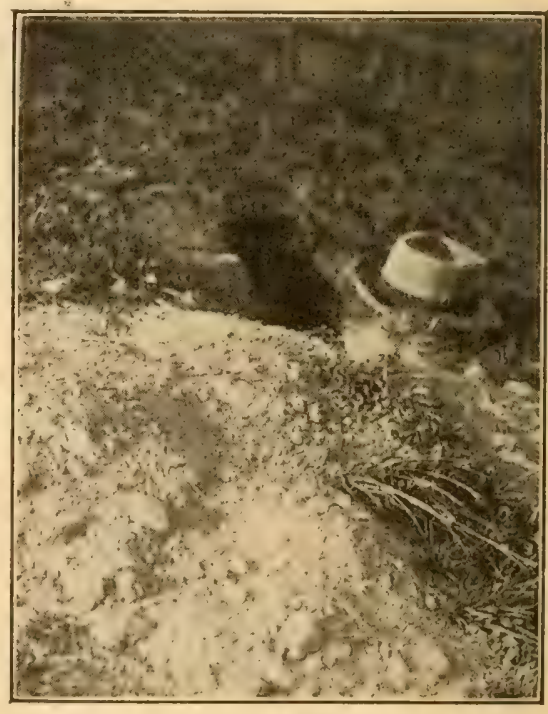
besides they were driving Milly instead of big Dan.

After the chores were done Jim and Horace 
called Spot and went out to the back fields to hunt up woodchuck holes. The "chucks" had been eating some of the corn in the shocks, Andy said. $\mathrm{He}$ thought that there must be half-a-dozen of them around. He had seen Spot tying himself into knots chasing one the other day. Spot didn't catch him; but the chuck made Spot hurry.

"Good thing he didn't," said Horace. "Chucks have pretty sharp teeth."

The boys hunted around half of the morning. They found four or five holes in one of the fields. Two of them were old ones. But the others looked as if they were in use. One had a big heap of fresh dirt in front of it, as if it had just been dug. There was another fresh one just under some fence rails. The boys were almost sure that they saw a chuck dodge down there.

"I'll tell you," said Horace. "There are some traps in the woodshed. We'll come out this afternoon and set them, and fix a surprise for Mr. Chuck."

They crossed to the field beyond the brook, and found Andy there, husking corn. Dan and Ben were hitched to a heavy farm wagon, standing by one of the shocks. Andy wore leather gloves, with round pieces of tin riveted to the palms and fingers. He ripped down the husks, tearing them loose from the ears first on one side and then on the other. Then he snapped off the yellow ear at its 


\section{I50 JIM AND PEGGY AT MEADOWBROOK}

base, and dropped it into a bushel basket. When the basket was full, he dumped it into the wagon. Each time he dumped in a basketful he made a mark with a bit of chalk on the side of the wagon bed.

Horace and Jim sat down at the edge of a shock,

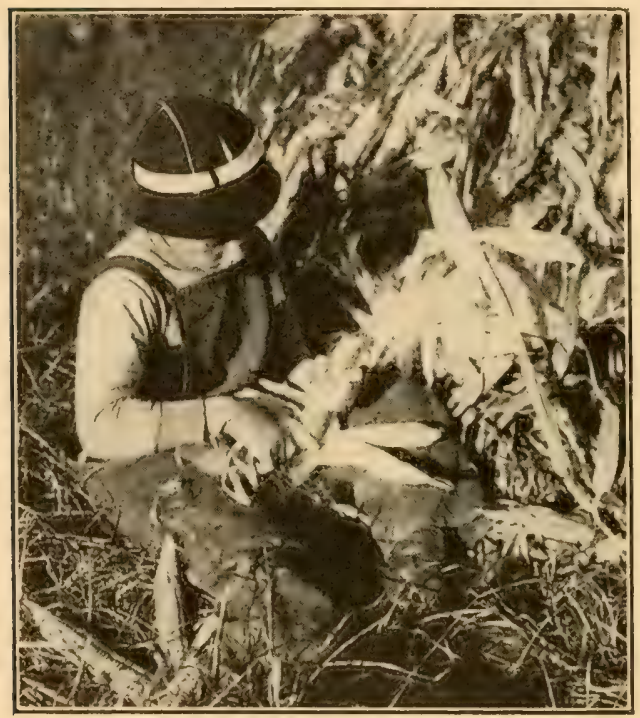

Jim Worked at Husking Corn and began husking. It looked easy to Jim, when he watched Andy do it. For a while he got along all right, though he couldn't work half as fast as Andy. The husks were tough, and it was hard to start them loose, unless you could rip through them. That was what Andy's tin-studded gloves were for. Pretty soon Jim's fingers began to ache. Horace didn't seem to mind. His hands were used to work of that kind.

When the wagon was full, Andy drove away with his load to the crib near the barn, and 
shoveled the ears out of the wagon, tossing them through a window of the crib. The walls of the crib were built with narrow spaces between the boards, so that air would blow through and help to keep the corn dry. The posts beneath the building had tin over the tops of them, sticking out all around. This was to keep rats from climbing up.

When Andy had gone, Horace and Jim walked over to the place near the fence where Jim had seen the squirrel the week before. They sat down

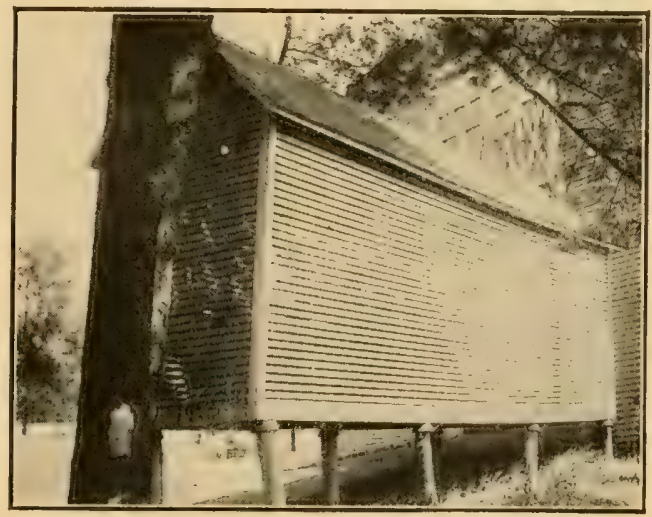

Andy took a load to the Corn Crib there to watch for him, Jim at one corn-shock and Horace at another. But Spot had been running around there, and the squirrel didn't show up.

Then they hunted for more woodchuck holes until they began to get hungry and concluded that it was time to go to the house for dinner.

Uncle David and the girls came back a few minutes later. As they reached the lane, Peggy jumped out and looked into the mail box. She 


\section{JIM AND PEGGY AT MEADOWBROOK}

found a letter addressed to Uncle David. They drove up to the house, and Andy unhitched Milly.

While the girls were telling their experiences to Aunt Lucy, Uncle David sat down in a chair by the kitchen window and read his letter. He looked

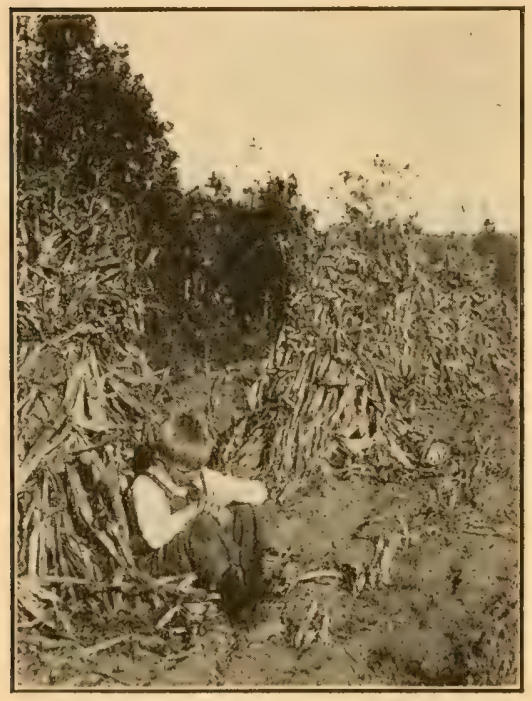

Jim Waited for the SQuirrel up, hesitated a moment, and then said, quietly, "Well, Peggygirl, are you ready to go back home?" "Why, Uncle David," she said, "what is the matter?"

"Nothing,Peggy. Your father is back from the hospital, and they are ready for you and Jim to come home.'

Peggy hardly knew what to say. She was so glad to have the word about her father - and yet she didn't like to think of leaving Meadowbrook Farm. Jim and Horace came in, then, and heard the news.

"When will they have to go?" asked Aunt Lucy. 


\section{WOODCHUCKS AND CORN}

"The letter says this afternoon," answered Uncle David. "They are to take the train at Milford at four o'clock, and their mother will meet them at the station, this evening."

Jane and Horace were deeply disappointed. They had thought that Jim and Peggy would be there for another week, at least.

"We were going to set traps this afternoon," said Horace.

Then he and Jane, both grew silent as they remembered what their father and mother had said to them at the beginning about having Peggy and Jim find out all about the country.

"I'll tell you," $\mathrm{s}$ a id Uncle

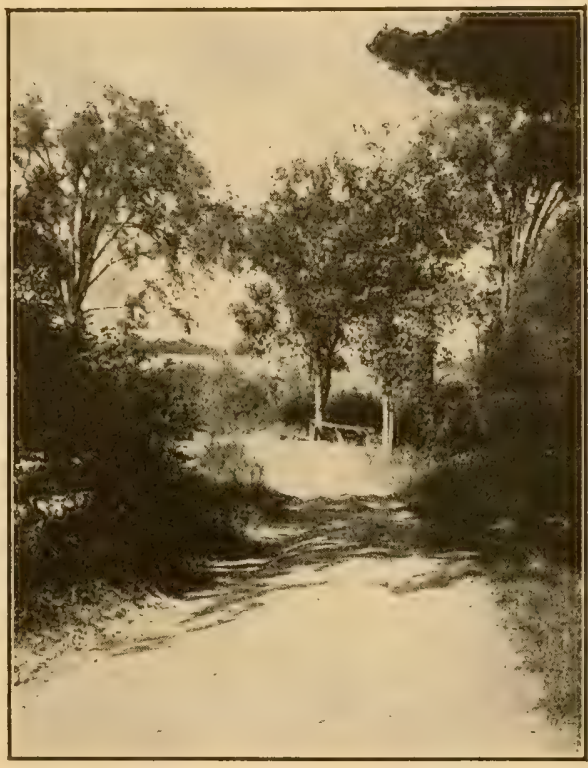

They Disappeared around the Bend in THE ROAD

David. "We'll let them go now if they'll promise to come back and see us again at Christmas time."

An hour later they were ready to start. Andy 
I54 JIM AND PEGGY AT MEADOWBROOK

had hitched old Dan to the surrey. With Uncle David on the front seat they drove down the lane, across the bridge, and disappeared around the bend at the foot of the big hill, on the road to Milford. 


\section{CHAPTER XXIV}

\section{THE ROAD IN WINTER}

For the next two months Peggy sent a letter to Jane every week or two, and Jane sent one to

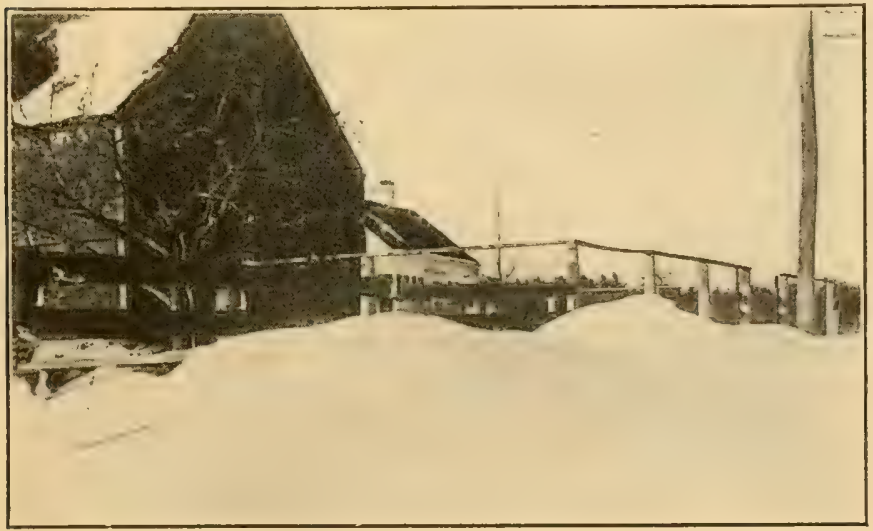

The Snow was Drifted halfway up the Fences

Peggy. Jim wrote to Horace only twice. The rest of the time he sent his messages in Peggy's letters.

About the first of December a letter arrived from Peggy saying that she and Jim were coming for a visit the day after Christmas. They couldn't 


\section{I56 JIM AND PEGGY AT MEADOWBROOK}

stay long: only four or five days, or perhaps until the day before New Year. Their father was better, but he wasn't quite well yet.

Christmas day came, and brought with it the first good snow of the season at Meadowbrook Farm. Andy got down the cutter that had been put away in the loft of the tool shed for nearly a year. Then he took the wheels off the light farm wagon, and put on a set of runners.

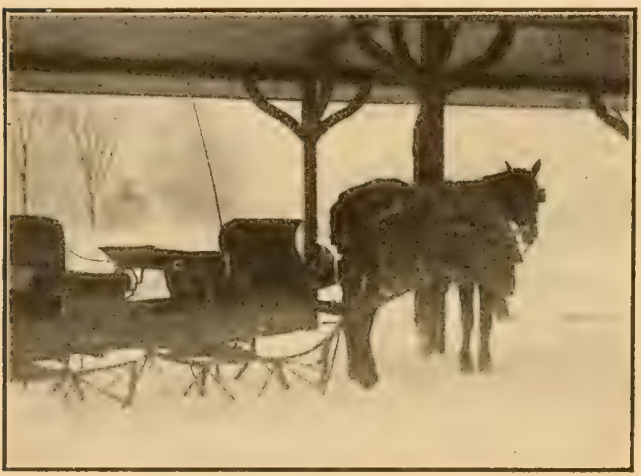

They pUt a Blanket on Dan

"It's going to be a good storm," hè said. "We wo n't go wheeling for a few days." In the afternoon Uncle David took the cutter and drove to the Sturtevant farm, on the road to Freeport, to see about another cow that he was planning to buy. He came back in the evening.

"There are some pretty deep drifts," he announced. "It's heaped up halfway to the tops of the fences, where the wind gets a sweep at it."

"Do you suppose it's going to be stormy tomorrow?" asked Jane. 
"No, it's turning colder. Looks as if it will be clear.”

Jim and Peggy were coming on the evening train. After dinner Uncle David looked at Jane out of the corner of his eyes, and asked Horace if he didn't want to go along to meet them.

"W e 11 ,

how about me?', de$\mathrm{m}$ a $\mathrm{n} \mathrm{d}$ e d Jane.

“ 'W h y, sure enough," said Uncle David, as if he hadn't thought of it before, "we'll have to m a ke room for you, too."

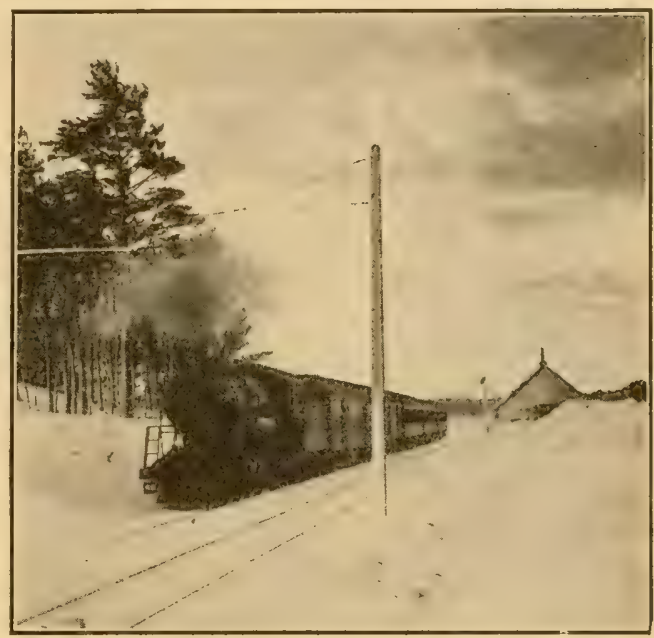

The Tran came Rumbing down the Track

Andy hitched up Dan to the light wagon and fastened in two seats. In the back of the bed he put a heavy blanket, to throw over Dan, if they had to wait long at Milford.

An hour and a half later the children and Uncle David stood at the end of the platform at the Milford station, and watched the train come rumbling 


\section{I58 JIM AND PEGGY AT MEADOWBROOK}

and grinding down the track. Before the cars had stopped they saw Jim and Peggy through one of the windows, making their way to the door.

Uncle David took Horace with him on the front seat, and put Jane, Peggy and Jim on the other. He tucked in big, woolly robes around them, with extra ones under their feet. Then old Dan started up, his bells going " jongle-ongle," and they drove out through the village street.

They passed the church. Its roof was covered with a thick white comforter of snow. The trees in front of it were plastered white all up and down one side of their trunks. A man was driving a pair of horses along the sidewalk, drawing behind them a V-shaped wooden plow. It dragged along, shoving the snow out to each side, leaving a smooth path behind it. There were handles on the rear of the plow, but the man rode standing up on the front part of it, balancing himself easily, sometimes tipping back a little, sometimes leaning forward.

They went down the short hill at a trot, old Dan sending a ball of snow flying from his feet against the front end of the sleigh. A cutter passed them, with a top on it like a buggy. Some one inside of it called out "Hello there, Jim."

"That's Henry Reynolds," said Horace.

They turned into the long level road, where the fields stretch away to right and left. The sun was 
almost down, making the clouds in the west look like dark masses of fleece, with silvery edges.

Soon it began to get dark. They passed a corner, and saw a dog with long ears come slowly

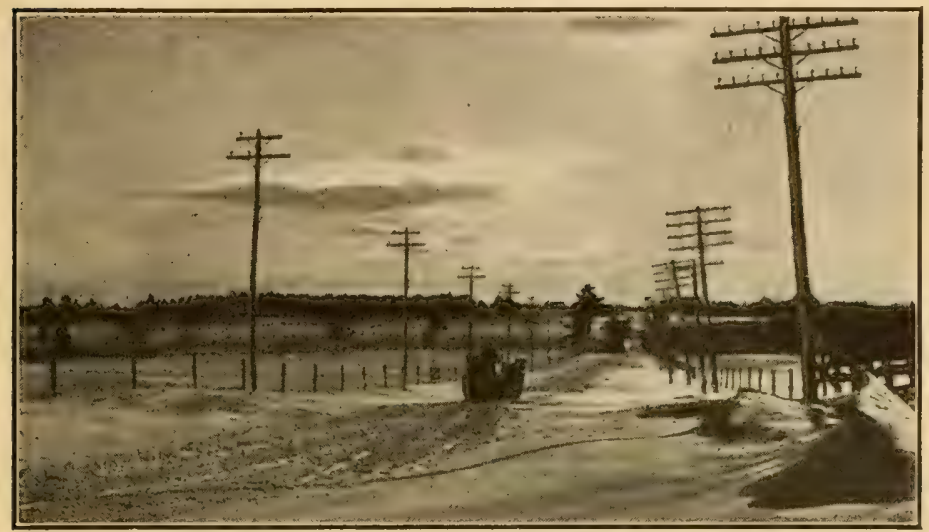

The Sun was almost Down

out of his box to watch them go by. Next there was a schoolhouse at a fork in the road. Dan plodded slowly up a hill. The wind came over the top and nipped at their faces. They wound down the farther side.

Almost before they knew it, they turned into the lane at Meadowbrook Farm. 


\section{CHAPTER XXV}

\section{A WINTER MORNING}

The farm looked strange to Jim and Peggy when they went outside next morning.

Everything was blanketed in snow. The woodpile was covered with it. You could see the shape of the top pieces of wood through the blanket. In the garden there were just a few old, broken cornstalks sticking up through.

Andy had been out with a shovel and a broom, and brushed the blanket aside in front of the kitchen door. He had swept a path from there around to the summer kitchen and the woodshed, out to the barn, across to the tool-shed, and over to the chicken house.

Outside of the path there were tracks here and there in the white blanket. Jim and Peggy could see where Dan had gone by pulling the sleigh after him, where Spot had been racing around, and the trails that the turkeys had made. The turkeys were nowhere in sight now. But in a moment the children spied Brownie and Jerry, on the steps of the summer kitchen, where there wasn't 


\section{A WINTER MORNING}

any snow. Peggy ran back into the kitchen and found some crusts of bread for them.

When the children went into the barn everything looked familiar again. There was the wall of hay, with the ladder running up toward the roof, though the wall wasn't as high or as long as it had been. Back where the stalls were, Dan and Ben and Milly stuck their noses out. Peter came sauntering along from the tool-room, where he was still busy catching mice.

In the wing of the barn, where the cows were kept, Belinda and the rest were lined up, with their heads through the square, wood frames.

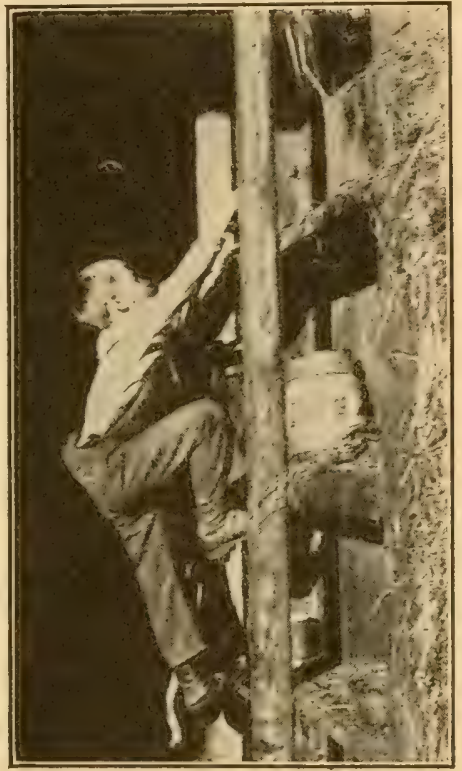

IN THE Barn Was the WaLl OF Hay and the LADDER There was no green pasture outside, now, for them to graze on. They spent most of the time in the barn, except when Andy let them out into the feed yard, to exercise.

Horace and Jane came out to the barn, and joined them. Andy took Ben out of his stall, put the harness on him, and hitched him to the sled. 


\section{I62 JIM AND PEGGY AT MEADOWBROOK}

He was going to the Sturtevant place to bring back the cow that Uncle David had bought.

Jane and Peggy walked over to the chicken house, to gather the eggs and say good morning to Hiram, the white rooster. Jane had a little round basket with her.

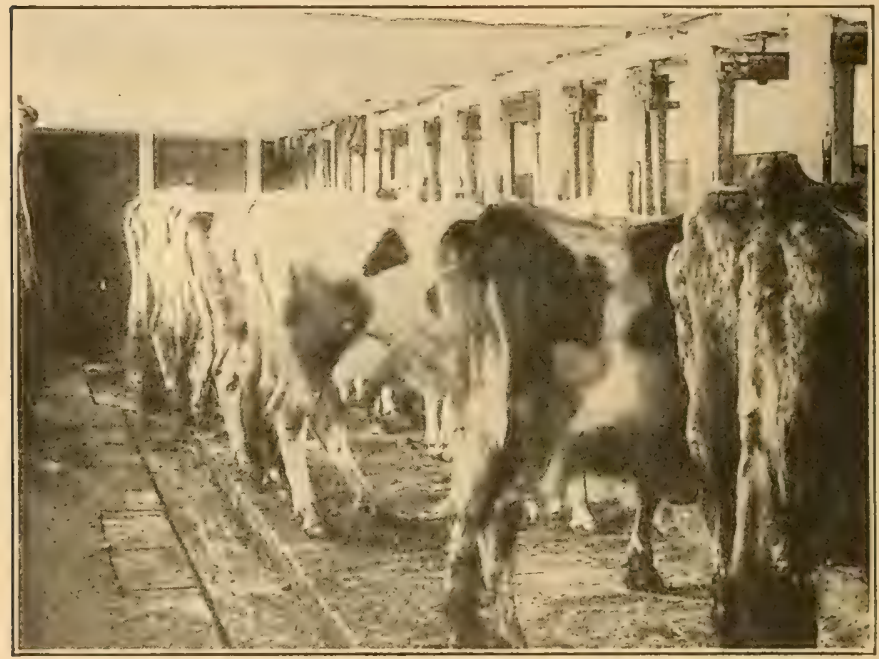

The Cows were Lined up in the Wing of the Barn

"You're not going to get the eggs in that little basket, are you?" asked Peggy.

Jane laughed.

"Hens don't lay much this time of year," she said. "I think they must get tired in winter. Half of ours aren't laying at all, and the rest don't seem very busy." 
"Maybe that's why Mamma said that eggs cost so much at the grocery last week," remarked Peggy.

Jim and Horace took Spot with them and went down to the brook. Jim looked into the top of the box over the ram. It was still chugging away.

Just beyond the bridge the boys found tracks in the snow, leading along the brook. There were two round tracks, and, just ahead of them, two longer ones; next a space of two or three feet; and then another set of round tracks and long ones. "Look where a rabbit's been hopping," said Horace. "He wasn't scared, either. See, he made only short jumps."

"Why are the tracks shaped like that?" inquired Jim.

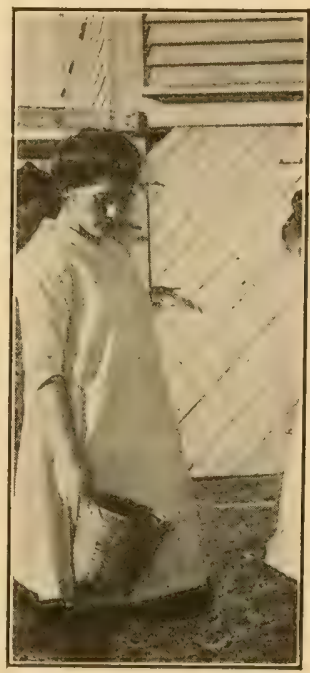

JANE HAD A LiTTLE Basket

\section{"The little round tracks are} his front feet, and the long ones are his hind feet. He always sets his hind feet down ahead of his front ones when he hops.'

"Did you get any of the woodchucks?" asked Jim. "You know - the ones we were going to set traps for, the day I went back home."

Horace shook his head. 


\section{I64 JIM AND PEGGY AT MEADOWBROOK}

"I think they moved away. Or else Spot scared them. I got a skunk, though," he added. "Caught him at a hole under the chicken house fence."

They walked on down the brook. Here and there the snow was halfway to their knees, where

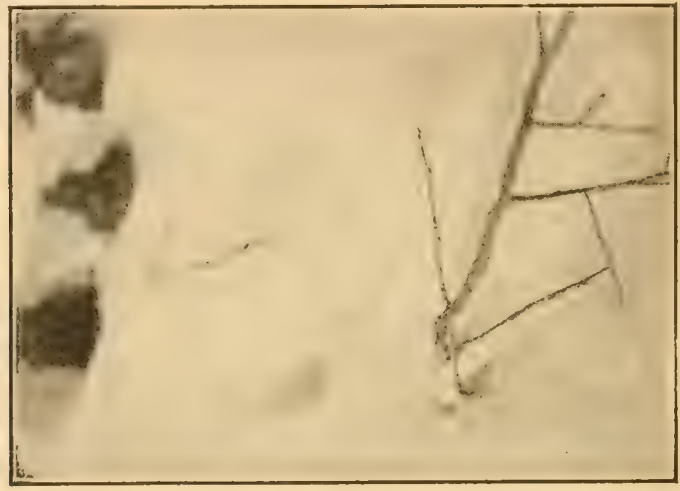

The Boys Found the Tracks of a Rabit

the wind had drifted little hollows full of it. The bushes were bent over with a heavy, white crust frozen to their branches:

The surface of the brook was covered with ice. They could walk on it almost anywhere. But they had to watch out when they came to places where the water ran fast over stones, or down over a log. In one place like that there was no ice at all.

Spot had disappeared. They ran across his tracks beside the bank of the brook. Soon they 
heard him barking, somewhere up the slope above them.

"Let's see what he's found," said Horace.

They hurried through the meadow, climbed the fence, and crossed the field where the corn had been. At the farther side Spot was digging away in the snow at the foot of a pile of rocks. When

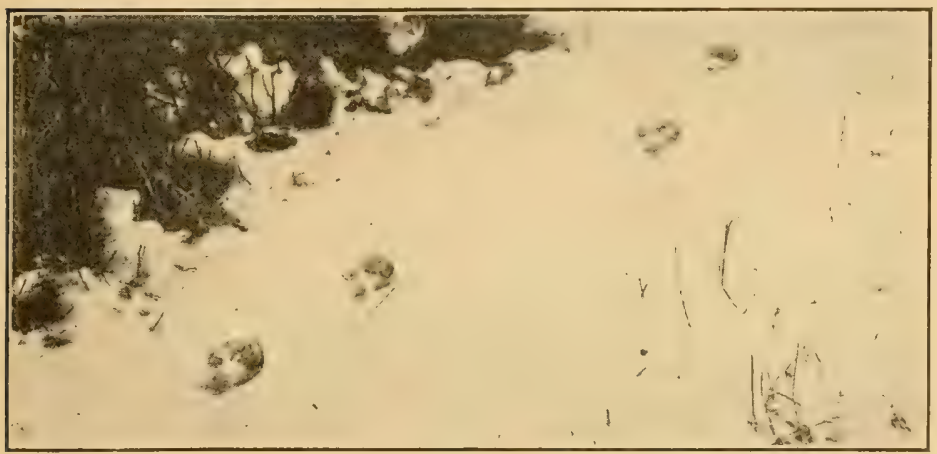

Spot had Left his Trail in the Snow

he saw the boys coming he barked and dug all the harder, sending snow and leaves flying out between his hind legs.

There was a fence beside the rocks. On the snow along the fence, and all around the rocks, were little tracks, a good deal like those that the rabbit made, but much smaller. Some of them led toward the foot of a tree near by.

Horace looked up into the tree. Then he walked around to another side and looked up from there. 
I66 JIM AND PEGGY AT MEADOWBROOK

"Spot," he called. "You foolish dog. There he is, up in the tree."

Jim looked, and pretty soon made out a red squirrel, sitting quietly on a big limb, close to the trunk.

They had a great time persuading Spot to give up digging. He couldn't get it out of his head that there was a squirrel in the rocks, waiting to be dug out.

Finally they induced him to come on with them, back toward the house. 


\section{CHAPTER XXVI}

\section{THE ICE HARVEST}

"Boys," said Uncle David, a day or two later, "don't you want to go along and watch us cut ice?" "Isn't the snow pretty deep on it?" asked Aunt Lucy.

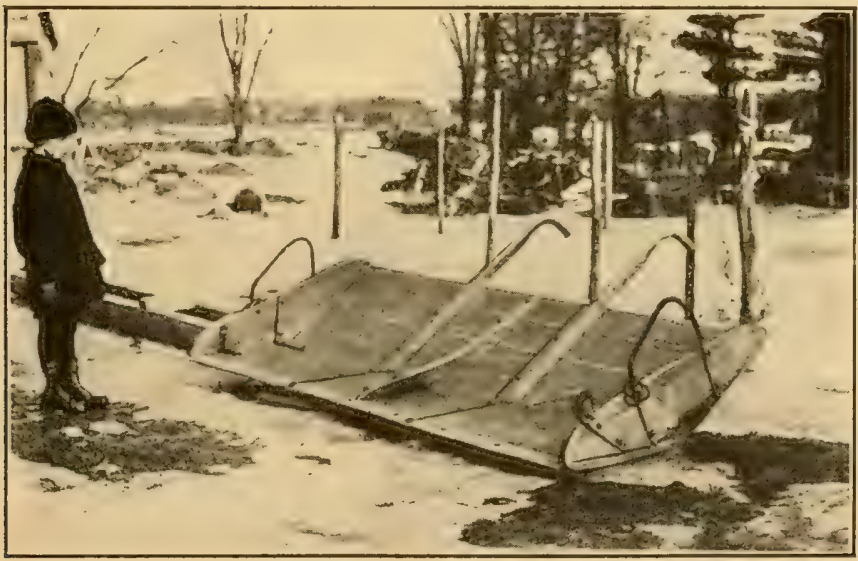

The Snow Scraper was Lying on the Bank

"Yes, there is a good deal," Uncle David assented. "But it scrapes off clean. It isn't as bad as when it thaws."

The big wagon bed had been shifted over to a 167 


\section{I68 JIM AND PEGGY AT MEADOWBROOK}

pair of heavy runners. Andy brought out Dan and Ben and hitched them up. He and Uncle David with the two boys drove away to a pond about two miles from Meadowbrook Farm.

They came out on the pond at a place where the

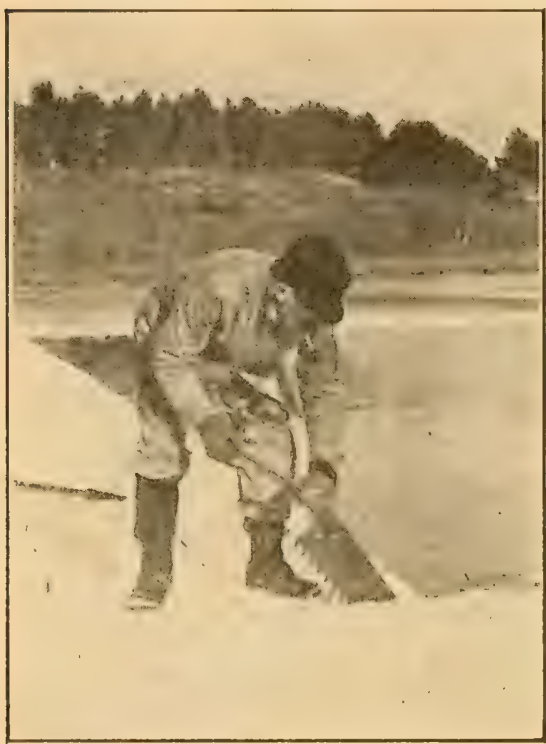

One of thl: Mren Was Sawing Ice bank was low, so that the horses and sled could easily be driven on to the ice. 'Two other teams and three men were already there. One of the teams was hitched to. a wagon on wheels instead of a sled. Jim knew one of the men Mr. Reynolds, Henry's father. The other two he had seen at a neighboring place the Sunday afternoon Uncle David took them for a walk.

Where they were at work the snow had been scraped off the top of the ice. It was piled up in heaps near by. The scraper was lying on the bank. The surface of the ice was scored with long, narrow 
furrows. Part of these ran one way, and part crossed them at right angles, so that the ice was marked off in squares.

At one end of the rows of squares there was a space of open water. In the water several icecakes were floating around. A long wooden boom

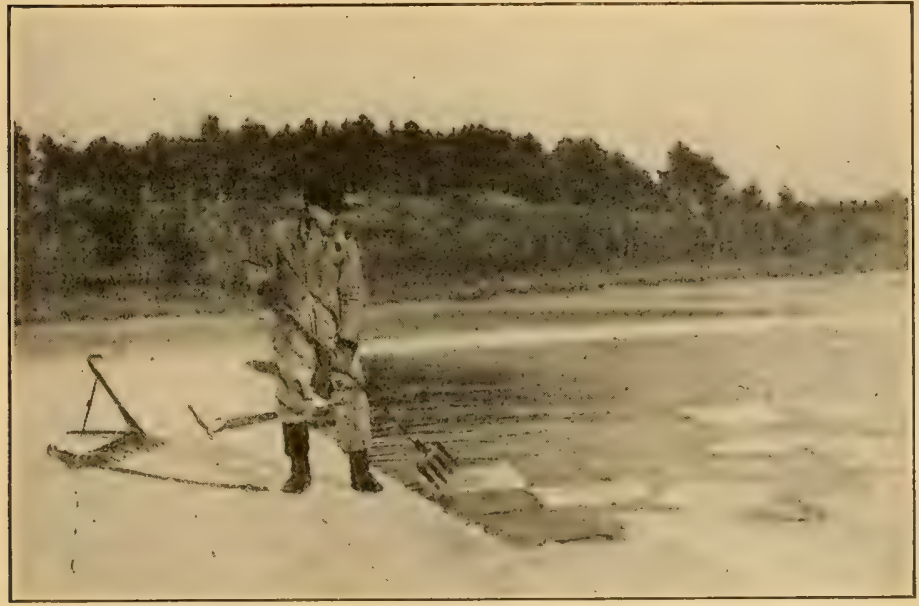

He Broke the Cakes apart with the Prongs

was lying in the water, fastened at one end with a rope. It kept the floating cakes close to the edge of the ice nearest the wagons.

One of the men was working with a big saw. It had coarse teeth, and a cross-bar handle at one end. He sawed up and down with it, along the two end furrows scored in the ice. Next he picked up a heavy iron tool, with four flat prongs on the 


\section{I70 JIM AND PEGGY AT MEADOWBROOK}

end, and jabbed it down here and there in the first cross-furrow. A row of cakes broke off. Then he used the prongs to break the cakes apart, and sent them bobbing and floating out into the water.

Mr. Reynolds stood at the edge of the ice, hold-

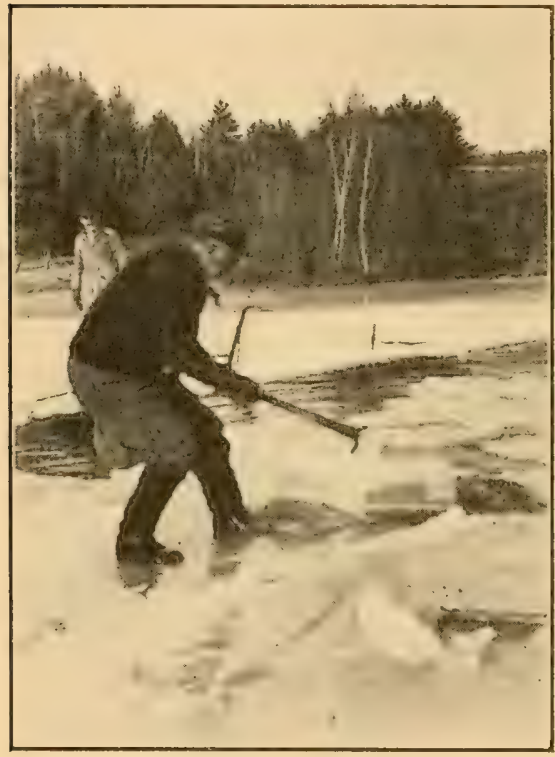

Mr. Reynolds Pulled the Cakes out ing a pole in his hands. On the end of the pole was a spike, sticking out at right angles. The ice at Mr. Reynolds' feet was cut away a little, so that there was a shallow, sloping place, running down into the water. Swinging the pole out he struck the spike at the end of it into a cake of ice and pulled it over to the sloping place. Then he tipped the cake down and up a moment, and with a quick jerk pulled it out on to the surface of the ice.

Andy and Uncle David took a hand at loading the wagon. They set a skid, so that it sloped from the surface of the ice to the wagon bed. Each of 
them hooked a pair of tongs into a cake of ice, one on each side. Then both pulled and slid it up into the bed.

All of the men had taken off their overcoats. The work kept them warm. But Horace and Jim began to feel cold. They jumped up and down and knocked their feet together.

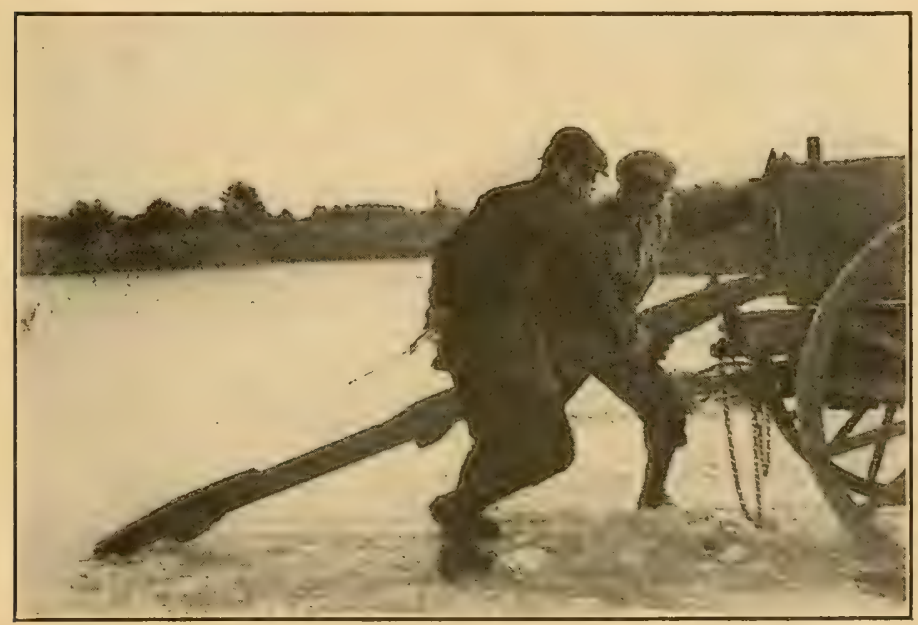

They Loaded the Wagon with Ice

"Better build a little fire, boys," suggested Andy. So they found some bits of dry bark and some sticks, and stacked them up beside an old log lying on the bank. Uncle David came over and started it going.

"Uncle David," said Jim. "What do you do with all the ice?" 


\section{I72 JIM AND PEGGY AT MEADOWBROOK}

"You mean this that we're cutting here?" "Yes,"

"It's just for our own use : for Mr. Reynolds and the others, and for Meadowbrook Farm. We aim to work together, so that each one helps the others, till we get all each one needs."

After a while they filled up the big sled that Dan and Ben were hitched to, and drove back to the farm.

The next day Jim and Peggy went back to the city. Their visit had been a short one. Jane and Horace were sorry to see them go. Before they went Jane whispered in her mother's ear:

"Can't Peggy stay a little longer?" she asked, "just over New Year's?"

"I'm afraid not," said Aunt Lucy.

Horace pulled his father to one side. But Uncle David shook his head.

"It would be lots of fun, Sonny," he said, "but - wait a minute _ "

He walked over and talked a moment with Aunt Lucy. She smiled and nodded.

"I'll tell you, children," he said. "We'll ask Peggy and Jim to come for another visit in the spring, as soon as school's out. And this time," he added, "we want them to bring their father and mother with them." 


\section{CHAPTER XXVII \\ SPRING}

The winter slowly came to an end. The wheat in the field back of the barn looked fresh and green

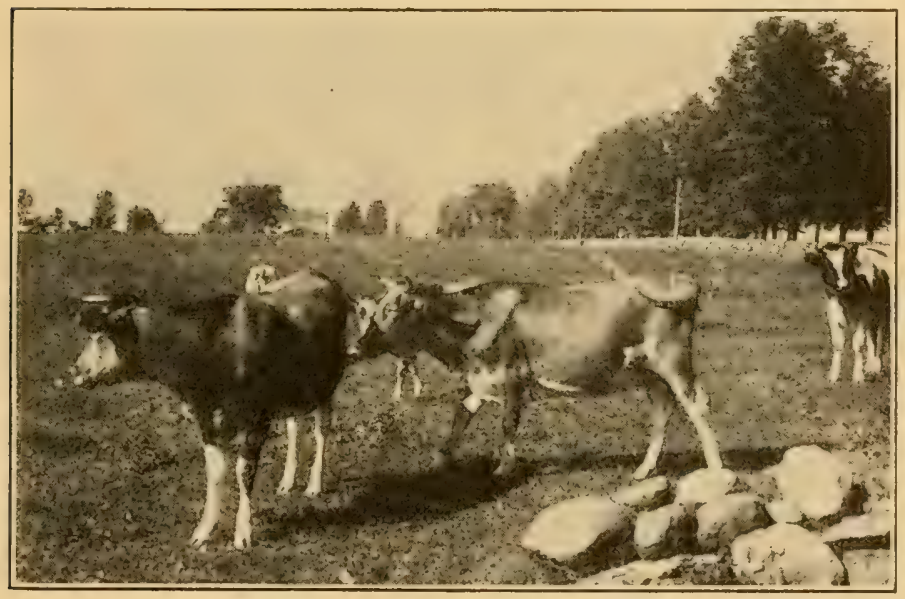

The Cows were Turned out into the Pasture

as soon as the snow was gone. Here and there in other fields the grass began to turn green. Down by the brook the buds on pussy-willows sprouted out into soft, gray tufts, like tiny rabbit-paws. Queer, slender blossoms came out on the poplar trees. Robins commenced to walk around the 
slope by the garden, hunting for worms. Jerry's feathers looked fresh and bright, as if he'd bought a new coat. A pair of bluebirds fought with sparrows, to see who should occupy the little wooden house nailed to a limb of the big apple-tree. Jane put thirteen eggs under Speckle, the hen,

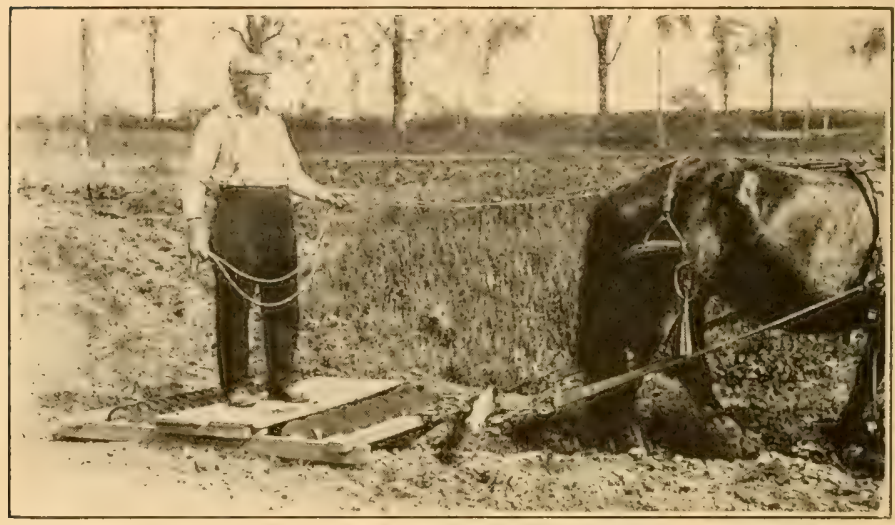

Uncle David Harrowed the Gakden

and Speckle settled down for a long stay in her nest, to keep the eggs warm and hatch out a family of chicks. Horace went fishing, at the old mill. There were three or four new, little calves in the barn. Andy let Dan and Ben out in front of the barn, and Ben lay down and rolled clear over, back and forth, six times.

"That makes him worth six hundred dollars," Andy declared.

The cows were turned out into the pasture 
across the brook. Belinda promptly found a place in the fence where she could squeeze through. She started at once for the woods, as if she were going to catch a train at Milford. Horace wasn't on hand this time, but Andy saw her. Spot saw her, too. Then Andy had to run fast enough to catch both Spot and Belinda.

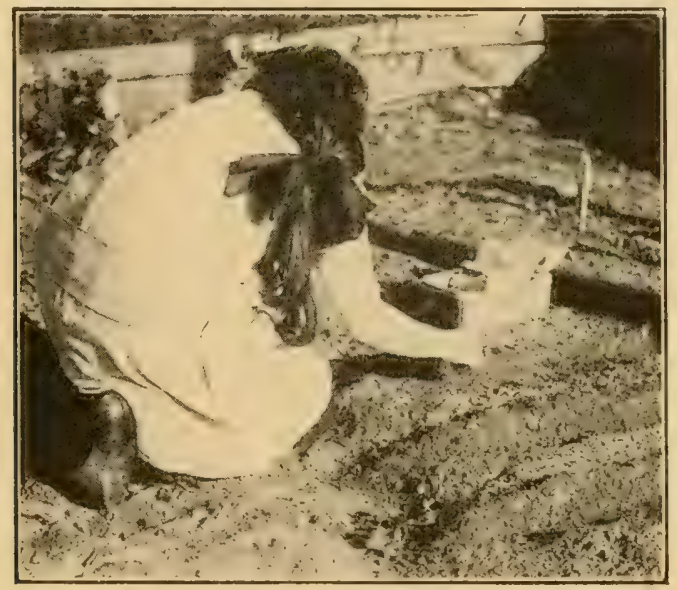

Jane Helped in Planting the Garden

Uncle David and Andrew hauled out half-adozen loads of manure and spread it on the garden. The ground there drained out quickly in the spring. That helped to get the soil into good shape early, while some of the fields were still too wet to be worked. The garden sloped toward the southeast, too, so the sun warmed it up quickly. 
I76 JIM AND PEGGY AT MEADOWBROOK

A few days later Andy plowed the piece and harrowed it. Then he and Uncle David, with Jane and Horace for helpers, took a ball of cord, laid out the rows for the early vegetables, and made the first planting of seeds.

Jane asked Horace to spade up her flower garden

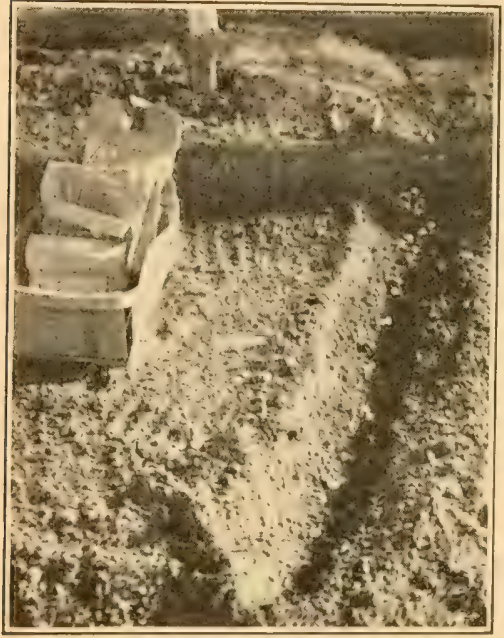

Sweet Peas were Planted for her, between the porch and the driveway. Aunt Lucy and she had bought the seeds for it in Freeport, early in the spring. As soon as the ground was ready she dug a trench along one side of the plot, and planted a row of sweet peas. Next to these was a bed for nasturtiums.

In the house she had already started several boxes of plants that needed to grow indoors for a while and then be moved outdoors. Some of these she transplanted now. The others would have to wait until warm weather, when there was no more danger of frosts.

Before long the days' grew pretty busy for everybody. As Uncle I avid said, "The day lasts only 
from sun-up to dark, but the jobs keep on growing all day and all night."

Horace and Jane usually got back from school about four o'clock. From that time until supper there were a dozen things to be looked after. Horace declared one afternoon that there were "about a million," but that was when he and Henry Reynolds had been talking about going fishing.

Speckle had brought out her family of chicks, eleven of them. Jane watched them and fed them, until they were old enough to look out for themselves. In other coops in the orchard there were other little families, scurrying out and in, scratching and hunting for bugs, while the old mother hen clucked and scolded.

As soon as the first tiny plants began to appear in the garden, the weeds, too, started up. Horace had to get after them. Part of the work he could do with the hoe, and that went along pretty fast; but part he had to do on his hands and knees, pulling up the weeds carefully so as not to disturb the plants, and that part didn't go so fast.

All the time the sun kept getting higher in the sky each day, the leaves grew larger on the trees, and the grass kept growing greener. 


\section{CHAPTER XXVIII}

\section{PLANTING-TIME}

As soon as the ground had dried out enough, Andy set to work plowing the field across the brook. When he had it about half done, a big rain storm drove him in. Then for a week it rained just enough to keep the ground so wet that Andy couldn't finish. In the afternoon the sun would shine, but next morning it would be raining again. Or, if the sun came out in the morning, there would be a storm in the afternoon.

Andy fretted and complained. "Looks as if it was going to keep on raining for a month," he grumbled. "First thing we know it'll be summer, before we get that piece plowed."

"Why don't you try it anyhow?" said Horace. "Then I'd have a pretty how-de-do, now wouldn't I," snorted Andy. "If you go on that ground when it's wet, you won't get rid of the clods till next winter."

Finally there were good days of warm, drying sun, and Dan and Ben finished their rounds. The next day Andy began harrowing. He used a disk 
harrow at the start. It was a good deal like the cutaway that Jim had seen Mr. Reynolds using, but it wasn't as large, and there were no notches cut in the edge of the disks. Back and forth, and criss-cross up and down, Dan and Ben pulled the

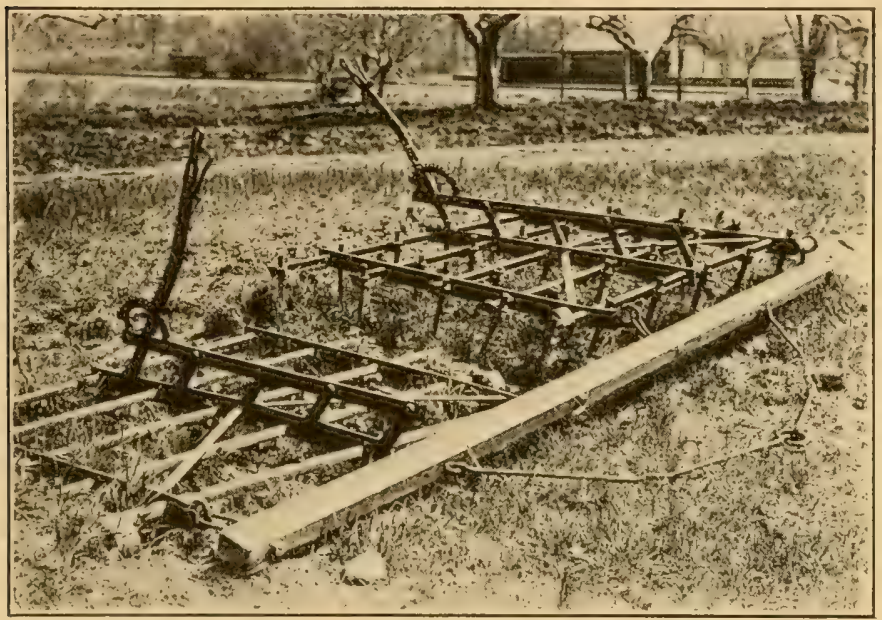

Andy Went over the Field with a Spike-tooth Harrow

harrow, stirring up and smoothing out all the ridges left by the plow.

Next Andy went over the field with the spiketooth. There wasn't any seat on this harrow for Andy to ride on. He walked along back of it. The harrow was a low, wide, iron framework, set every little way with long iron spikes that stuck down beneath. There were handles on it that you could move forward or back. When you 
moved these it made all the spikes point straight down or slope toward the rear.

There was one part of the field, toward the lower corner, where water had stood in winter. When Andy had finished with the spike-tooth, the earth was still

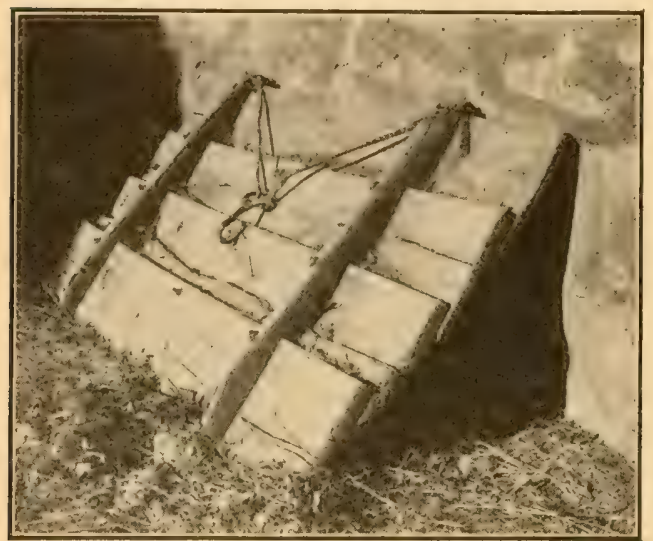

The Drag was Made of Heavy Planks lumpy in this part. Many of the lumps were hard, almost like stones. The spikes didn't break these up. They only pushed them aside, and stirred them around.

To get this place into good order Andy went over it with a drag. The drag was made of four heavy planks bolted to cross-pieces. The edge of each plank was set a little way over the one next to it, like shingles on the roof of a house. On top of the drag were stones, to weight it down. As Dan and Ben pulled the drag along, the planks crushed the hard lumps, mashing them into bits.

Finally the field was ready for planting. The ground was mellow and crumbly. You could push 
your foot down into it almost to the top of your shoe.

Uncle David hired an extra team of horses for a day or two, with a man to drive them. There was a farm half a mile away that was willing to spare them.

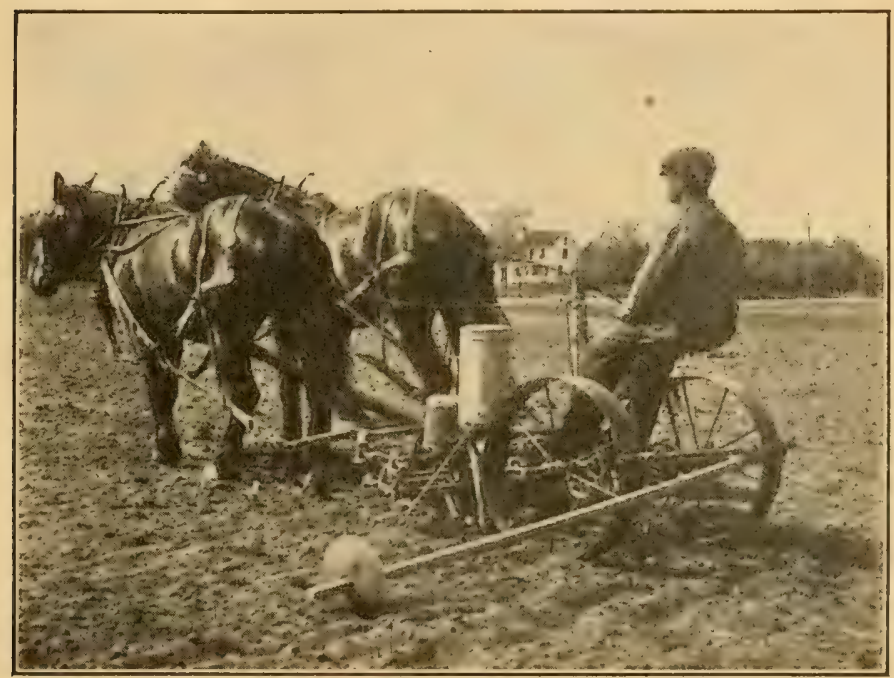

They Planted the Piece to Ensilage Corn

"They won't do as much work as Dan and Ben," said Andy, "but I suppose they'll help out."

The new team went to work on the field that Uncle David had plowed in the fall. It was ready now to be harrowed. As soon as it was in good order Uncle David got out the corn-planter. Then he and the new man planted the piece to 


\section{I82 JIM AND PEGGY AT MEADOWBROOK}

ensilage corn. They took a good deal of care to get the first row straight. After that the planter marked out the next row each time. But the driver had to be careful to follow the mark.

Meanwhile Andy brought out the drill from the tool shed, and seeded part of the field that he had

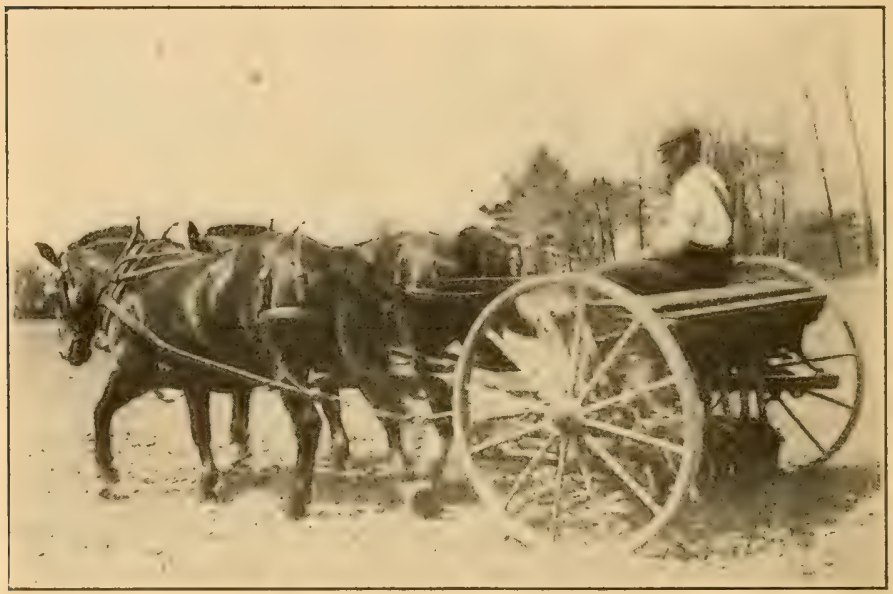

Andy Seeded down the Field across the Brook

been harrowing, across the brook. The drill had two wheels, with a long box, cross-wise, just over the axle. This was where Andy put the seed. Beneath the box was a row of eight pipes, leading down. Each pipe ended in a sort of iron boot. The boots ran through the ground, with their bottoms a few inches below the surface, and the seed fed down through them. 
There had been no rain now for a week or more. The sun was hot, and the top of the ground was dried out. So Andy took Dan and Ben and rolled the field, to make the moisture, farther down in the ground, come to the surface, and help the seed to sprout.

Before long the plants where the seeder had

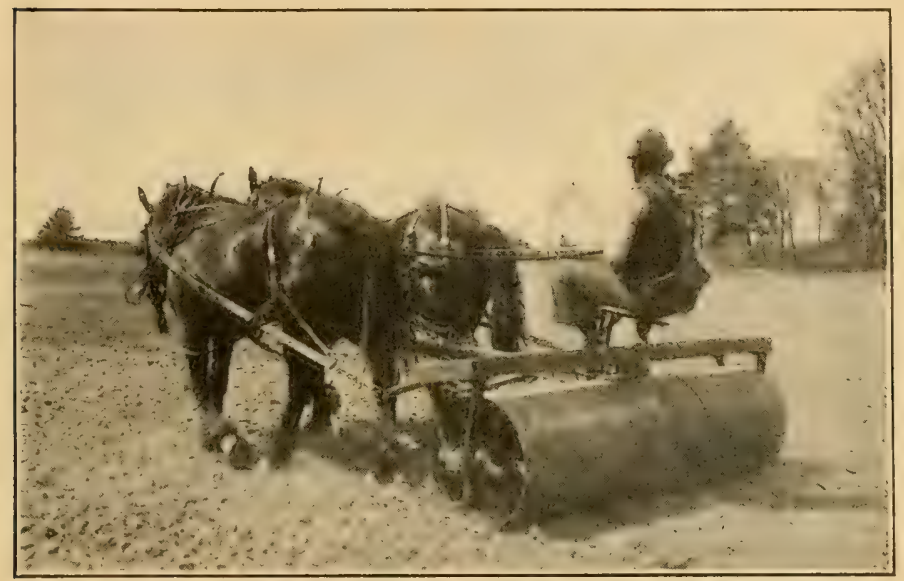

The Roller Made the Moisture Come to the Surface

been were through the ground. A rainy day came along, and set them sprouting up in a hurry. If you stood off at one end of the field and looked up the slope, you could see each row. The wheat was growing fast. The corn was up.

The weeds, too, kept shooting up everywhere. They kept Andy busy with the cultivator and made Horace work hard with his hoe. 


\section{CHAPTER XXIX \\ UNCLE JOHN AND JIM}

Toward the end of May the school at the fork of the road closed for the summer vacation. There were so many things to be done on the farms

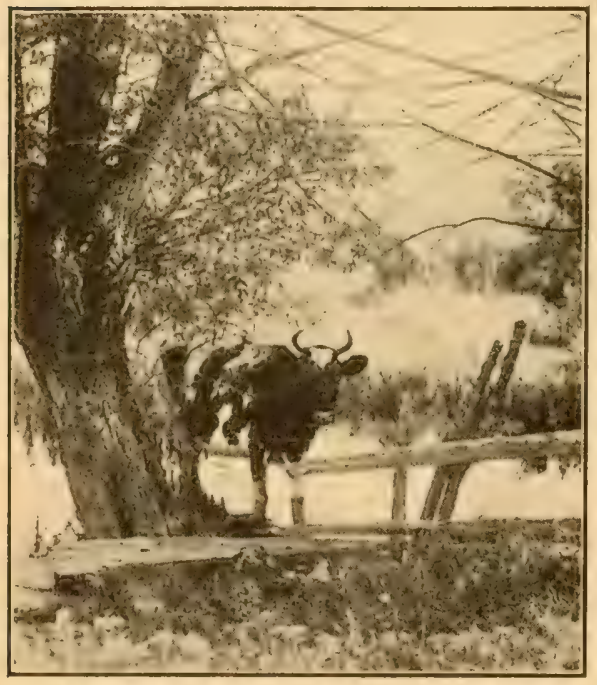

Near the Bridge a Cow Stood in the WATER at that time of year that the older children were needed at their homes.

Peggy wrote that their schools in the city would close in about three weeks. She and Jim would finish their work the fourteenth of June. A few days later Uncle John, Peggy's father, received a letter from Uncle David. In the same mail word came from Aunt Lucy for 184 


\section{UNCLE JOHN AND JIM}

Peggy's mother, Aunt Emily. There were more letters and answers. Finally it was arranged that Jim and Peggy, with their father and mother, should come to Meadowbrook Farm soon after school closed, for a two weeks' visit.

They came one clear, warm day, the last of June. Uncle David drove to Milford with Milly to meet them. They had taken the morning

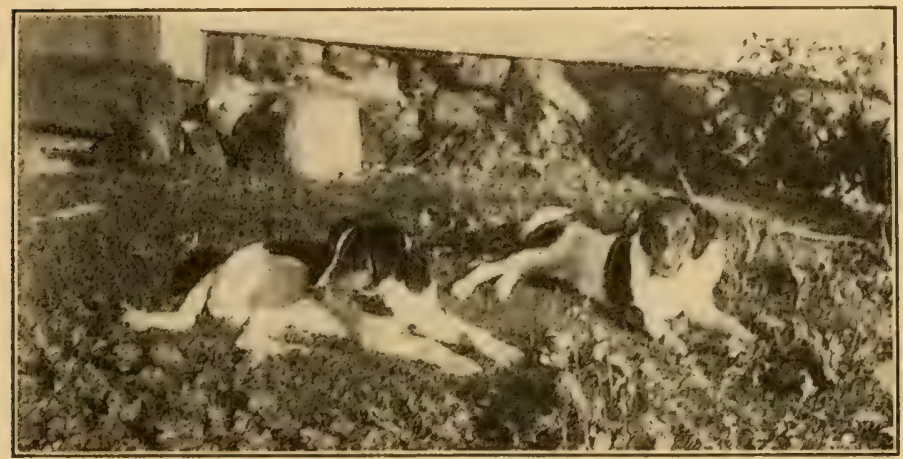

Around the Corner They Found Spot and Tag

train, reaching Milford at eleven o'clock. Almost before the train had pulled out, Milly was headed toward home, and soon she had turned the corner into the long level stretch. The sun shone brightly, making black shadows on the road where the trees arched overhead. In the marshy place by the bridge a cow stood in the water, switching her tail to drive away flies.

Just before they reached the top of the long hill 
Jane and Horace met them. Uncle David stopped the horse, and Jim and Peggy jumped out to walk down the hill with the other children. Near where they stopped Uncle John pointed out a farmhouse to Aunt Emily.

"That's the place," he said, "I haven't seen it since I was a boy."

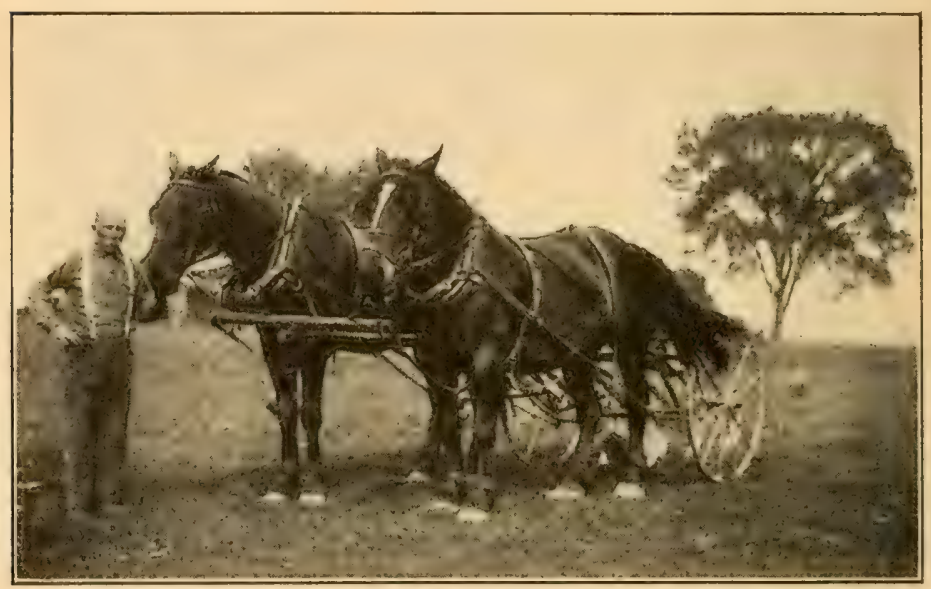

Andy Hitched Dan and Ben to the Cultivator

Dinner was all ready when they arrived. Hannah Wiggin had come over, to help Aunt Lucy. As soon as dinner was finished, Uncle John slipped into a pair of overalls, and found an old straw hat.

"Come on, Jim," he said, "let's see the farm."

Around the corner of the woodshed they found Spot and Tag. 
"Hie, there, Spot," called Jim, "Hello, Tag."

Both dogs got up, wagging their tails. But it was a warm day, and they were too lazy and comfortable to go along.

Andy had backed the cultivator out of the toolshed and was getting ready to spend the afternoon fighting weeds in the cornfield. They watched him while he brought out Dan and Ben, and hitched them up.

"These are t w o $\mathrm{n}$ i c e horses, Mr. Harlow," he said.

Uncle John looked them o ver. $\mathrm{He}$

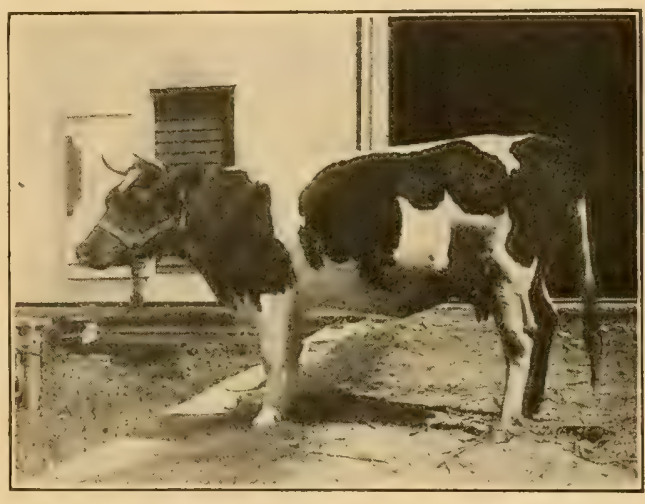

There was a New Holstein rubbed his hand up and down their noses.

"What'll they weigh?" he asked.

"They weighed twenty-eight hundred this spring," Andy replied, “but I think they're a little lighter now." He turned to Jim.

"Did you see our new cow?" he asked.

He tied Dan and Ben to a corner of the toolhouse, and disappeared into the barn. In a moment he came out, leading a big black and white Holstein. 
"We just brought her over this morning," he explained. "We traded for her. Belinda was a good milker, but she never could learn what a fence was for. If there wasn't any hole for her to get through, it seemed as if she'd make one."

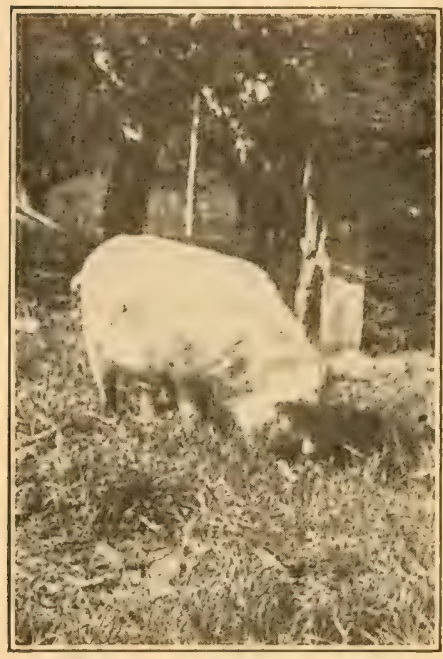

Jim Found a Big White Pig

At the farther end of the orchard Jim and Uncle John found a big white pig, rooting a round in front of a low shed, inside a wire fence.

"That looks like Nellie," said Jim. "I wonder where her little pigs are."

"Maybe her family's grown up by this time," said his father. "Pigs grow pretty fast."

They camè back through the farmyard, and walked down the path to the plank bridge over the brook. Jim showed his father the ram and the spring, and told him how the brook worked to pump the water from the spring to the house.

A little way beyond they came to a gate, and turned into the field that Andy had plowed and seeded, earlier in the season. It was all green, now, with grass and clover. 


\section{UNCLE JOHN AND JIM}

"This is the place where the corn was," said Jim. "Over there's the tree where I saw the squirrel.",

He led the way across the field. The clover was higher than their shoe-tops, and felt soft beneath their feet. Uncle John stooped and ran his hand through the thick leaves.

"It's a fine stand," he said. "You don't always see clover as good as this."

At the fence, on the farther side, they came to a pile of rocks. There were bits of old shells lying about. Jim looked up into the hickory tree.

"There he is," he said. "Old Spot never got him, after all." 


\section{CHAPTER XXX \\ ACROSS THE FIELDS}

Jim and his father walked on alongside the fence until they came to the corner of the field. There was a sort of gate there, leading into another piece. But the gate didn't swing. It was made of three

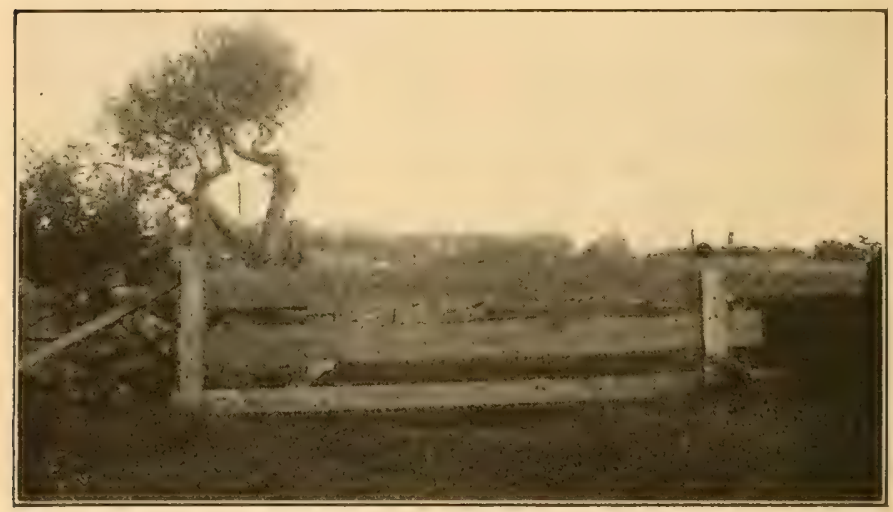

There was a Set of Bars at the Corner

long boards that rested at each end on cross-pieces nailed between a pair of posts, set close together. The boards were loose, so that you could slide them out and lay them to one side if you wanted to drive through, 
"This is what we used to call a set of bars," said Uncle John. "I remember there was a set where you went into our back pasture. Only, they were made of poles, instead of boards like these. They were pretty heavy to lift down and put up again."

"Where was your place, Dad ?" asked Jim.

"Why, don't you know? It was that farm at the top of the hill, where Horace and Jane met us yesterday."

"I didn't know you used to live there," said Jim, surprised.

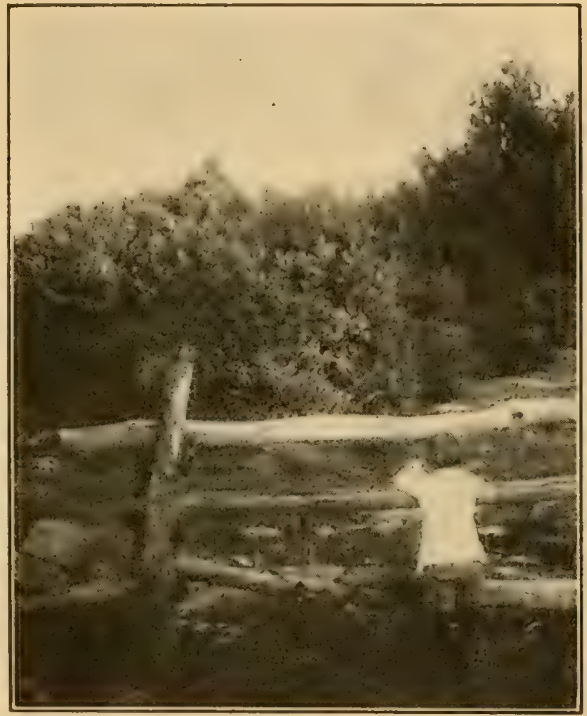

The Old Bars, Made of Poles

"Yes," said Uncle John, "we lived there until I was about nine or ten - about as big as you. Then my daddy sold the place, and we moved to the city."

Uncle John climbed up on the bars, and sat on the top one. Jim climbed up beside him. Beyond them was a low stone wall. On top of it were long 
I92 JIM AND PEGGY AT MEADOWBROOK

poles held in place by other shorter cross-poles set in the ground, on either side of the wall, and resting against it.

"That's an old-time fence, Jim," said Uncle John. "But it isn't as queer as the stump fences that we used to have, in some places."

"What do you mean by stump-fences?" asked Jim.

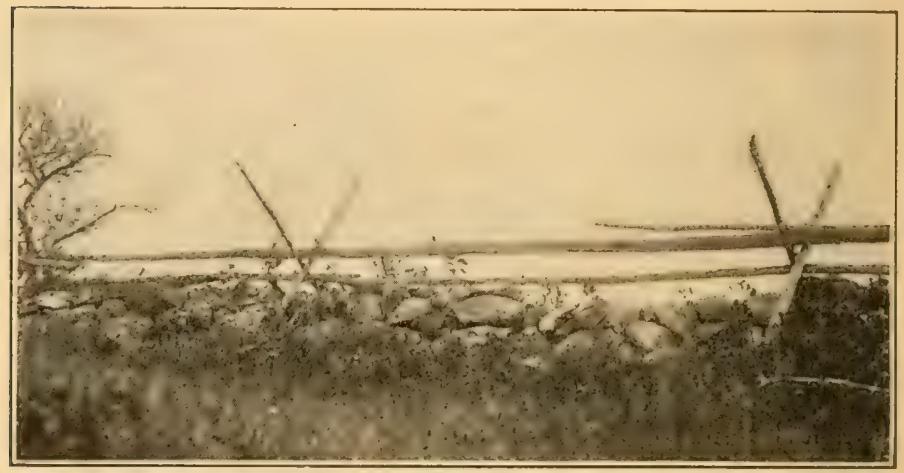

On Top of the. Wall were Long Poles

"They were made of stumps turned over on their sides," explained his father. "The roots were fast to the stump. When you set them close together all these roots stuck up in the air and crossed each other and made a sort of fence. Then you filled in any holes with rails or logs."

They watched a big, black crow go flapping along overhead. A sparrow was flying just behind the crow, darting at him first from one side and then from the other. 
"Sec the sparrow chasing the old corn-thief," said Uncle John.

After a while they climbed down on the farther side of the bars and walked across a wide pasture. At the other end men were at work putting up a wire fence. The posts for the fence were already set and braced. One of the men had an

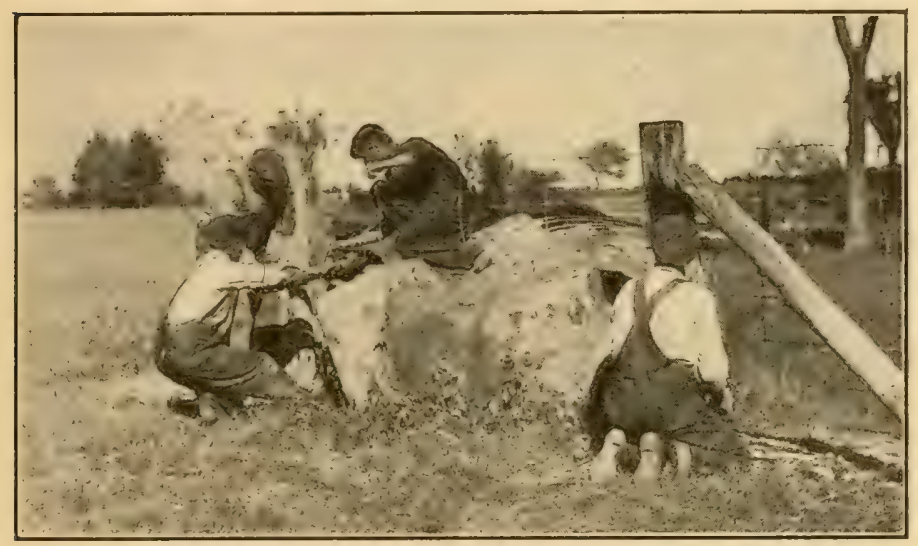

Sone Men were Putting up a Wire Fence

iron clamp that he fastened to the wire. Then he rested a part of the clamp against a post, and pulled on a handle that stuck out from the clamp. That stretched the wire tight while another man drove in staples to fasten it in place. The wires near the ground were closer together than those farther up, and there were cross wires, running up and down, every two or three feet.

"That makes a good fence," said Uncle John. 
"Might as well put up a good one while you're about it," replied one of the men.

"Uncle David has some fences like that," said Jim, as they walked away. "He has some good gates, too. One of them, up by the barn, has a stone post at the end of it that's higher'n your head."

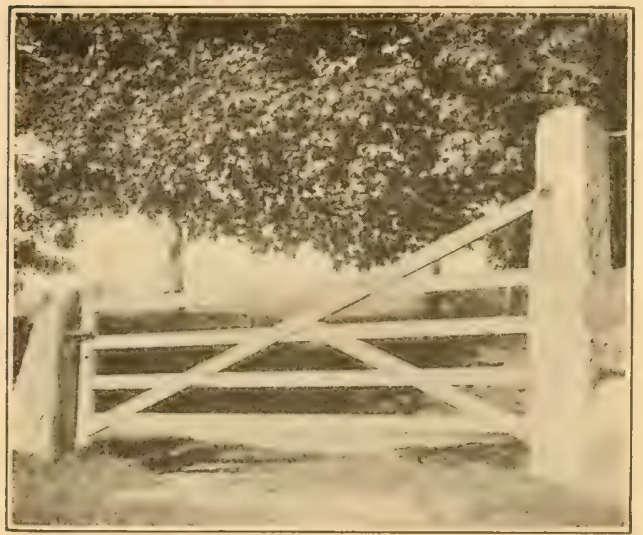

The Gate with the High Stone Post

They came back along the bank of the brook. Jim led the way to a fallen tree where they could cross. "Any fish in h e re, son?" asked Uncle John.

“Sure," said Jim. “Don't you remember I told you about the fish we caught last fall? That was down below here. There's an old dam down there."

"Let's go and see it," said his father.

So they crossed back over the fallen log, and tramped on down to the dam. Jim pointed out the spot where they had fished first, where the shiners ate off all their bait; and the other place, at the dam, where they caught their fish. 
There was a pole, without any line on it, leaning against the side of the old mill.

"There's my pole," said Jim. "I left it there when we started back home."

Uncle John looked up and down the brook, and chuckled to himself.

"I guess I know the place, after all," he said. "My daddy brought me here fishing when I was ? kid." 


\section{CHAPTER XXXI}

\section{AUNT EMILY AND PEGGY}

After Jim and his father had started for their walk, Peggy and Jane took Aunt Emily to show her the chickens and little pigs, and the calves.

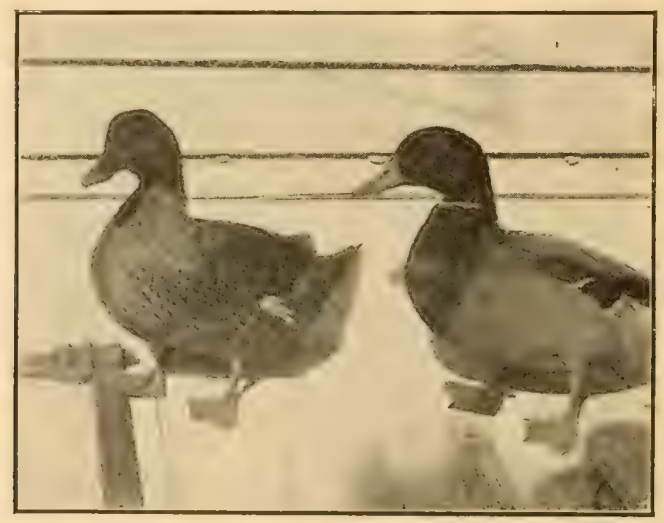

Brownie and Jerry Were on the Cellar Door

They stopped first to hunt up Brownie and Jerry, and found them on the other side of the house, sitting on the cellar door. As usual, Jerry was suspicious. He wanted to get down from the door. But it was too high to jump from the upper end, where he was sitting, and the visitors were stand- 
ing at the lower end. All he could do was to say "Quirk-quirk."

Lying in the sun, by the wheels of the old buggy, in the tool-house, were seven or eight little white pigs. They squealed and grunted, and ran away.

"Where's Nellie?" asked Peggy, as they came near to a shed that had boards fastened across the doorway.

' Who is

Nellie ?" inquired Aunt Emily.

"Why, don't $\mathrm{y}$ o u k n o w ? She's the big white pig that always stood up by the door in that shed, and hung her leg over the boards. Those were her little pigs that

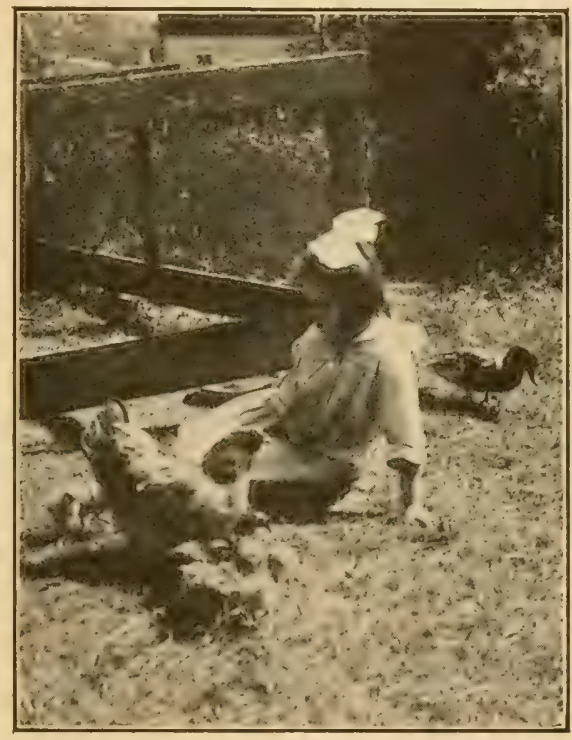

There were Several Families of Littie Chicks

we saw back there by the buggy wheel."

Jane laughed. "Why, Peggy," she said, "Nellie's pigs are all grown up. We sold them last week."

Peggy was astonished. 
"Well, those pigs are just like them, anyhow," she declared.

They looked over the boards into the shed. Another big pig, almost like Nellie but not quite as white, was lying on the floor. She had a family of very small pigs of her own.

There were other families of youngsters near by. Scattered through the orchard were several small houses, each about two feet high. Some had

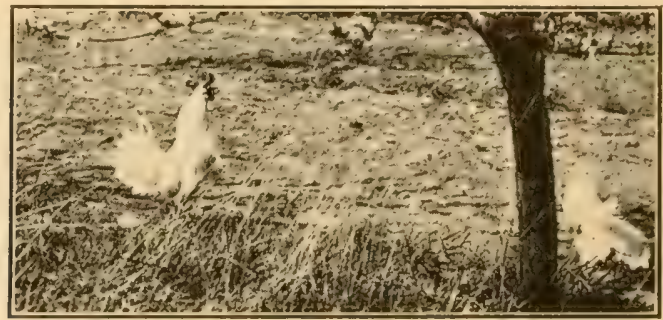

Hiram was in One of the Chicken Yards

shingles on the roof, some had tarred paper, and one had white oilcloth. Around each house a dozen or more little chicks were scampering, while an old hen stood guard over them.

"I see Hiram," said Peggy.

"She ran into one of the chicken yards and "shooed" a white rooster toward the fence. They waited for him to crow, but he wouldn't perform. When they turned to go away he raised his head, flapped his wings, and crowed twice.

"Is Susan here yet?" asked Peggy. 


\section{AUNT EMILY AND PEGGY}

199

"She's in the pasture," said Jane. want to walk out there, Aunt Emily?"

"Do you

Aunt Emily was willing. "I know who Susan is," she said.

Jane led the way through the gate, down the lane, and through the bars into the pasture.

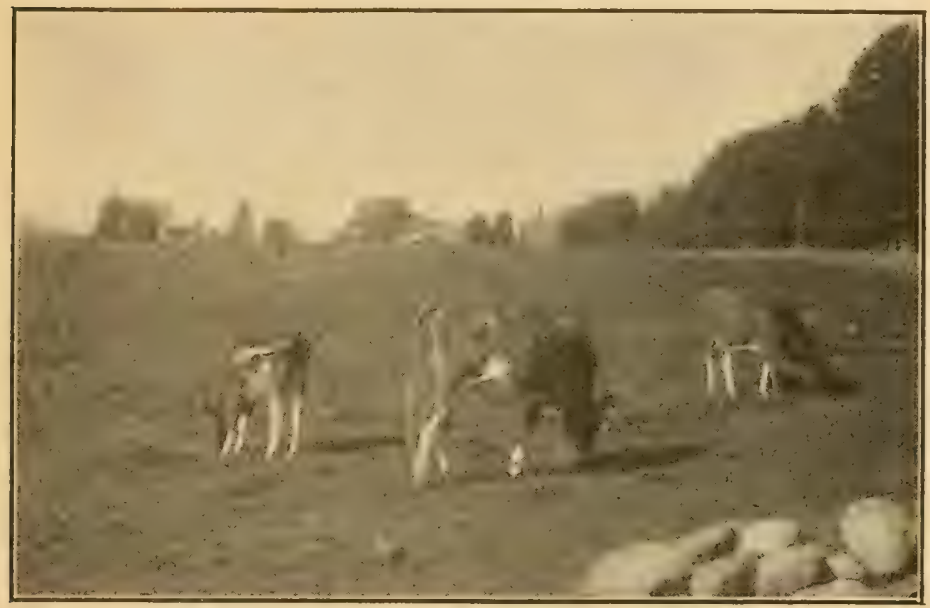

Beyond a Knoll were Three Calves

Beyond a little knoll they found three calves. One of them was Susan. But she had grown so much that Peggy hardly knew. her. She was taller, and rounder, and her horns had begun to show. She wasn't tied to a pole any more, but wandered along with the other calves, eating grass.

There was a tree on the knoll, and a pleasant, 
shady place. Aunt Emily and the girls sat there for a long time, watching the calves and talking about the farm and the school, and the things that they had been doing. When they got back to the house the afternoon was nearly over.

As they stepped up on the porch Aunt Lucy

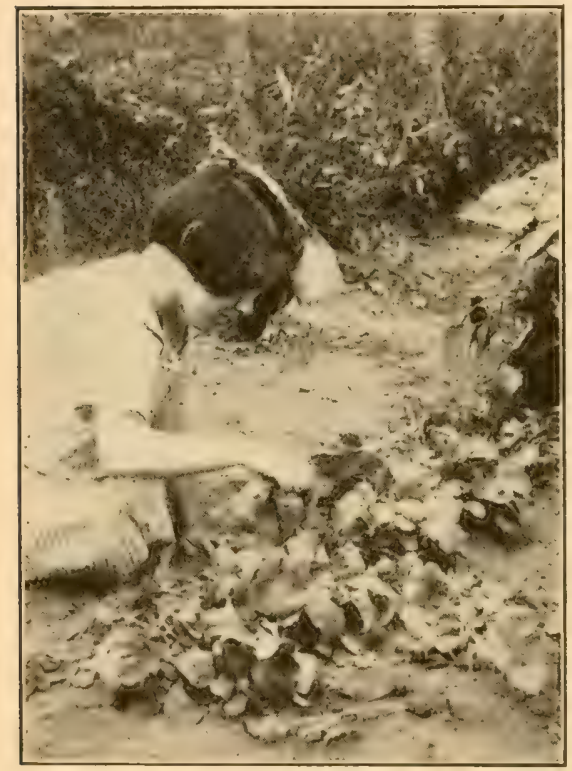

Peggy Found a Bed of Radishes

came out with a basket, on her - way to the garden to get vegetables for supper. "Can't I go ?" asked Peggy.

"All right," said Aunt Lucy, "you and Jane bring in some things."

The girls crossed into the garden and walked along the rows. Peggy found a bed of

little red radishes, and gathered a bunch of them. Jane added two big heads of lettuce. There were bean-vines close by, some of them full of clusters of long, yellow pods. They filled one end of the basket with a heap of these. 
"Let's pick some strawberries," said Jane.

She ran into the house and brought out another basket. The two girls got down on their hands and knees, among the strawberry vines, and hunted out the ripest and darkest berries, hidden away beneath the leaves.

Peggy carried the berries to the porch, to show

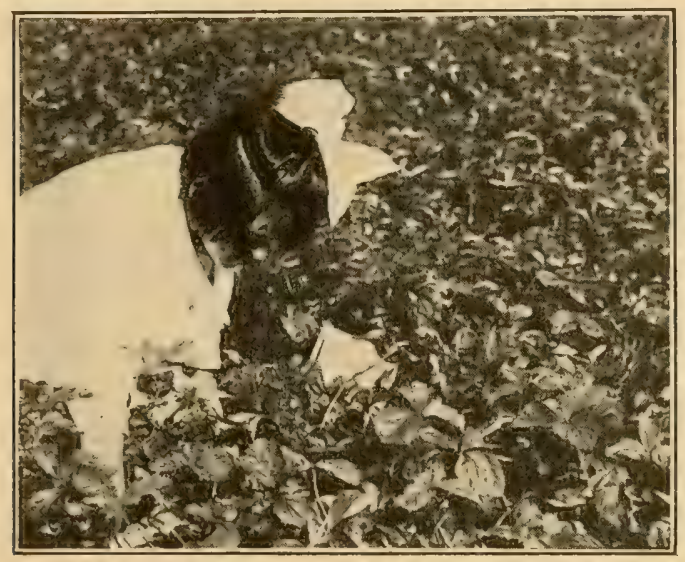

They Hunted for the Ripest Berries

them to her mother. Then she and Jane took them into the house to hull them. Aunt Lucy and Hannah Wiggin began getting supper.

After a time Peggy came out and joined Aunt Emily on the porch. She sat down on the arm of her mother's chair, and a moment later slipped into her lap.

They watched the twilight deepen across the 
202 JIM AND PEGGY AT MEADOWBROOK

meadow. Somewhere near the barn they could hear Jim and Uncle John talking together.

"I wonder," said Aunt Emily, "how my Peggy would like to live on a farm ?"

"I surely would," said Peggy. 


\section{CHAPTER XXXII OLD AND NEW}

WHEN Jim and his father came back to the farmyard, they found Uncle David and Horace at work setting up a post at one side of the open space between the house and the barn. On top of the post was an iron bracket holding a glass globe. .

"What do you think of our new light?" said Horace to Jim.

"What's it for?" asked Jim.

"Haven't you seen the new outfit?" said Uncle David.

He led them around to the farther side of the house, where there was a short, steep bank. In the side of the bank a shed had been built, with the roof coming down almost to the ground, like a root-cellar. On the side next to the slope there was a door.

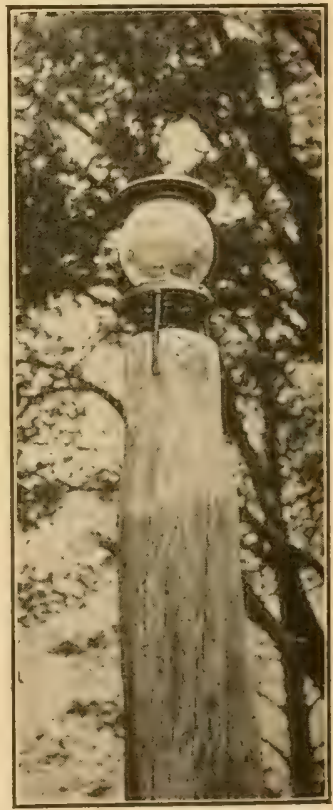

There was a Post with a Globe on Top 


\section{JIM AND PEGGY AT MEADOWBROOK}

Horace opened the door. It was dark inside, but when Jim and his father stepped nearer they could see a thing like a tall iron can, on legs. The can was in three sections. A small pipe led from

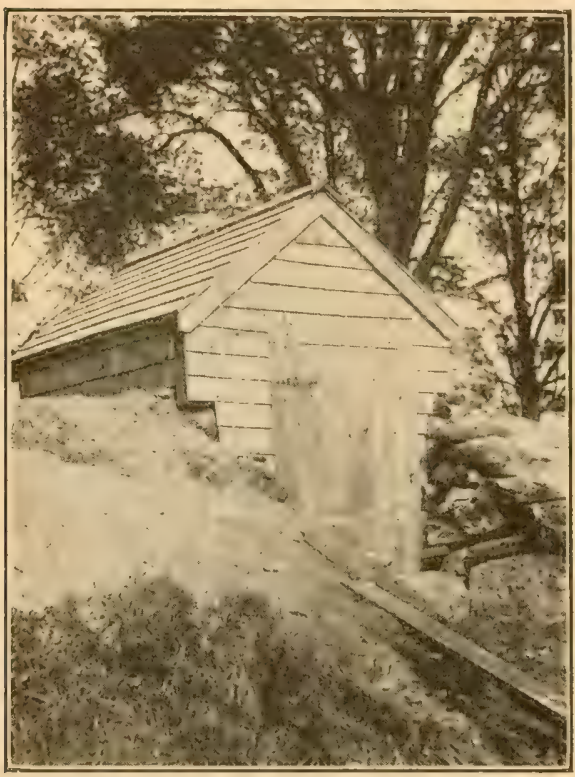

In the Bank a Shed Had Been Bullt it through the wall, into the ground.

"It's a machine to make gas for lights," said Uncle David, "an acetylene generator, they call it. We're going to pipe it all through the house and barn."

He explained how water was put into one part of the can, and a chemical into another. When the two came together the gas was formed. The machine would regulate itself, except for cleaning and filling. once in a while.

The boys wandered out through the orchard, to look up some little pigs. Uncle John and Uncle David walked back to the barn and sat down on the grassy slope, near the big doors. 
"The gas lights won't entirely take the place of oil, will they," remarked Uncle John.

"No," said Uncle David, "we'll have to use lanterns as we always have, around parts of the barn and other buildings. I expect we'll always have one hanging on the old nail there by the door. Of course the gas will be handy in the house, because it makes so much more light than a lamp. But more than likely we'll use our oil lamps a good deal at that, now and then. I don't think Jane will get out of practice at filling them.'

"How are electric light plants for farms?" asked Uncle John. "I think they're first rate," said Uncle David. "They cost a good deal to put in, I understand, but probably they're the best in some ways. Even at that, you'll have to use an

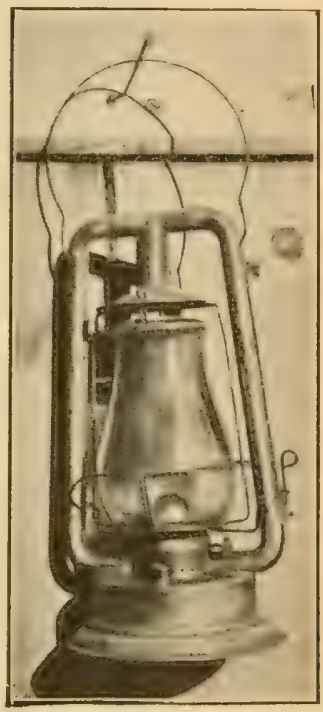

A Lantern Will Always Be NeEded oil lantern for getting around at nights: such as crossing a dark field, or looking up the stock."

The cows came walking up slowly through the pasture. The sun was getting low. It would soon be milking-time. Horace and Jim finished their inspection of the pigs, and joined Uncle 
206 JIM AND PEGGY AT MEADOWBROOK

David and Uncle John on the grassy slope near the barn.

"Well," said Uncle John, "I suppose that lots

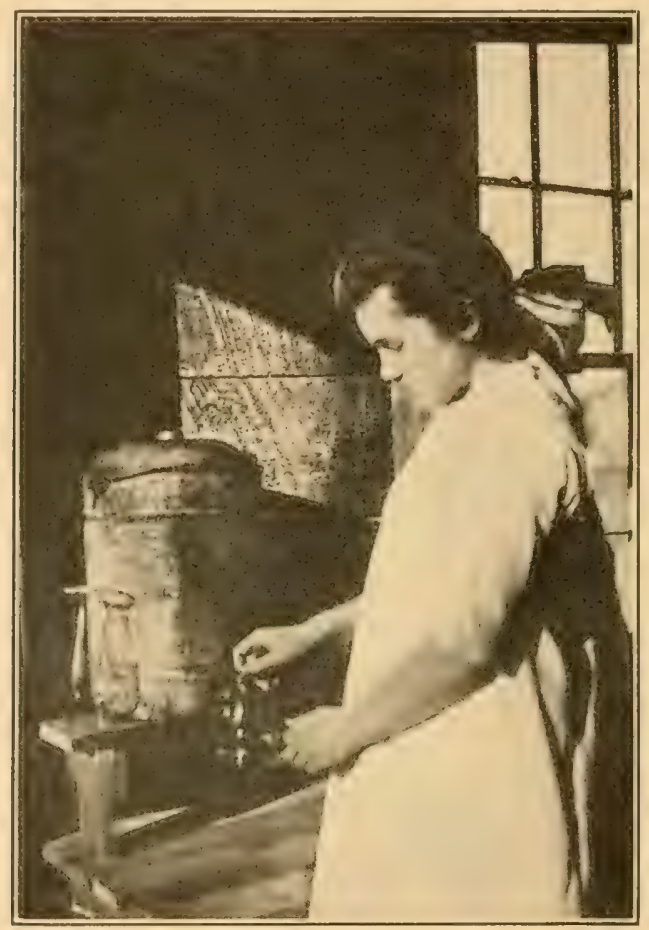

Orl Lamps for Jane to Fill

of things are changed and improved around a farm since I was a boy."

"I don't know that there are so many changes," said Uncle David. "We have pretty much the same farm tools. That cultivator over there isn't 
much different from the one my father used in his potato patch. It's made about as it used to be, and has about the same shovels to stir up the dirt and discourage the weeds. I think harvesting machinery's changed more than anything else."

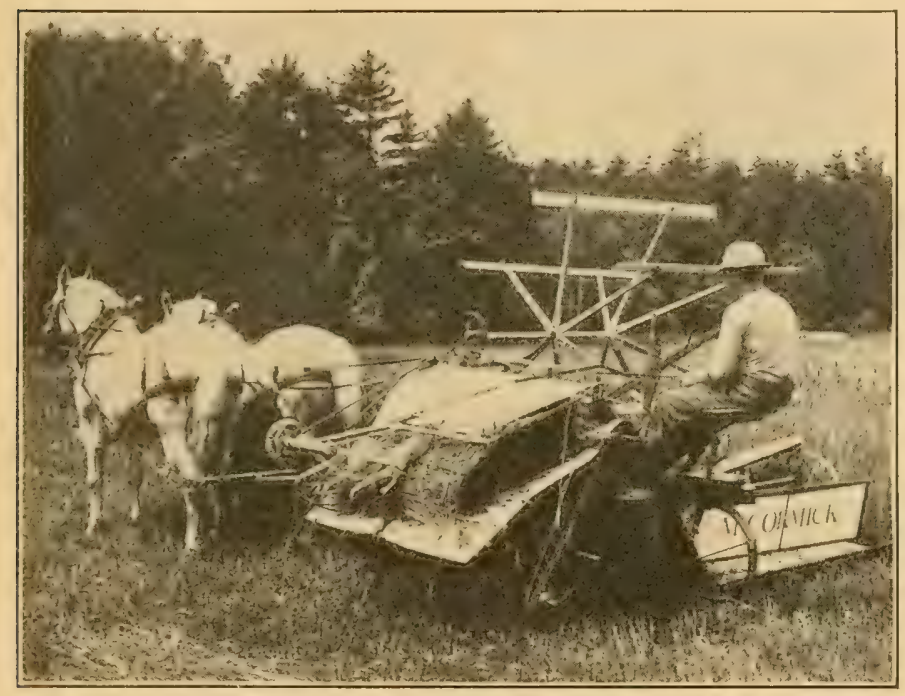

When the Wheat is Ripe the Reaping Begins

"Harvest was always a busy time," remarked Uncle John.

"It is yet," said Uncle David. "There'll be a gang of eight or ten men here for two or three days, with a traction engine and a big thresher. We don't raise very much grain, and they'll rush it through pretty fast." 
"When is harvest, Uncle David?" asked Jim.

"It comes before many weeks now. As soon as the wheat's ripe we'll be running the reaper through it. Then we'll shock it up. Pretty soon after that the threshing crew will be around. They'll set up back of the barn, and we'll haul in

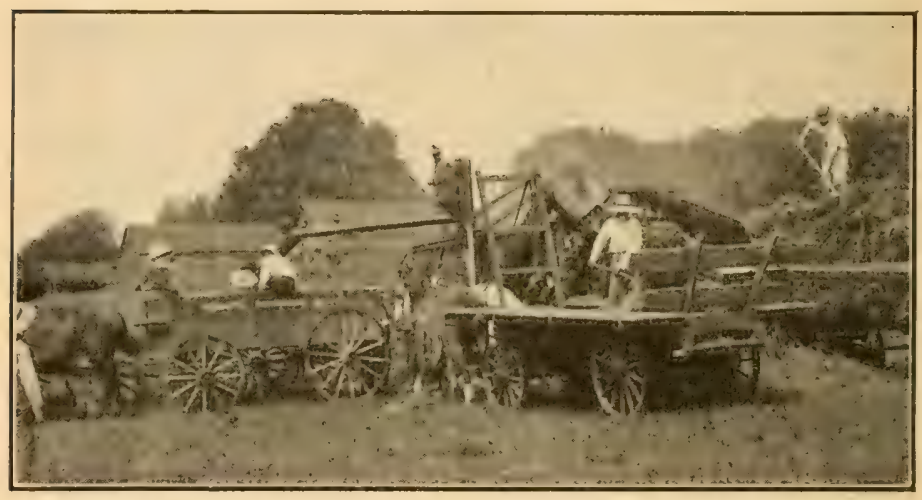

Threshing is a Busy Time

the grain, as fast as the teams can fetch it. Two men will feed it into the thresher, and before you know it the wheat'll be in the bags and the blower'll have the straw piled up in a big stack."

Uncle David disappeared into the barn to begin the evening chores. Horace went to the house, to carry in firewood for Aunt Lucy.

Uncle John and Jim sat on the grass, and watched the shadows creep across the meadow, toward the brook. A turkey stalked by, on his 


\section{OLD AND NEW}

way to join the rest of the flock at their roost. Tag wandered up and lay down beside them. On the porch they could hear the voices of Peggy and Aunt Emily. A light shone in the kitchen, and through the windows they could see Aunt Lucy and Hannah Wiggin and Jane getting supper.

"Jim," said Uncle John, "would you like to live on a farm ?"

"You bet I would," said Jim. 


\section{CHAPTER XXXIII}

\section{HAY MAKING}

A FEw days later Uncle David started mowing one of the fields. The grass was higher than Jim's knees, though it wasn't a heavy stand. The heavier, clover hay would be mowed the next week. Andy backed the mowing machine out of the tool shed. It had wide iron wheels, with cross-pieces on the rims. "Those are

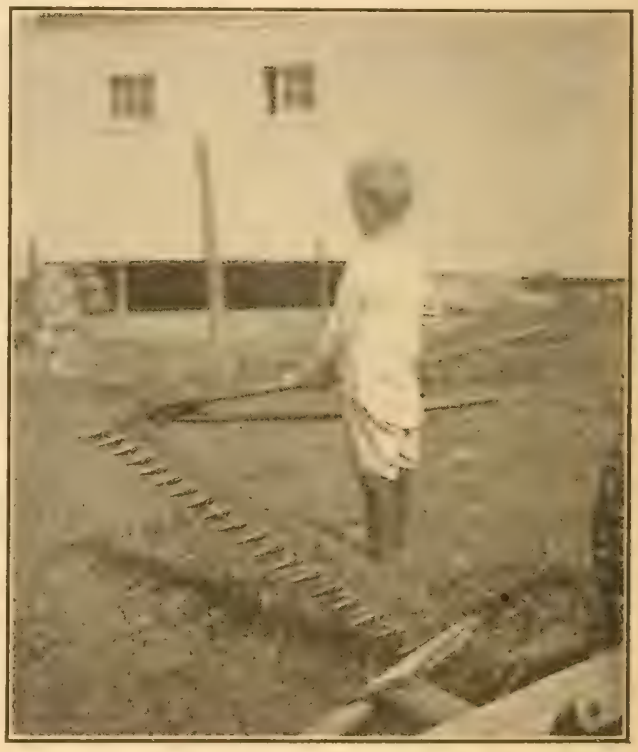

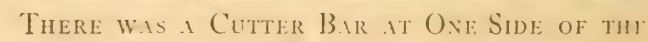
Machine

to make it take hold," said Andy. "You see the wheels are geared to the cutter-bar. When 
they turn they make the bar go back and forth under those points. That's. what cuts off the grass. It's like a row of scissors."

The cutter bar stuck out at one side of the machine. There was a big lever beside the seat. When this was pulled back it made the end of the

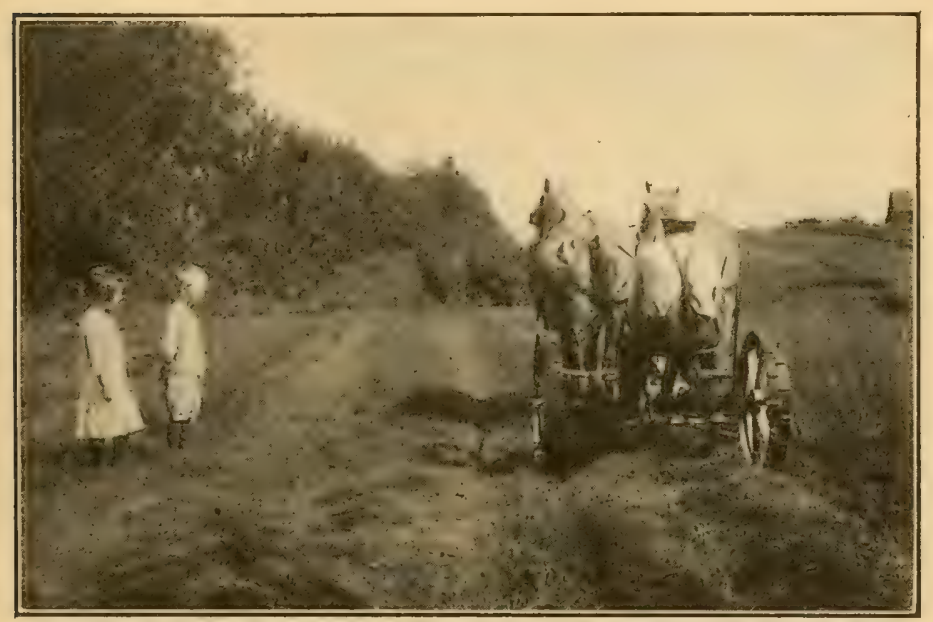

Jim and Peggy Watched the Mower

bar come up. Andy had it raised when he drove out to the field.

Uncle David had an extra team of horses for the day. They were a pair of grays that Mr. Taylor wanted Uncle David to try. So Andy had them hitched to the mower, to see how they'd work.

As soon as the dew had dried on the grass Andy started. He went first around the outside of a 
section of the field. Jim and Peggy stood near the fence and watched him go by. The cutter bar traveled along close to the ground, and the grass fell flat behind it. The machine made a loud noise, like "clack-clack-clack," — only much faster than you could say it. When it was at the farther side of the field Jim and Peggy could still hear it.

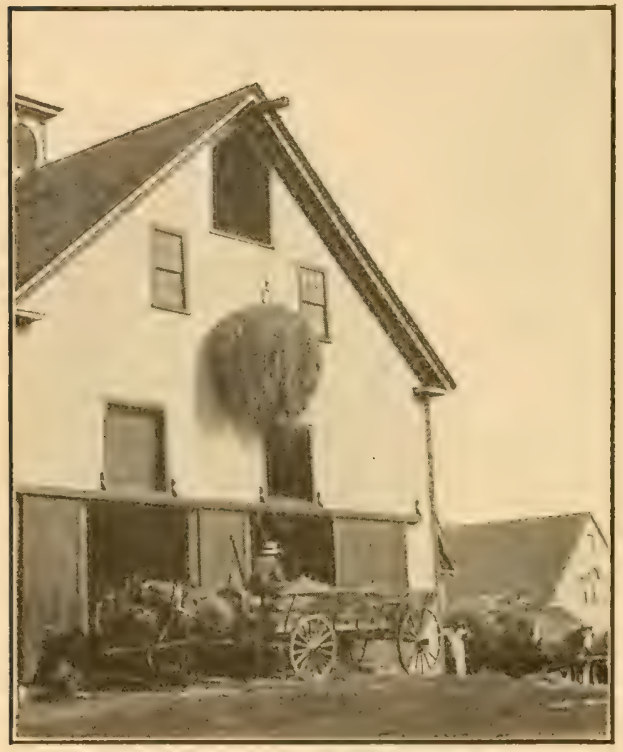

AN Overhead Hay Carrier wis at Work

Andy drove around and around, each time cutting a new strip. The sun was bright and hot. After a while Uncle David came out.

"It's good hayin'weather, Andy," he said. "Looks as if we ought to get this in without any wetting," Andy replied.

"We'll let that lie this afternoon," Uncle David explained to Jim. "To-morrow it ought to be ready to put in the barn."

Uncle John and Aunt Emily were late for dinner. 
They had been out for a walk, they said, up to the top of the hill on the road toward Milford. Uncle David looked at Uncle John, and Uncle John smiled and nodded. Aunt Lucy looked at Aunt Emily, and she smiled and nodded, too.

After dinner Andy hitched Milly to the surrey.

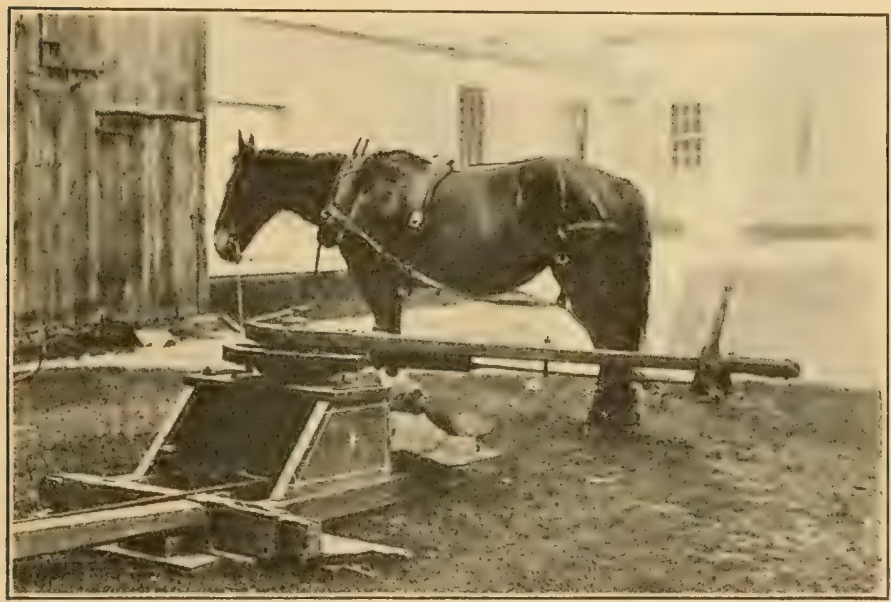

A Horse Went Round and Round

"Uncle David and I are going to drive to Freeport on an errand," said Jim's father. "You and Horace can come along if you want to."

They drove out, along the dusty, sunny road. At nearly every farm a mowing machine was at work. When they couldn't see one they could hear it, somewhere near by.

At some places big loads of hay were being 


\section{JIM AND PEGGY AT MEADOWBROOK}

hauled to the barns. As they passed the Sturtevant farm two men were unloading hay with an overhead carrier. They stopped and watched it work.

The hay wagon was drawn up close to the front of the barn. In the peak of the front, overhead, a big door was open, and above this was a heavy beam. There was an iron track fastened below the beam. A pulley ran on this track.

A rope ran down from the pulley to an iron fork, over the wagon. The man on the wagon jabbed this fork down into the hay in front of him. A horse that stood near the front of the barn walked slowly out, away from the barn, pulling a rope behind him. As he walked a great bunch of hay rose from the wagon until it was opposite the open door overhead, and then disappeared into the barn. In a moment the horse backed up, a man appeared at the door with the fork, empty, and it lowered down to the wagon again.

"You'll see them baling hay at the next place, I think," said Uncle David. "They have some of last year's crop that they're pressing and taking to town."

But they couldn't see much when they got there, for the men were working inside the barn. Just outside the door there was a heavy wooden box, braced to the ground. A pole ran out from the top of the box, and a horse was hitched to the end 
of this. He went round and round the box, drawing the pole after him.

"He furnishes the power to run the baler," said Uncle John. "The machine inside presses the hay into tight, oblong bundles, and the men fasten it

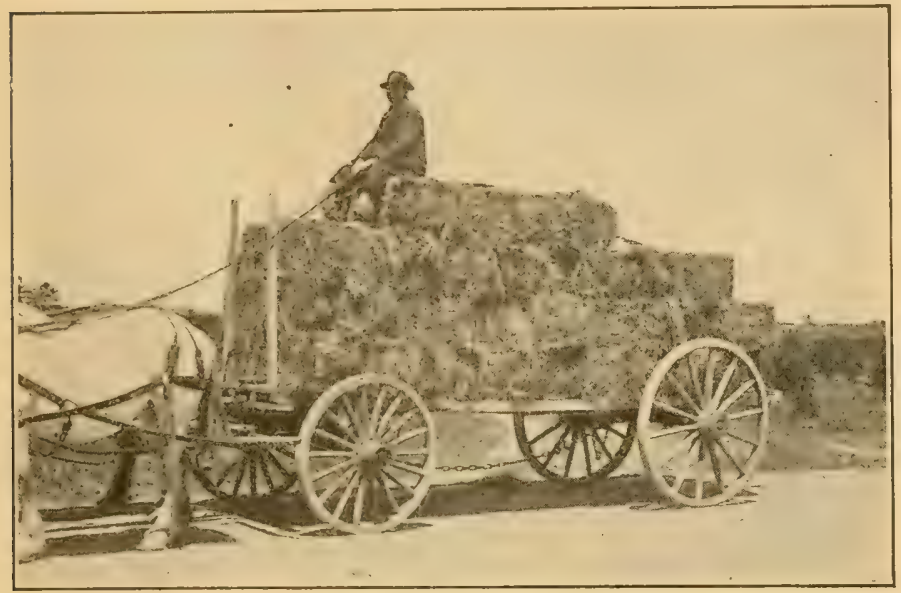

They Saw a Load of Baled Hay

with wires. They do that so that they can ship it on trains."

A little later Jim had a chance to see the hay made up into bales. They passed a load of it, before they reached Freeport.

When they got into town Uncle David drove to a building on the main street. He and Uncle John went up a stairway, and stayed for a long time, while Jim and Horace waited in the surrey. 
It was supper time when they reached home. Aunt Emily came out on the porch as they drove up.

"Did you - ?" she said to Uncle John.

He nodded.

"To-morrow afternoon," he said. 


\section{CHAPTER XXXIV}

\section{THE FARM}

NeXT morning, after the sun was well up, Andy hitched Milly to the hay tedder, and drove up and down the field that they had mowed the day before.

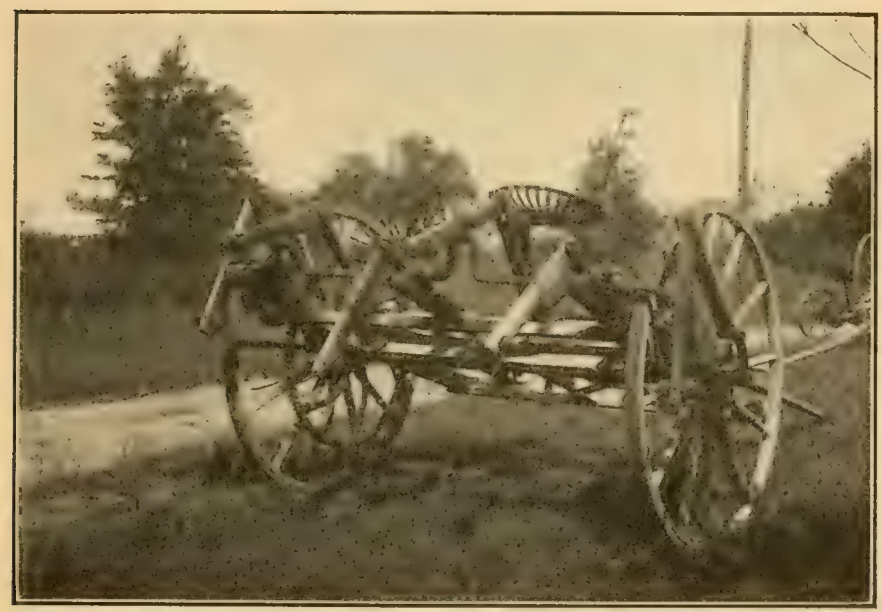

On the Back of the Hay Tedder were Six Forks

It was a funny machine to watch. On the back of it were six forks. As the tedder went along these forks dipped toward the ground, one after another, and then kicked out backward and up- 
ward, tossing the hay into the air. They were like so many legs, each one kicking as fast as it could.

"That's to turn the hay over, and make sure it dries out," explained Andy.

Meanwhile Uncle David drove Dan and Ben to

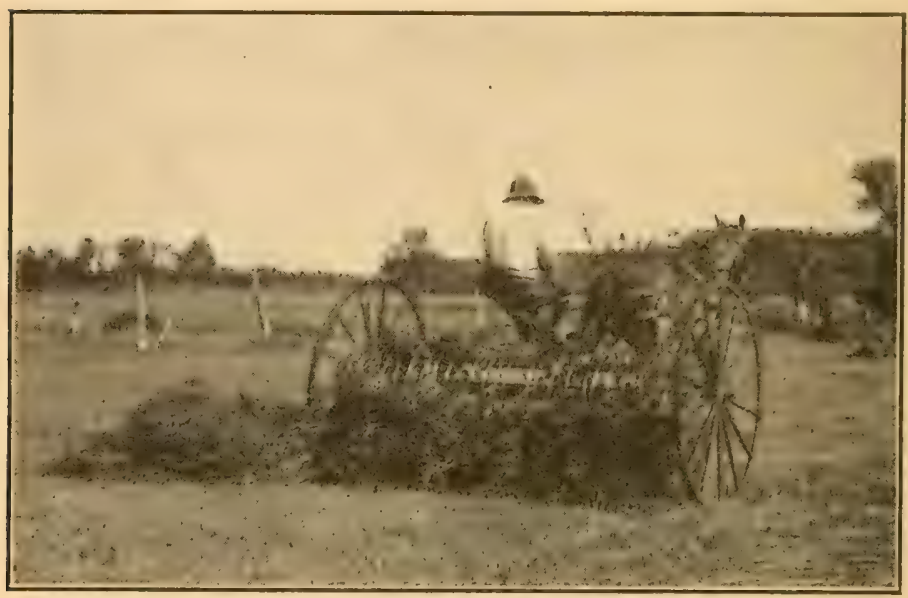

Andy was Driving the Rake

the mowing machine, cutting a new piece, to be ready for another day.

When dinner was over. Uncle John put on his overalls, and the big straw hat.

"I'm going to take a hand this afternoon," he announced.

He and Uncle David went to the barn, with the children trailing along. They got out Dan and 
Ben, and hitched them to a big wagon that had an open rack on it instead of a wagon bed. Uncle David brought out two wide, wooden rakes from the tool room, and put them on the wagon. Then he got two pitchforks, and put them on.

"Jump on, children," he said.

They all climbed on. Peggy and Jane sat on a board in the bottom of the rack. Jim and Horace perched on another board that ran along one side. The men stood at the front end, where there was a narrow frame sticking up, like a short ladder. Bumping and rattling they drove out of the barn.

When they got to the field And y was already there. He was driving Milly, hitched to a rake that

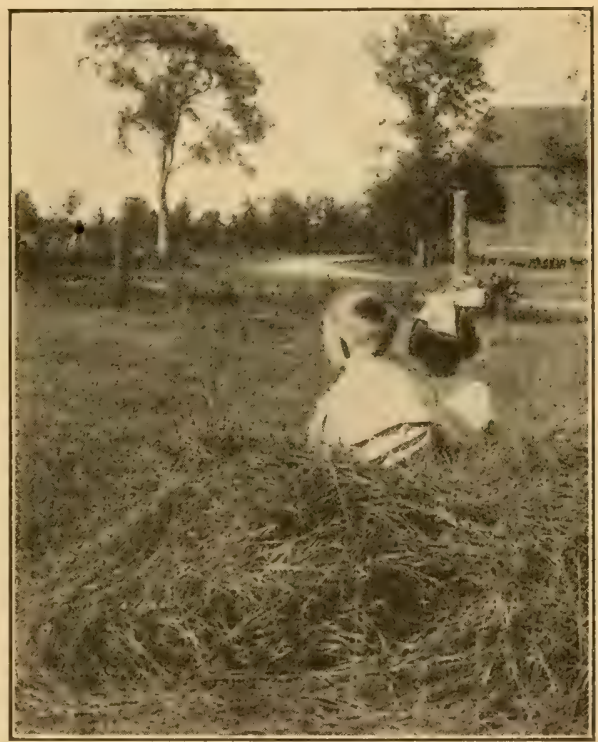

Jim and Peggy Sat on a Pile of Hay

had a wheel at each end, like a buggy wheel, and a seat in the middle for Andy to ride on. As Milly pulled the rake the hay kept gathering in 


\section{JIM AND PEGGY AT MEADOWBROOK}

front of it. Every minute or so Andy would push on a lever, the tines of the rake would rise, and the hay would be left behind in a long heap.

Andy drove and dumped the rake in such way that the heaps of hay were left joining end to end,

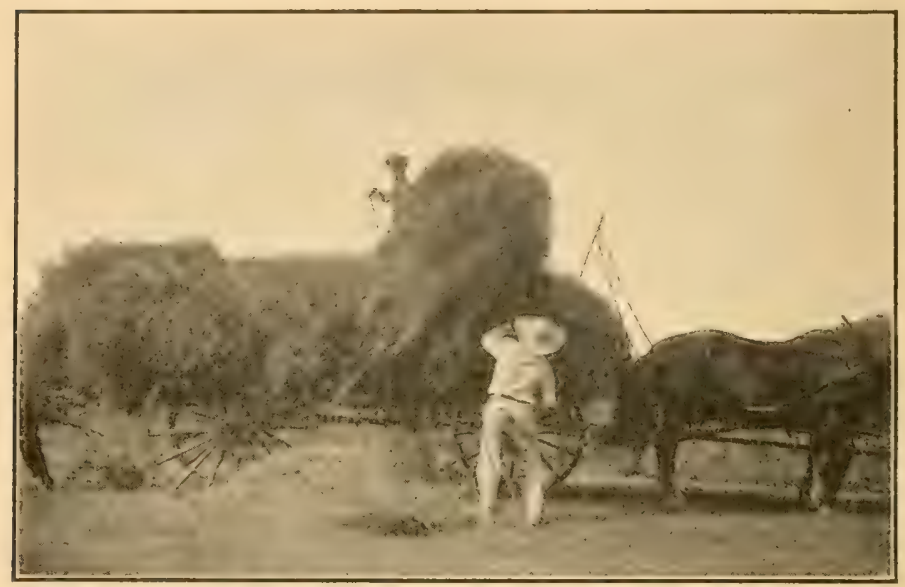

Uncle David and Horace Loaded the Wagon

in a long row. There were many rows, down the field.

Pretty soon Andy turned and drove the other way, lengthwise of a row, dumping the rake every few feet, making the hay into piles. Uncle David started in with a hand-rake, gathering in the hay that had been missed. Uncle John took one of the pitchforks and helped to pile up the heaps.

Uncle David called to Horace and had him drive the wagon close beside one of the piles. Jim and 
Peggy jumped down, and sat on one of the heaps, near by, to watch. Jane stood at the end of the wagon. Each of the men took a fork, and soon had the heap of hay on the wagon. Then Horace drove to the next pile, and so on, to the next one, and the next.

Jane climbed down and joined Jim and Peggy.

After a while the wagon was loaded so high that the men could hardly reach with the forks to put more hay on it.

"Come on," shouted Uncle David.

Jim and Peggy and Jane scrambled up on top,

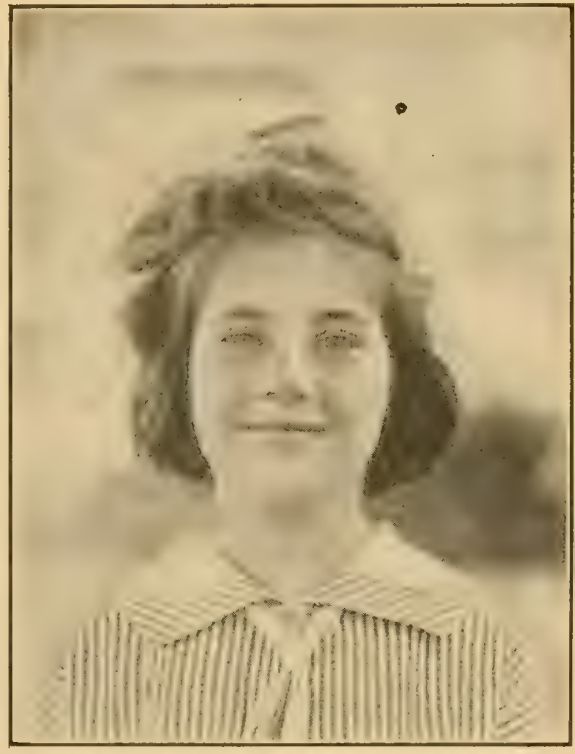

PEGgY with Uncle John helping them. Dan and Ben pulled the load slowly to the farmyard, up the slope, through the big doors, into the barn. Uncle David and Uncle John pitched the hay off into the mow.

'They brought in another load. Andy had 


\section{JIM AND PEGGY AT MEADOWBROOK}

finished raking and had taken Milly to the barn. There were still a few piles left. Uncle David called Andy.

"We won't try to bring in the rest to-night," he said. "Just cap the cocks that are left, and we'll

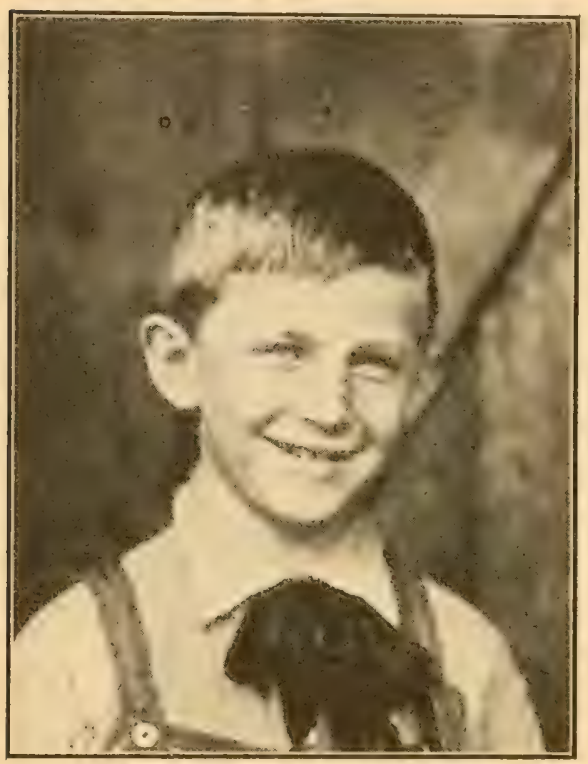

$\mathrm{J} 1 \mathrm{M}$ get it to-morrow."

A little later Uncle David brought Milly out of the barn and hitched her to the surrey. $\mathrm{He}$ and Uncle John got in and drove around to the porch. Aunt Lucy and Aunt Emily came out of the house and joined them. The children were down at the spring. Uncle David called to them.

"We'll be back pretty soon," he said.

"Hannah Wiggin will be over to get supper," added Aunt Lucy.

The evening slipped quickly along. The cows came up through the meadow. Andy went into 
the barn to milk them. Crickets chirped in the grass, Katydids tuned up. Tag whined at the kitchen door for Hannah Wiggin to let him in.

Just before dark the children heard the surrey drive up. They all ran to the porch. Uncle John and Aunt Emily had already got out. Aunt Emily looked at Uncle John and then at the children. She put her arm around Jim and Peggy. "Tell them, John," she said.

"Well," said Uncle John, "you know the farm just beyond the top of the hill, - the one where I lived when I was a boy? We're coming there to live." 

THE following pages contain advertisements of a few of the Macmillan books on kindred subjects. 



\section{EVERYCHILD'S SERIES}

Each Cloth Illustrated $16 m 0$ cents

ALSHOUSE: Heroes of the Nation. For Intermediate and Grammar Grades.

Tales of the heroes of many lands.

ANDERSON: Stories of the Golden Age. For Intermediate Grades.

Legends of the Age of Pericles.

BEMISTER: Indian Legends. For Intermediate Grades,

The life and the traits of character of the American Indian.

BENDER: Great Opera Stories. For Intermediate Grades.

Famous operas told in a simple charming way.

BIRD and

STARLING :

Historical Plays for Children. For Intermediate Grades.

CALHOUN:

CAI.HOUN: When Great Folks Were Little Folks. For Grammar Grades

Plain little bnys and girls who grew up and accomplished great things.

DICKSON: Pioneers and Patriots in American History. For Intermediate Grades.

Our forefathers in the days of the Revolution.

DICKSON: Camp and Trail in Early American History. For Intermediate Grades.

The early discoverers and explorers of our country.

DUNN: What Shall We Play? For Primary and Intermediate Grades.

Dramatizations of a variety of well-known children stories.

FARMER: Boy and Girl Heroes. For Intermediate Grades.

Interesting incidents in the childhood of well-known heroes.

FLETCHER: Old Settler Tales. For Intermediate Grades. Stories of boys and girls in pioneer days.

FROELICHER: A Collection of Swiss Stories. For Primary and Intermediate Grades. Ancient beliefs and historical legends of the Swiss.

GARDNER: Nature Stories. For Primary Grades.

The beauty and usefulness of insects, animals, and flowers told in a way that appeals to the imagination of a child.

\section{THE MACMILLAN COMPANY} 64-66 Fifth Avenue, New York City ATLANTA BOSTON CHICAGO DALLAS SAN FRANCISCO 


\section{EVERYCHILD'S SERIES - Continued}

HALLOCK: In Those Days. For Intermediate Grades. Really true stories of Grandmother's Day.

HOPKINS: The Knight of the Lion. For Intermediate Grades.

A delightful story which preserves the quaint style of the original French.

JAMES: The Building of Cities. For Grammar and Intermediate Grades. A discussion of the building and the growth of cities.

LARGE: A Visit to the Farm. For Intermediate Grades.

The adventures of a city boy who visits his country cousin.

IAARGE: Old Stories for Young Readers. For Primary Grades. A collection of stories which all children ought to read.

OSIVELL: $\quad$ Old Time Tales. For Primary Grades.

Ballads and folktales that children of the Old World have heard for hundreds of years.

OSWELL: A Fairy Book. For Primary Grades.

A collection of good stories of fairies and other little earth people.

OSIVELL: $\quad$ Stories Grandmother Told. For Primary Grades.

Old fairy stories interestingly told.

REYNOLDS: How Man Conquered Nature. For Intermediate Grades. Stories that will give vitality to the study of history and geography.

STOCKTON: Stories ot the Spanish Main. For Grammar Grades.

A collection of stirring adventures on land and sea, portraying scenes of historical and literary value.

UNDER WOOD: Heroes of Conquest and Empire. For Intermediate and Grammar Grades.

Old stories of famous conquerors told with freshness and vigor.

WARNER: Nonsense Dialogues. For Primary Grades.

Mother Goose in dramatic form.

WERTHNER: How Man Makes Markets. For Grammar Grades. The story of commerce.

YOUNG: $\quad$ When We Were Wee. For Intermediate Grades. A vivid picture of child life in war times.

\section{THE MACMILLAN COMPANY}

\section{4-66 Fifth Avenue, New York City}

\section{ATLANTA BOSTON CHICAGO DALLAS SAN FRANCISCO}




\section{THE GOLDEN RULE SERIES}

By E. Hershey Sneath, Ph.D., LL.D., Professor in Yale University; George Hodges, D.D., D.C.L., Dean of the Episcopal Theological School, Cambridge, and Edward Lawrence Stevens, Ph.D., L.H.D., Associate Superintendent of Schools, New York City.

Golden Ladder Book, The. Third Grade.

Cloth. I2mo. xiv +264 pages. 40 cents.

Literature selected and adapted to suggest the correct moral response in affairs within the experience of the child. The home and school virtues are especially emphasized.

Golden Path Book, The. Fourth Grade.

Cloth. I2mo. xiii +280 pages. 45 cents.

Literature selected to cultivate a moral attitude toward life. The simple virtues are dealt with.

Golden Door Book, The. Fifth Grade.

Cloth. I2mo. xiii +308 pages. 50 cents.

Literature selected to illustrate the beauty of right conduct. The community virtues are especially emphasized.

Golden Key Book, The. Sixth Grade.

Cloth. I2mo. xiii +339 pages. 55 cents.

Literature selected for its definite moral appeal to the developing child.

Golden Word Book, The. Seventh Grade.

Cloth. I2mo. xiii +338 pages. 55 cents.

Literature selected to illustrate the simple laws of moral action and reaction. The economic and political virtues receive special consideration.

Golden Deed Book, The. Eighth Grade.

Cloth. I2mo. xiii +35 I pages. 55 cents.

Literature selected for its powerful appeal through noble thought and moral sentiment beautifully expressed.

\section{For Teachers}

\section{Moral Training in the School and Home}

By E. Hershey Sneath, Ph.D., LL.D.; George Hodges, D.D., D.C.L.

Cloth. I2mo, $22 I+x i i$ pages. 80 cents.

Moral instruction through the use of literary selections by the indirect method.

\section{THE MACMILLAN COMPANY}

\section{4-66 Fifth Avenue, New York}

ATLANTA BOSTON CHICAGO DALLAS SAN FRANCISCO 


\section{THE GOLDEN RULE SERIES OF READERS}

\section{READING WITH A MORAL PURPOSE}

\section{A Course of Study in Moral Instruction}

The Golden Rule Series provides the material for a complete and well organized course in moral instruction for elementary schools. This course of instruction is based upon literary selections, appealing in many-sided interest to children. Every selection has been wisely chosen to portray fittingly right action in human conduct and to suggest the correct moral response to situations within the expcrience of the child.

\section{The Material for Moral Instruction}

In making these selections, the anthors have searched the sources of child literature. They have taken the best of the old and of the new. To these selections they have added a well-written group of new stories, introducing Lilly, Betty, and Ben, lovable children, who are developing year by year in moral character. This series teaches the lessons of cleanliness and tidiness, accuracy and thoroughness, self-control and prudence, temperance and self-reliance, obedience and discipline, truthfulness and honesty, love and loyalty. Grade by grade these lessons secure the interests of children.

\section{The Indirect Method of Moral Instruction}

In the volumes of the Golden Rule Series, in the preface, apart from the text, are the suggestions and directions necessary to the successful teaching of moral lessons involved in literary selections. These directions explain the indirect manner of teaching the simple attainable virtues so that the child does his own moralizing.

A helpful discussion of the whole subject of moral instruction by the indirect method, and a systematic and complete course of study that may be used to advantage in connection with the Golden Rule Series is provided in Moral Training in the School and Home, a handbook for teachers.

\section{THE MACMILLAN COMPANY}

\section{4-66 Fifth Avenue, New York}

\section{ATLANTA BOSTON CHICAGO DALLAS SAN FRANCISCO}









\section{LIBRARY OF CONGRESS ||||||||||||||||||||||||||||||||||||||||||||||

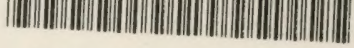 口00ट7487014}

